Augustinus Moravus Olomucensis 



\section{Augustinus Moravus Olomucensis}

Proceedings of the International Symposium to Mark the $500^{\text {th }}$ Anniversary of the Death of Augustinus Moravus Olomucensis (1467-1513)

$13^{\text {th }}$ November 2013,

National Széchényi Library, Budapest

Edited by

Péter Ekler and Farkas Gábor Kiss
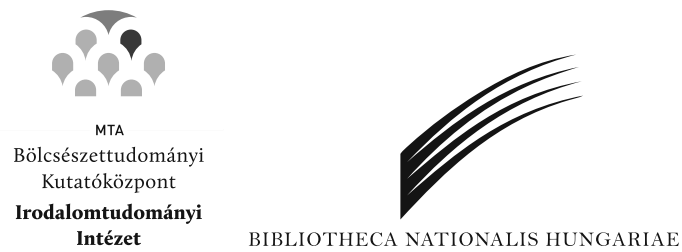

Institute for Literary Studies, Research Centre for the Humanities, Hungarian Academy of Sciences - National Széchényi Library

Budapest, 2015 


\section{Supported by \\ n<a \\ Nemzeti Kulturális Alap}

NKA Szépirodalom és Ismeretterjesztés Kollégiuma (3808/01609)

NKA Könyvkiadás Kollégiuma (3437/01449)

Institute for Literary Studies, Research Centre for the Humanities,

Hungarian Academy of Sciences

National Széchényi Library

MTA-ELTE Research Group on Humanism in East Central Europe

OTKA PD-104316

János Bolyai Research Scholarship of the Hungarian Academy of Sciences

(BO/00177/13/1)

Editors: Péter Ekler and Farkas Gábor Kiss

Editors of the Bibliography: Péter Ekler and Enikő Békés (assistant editor)

Index prepared by Krisztina K. Kaposi

Notes to the poems and the Panegyricus: Farkas Gábor Kiss and Péter Ekler

Language editors: Eszter Timár [English], Theresa Rothfuß [German],

Valerio Sanzotta [Italian]

Executive publishers: Gábor Kecskeméti and László Tüske

Cover page: Meeting of Augustinus (sitting) and Laelius (standing) near Padua.

Apologia poetarum, Berlin, St. Bibl., ms. lat. fol. 335, $9^{\text {r }}$

ISBN 978-963-200-636-9

Published by the

Institute for Literary Studies, Research Centre for the Humanities,

Hungarian Academy of Sciences

National Széchényi Library

Design: Imre Horváth

Prepress preparation: Institute for History, Research Centre for the Humanities,

Hungarian Academy of Sciences

Printed: Prime Rate Kft. 


\section{Contents}

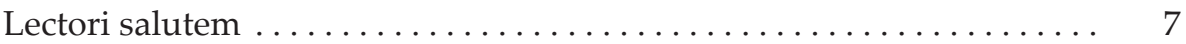

Editors' Preface and Acknowledgements .................. 9

Christian Gastgeber

Augustinus Moravus und seine Beziehungen zum Wiener

Humanistenkreis

Anna Rose

„Natio germanica“ der Bologneser Universität und

ausländische Studenten von Filippo Beroaldo dem Älteren ....... .

Matyáš Franciszek Bajger

Discovering Relationships

between Jan Filipec and Humanism ............... 45

Eмốke Rita Szilágyi

Johannes Roth und Augustinus Moravus Olomucensis . . . . . . . . . 61

ZoLtÁn CseHY

Augustinus noster: Augustinus Olomucensis nella poesia

di Bohuslaus Hassensteinius $\ldots \ldots \ldots \ldots \ldots \ldots \ldots \ldots$

FARKAS GÁBOr Kiss

Augustinus Moravus and the Transmission

of Ancient Wisdom in the Context of Poetry . . . . . . . . . 77

ÁdÁm SMrCZ

The Portrait of Bassareus Medicus (Conrad Celtis

and Augustinus Moravus) $\ldots \ldots \ldots \ldots \ldots \ldots \ldots \ldots . \ldots . \ldots . \ldots$

Péter EKLer

Augustinus Moravus's De modo epistolandi . . . . . . . . . . . . . . . 101

EDINA ZsUpÁN

Bessarion immer noch in Buda? Zur Geburt

der Bibliotheca Corvina ............................ 113 
Jana KoláŘová

Latin Poems Dedicated to Stanislaus Thurzo,

Bishop of Olomouc

Lucie Storchová

The "Apostle" of Renaissance Humanism in Moravia? . . . . . . . . 149

Appendix ONE

Poems by Augustinus Moravus Olomucensis . . . . . . . . . . . . . . 157

Appendix two

Valentin Eck's Panegyricus in Honour of Augustinus Moravus

Olomucensis

ApPendix THREE

Augustinus Moravus Olomucensis (1467-1513).

Selected Bibliography....................... 183

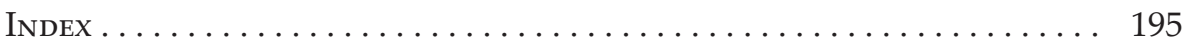

Illustrations ................................... 205

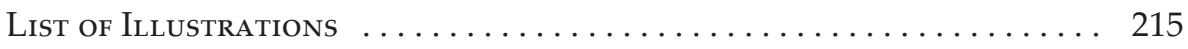

Authors and their Affiliations . . . . . . . . . . . . . . 216 


\section{Lectori salutem}

The study of Central European Humanism of the early modern period has been actuating for a long time the cooperation of the Bohemian, Moravian, and Hungarian scholars. Their joined efforts never ceased, not even during the most difficult decades of the $20^{\text {th }}$ century. Bohumil Ryba, professor at Charles University, in Prague, had just finished the edition of a fifteenth century Latin dissertation written by Iohannes Rabensteinensis, the offspring of a Bohemian noble family, before the critical times of September 1942. The booklet was published in the much acclaimed Bibliotheca Scriptorum Medii Recentisque Aevorum, a famous book series that was established by the Hungarian scholar, László Juhász, during his years at Szeged University. By this time, the common undertakings of the Bohemian and the Hungarian scholars had steadily been developed; while Ryba published a few of the humanist Bohuslav Hasištejnský z Lobkovic's writings in the aforementioned book series in 1937, it was Juhász who, after having closely collaborated with Augustin Potuček for years, published Lobkovic's letters in 1946, ulterior to Potuček's passing. Moreover, the publication of Stephanus Taurinus Olomucensis's Stauromachia in 1944, was Juhász's personal enterprise.

There came the grievous subjection of both Czechoslovakia and Hungary during the ensuing decades of the Second World War. Professor Ryba, for instance, was deprived of his Academician title, given a show trial and sentenced to long prison term. Despite this abjection, there had always been someone who kept alive the scholarly interest for the Bohemian-Hungarian cultural contacts of the Renaissance and Baroque period. They were the Hungarians Endre Angyal, László Dobossy, Endre Kovács, or the Bohemian Richard Pražák, just to mention but a few. Furthermore, Juhász's acknowledged book series, the Bibliotheca Scriptorum Medii Recentisque Aevorum was relaunched by Tibor Klaniczay at the Institute for Literary Studies of the Hungarian Academy of Sciences, in 1976. Naturally, the new series could not be sustained without the publishing of humanist texts originating from Bohemia, thus Dana Martínková edited the 1563 travelogue written in France by the České Budějovice born Simon Proxenus a Sudetis, relying on the manuscript preserved in Brno.

The Bibliotheca, undertaking the critical edition and publication of early modern Latin texts, is still being edited at the Institute for Literary Studies of the Hungarian Academy of Sciences. It is our institute that hosts that restricted 
scholarly community whose members are committed to the complex and exhaustive study of the regional particularities of Central European Humanism. The conference in November 2013, organized by joint efforts of our institute and National Széchényi Library, constituted the very first opportunity to posit the oeuvre of Augustinus Moravus Olomucensis in the very centre of scholarly attention, though this body of humanist texts has long ago challenged our interest embedded in the prevailing intellectual context of the Bohemian, Moravian, and Hungarian Humanism.

Nowadays, when finally the Central European region ceased to be dominated by decades of cataclysms, a research investigating the history of the region's Latin philological culture will surely reveal new perspectives on collaboration. For, I believe, it was this conference that testified for these new possibilities of further scholarly enterprises; besides, it was an excellent occasion to salute the experts in the relevant fields and the learned contributors of this event. It is an extraordinary pleasure to have the opportunity of greeting the collection edited from the papers of this unique conference.

Gábor Kecskeméti director of the Institute for Literary Studies, $\mathrm{RCH}$, Hungarian Academy of Sciences 


\title{
Editors' Preface and Acknowledgements
}

\begin{abstract}
"Quando arrivò in Ungheria aveva già alle spalle una significativa produzione scientifica: oltre ad alcuni trattati di astronomia, durante il suo soggiorno a Padova aveva infatti scritto - per poi publicarli a Venezia - anche il Dialogus in defensionem poetices (1493) e il De modo epistolandi (1495), libelli non privi di interesse dal punto di vista della cultura letteraria e che furono sicuramente letti a Buda dagli amici di Augustinus [Moravus Olomucensis]. La ricerca ungherese, perciò, dovrebbe finalmente tenerli in debita attenzione." $^{1}$
\end{abstract}

The internationally renowned scholar, Tibor Klaniczay (1923-1992) and his words about Augustinus Moravus, published in Hungarian in 1993 (posthumously!), encouraged us to conduct further research into his lifework. ${ }^{2}$ (The Italian translation of the book has come out recently.)

The motivation for the international conference the present volume is based on was the $500^{\text {th }}$ anniversary of Augustinus Moravus's death. The organisation of the 2013 conference was kindly supported by Marta Vaculínová, Petr Mat'a and Christian Gastgeber, who also provided us with useful information concerning Augustinus Moravus.

We would like to thank numerous individuals, who helped us in organizing this conference, including Ernő Marosi, who acted as chair. We are also highly grateful for the professional advice provided by István Monok, Árpád Mikó and László Boka. We also acknowledge with gratitude the support of Director Gábor Kecskeméti (Institute for Literary Studies, Research Centre for the Humanities, Hungarian Academy of Sciences) and DirectorsGeneral Péter Szemerei and László Tüske (National Széchényi Library) in organising the conference and issuing the present volume.

We appreciate the generous contribution of the collections that have made available the digital copies of images in the volume. Among the illustrations on the cover page and at the end of the volume, we have featured

1 Tibor Klaniczay, Alle origini del movimento accademico ungherese. A cura di Amedeo Di Francesco, Judit Papp, Orsolya Száraz. Presentazione di István Monok. Premessa di Amedeo Di Francesco (Alessandria: Edizioni dell'Orso, 2010), 89.

2 Tibor Klaniczay, A magyarországi akadémiai mozgalom előtörténete (Budapest: Balassi, 1993), 63. 
copies of the manuscript marked as Ms. lat. fol. 335 in the Staatsbibliothek zu Berlin - Preußischer Kulturbesitz (SBB-PK), for which we are obliged. We can only hope that the indistinct features of Augustinus Moravus as we see him in the contemporary painting of Peter Vischer the Younger (see on our coverpage) will become clearer and sharper with the publication of these studies.

Special thanks are also expressed to the Wrocław Ossolineum (Dział Starych Druków, Zakład Narodowy im. Ossolińskich, Wrocław) for providing the National Széchényi Library with a photocopy of the Panegyricus in laudem praestantissimi viri doctoris Augustini Moravi (XVI. Qu. 3593) free of charge and for giving permission for publishing the full text.

We are equally indebted to the Dresden collection (Staatliche Kunstsammlungen Dresden, Grünes Gewölbe) for providing the volume with free images of the golden bowl (Inv. Nr. IV/ 40).

We also owe our sincere thanks for the invaluable support of our own employers and the following institutions: Institute for Literary Studies, Research Centre for the Humanities, Hungarian Academy of Sciences; National Széchényi Library; National Cultural Fund of Hungary (NKA); Eötvös Loránd University; Research Centre for the Humanities, Hungarian Academy of Sciences; MTA-ELTE Research Group on Humanism in East Central Europe; Hungarian Scientific Research Fund (OTKA); Bolyai János Research Scholarship.

Our undertaking was helped by important information and data given by Marta Vaculínová, Milada Studničková, Simona Kolmanová, Enikő Békés, Eszter Kovács, John Monfasani, Roman Mazurkiewicz, Michael Moser, Harald Bollbuck, Ivo Hlobil, Petr Elbel, Petr Mata, Kamil Boldan, Martin Svatoš, Štěpán Kohout, Antonín Kalous, Jiří Just, Jan Pišna, Jiří Kubes, Jakub Žytek, Jindřich Marek, Tamás Adamik, István Bartók, István Monok, Kornél Szovák, László Takács, András Zoltán, Árpád Mikó, Barnabás Guitman, Tamás Fedeles, Richárd Horváth, Tibor Neumann, Péter Kasza, János Véber, Farkas Gábor Farkas.

It is our hope that the present volume will give new impetus to all those who wish to do further research into the field.

$13^{\text {th }}$ April 2015, Budapest

Péter Ekler and Farkas Gábor Kiss 


\section{Augustinus Moravus und seine Beziehungen zum Wiener Humanistenkreis}

Die Beziehung des Augustinus Moravus ${ }^{1}$, selbst Mitglied der Sodalitas litteraria Danubiana, an der Wende vom 15. zum 16. Jahrhundert zu den Wiener Humanisten steht in Verbindung mit dem neu berufenen Wiener Professor Konrad Celtis (1497-1508) und einer Fokussierung der Drucklegung seiner Werke in Wien. Auch zu Celtis' humanistisch gesinnten Zeitgenossen in Wien zeigen sich enge Beziehungen, wie Paratexte seiner Wiener Veröffentlichungen bezeugen. Die wenigen Dokumente dieser Kontakte fügen zugleich weitere Mosaiksteinchen dem Bild des frühen Wiener Griechischhumanismus hinzu.

\section{Augustinus Moravus und Konrad Celtis}

Der Kontakt zu Celtis setzt nach seiner Berufung nach Wien (7. März 1497) ein. Dokumentiert ist diese Ankunft auch durch einige Begrüßungsgedichte der Sodalitas litteraria Danubiana, deren Gründung auf seine Initiative ${ }^{2}$ zurückging (Herbst 1497). Unter den Autoren ${ }^{3}$ hat sich auch Augustinus als $\operatorname{Re}$ (gis) Pan(noniae) Sec(retarius) mit einem Epigramm eingefunden (Abb. 1):

1 Zur Person siehe Ralf G. Czapla, "Augustinus Moravus", in Deutscher Humanismus 1480-1520. Verfasserlexikon, Bd. 1, A-K, herausgegeben von Franz Josef Worstbrock (Berlin, New York: De Gruyter, 2008), 61-72.

2 Vgl. Moritz Csáky, „Die ,Sodalitas litteraria Danubiana'. Historische Realität oder poetische Fiktion des Conrad Celtis?," in Die österreichische Literatur. Ihr Profil von den Anfängen im Mittelalter bis ins 18. Jahrhundert, Teil 2, herausgegeben von Herbert Zeman (Graz: ADEVA, 1986), 739-758.

3 Iohannes Krachenberger, Iulius Milius (Aemilius), Iohannes Cuspinianus, Andreas Stiborius, Iohannes Stabius, Christoforus de Waitmyl (Weitmühl), Sturlinius Smalcaldia (Iohannes Sturnus), Hieronymus Balbus, Bartholomeus Scipio (Stäber), Iohannes Slechta, Georgius Neydecker (Georg von Neideck), Erasmus Pinifer (Beck), Iohannes Tolophus (Tolhopf), Theodoricus (Dietrich) Ulsenius, Henricus Cuspidius (Spieß), Francesco und Pietro Bonomo. Texte in: Der Briefwechsel des Konrad Celtis, gesammelt, herausgegeben und erläutert von Hans Rupprich, Veröffentlichungen der Kommission zur Erforschung der Geschichte der Reformation und Gegenreformation, Humanistenbriefe, III. Bd. (München: C. H. Beck, 1934), 299-306. (Nr. 180). 
Celtis Pegaseas sacro ex Helycone Camenas

Vexit ad Austriaci rura beata soli.

Salve igitur, Phoebi criniti sancte sacerdos,

Celtis, Germanae gloria rara togae,

Et vos, laurigerae, cultissima turba, sorores,

Tu quoque inaurata, pulcher Apollo, lyra.

Quae vobis genitus Morava gente poeta

Carmina dat, tenui sint licet orsa modo,

Perpetui, quaeso, sint vobis pignus amoris.

Haec sint parva licet, mens pia magna fecit. ${ }^{4}$

\section{Epifodia Sodalítatis líttcrarie 物anubiane ad Conradũ Celten oum a nozico gymnafio ad Z̈ Ciennam 1Damnonie concelferat.}

C Joannes Braccus pierius TRo.tRe. Scẽ

Celtis adeft:Leltis clariy rotaipima triumpli Sentís germane glozía celtis adeft

sed non folus adeft facre pia turba forozes 1Pars idem remo:pars pede carpit iter

Letadíes albo nun Accipecadentis lactedifigna note

Spumet odozato críftallus aquofa pbalerno Zraturob facrís laurea vírga focis

In pzimis merito pbebo reddant bonozes Thborfigero fiant pzorima facra oco

Bbec queos piería pafim vor perfonct aula aDsufaru celtis f́pefos decufós venit.

CEluguitinus Olomocenfis iRe, TPań. Ecer.

Leltis pegafeas facro er belycone camenas Gerit ao anftriaci rura bcata folí

Salue igit plebi crimiti fancte facerdos Lel tis germane glozia rara toge

Et vos latrigere cultifima turba fozozes In 1 ínaurata pulcber apollo lyra

Que vobis genitus mozaua gente poet carmina dat tenui fint licet orfa modo
-Pcrpetui ãfo fint vobis pignus amoris becfint pualicet més pia magna facít. C Julus âsilius?Re. iDañ. TD bificus. Quũ tot carmibus quĩ tot celebzere poetis Thon opus eft verfu celti oífertemeo If un के caftalios baufi oe fonteliquores Ubera pima licet melpomene dederat

OJ cernés p beb?,medícas me vertít ad artes Et rerúcaufasnofcere poffe oedit

Et oíxít oulces feq̃ris curiule camenas Iltera oebetru laurea népe tibí

Lura erit ifta tibíreges fernare potêtes Iftc illís medicas exbibuifie manus

TParceigit quefo nobis ooctifíme cclti Si pbeb? negat boc qơ me' ardorbabz

Thunc auguftínus vatcs clarifimus ille Deferibat landes celti oiferte tuas

Sc3 vtmufas ad ripas oureris biftri Et fis germani glozia prima folí

Zluftría qo ooctas p te oat clara poctas Zt timiles lacio ví rear efle meo

Abb. 1: Epigramme der Sodalitas litteraria Danubiana zur Ankunft des Konrad Celtis in Wien 1497; die Gedicht sind gedruckt als Vorspann der Lucii Apulei Platonici et Aristotelici philosophi epitoma divinum de mundo seu cosmographia ductu Conradi Celtis, Wien: Iohannes Winterburg [1497], [f. A ir]

Kurze Zeit darauf, am 1. November 1497, wendet sich Augustinus aus Buda an Celtis mit einem Vorwurf ${ }^{5}$ : Celtis wollte Augustinus schreiben und

4 Rupprich, Briefwechsel, 301. (Nr. 180). Quelle: Lucii Apulei Platonici et Aristotelici philosophi epitoma divinum de mundo seu cosmographia ductu Conradi Celtis, impressum Vienne: Iohannes Winterburg (nicht vor 1. Nov. 1497) (GW 2424/10N; ÖNB-Ink A-406); vgl. dazu Gedeon Borsa, „Wiener Typenmaterial zu Anfang des 16. Jhs. im Maingebiet," Gutenberg-Jahrbuch 1966: 26-28.

5 Jenő Ábel, „Magyarországi humanisták és a dunai tudós társaság,“ Értekezések a Magyar Tudományos Akadémia Nyelv-és Széptudományi Osztálya köréból VIII 8 (Budapest: Magyar Tudományos Akadémia, 1880): 110-111. (Nr. 1); verbesserte Ausgabe bei Rupprich, Briefwechsel, 308. (Nr. 181). - Der Briefwechsel mit Celtis ist im Briefcorpus von der Hand des Iohannes Rosenberger, Celtis' Sekretär, in Codex 3448 der Österreichischen Nationalbibliothek erhalten. 
hat dieses Versprechen - wie auch Hieronymus Balbus ${ }^{6}$ - bislang nicht eingelöst. Er erwartet sich, dass beide unter Berücksichtigung ihrer amicitia ihr entsprechendes officium erfüllen und aus ihrer officina etwas erstatten. Dann sei auch die zeitliche Verzögerung zu verzeihen. Das Schreiben, das bereits durch die Betonung der amicitia und die Anrede mi Conrade enge Vertrautheit zeigt, endet mit einem Gruß von Iulius Milius ${ }^{7}$.

Die Sodalitas litteraria Danubiana ladet Celtis am 8. Dezember $1497 \mathrm{zu}$ einem Besuch nach Buda ein ${ }^{8}$. Das Schreiben ist von hoher Wertschätzung und tiefer Bindung der Budaer Gelehrten Celtis gegenüber geprägt ${ }^{9}$. Ein paar Tage später, am 17. Dezember 1497, bittet Augustinus Celtis um die Rückgabe einer noch nicht überarbeiten Version seiner Erotica ${ }^{10}$. Diese habe er Hieronymus Balbus übersandt, doch hatte jener sie in Wien bei seiner Rückreise nach Ungarn bei Celtis gelassen. Zugleich erbittet Augustinus auch ein opusculum des Celtis; dessen Slesia sei noch beim cosmographus, der in einem Brief Augustins vom 5. März 1498 als geographus regius ${ }^{11}$ bzw. in einem Schreiben des Iohannes Schlechta (Jan Šlechta ze Všehrd, 1466-1525) aus Buda vom 26. April 1498 als Philippus, cosmographus noster ${ }^{12}$ näher bezeichnet wird. Danach tritt eine kurze Pause in der Korrespondenz ein, die Augustinus am 5. März 1498 beklagt $^{13}$. So schnell habe Celtis (wie auch Balbus) schon wieder die neue Freundschaft vergessen. Augustinus lässt gerade noch eine Gicht als Entschuldigung gelten, so dass die Schreibfeder nicht bewegt werden kann ${ }^{14}$. Augustinus will aber nicht aufhören, Celtis so lange zu kontaktieren, bis jener selbst unwillig ein Gedicht oder einen Brief schickt. Celtis' Slesia schickt er jenem wieder zurück; der (oben schon erwähnte) Hofgeograph (Philippus) sei damit nicht ganz einverstanden. Augustinus erbittet sodann Celtis' Epigrammata oder zumindest sein jüngst über Germania ${ }^{15}$ verfasstes. Augustins eigene Gedicht (vermutlich die am 17. Dezember 1497 erwähnten Erotica) hat Celtis inzwischen wohl gelesen; es wird noch einmal betont, dass dies eine

6 Zur Biographie siehe Elisabeth Klecker, „Hieronymus Balbus,“ in Deutscher Humanismus 1480-1520. Verfasserlexikon 1, 109-115.

7 Ein Mitglied der Sodalitas Litteraria Danubiana; er begrüßt Celtis 1497 ebenfalls mit Distichen und wird im Titel als Reg(is) Pan(noniae) Phisicus bezeichnet (s. Anm. 3).

8 Rupprich, Briefwechsel, 310. (Nr. 183).

9 "Quam ardenti desiderio vultum et praesentiam tuam videre cupimus, Celtis charissime, non est in promptu dicere: certe inprimis cum ob ingenii et doctrinae tuae amplitudinem, tum ob tuam in nos singularem affectionem" (Rupprich, Briefwechsel, 310, Z. 4-7).

10 Ábel, Magyarországi humanisták, 111. (Nr. 2); Rupprich, Briefwechsel, 311. (Nr. 184).

11 Ábel, Magyarországi humanisták, 111. (Nr. 3; Ábel liest Icographus, führt aber die verbesserte Form cosmographus an); Rupprich, Briefwechsel, 318, Z. 13. (Nr. 189).

12 Ábel, Magyarországi humanisták, 117. (Nr. 12); Rupprich, Briefwechsel, 330, Z. 11. (Nr. 198).

13 Ábel, Magyarországi humanisták, 111-112. (Nr. 3); Rupprich, Briefwechsel, 318. (Nr. 189).

14 En passant ein Hinweis, dass man persönlich die Briefe schrieb und nicht diktieren ließ.

15 Gemeint ist die nie erschienene Germania illustrata. Siehe dazu Gernot Michael Müller, Die »Germania generalis« des Conrad Celtis. Studien mit Edition, Übersetzung und Kommentar, Frühe Neuzeit, Bd. 67 (Tübingen: Max Niemeyer Verlag, 2001), 441-484. 
unredigierte Version sei, doch einem Freund wolle er nichts verheimlichen. Balbus solle sie aber mit Augustins carmen heroicum zur erstbesten Zeit nach Buda zurückschicken; dazu soll Letzteren Celtis auffordern.

Augustinus, der selbst seine Studien in Padua und Ferrara mit einem Doktorat im kanonischen Recht abgeschlossen hat und dort direkt mit dem italienischen Humanismus in Kontakt kam, während Celtis ja nur einen schnellen giro d'Italia 1487 mit Stationen Rom, Florenz, Bologna, Ferrara, Padua und Venedig ${ }^{16}$ absolvierte, konnte sich auch mit der griechischen Sprache vertraut machen. Celtis zeigte darin hingegen nur sehr rudimentäre Kenntnisse, betonte dennoch gerne seine diesbezügliche Sprachgewandtheit ${ }^{17}$. Inzwischen war offensichtlich auch in Buda bekannt geworden, dass sich Celtis um die Etablierung von Griechischstudien in Wien bemühte. Augustinus beglückwünscht Celtis dazu am 29. März $1498^{18}$. Celtis habe damit die Graecae litterae gleichsam post limina „restituiert“. Er begrüßt dazu ausdrücklich Celtis' Plan, Venedig zwecks caracteres Graecae aufzusuchen, also auch den Griechischdruck in Wien zu forcieren. Augustinus empfiehlt dazu in der Lagunenstadt Markantonio Sabellico oder Giorgio Valla. Bei der Reise nach Italien solle Celtis gleich nach neuen Publikationen Ausschau halten, vor allem bei denjenigen Werken, die hier bei ihnen nur fragmentarisch oder im Text verdorben erhalten sind. Celtis möge auch die libelli Augustins mit einem Ausonius durch Gregorius, den Neffen „unseres“ Herren, wieder zurückgeben.

Etwa zwei Jahre später, am 29. Jänner 1500, ist Augustins carmen heroicum druckfertig ${ }^{19}$; Iohannes Krachenberg wird Celtis dieses mit seinen Elegien überbringen. Celtis möge dafür Sorge tragen, dass der Drucker nichts verändert oder verfälscht. Celtis dürfe für diesen Freundschaftsdienst eine Gegengabe erwarten.

Über vier Jahre ist kein Zeugnis eines Briefwechsels erhalten; Augustinus hat unterdessen ein non vulgare quoddam sacerdotium ${ }^{20}$ erhalten; dies erfordert von ihm jedoch auch die Beseitigung möglicher Angriffspunkte seiner Person, so schreibt Augustinus am 23. August 1504 Celtis über seine diesbezüglichen Sorgen: timeo tamen interea curtisanorum quorundam praestigias, qui livore et invidia ducti mihi propalam insidiantur retiaque et tendicula adversum me nonnulla, ut audio, struunt. ${ }^{21}$ Celtis solle daher aus Augustins facetiae zwei Gedichte (?) til-

16 Siehe dazu Jörg Robert, "Celtis, Konrad," in Deutscher Humanismus 1480-1520. Verfasserlexikon 1, 375-427, bes. 377. Zu Moravus' Bildungsweg siehe Czapla, Augustinus Moravus, 62.

17 Vgl. Christian Gastgeber, „Die Erschließung neuer Quellen. Der Zugang zum Griechischen im Wiener Humanismus," in Artes - Artisten - Wissenschaft. Die Universität Wien in Spätmittelalter und Humanismus, herausgegeben von Thomas Maisel, Meta Niederkorn-Bruck, Christian Gastgeber, Elisabeth Klecker, Singularia Vindobonensia 4 (Wien: Präsens Verlag, 2015), 127-198.

18 Ábel, Magyarországi humanisták, 112. (Nr. 4); Rupprich, Briefwechsel, 322. (Nr. 192).

19 Ábel, Magyarországi humanisták, 112-113. (Nr. 5); Rupprich, Briefwechsel, 386-387. (Nr. 231).

20 Ábel, Magyarországi humanisták, 114. (Nr. 8); Rupprich, Briefwechsel, 566, Z. 1. (Nr. 313).

21 Ábel, Magyarországi humanisták, 114. (Nr. 8); Rupprich, Briefwechsel, 566, Z. 2-6. (Nr. 313). Ein bekannter Widersacher war Konrad Weidmann, der 1498 bei der Wahl des Dompropstes von 
gen, und zwar de titulis cardinalium und de summo pontifice. Er gibt hier noch einen weiteren Einblick in das intrigante Hofleben: Nosti enim mures palatinos, quam vafri sint ad aucupanda beneficia quamque me facile vel crimine laesae maiestatis reum arguere possint vel agere mecum ex iure manu consertum. ${ }^{22}$ Celtis möge Augustinus daher nicht der Gefahr dieser Ungebildeten aussetzen; er selbst wartet auf Celtis' versprochenes Auri et Priapi de eminentia certamen ${ }^{23}$. Diese Bitte der Tilgung anstößiger Gedichte wiederholt Augustinus am 12. September 1504 noch einmal in aller Eindringlichkeit ${ }^{24}$. Man könnte ihn ernsthaft anklagen, und seine sacerdotia könnten von Rom neu verteilt werden. Den Rest der facetiae möge Celtis durchaus in Druck geben. Erneut wird Celtis' Priapi cum Auro certamen erbeten. Dieses Schreiben drückt zugleich auch Augustins Dank für Celtis' Einbeziehung von Mähren in Letzteres geographisches Werk aus. So hielt sich Celtis erst unlängst in Olmütz auf, wie Augustinus von den concanonici erfahren hat; denn er beschränke sich nicht nur auf die Germania (illustrata), sondern beziehe auch Mähren mit ein, ubi Augustini tui tibi semper deditissimi incunabula nosti ${ }^{25}$.

Die folgenden erhaltenen Briefen zeigen im Ton einen gewissen Schwenk: Nun steht (inszenierte?) Kritik viel mehr im Vordergrund. Am 30. November 1504 verhöhnt Augustinus Celtis' triumphus de Boemis und dessen Aufführung in Wien comico choragio ac syrmate aus Anlass des Sieges Kaiser Maximilians I. über eine böhmische Söldnergruppe (im Gefolge der Wittelsbacher) am 12. September 1504 bei Wenzenbach, nahe Regensburg ${ }^{26}$. Einen solchen ungleichen Sieg von 14.000 deutschen Panzerreitern gegen 1000 böhmische Fußsoldaten mit Schildbewaffnung verherrliche man nicht in klassisch epischer Form. Er bittet jedoch um Zusendung pugnae huius ludicrum, womit das folgende Werk gemeint: Divo Maximiliano Augusto Chunradi Celtis $\rho \alpha \psi \omega \delta \iota \alpha$ laudes et victoria de Boemannis per septem electores et regem Phoebum, Mercurium, et Bachum et novem Musas personatas publico spectaculo Vienne acta anno MDIIII ${ }^{27}$. Seinen Spott über dieses Schauspiel verstärkt Augustinus noch mit dem Hinweis auf seine aktuelle Lektüre einer Batrachomyomachia ${ }^{28}$, mit der man diesen

Olmütz übergangen wurde und dann in Rom gegen die Entscheidung Einspruch erhob; siehe Czapla, Augustinus Moravus, 63.

22 Ábel, Magyarországi humanisták, 114. (Nr. 8); Rupprich, Briefwechsel, 566, Z. 9-11. (Nr. 313).

23 Vgl. dazu auch das von Moravus herausgegebene Hieronymi Avancii Veronensis ... in Val. Catullum et in Priapeias emendationes ... Venedig: Iohannes Tacuinus, 1495 (GW 3098); 1493 erhielt er von Avantius das Manuskript; siehe dazu Czapla, Augustinus Moravus, 68.

24 Ábel, Magyarországi humanisták, 114-115. (Nr. 9); Rupprich, Briefwechsel, 571-572. (Nr. 317).

25 Ábel, Magyarországi humanisták, 115. (Nr. 9); Rupprich, Briefwechsel, 571, Z. 8-9. (Nr. 317).

26 Ábel, Magyarországi humanisták, 113. (Nr. 6); Rupprich, Briefwechsel, 575-576. (Nr. 320).

27 Augsburg: Iohannes Otmar, 1505, VD 16 C 1897 (online: urn:nbn:de:bvb:12-bsb00007496-5, BSB München; http://data.onb.ac.at/rec/AC08737181 ÖNB Wien). Der Widmungsbrief an Kaiser Maximilian I. vom 1. März 1504 bei Rupprich, Briefwechsel, 552-554. (Nr. 306), der von zwei Ausgaben in Augsburg 1505 spricht (a. O., 576, Anm. 1).

28 Dabei dürfte es sich um das „Epos“ in drei Büchern De bello ranarum des italienischen Dichters Elisius Calentius / Elisio Calenzio (ca. 1430-1503) handeln, dessen Opuscula gesammelt 
Sieg Maximilians gut vergleichen kann. Die nächste Kritik zu einem Werk des Celtis äußert Augustinus am 24. Februar 1505 anlässlich der Zusendung eines panegyricus, quem in laudem deorum tutelarium Austriae cecinisti ${ }^{29}$. Darin preist Celtis unter den Heroen auch Neithart Fuchs und den Pfarrer vom Kahlenberg, wiewohl diese zwei Possenreißer und Windbeutel seien. Nun haben die heidnischen Dichter bereits den Himmel mit Huren und Knabenschändern gefüllt, jetzt hat Celtis auch noch Possenreißer und Schauspieler hinzugefügt. Dies müsse man halt als poetica licentia nach Horaz (ars poet. 10) hinnehmen. Noch einmal drängt Augustinus auf die Zusendung des Germanicus de Boemis triumphus.

Den Abschluss der erhaltenen Korrespondenz zwischen Augustinus Moravus und Konrad Celtis bildet ein Briefwechsel zur Etymologie der Böhmen. Am 4. April 1505 wendet sich Augustinus mit einem recht schroffen Einleitungssatz an Celtis: Sicut in plerisque multis opinioni tuae non consentio, mi Celti, ita neque in eo, ut verum fatear, tecum convenio, ut quos Boiemos Cornelius Tacitus, Bemos autem Ptolomaeus vocat, hos tu - nescio cuius auctoritate - Boemannos appelles ... ${ }^{30}$. Augustinus stößt sich an dem Suffix -mannos, denn wenn man Ritus und Religion der Böhmen betrachtet, müsse man sie eher Bohemandi (quod eorum lingua "Deum manentes" sonat ${ }^{31}$ ) benennen und schließt daran eine Hasstirade an, denn haec ... summa totius religionis ipsorum est, ut et infantes et adulti, senes et decrepiti promiscui sexus ad sacratissimi corporis et sanguinis Christi edulium quottidie ac passim ferantur nulla pecatorum venia per confessionem Christiano more petita; sed veluti asini et sues ad pastum, ita hii ad tanti mysterii cibum solo sensus impetu ducuntur. ${ }^{32}$ Celtis' Rechtfertigungsschreiben für die Bezeichnung ist ebenso überliefert, das Schreiben Augustins vom 4. April 1505 ist dazu terminus post quem. Celtis bedankt sich für das Schreiben und erklärt, weshalb er Augustins Grenznachbarn Boemanni nennt. Dies sei historisch durch probati autores zu erklären: In der Völkerwanderungszeit wurde das nach der Viehzucht benannte Volk der Boii vom lokalen Führer Mannus zum Ansiedeln eingeladen, die Völker haben sich vermischt, und diese Vermischung wurde auch in der Namensverbindung beibehalten.

Diese beiden Briefe waren Celtis so wichtig, dass er sie in der Edition von $\rho \alpha \psi \omega \delta \iota \alpha$ laudes et victoria de Boemannis 1505 just unter einem Holzstich des sehr heroischen Holzstiches zur Schlacht Kaiser Maximilians I. bei Wenzen-

am 12. Dezember 1503 (Rom: Ioannes de Besicken; EDIT 16 CNCE 8415) erschienen. Elisius stammt aus Fratte (= Ausonia in Latium) und war Erzieher des nachfolgenden Königs von Neapel, Federico d'Aragona bzw. I. di Napoli (1452-1504; Kg.: 1496-1501). - Den Hinweis auf dieses Werk verdanke ich Farkas Gábor Kiss.

29 Ábel, Magyarországi humanisták, 113-114. (Nr. 7); Rupprich, Briefwechsel, 581-582. (Nr. 325).

30 Ábel, Magyarországi humanisták, 115-116. (Nr. 10); Rupprich, Briefwechsel, 582-583, Z. 9-15. (Nr. 326).

31 Ábel, Magyarországi humanisták, 116. (Nr. 10); Rupprich, Briefwechsel, 583, Z. 8. (Nr. 326).

32 Ábel, Magyarországi humanisták, 116. (Nr. 10); Rupprich, Briefwechsel, 583, Z. 10-15. (Nr. 326). 
bach am 4. September 1504 platzieren ließ (Abb. 2). Der Holzstich hat die Überschrift: Stratagema regium c(um) Boe(mannis?). Schon dies ist ein feiner Seitenhieb gegen Augustins spöttische Bemerkung zum Werk. Noch viel auffälliger sind hingegen kleinere Änderungen, die Celtis im Brief Augustins für die Drucklegung macht:

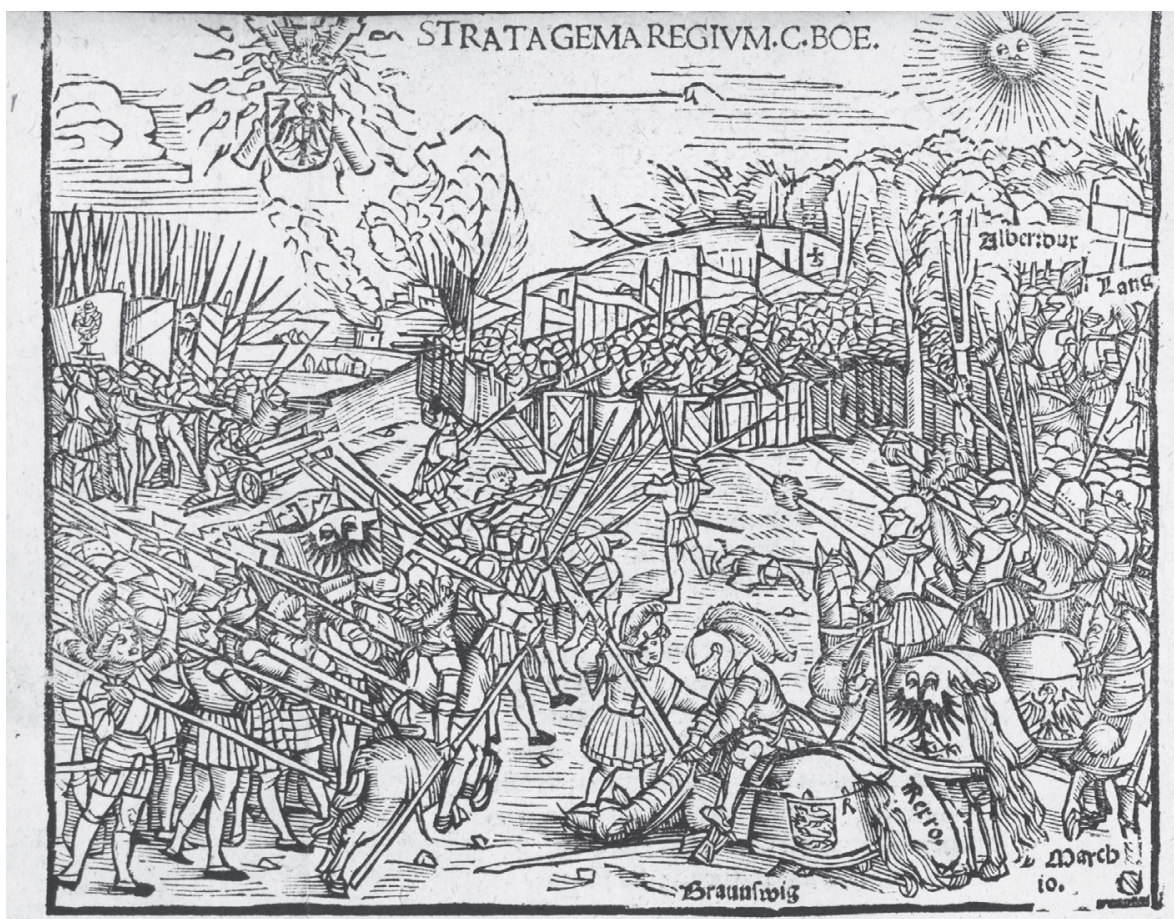

Auguft.Morauus Reg.Boe:Vicecancel.Cbun.Celti-Suo Complatonico.

Non tecữ côuenio mi Celti. Nam quos Boiemos Cor:Bemos aû́t pto.ưocat:bos tu nefcio cuius autoritate Boemános appellas. Quũ fi boim iftorứ téporũ qui Boemiã incolứt ritum et religíoné recteperpédere ue limus:Boemádi potius (quod eorũ lingua deum mandétes fonat) quá boemăni iure effent appellădi. Hec -nffumma totius religionis ipforũ eft ut et infantes et adulti fenes ac decrepiti promifcui fexus:ad facraf tiffimi corpis et fanguinis xp̄i eduliú quotidie ac palfim ferantur:nutha pctörum uenia p confeflioné xp̄ia no more petita:fed ueluti afini et fues ad paftũ:ita bi ad tanti myfterii cibü folo fenfus impetu ducútur.Iu re ergo cos bac rõne Boemádos potius: ạm Boemános uocauerim. Nifi tu certius aligd cur eos fic uoces dfferas:et ualidioribus argumentis me male fenfiffe conuincas. Vale ex Buda.M.D.IIII.

Celtis Auguft. fuo.Miritice me oblectafti epif-tua Auguf.cbariff.lpfe cur collimicios tuos Boemannos tuo cité:accipe. Duas oino potétiffimas gétes(ut apud pbatos autores eft) cómigraffe i germaniă legimus Cel tas et Boios: a pecudư et boũ cura uocitatos. Qui dư ad ripas byftri cốediffent:pafcuofofó faltus et irrigu as ualles in corde ferme germanie rare bitari intellexiffent:a Măno eius regiöis tức duce inuitati:et proti

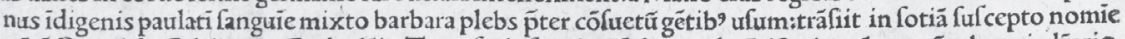
gété.Par rố de Celtiberis:Gotbolăis: Tectolagis fueuis. Vale expbrötifterio nĩo et cótub ernio líario. Vienne.

Abb. 2: Holzstich zur Schlacht Kaiser Maximilians I. bei Wenzenbach am 4. September 1504, darunter der Briefwechsel zwischen Augustinus und Celtis zur Etymologie des Namens Boemanni (Divo Maximiliano Augusto Chunradi Celtis $\rho \alpha \psi \omega \delta \iota \alpha$ laudes et victoria de Boemannis per septem electores et regem Phoebum, Mercurium, et Bachum et novem Musas personatas publico spectaculo Vienne acta anno MDIIII, f. A I [s. Anm. 26]) 
Originalbrief (nach dem Codex epistolaris, ÖNB, Wien, Cod. 3448, f. 161 ${ }^{\text {r }}$ ) Augustinus Moravus Chunrado Celti suo salutem

Sicut in plerisque multis opinioni tuae non consentio, mi Celti, ita neque in eo, ut verum fatear, tecum convenio, ut quos Boiemos Cornelius Tacitus, Bemos autem Ptolomaeus vocat, hos tu-nescio cuius auctoritate-Boemannos appelles ${ }^{33}$.

Druck von 1505, f. A I

Augustinus Moravus regis Boemiae vicecancellarius Chunrado Celti suo complatonico

Non tecum consentio, mi Celti. Nam quos Boiemos Cornelius, Bemos autem Ptolomaeus vocat, hos tu - nescio cuius autoritate - Boemannos appellas.

Dass Celtis im Druck zu Augustinus den offiziellen Titel hinzufügt, um den Wert einer solchen Korrespondenz zu steigern, darf nicht weiter verwundern; jedoch mag gerade die Hinzufügung des offiziellen Titels regis Boemiae vicecancellarius ein kleiner Seitenhieb gegenüber dem folgenden Ausfall Augustins sein. Allerdings macht sich Celtis selbst zu einem complatonicus, und er mildert den recht schroffen Einstieg Augustins, indem er nur mehr die Namensform als Kritikpunkt behält (die Anspielung auf sonstige kritische Dispute der beiden wird getilgt).

\section{Augustinus, Celtis und Ptolemaios}

Diese Passage zur Erklärung der Etymologie von Boemanni ist auch noch unter einem anderen Gesichtspunkt von Interesse, der zur Auseinandersetzung dieser Humanisten mit griechischen Quellen führt. Augustinus erwähnt, dass Ptolemaios diese Nation als Bemi bezeichnet. Hans Rupprich hat in seiner Edition dieses Schreibens dazu angemerkt: „Diese Form sucht man bei Ptolemäus vergeblich“34. Tatsächlich ist es jedoch genau die Form, die Augustinus in einer griechischen Handschrift der Bibliotheca Corviniana, in diesem Fall sogar einer Prachthandschrift, nachlesen konnte (wenn er nicht schon eine der im Umlauf befindlichen lateinischen Übersetzungen benutzt hat). Es handelt sich um den Wiener Cod. hist. gr. 1 der Österreichischen Nationalbibliothek ${ }^{35}$. Diese Handschrift bildete ein weiteres Bindeglied zwischen dem Wiener und dem Budaer Humanistenkreis. Celtis ließ sich von diesem Codex über Ver-

33 Ábel, Magyarországi humanisták, 115-116. (Nr. 10); Rupprich, Briefwechsel, 583, Z. 1-5. (Nr. 326).

34 Rupprich, Briefwechsel, 583, Anm. 3.

35 Zur Verwendung der Handschrift in der Bibliotheca Corviniana siehe Christian Gastgeber, Miscellanea Codicum Graecorum Vindobonensium II. Die griechischen Handschriften der Bibliotheca Corviniana in der Österreichischen Nationalbibliothek. Provenienz und Rezeption im Wiener Griechischhumanismus des frühen 16. Jahrhunderts, Veröffentlichungen zur Byzanzforschung 34 (Wien: Verlag der ÖAW, 2014), 279-290; dort auch ausführliche Literatur zum Themenkomplex. 
mittlung des bereits erwähnten Sekretärs am Hof des Königs Ladislaus II. (Vladislav II.) von Böhmen und Ungarn, Iohannes Schlechta, einem Freund des Augustinus, eine Kopie anfertigen, deren Abschrift (nur des Textes) etwa um 1498 (gegen die vom Kopisten Iohannes Rosenberger erwähnte Datierung 1482) anzusetzen ist ${ }^{36}$; es handelt sich dabei um den heutigen Codex Oxoniensis, Arch. Seld. B 45. Celtis wollte diesen Text ganz offensichtlich für seine eigenen geographischen Arbeiten haben, im Druck gab es bislang nur lateinische Übersetzungen ${ }^{37}$. Die Schreibweise Bemi erklärt sich sehr einfach aus der zeitgenössischen griechischen Aussprache (der Vokale, jedoch nicht des Labials). Im Codex Hist. gr. 1 findet sich der Volksname in der Beschreibung

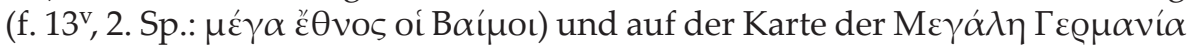

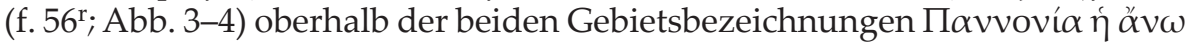

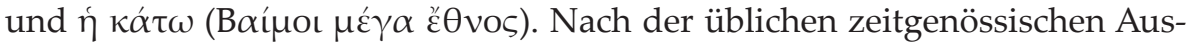
sprache des Diphthongs $\alpha$ ı ergab Baífo die Form Bemi (mit latinisierter Endung) ${ }^{38}$. Es ist nicht auszuschließen, dass Augustinus hier sogar die vorort befindliche griechische Handschrift konsultiert hat.

Celtis hat den Ptolemaios-Text auf jeden Fall für eine Vorlesung verwendet, wie eines seiner Epigramme (V 11) andeutet, mit deutlichem Hinweis auf die griechische Version:

36 Zur Problematik ausführlich Gastgeber, Griechische Handschriften, 280-281; Rosenberger sub-

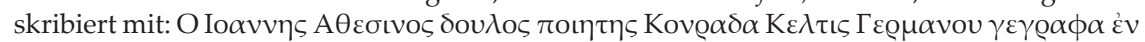
$\varepsilon \tau \varepsilon \iota, \alpha v \pi \beta$ in Buda inferioris Pannonię.

37 GW M36388, Korr. Angelus Vadius und Barnabas Picardus; Vicenza: Hermann Liechtenstein 1475; M36362, Korr. Hieronymus Manfredus; Bologna: Dominicus de Lapis 1462 (1477?) (mit Karten); M36368, Hrsg. Domitius Calderinus; Rom: Arnold Bucking 1478 (mit Karten); M36371, Rom: Nicolaus Han 1482; M36379, Hrsg. Nicolaus Germanus; Ulm: Lienhart Holl 1482 (mit Karten); M36374, Hrsg. Nicolaus Germanus; Ulm: Iohannes Reger für Iustus de Albano 1486 (mit Karten); M36372, Rom: Petrus de Turre 1490 (mit Karten); M36390, Nürnberg: Georg Stuchs ca. 1490 (deutsche Version!).

38 Man vgl. zudem auch die Eintragungen im Druck von Bologna „1462“ (=1477) aus dem Besitz des berühmten Nürnberger Humanisten Hartmann Schedel, einem Amateurgräzisten: f. $16^{\mathrm{r}}$ (gens magna bemorum), f. $70^{\mathrm{r}}$ (Karte, Tafel 5) Bemorum Geus (sic) Maga (sic); von Hartmann in Rottinte zu diesem Gebiet noch die Ergänzung Bohemia regnum (online: urn:nbn: de:12-bsb00032959-2 [BSB-Ink P-857]). Die Form Bemi findet sich in den lateinischen Versionen so noch öfters (Bemi gens magna). - Die antikisierende Aussprache wurde maßgeblich erst mit Erasmus von Rotterdam forciert; siehe Chrys C. Caragounis, „The Error of Erasmus and Un-Greek pronunciations of Greek," Filologia Neotestamentaria 16, 8 (1995): 151-185; Erasmus' Text ist ediert von Johannes Kramer, Desiderii Erasmi Roterodami De recta Latini Graecique sermonis pronuntiatione dialogus. Desiderius Erasmus von Rotterdam, Dialog über die richtige Aussprache der lateinischen und griechischen Sprache, Beiträge zur Klassischen Philologie 98 (Meisenheim am Glan: Verlag Anton Hain, 1978). - Celtis verwendet die Volksbezeichnung Bemi mehrmals in seinen „böhmischen“ Epigrammen (I 64 [De calice Bemorum], I 65 [De rogo Joannis Hus], I 68 [Cavillum Bemorum in Romanum pontificem], I 69 [De calice Bemorum], I 70 [De religione (Bemorum)], I 71 [De piso Bemorum], I 73 [De Bemorum praesule], I 76 [De eodem (sc. I 75 De Vincentino)], I 78 [De Augustino Vincentino]; Edition in Fünf Bücher Epigramme von Konrad Celtes, herausgegeben von Karl Hartfelder [Berlin: Calvary, 1881, Ndr. Hildesheim: Olms, 1963], 16-19). 
Academiae

Cynthius octavam cras postquam ostenderit umbram,

Et croceo rutilum sparserit orbe iubar,

Cosmographia mea tunc incipietur in aede,

Quam magnus scribit Claudius octo libris.

Hanc ego per triplicem Celtis reserabo loquelam,

Romanam, Graiam Teutonicamque simul,

Perque globos solidos coelum terrasque docebo,

Et veteres tabulas edoceamque novas.

Ergo agite, hanc pulchram nemo modo negligat artem,

Qua sine me doctus iudice nullus erit. ${ }^{39}$

Ein Epigramm (III 111) widmet sich generell einem Lob der Geographie des Ptolemaios:

In laudes cosmographiae Ptolemaei

Qui mare, qui terras, vastum qui temperat orbem, In duo divisit cuncta creata deus.

Prima patent oculis sensuque suo capiuntur,

Altera non oculus, mens neque coeca videt.

De primis extrema notas terramque polumque

Et mare, quod terras in tria puncta secat,

Quod monstrat clara Ptolemaeus Claudius arte,

Qui coelum et terram per sua scripta notat.

Digestam terram parallelis ordine miro

Dividit et, vasto quidquid in orbe manet.

Nam mare cum sinubus, montes et flumina pandit

Atque lacus refugis insula cincta fretis.

Climata quin etiam reddit regionibus urbes

Et populos, toto quos modo mundus habet:

Qui caleant Cancro, medius quos torreat axis

Quosve Caper videat, quos vel uterque polus.

Quin etiam adversis qui dant vestigia plantis,

Antipodas alio vivere sole probat.

Alter enim somnum capit atrae tempore noctis,

Ille ubi se lecto sole oriente levat.

Haec tibi certa dabit nitidae successio lucis,

Qua rutilus mundum sol per utrumque volat. ${ }^{40}$

39 Epigramme von Konrad Celtis, 102-103.

40 Epigramme von Konrad Celtis, 71-72. 
Noch ein weiteres Mal wird die Geographie des Ptolemaios in Bezug zu Celtis und Augustinus genannt: In Celtis' Testament vom 24. Jänner 1508 sind auch der Nachlass und die Schenkungen an die Universität geregelt. Zunächst ist festgehalten, dass Celtis der Wiener Universität einen Himmels- sowie einen Weltglobus mit einem griechischen „Ptolemaios“ vermacht ${ }^{41}$. Die gemeinsame Erwähnung der Objekte, die auch zum allgemeinen Gebrauch bereitgestellt sein sollen, lässt auf die „Geographie” besagten Autors schließen.

Am Ende des Testaments werden weiters Fremdentlehnungen u.a. von Büchern genau notiert (und damit deren Rückforderung eingemahnt). Zu den verliehenen Graeca werden Augustinus und der Wormser Bischof Reinhard von Rippur (1503-1523) erwähnt; zu Augustinus ist festgehalten: Dominus Olumutzensis <habet> duas sp<h>aeras et cosmographiam Graecam Ptholemaei. ${ }^{42}$ Rupprich identifizierte den Dominus Olumutzensis mit Augustinus; nach dem Briefcorpus stand Celtis sonst noch in Olmütz mit Gregor Nitsch ${ }^{43}$, Martin Sinapinus ${ }^{44}$ und

41 Rupprich, Briefwechsel, 605, Z. 48-50.

42 Rupprich, Briefwechsel, 608, Z. 134-135.

43 Rupprich, Briefwechsel, 422-424. (Nr. 251; 24. September 1500 aus Olmütz; Celtis und Nitsch stehen zu diesem Zeitpunkt bereits in einem engeren Briefkontakt; Nitsch wurde im Wintersemester 1499 an der Wiener Universität immatrikuliert [Rupprich, a. O., 422-423, Anm. 2] und wohnte mit Celtis zusammen [vgl. dum ipse mensae tuae ascriptus tecum sedula inter fecundos calices opiperaque convivia agerem, a. O., 423, Z. 9-10]. In diesem Brief erkundigt er sich bei Celtis über einen Verdacht gegen den in Wien lehrenden italienischstämmigen Humanisten Hieronymus Balbus, iurista et poeta [ferunt ... Jeronymum Balbum ... quandam haereticam foedamque invisae cuiusdam sectae feturam edidisse. Cuiusmodi autem haec secta sit, non satis scio, a. O., 423, Z. 20-22]. Diese Nachricht hat Nitsch von jemandem aus Prag erfahren. Darin berührt ihn vor allem das wieder thematisierte Problem der Dichterlektüre [quorundam opinio iam dudum de poetis nota firmius ratione istiusmodi novae sectae insidebit, qui dicunt poetas pluris facere gentilium ritus ac colere imitarique plus quam catholicae ecclesiae militantis religionem [a. O., 424, Z. 35-38]), 511 (Nr. 281; 19. Mai 1502 aus Olmütz; Nitsch empfiehlt bei Celtis einen Doktor der Medizin, Arzt von Olmütz, tum dulcissimarum Musarum observatorem, linguae denique Graecae non mediocrem interpretem [a. O., Z. 7-9]), 535 (Nr. 298; 8. September 1503 aus Olmütz; das Schreiben bezeugt das öffentliche Vorlesen der wechselseitigen Korrespondenz in der Sodalitas des jeweiligen Empfängers; im Fall von Nitsch in der Sodalitas Maiorhoviana bzw. Marcomannica; Nitsch empfiehlt Celtis einen Collimitius, utriusque ecclesiae Wratislaviensis canonicus [a. O., Z. 12-13]), 562 (Nr. 310; 12. Juli 1504 aus Olmütz; Nitsch hat den von Celtis empfohlenen magister Georgius [Georgius Boorius Caetianus, s. Anm. 44] empfangen; am Ende wird die Bitte um einen baldigen Besuch des Celtis in Olmütz ausgesprochen), 577 (Nr. 321; 7. Dezember 1504 aus Olmütz; Nitsch übersendet an den Wiener Theologieprofessor und Canonicus von St. Stephan Georg Lantsch ein vasculum mit Zwetschken; Celtis soll Nitsch über den aktuellen Stand des bayerischen Erbfolgekriegs informieren).

44 Rupprich, Briefwechsel, 573-575. (Nr. 319; Herbst 1504 aus Olmütz; nach dem Besuch des Celtis in Olmütz zwischen 12. Juli und 12. September 1504; Celtis erhält zugleich Abdrücke alter Gemmen zu Venus und Saturn; die Sodalitas Maiorhoviana wird Celtis auf dessen Wunsch eine Karte der Marcomannia cum nostra urbe templis effigianda [a. O., 575, Z. 1] zu schicken), 590-592 (Nr. 333; 1505 aus Olmütz; nach Wien werden der Magister Iohannes de Swola [1504 im Sommersemester in der Matrikel der ungarischen Nation der Wiener Universität verzeichnet; a. O., 591, Anm. 3] und der Olmützer Canonicus Wolfgang Lang [ebenso für Sommersemester 1505 in der Matrikel der ungarischen Nation bezeugt] für Lehrveran- 


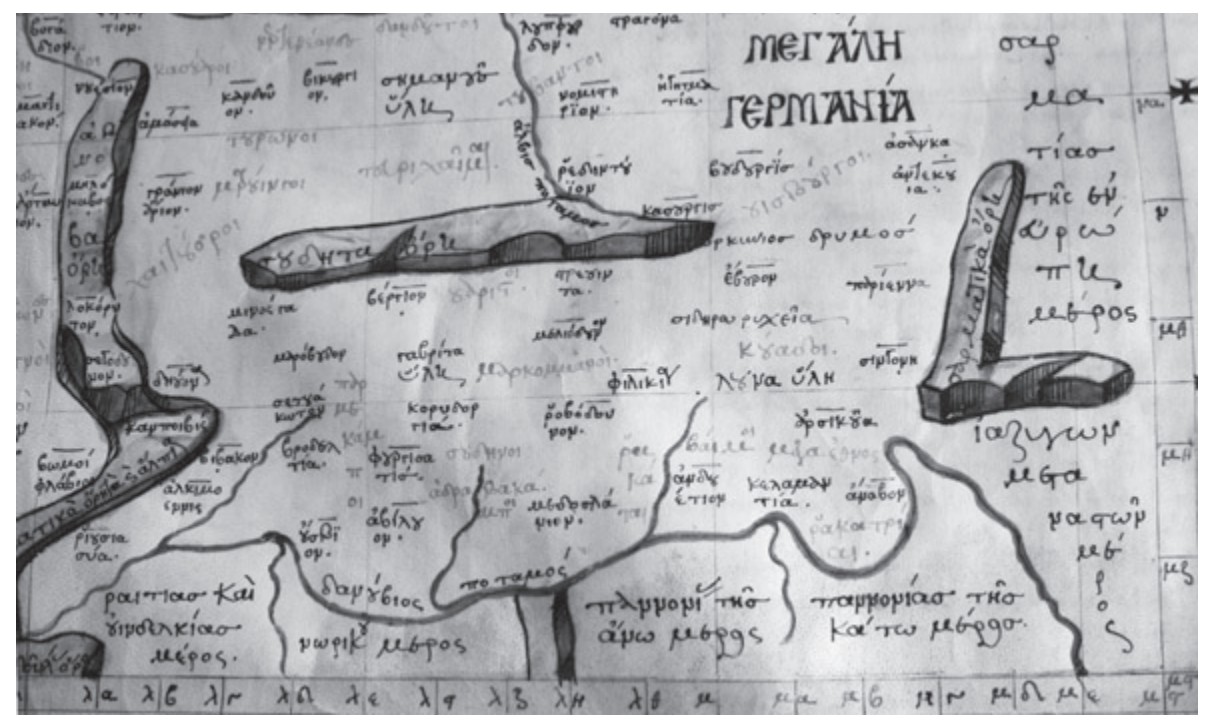

Abb. 3: Baínoı auf der Ptolemaios-Karte der Bibliotheca Corviniana (Wien, ÖNB, Cod. hist. gr. 1 , f. $56^{\text {r }}$ )

Georgius Boorius Caetianus ${ }^{45}$ in Kontakt. Augustinus selbst war zum Zeitpunkt des Testaments längst zum Probst von Olmütz (1506) ernannt. Man wird wohl in dem Ptholemaeus graecus die Oxforder Kopie sehen dürfen, was jedoch nur so zu erklären wäre, dass Augustinus durch seine Entfernung vom Hof in Buda nicht mehr die dortige Prunkhandschrift konsultieren (schon gar nicht an sich nehmen) konnte und (für eigene Arbeiten?) die schon fertiggestellte Kopie des Celtis erbeten haben dürfte. Davon wusste er gewiss durch Iohannes Schlechta bzw. den cosmographus Philippus. 1508 wurde die Handschrift eventuell wieder zurückgefordert; ihre Existenz lässt sich erst wieder im Besitz des Oxforder Gelehrten John Selden (1584-1654) nachweisen, dessen Fundus heute noch als Einheit der Bodleian Library erhalten ist.

staltungen bei Celtis entsendet. Sinapinus schickt zugleich eine jüngst gefundene Silbermünze, Teil eines größeren Neufundes [et sic tui auditoris memor Sinapini, qui ex omni parte Marcomannicas ut formica colligit vetustates; a. O., 592, Z. 25-26]; man erwartet die Rückkehr Augustins, der intelligentia incarnata, nostrum lumen clarissimum [a. O., 592, Z. 27-28], und hofft auch, Celtis bald in Olmütz zu sehen; Georg Booarius Caetianus wird bald nach Wien kommen, taedio ... affectus palaestrae disciplinariae [a. O., 592, Z. 35]).

45 Rupprich, Briefwechsel, 578. (Nr. 322; 1504 aus Olmütz; bezeichnet sich als discipulus tuae dominationis [a. O., Z. 3-4]; der Bischof von Olmütz, Stanislaus Thurzo, hätte sich ein Treffen mit Celtis gewünscht; der Brief endet mit einem Gruß der Sodalitas Maiorhoviana; namentlich genannt sind Martinus Sinapinus und Gregor Nitsch). 


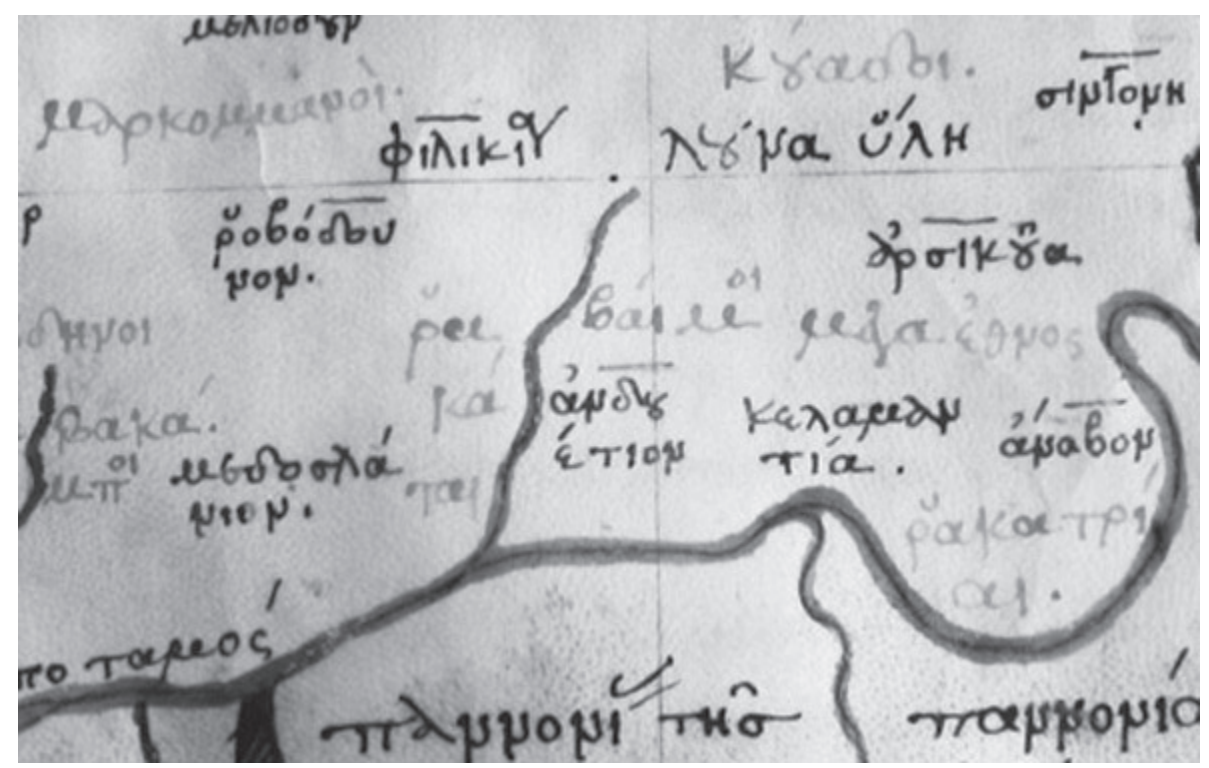

Abb. 4: Detailausschnitt: Boínoı auf der Ptolemaios-Karte der Bibliotheca Corviniana (Wien, ÖNB, Cod. hist. gr. 1, f. 56 ${ }^{\text {r }}$

\section{Moravus im dichterischen Werk des Celtis}

Celtis hat Moravus sowohl durch zwei Epigramme als auch durch eine Ode gewürdigt, die sich bedauerlicherweise zeitlich nicht genau fixieren lassen. Im 4. Odenbuch widmet Celtis ein Gedicht in asklepiadeischer Strophe an Augustinus, „während er bei einem Mädchen alterte“ (Ad Augustinum Olomuncium, dum apud puellam consenesceret $)^{46}$. In spielerischer Form wird Augustin nach dem Beispiel des Paris daran erinnert, sich wieder seinen Freunden der Sodalitas zuzuwenden und nicht durch Missachtung der Bitte der Freunde die Götter herauszufordern. Die im Titel angesprochene amouröse Angelegenheit wird kryptisch angedeutet in den Versen 25-28:

$$
\begin{aligned}
& \text { Heu, pastor temerarie }{ }^{47}, \\
& \text { iam molli penitus pectore saucius } \\
& \text { externaque calens face, } \\
& \text { reddens te placidis, oro, sodalibus. }
\end{aligned}
$$

\footnotetext{
46 Edition in Conrad Celtis, Oden, Epoden, Jahrhundertlied, Libri Odarum quattuor, cum Epodo et Saeculari Carmine (1513), übersetzt und herausgegeben von Eckart Schäfer, NeoLatina 16 (Tübingen: Gunter Narr Verlag, 2008), 304-307.

47 Der pastor nimmt Bezug auf den Vergleich mit Paris und auf seine Jugend unter Schäfern.
} 
Im 5. Buch von Celtis' Epigrammcorpus sind zwei Gedichte (Nr. 28 und 29 ) in Variatio zu einem Buchgeschenk an Moravus erhalten. Das Werk wird bedauerlicherweise nicht namentlich angeführt, nur als vetus libellus bezeichnet, möglicherweise ist Vers 3 in Epigramm 28 als Hinweis auf einen griechischen (in Übersetzung?) oder lateinischen Klassikertext zu verstehen.

\author{
Ad Augustinum Moravum \\ Quondam Celtis eram non vilis amore suppellex, \\ Nunc me Augustinus munera grata tenet, \\ Quem Graecae et Latiae stimulant sub pectore Musae, \\ Cuique sacer Phoebi mente redundat amor.
}

Ad eundem

Hunc tibi iam veterem dono, Augustine, libellum,

Saepe tui Celtis quo meminisse velis,

Ex Moravis primus doctae cui cura Camenae

Et cui Phoebaeo pectus amore calet. ${ }^{48}$

\title{
Moravus und Ioannes Cuspinianus
}

Celtis' Nachfolger auf der Lehrkanzel für Poetik und Rhetorik wurde der aus Schweinfurt gebürtige Humanist Iohannes Cuspinianus (1473-1529), ein führendes Mitglied des Sodalitas litteraria Danubiana, der sich seit etwa Jahresmitte 1492 in Wien befand ${ }^{49}$. Allerdings wurde Cuspinian ab 1510 zunehmend vom Kaiser in diplomatische Missionen nach Ungarn eingebunden, 1512 übernahm seine Lehrtätigkeit als Supplent (bis 1514), dann als Nachfolger (1516-1518) der aus St. Gallen stammende Ioachim Vadianus (von Watt). Beide standen in den Jahren 1511/1512 mit Augustinus in freundschaftlichem Kontakt und sind in Wiener Drucke seiner Werke involviert.

Cuspinian bedankte sich nach der Rückkehr von einer Gesandtschaftsreise am 13. Jänner 1511 in Wien für ein wertvolles Neujahrsgeschenk des Augustinus $^{50}$. Aus seiner Bibliothek wählte er den Libellus de lapidibus preciosis

48 Epigramme von Konrad Celtis, 107.

49 Zur Biographie vgl. Hans Ankwicz-Kleehoven, Der Wiener Humanist Johannes Cuspinian. Gelehrter und Diplomat zur Zeit Kaiser Maximilians I. (Graz, Köln: Böhlau, 1959), 10-11. (zur Ankunft in Wien); ferner Christian Gastgeber, Elisabeth Klecker (Hrsg.), Iohannes Cuspinianus (1473-1529). Ein Wiener Humanist und sein Werk im Kontext, Singularia Vindobonensia 2 (Wien: Präsens Verlag, 2013).

50 Ankwicz von Kleehoven vermutet aufgrund des Attributes artificiosissimus, dass es sich um ein ähnlich kostbares Präsent handelt, wie die mit antiken Münzen verzierte goldene Schale 
des Marbod von Rennes und ließ das Werk bereits am 23. Februar bei Hieronymus Vietor mit einer Widmungsepistel an Augustinus (ff. a1 ${ }^{\mathrm{v}}-\mathrm{a} 3^{\mathrm{r}}$ ) drucken $^{51}$. Darin gibt er auch eine Erklärung seiner Auswahl und führt dem Leser Augustinus als einen exquisiten bibliophilen Humanisten vor: Fastidiosum enim habes (nämlich Du, Augustinus) stomachum, qui quotidiano non oblectatur cibo ac triviales aspernatur dapes. ... Quis enim te uno bibliothecam habet variis, rarioribus melioribusque libris in omni disciplinarum genere refertiorem? Taceo antiquitates insignes, obmitto caesarum consulumque ac regum vetustissima nomismata, quibus apud nostrates nemo est te ditior. ${ }^{52}$

Im selben Jahr erschien in Wien auch Augustins Catalogus episcoporum Olomucensium $^{53}$, dem drei (in den Quantitäten bisweilen misslungene) Distichen an den Leser von Cuspinian vorangestellt ist (f. $\left.\mathrm{A}^{\mathrm{r}}\right)$ :

Ite leves procul hinc, moneo, procul ite prophani,

Neu foedent vestri limina sancta pedes.

Quadraginta senes habitant haec claustra domumque.

Omnibus iis cingit infula sacra caput.

Nulli fas castum scelerato insistere limen.

Nam chorus hic sacer est, sit procul ergo scelus.

für die Societas litteraria Danubiana von 1508. Es bleibt spekulativ, ob die Auswahl just des Buches über die Edelsteine einen aktuellen oder symbolischen Bezug zum Geschenk hat. Cuspinian deutet dies in der Einleitung über die Suche eines passenden Antidoron nicht an.

51 Wien: Hieronymus Vietor 1511, VD 16 M 929; online: urn:nbn:de:bvb:12-bsb00011978-8 (BSB München). Diese Widmungsepistel ist auch abgedruckt in: Johann Cuspinians Briefwechsel, gesammelt, herausgegeben und erläutert von Hans Ankwicz v. Kleehoven, Veröffentlichungen der Kommission zur Erforschung der Geschichte der Reformation und Gegenreformation, Humanistenbriefe, II. Bd. (München: C. H. Beck, 1933), 16-19. (Nr. 8). Cuspinians Handexemplar der Edition von Marbods Libellus ist erhalten in der Österreichischen Nationalbibliothek unter der Druck-Signatur 38.C.78. - Siehe dazu Ankwicz-Kleehoven, Der Wiener Humanist Johannes Cuspinian, 96.

52 Ankwicz v. Kleehoven, Briefwechsel, 16. Cuspinian benützt diese Epistel zugleich auch für eine Abrechnung gegen die medizinischen Fachliteratur und der darin bekundeten Unkenntnis der griechischen Sprache (... multorum morborum remedia, quibus scatent medicorum codices, licet multa in parte sint in iis et nomina depravata et virtutes confusae, ut inde divinare quis facilius posset quam rem ipsam explicare. Fecit enim ignorantia litterarum graecarum huiusmodi monstra et interpretum negligentia quottidie parit errores graviores et subinde periculosiores, quos oculati tantum vident et qui lingua utraque sunt instituti; de quibus peculiare opusculum conscripsi, quod ad te mittam propediem [a. O., 18]. - Mit dieser Formulierung wird sogleich suggeriert: Wir beide, Cuspinian und Augustinus, gehören natürlich zu den Kennern der griechischen Sprache). Ebenso eröffnet er abschließend noch eine Front gegen die nostra tempestate indoctissimi et infantissimi homuntiones doctrinae parum, prudentiae nihil habentes, die nur sieben Todsünden bzw. sieben Gaben des Heiligen Geistes einhalten, ut quidam nuper septenarium numerum laudavit. Diese deliramenta verbreiten sie nicht nur um ungebildeten Volk, sondern publizieren sie sogar für die Gelehrten (a. O., 19).

53 Wien: Hieronymus Vietor, Iohannes Singriener, 8. März 1511 (VIII. Eid. Mar.); VD 16 K 8. Siehe dazu auch Ankwicz-Kleehoven, Der Wiener Humanist Johannes Cuspinian, 98-99. 
Bei dem am 14. Mai 1512 in Wien gedruckten Antilogion Guarini et Poggii de praestantia Scipionis Africani et C. Iulii Caesaris, nuper ${ }^{54}$ doctissimi Augustini Moravi cura in lucem editum ${ }^{55}$ nimmt Cuspinian - aufgrund seiner diplomatischen Verpflichtungen - nicht mehr teil; die Paratexte stammen von Vadian (ff. A 2 ${ }^{\mathrm{v}},\left[\mathrm{I} 5^{\mathrm{v}}-\mathrm{I} 6^{\mathrm{r}}\right]$ ) und Stephanus Taurinus (Stieröxel) ${ }^{56}\left(\mathrm{ff} . \mathrm{A} 1^{\mathrm{v}}-\mathrm{A} 2^{\mathrm{r}}\right.$ ). Eine vorangestellte Widmungsepistel Augustins an Vadian lässt Cuspinian zwar herzlich grüßen, direkt angeschrieben wird er jedoch wegen seiner spärlichen Anwesenheit in Wien nicht ${ }^{57}$.

\section{Moravus und Ioachim von Watt (Vadianus)}

Der bereits erwähnte Nachfolger Cuspinians, Vadian, gehörte ebenfalls zum gelehrten Freundeskreis Augustins und drückt dies durch Lobgedichte in zwei Wiener Editionen von Werken Augustins aus. Wie Cuspinian beteiligte er sich im März 1511 mit einem Gedicht auf Augustins Catalogus episcoporum Olomucensium $^{58}$ (f. $\mathrm{A}^{\mathrm{r}}$ ):

Doctissimo Augustino Moravo supremo regis Ungariae secretario Ioachimus Vadianus

Pontificum quod sancta refers memorandaque saeclis

Nomina et ex sacris nobile ducis opus,

Augustine, tibi tantum proba pectora debent

Elysio quantum haec turba sacrata senum.

Te siquidem ductore redit virtusque fidesque

Et redit excultae relligionis amor,

Nam dum clara legit praesul monumenta superstes,

Nimirum virtus gratior inde sibi est.

Haec facis, ut vigeat cultis mandata libellis,

Caetera cuncta dies longior interimit.

Während Augustinus den Katalog noch dem Olmützer Bischof Stanislaus gewidmet hat, steht Vadian im folgenden, gleichfalls in Wien gedruckten Werk, dem Antilogion Guarini et Poggii de praestantia Scipionis Africani et C. Iulii

54 Es handelt sich um Augustins Erstveröffentlichung wie im Drucker-Impressum [I $\left.6^{\mathrm{r}}\right]$ vermerkt: Excusus hic non antea vulgatus liber.

55 Wien: Hieronymus Vietor \& Johannes Singriener, 14. Mai 1512 (Pridiae Idus Maias anno M.D.XII); VD 16 G 3856.

56 Zur Person siehe Franz Josef Worstbrock, „Taurinus, Stephanus (Stierochs, Stieröxel),“ in Deutscher Humanismus 1480-1520. Verfasserlexikon, Bd. 2, L-Z, herausgegeben von Franz Josef Worstbrock (Berlin, New York: De Gruyter, 2013), 1052-1058.

57 Vgl. den Text der Epistel unten bei Moravus.

58 Siehe Anm. 53. 
Caesaris $^{59}$ vom 14. Mai 1512, als Widmungsträger mit entsprechender Epistel im Mittelpunkt (darauf folgt noch eine eigene Epistel an den Breslauer Fürstbischof Iohannes Thurzo [ff. A $3^{\text {rv }}$ ]); demnach ging die Initiative zur Kontaktaufnahme von Vadian aus, der sich durch lobende Erwähnung Augustins dessen Wohlwollen und Freundschaft erwerben wollte:

Augustinus Moravus iuris pont(ificii) doctor, Olomuncensis et Brunnensis praepositus metropolitanaeque Pragensis ac utriusque Vratislaviensis ecclesiarum canonicus clarissimo viro Ioachimo Vadiano, Musarum antistiti celebrato salutem dat.

Plurima cotidie exhibes observantiae in me tuae, Vadiane eruditissime, testimonia, cum te tamen nullo unquam, quod sciam, beneficio demeruerim. Exornasti me nanque inprimis in Olomucensium pontificum catalogo elegantissimo decastico in eoque insuper Hutteni ad Caesarem celsitudinem elegidio honestiss $<i>$ mis me titulis illustrasti, ut me dubium plane reddideris, quonam tibi vicissim xenio ac munere gratificari debeam. Non quidem solido, quod aiunt, $\mathrm{e}^{60}$ Clibano bove, sed vel portiuncula aliqua Sylofonteae illius chlamidis, qua ille tenui re maximam comparavit. Nunc vero, quum Hieronymus Vietor et Ioannes Singrenius calcographi impressuri sint, Guarini et Poggii concertationem de Scipionis Africani et Iulii Caesaris praestantia, quam reverendissimo Vratislaviensi antistiti nuncupavi, obsecro operi secundarias saltem horas impendas, in emendanda vero liminari mea epistola aristarcheam etiam virgulam exerceas adhibitis contubernii tui celebratissimis vatibus Aperpacchoque potissimum, qui me nuper hendecasyllabo carmine tecum una concelebravit ${ }^{61}$. Scripsissem gymnasii etiam vestri polyhistori Ioanni Cuspiniano, sed cum ob Caesarea maiestatis negotia raro adsit, vos mihi interea hanc operam iterum atque iterum exorati locate. Ex Olomuncio Idibus Februariis M.D.XII.

Vadian steuerte zu diesem Werk zwei Paratexte bei: eine subitaria crisis in Hendekasyllaben am Anfang (f. A $2^{\mathrm{v}}$ ) und eine anacephaleosis ${ }^{62}$ in iambischen Senaren [ff. I $5^{\mathrm{v}}-6^{\mathrm{r}}$ ] am Ende.

In der Epistel bedankt sich Augustinus auch für seine lobende Erwähnung in der Widmungsepistel Vadians zur Ad Divum Maximilianum Caesarem

59 Siehe Anm. 55.

60 Der Text hat vel; die Korrektur folgt den Castiganda auf [f. I $6^{\mathrm{r}}$ ].

61 Dieses Gedicht von Petreius Aperbach (Eberbach; zur Person siehe Heinrich Grimm, „Aperbacchus, Petreius", in Neue Deutsche Biographie 1 (Berlin: Duncker \& Humblot, 1953 [Ndr. 1971]): 324. (Onlinefassung: URL: http://www.deutsche-biographie.de/pnd131533215.html), eines Mitbewohners Vadians und von Huttens in Wien, ist am Ende des Catalogus episcoporum Olomucensium [f. B $6^{\mathrm{r}}$ ] gedruckt.

62 Vadian nützt die sehr divergierende Darstellung von Caesar und Scipio durch Poggio und Guarino für eine generelle Überlegung zum Nachleben der Taten durch Tugend und die Macht der Neider. 
Augustum F. P. bello in Venetos euntem, Ulrici Hutteni equitis exhortatio vom Jänner $1512^{63}$. Dieses Widmungsschreiben richtete Vadian an den Wiener Humanisten und Kollegen Georg Tannstetter Collimitius ${ }^{64}$, studii Viennensis vicecancellarius (f. $\mathrm{A}^{\mathrm{v}}$ ). Anlass des Druckes war ein Besuch Huttens einige Monate zuvor, bei dem Letzterer über seine Odysseus-ähnliche Peregrinatio berichtet und ein fertig geschriebenes Gedicht der Gelehrtenrunde zur Begutachtung vorlegt; es gefällt allen, man macht eine Kopie, und Vadian lässt es schließlich bei Hieronymus Vietor und Iohannes Singriener in Druck geben. In der Widmungsepistel kommt auch die freundliche Aufnahme in Olmütz zur Sprache (ff. A $1^{\mathrm{v}}-\mathrm{A} 2^{\mathrm{r}}$ ), dabei wird das Wirken Augustins mit homerischem Vergleich gewürdigt.

... Rursus vero Mercurio suo ita instigante per saltuosa Bohemiae pannosus et naufragio squallens in Moraviam illam fertilitate Corcyre fere parem ut casu venerit ibique ad Stanislaum episcopum Olomucensem, studiosorum et Musas colentium Alcinoum liberalissime deductus fuerit, non quidem a Nausicaa, quae illic nulla erat, sed ab Echeneo Heroe, hoc est Augustino Moravo, qui summa eruditione et prudentia vir, Hutteno appulso, cum ingenium novit, ex officio est patrocinatus, quemadmodum Echeneus apud Homerum in Odissea 7 Ulyssem peregrinum in Alcinoi auro gemmisque lucescentem <in?> aulam induxit minime passus ad focum eum in cinere ultimum sedere; cui episcopo quam grata fuerit Hutteni presentia, certum faciebant et alacris sonipes, quem ei dono dedit, et largum admodum viaticum, quo ad nos usque pervenit, tum annulus ex auro et insigni gemma, $\mathrm{ab}$ Augustino proposito ${ }^{65}$ donatus, quem summa utriusque laude et commendatione crebro digito girabat.

Am 5. Dezember 1513 erschienen in Straßburg zwei Schriften des griechischstämmigen Kardinals Bessarion (Oratio de sacramento eucharistiae et quibus verbis Christi corpus perficiatur und Epistola ad Graecos) ${ }^{66}$. Die Edition besorgte Sebastian Murrho iun. aus Kolmar, der sich in einer Widmung an Vadian für die Besorgung der handschriftlichen Druckvorlage durch die Ver-

63 Wien: Hieronymus Vietor, Iohannes Singriener, Jänner 1512; VD 16 H 6242. Abgedruckt auch in Ulrichi Hutteni equitis Germani opera, quae reperiri potuerunt omnia, ed. Eduardus Böcking, Vol. 1, Epistolae Ulrichi Hutteni equitis item ad eundem deque eodem ab aliis ad alios scriptae (Leipzig: Teubner, 1859 [Ndr. 1963]), 22-24. (Nr. 10).

64 Zur Person siehe Franz Graf-Stuhlhofer, Humanismus zwischen Hof und Universität. Georg Tannstetter (Collimitius) und sein wissenschaftliches Umfeld im Wien des frühen 16. Jahrhunderts (Wien: WUV-Universitätsverlag, 1996).

65 praeposito?, vgl. etwa auch die Praefatio des Sebastian Murrho zu der im Folgenden angeführten Edition zweier Schriften Bessarions.

66 Straßburg: Matthias Schürer, 5. Dezember 1513 (Nonis Decembribus An. M.D.XIII [f. A II ]; VD 16 B 2256, B 2253). 
mittlung Augustins aus der Bibliotheca Corviniana bedankte ${ }^{67}$ (ff. A II ${ }^{\mathrm{rv}}$ ). Er nutzte das Vorwort zugleich für eine Abrechnung mit den Humanismus-feindlichen Klerikern und stellt Augustinus als lobenswerte Ausnahme eines Humanistenfreundes vor.

Oratio autem haec de eucharistia, quam tu nobis, Ioachime Vadiane, imprimendam misisti, Bessarionem non minus subtilem fuisse theologum quam philosophum acutum, ni fallor, ostendet. ... Hae tantae res in oratione una et una item epistola continentur. Quapropter publice quidem studiosi omnes, praecipue sacris initiati, quorum res agitur, privatim Bessarionis ipsius manes gratias tibi, mi Vadiane, maximas, sed multo maiores Augustino Moravo, praeposito Olomucensi habebunt; huic quod studuerit e pulverulentis inferioris Pannoniae bibliothecis eruere et in lucem proferre, tibi, quod inprimi curaveris. Est is praepositus (ut scribis) vir tum magna sapientia, tum politioris literaturae amantissimus, a cuius certe instituto multum abhorrent nostrates (pace quorundam dixerim) et praepositi et canonici. Qui utinam se non tantum inani quadam doctrinae umbra venditarent, sed literas etiam humaniores amplecterentur aut, si amplecti nollent, studiosos earundem foverent aut saltem non insectarentur. Sed surdis fabulam. Ego Augustinum illum virum magnum et praestantem iudico. Cui dicatum esset hoc quicquid est libelli, si fuisset nobis vel de facie notus. Tibi (sc. Vadian) dicavimus, cuius opera et diligentia ad nos pervenit.

Ein Schreiben im Briefcorpus Vadians macht in aller Deutlichkeit klar, wie fragmentarisch unsere Überlieferung der Werke Augustins ist. Am 11. Dezember 1516 meldet sich der Olmützer Domherr Stephanus Taurinus (Stieröxel) aus Esztergom mit einer Bitte ${ }^{68}$ : Er erinnert sich, dass Vadian mit Augustinus einen sehr freundschaftlichen Umgang hatte. Daher meint Taurinus, dass zwischen den beiden ein sehr reger Briefwechsel existiert haben müsste (ut erat hominum studiosorum amantissimus). Davon erbittet er Abschriften, denn der Fürstbischof von Breslau, Iohannes Thurzo, möchte eine Edition der Briefe des Augustinus vorbereiten. Diese Kopien könne er gleich seinem Briefboten Aegidius mitgeben.

67 Vgl. Ankwicz-Kleehoven, Der Wiener Humanist Johannes Cuspinian, 111-112. Der Codex befindet sich nunmehr in Budapest: Országos Széchényi Könyvtár, Cod. Lat. 438.

68 Emil Arbenz, „Die Vadianische Briefsammlung der Stadtbibliothek St. Gallen I, Mitteilungen zur Vaterländischen Geschichte XXIV, 3. Folge, IV 1 (1890): 174 (98) (Nr. 83). Taurinus ließ 1519 in Wien bei Iohannes Singriener seine epische Stauromachia id est Cruciatorum Servile Bellum drucken (VD 16 T 274); zum Werk siehe László Szörényi, „L'influenza della Farsaglia di Lucano sull'epopea tardo-umanista latina in Ungheria. Stephanus Taurinus: Stauromachia," Neohelicon 27, 2 (2000): 97-111. 



\section{"Natio germanica" der Bologneser Universität und ausländische Studenten von Filippo Beroaldo dem Älteren}

Besonders in der Renaissance zog Italien verschiedene deutsche Studenten an, die als Mittler humanistischer Ideen wieder in ihr Heimatland zurückkehrten. ${ }^{1}$ Sie brachten, humanistisch gebildet, neue Tendenzen, neue Möglichkeiten gewagter Interpretationen, neue philosophische Ansätze und neues Weltanschauungspotenzial mit. Ihr in Italien geübter und ausgebildeter Geist strebte nach Veränderungen in ihrem Heimatland. Diese Veränderungen geschahen nicht nur auf der politischen und wirtschaftlichen, sondern auch auf der empirischen Ebene, auf dem Gebiet der Dichtung und der Philosophie. So übte beispielsweise Filippo Beroaldo mit seinen innovativen Übersetzungen der italienischen Autoren Boccaccio und Petrarca ins Lateinische einen großen Einfluss auf die zeitgenössische niederländische und deutsche Lyrik aus ${ }^{2}$ und wurde selbst in verschiedene Sprachen übersetzt. ${ }^{3}$

Die Bologneser Universität, an der Filippo Beroaldo lehrte, war schon im 14. Jahrhundert als eine berühmte Rechtsschule in vielen Ländern Europas bekannt, im 15. Jahrhundert wurde sie auch eine angesehene Rhetorikschule mit einem großen Anteil ausländischer Studenten, sogenannten ultramontani (oder natio germanica), und entwickelte sich zu einer der bedeutendsten humanistischen Schulen der Renaissance, die einen nicht zu unterschätzenden Einfluss auf die Entwicklung des politischen Wesens, der Wissenschaft und der Reformationsbewegungen in ganz Europa und insbesondere in seinem östlichen Teil hatte.

Wie Sorbelli schreibt, gehörten Anfang des 15. Jahrhunderts alle ausländischen Studenten aus Osteuropa, zu dem auch Deutschland zählte, zur natio germanica, da die meisten wohl aus Deutschland kamen und da die meisten Länder „hinter dem Berg”, oder eher „hinter den Bergen”, also den Al-

1 Carlo Calcaterra, Alma mater studiorum (Bologna: Zanichelli, 1948), 154-155.

2 Solche Dichter wie Balthasar Kittel, Heinrich Boger, Henning Fauerhane, Sebastian Franck, Jakob Frölinkint, die Brüder Jakob und Andreas Canter, Hermann v. d. Busche, Jakob Locher sowie früher Jakob Wimpfeling. Cf. Georg Ellinger, Italien und der deutsche Humanismus in der neulateinischen Lyrik (Berlin: W. de Gruyter \& Co., 1929), 107, 372, 380, 400, 423, 428. Der Autor tut die Übersetzungen Beroaldos als geschmacklose schulmeisterliche Versuche ab, obwohl er ihren Einfluss auf die deutschen und niederländischen Autoren der Zeit nicht negiert.

3 Anna Rose, Filippo Beroaldo der Ältere und sein Beitrag zur Properzüberlieferung (München-Leipzig: Saur, 2001), 145-150. 
pen, lagen. ${ }^{4}$ Finger spricht zwar von "Angehörigen der ersten Familien Deutschlands", 5 aber auch französische, böhmische, polnische und ungarische Studenten zählten dazu. Die böhmischen Studierenden gehörten nach dem territorialen Prinzip zur natio germanica im 13. und im 15. Jahrhundert, als ihre Anzahl an der Universität nicht groß genug war, um eine selbständige Studenteneinheit zu bilden. Polnische Studenten bildeten in dieser Zeit ebenfalls einen Teil der natio germanica, die meisten von ihnen kamen aus Schlesien, das damals nicht wie heute zu Polen, sondern zu Deutschland gehörte. Im 15. Jahrhundert stellten ultramontani einen bedeutenden Anteil an der Gesamtbevölkerung Bolognas und prägten wesentlich das Bild dieser Universitätsstadt.

An allen italienischen Universitäten, deren Studentenschaft ab 1197 in zwei Gruppen, in italienische (universitas citramontanorum) und in ausländische (universitas ultramontanorum) ${ }^{6}$ Studenten, geteilt wurde, spielten die Nationen der jeweiligen Gruppe, im Gegensatz zu den deutschen Universitäten des Mittelalters, eine sehr wichtige Rolle. Die nationes stellten eine organisierte Form der studentischen Selbstverwaltung dar und funktionierten nach dem Prinzip einer religiösen Bruderschaft ${ }^{7}$ (confraternitas), die ihren Mitgliedern Schutz und einen geregelten Ablauf der Studienzeit sowie seelischen Trost in schweren Zeiten garantierte. ${ }^{8}$ In den Statuta nationis germanicae wurde die Hauptaufgabe der Nation so geschildert: ... ut hec nostra congregatio, omni dempta necessitate, solum honestum, solumque decorum inclite Germanice Nationis fovere estimetur, utilitatis tamen et publice et private, nequaquam expers credenda, presertim ex qua fraterna caritas, societatis amicitieque communicatio, infirmorum consolatio et egenorum subsidium, funerum deductio et rancoris simultatumque extirpacio, tum doctorandorum nostrorum in locum et ex loco examinis comitiva atque constipacio bona spiritualia resultarent. ${ }^{9}$

Die deutsche Nation war die wichtigste sowie die am besten vertretene in Bologna und in Padua, da jeder fünfte der ultramontani ein Student aus dem deutschsprachigen Raum war; es waren durchschnittlich 100 Studenten jährlich. ${ }^{10}$ Die deutsche Nation genoss auch die größten Privilegien. ${ }^{11}$

4 Albano Sorbelli, „La 'Nazione' nelle antiche università italiane e straniere," Studi e memorie per la storia dell'Università di Bologna, 16 (1943), 93-232.

5 Richard Finger, Bologna und die Deutschen im Mittelalter (Bremen: Geist, 1941), 30-32.

6 Gina Fasoli, Per la storia dell'Università di Bologna (Bologna: Pàtron, 1970), 133-134; Finger, Bologna und die Deutschen, 32.

7 Pearl Kibre, The Nations in the Mediaeval Universities (Cambridge (Mass.): Mediaeval Acad. of America, 1948), 43.

8 Walter Steffen, Die studentische Autonomie im mittelalterlichen Bologna (Bern-Las Vegas-Frankfurt am Main: Peter Lang, 1981), 87.

9 Paolo Colliva, Statuta Nationis Germanicae Universitatis Bononiae (1292-1750) (Bologna: Associazione italo-tedesca, 1975), 129.

10 Finger, Bologna und die Deutschen, 31. Colliva, Statuta Nationis Germanicae, 69.

11 Carlo Malagola, Monografie storiche sullo studio Bolognese (Bologna: Zanichelli, 1888), 225. 
Ihre erste Erwähnung fällt auf das Jahr 1265, dementsprechend ist es anzunehmen, dass sie nicht viel früher gegründet wurde. ${ }^{12}$

Allerdings bestand die natio germanica, die 1265 eine der 13 nationes ultramontanorum ausmachte, ${ }^{13}$ schon zu Beginn des Mittelalters nicht nur aus deutschstämmigen Studenten. Die Norweger waren ab 1291 Mitglieder des Verbandes, die Studenten aus den „Frieslanden” und „Dakien” 14 ab 1292, die Schlesier ab 1296. Im Jahre 1322 kamen dazu die Studenten aus Böhmen, Litauen, Mähren und Dänemark, ${ }^{15} 1323$ die Studierenden aus Schwaben, Bayern, Sachsen und Franken, 1327 aus Lettland, 1448 aus Finnland, die Studenten aus Flandern gehörten aber lediglich bis 1475 zur natio germanica. ${ }^{16}$

Das erste schriftliche Zeugnis der geregelten Existenz der deutschen Nation in Bologna sind die Statuta nationis germanicae aus dem Jahre $1497 .{ }^{17}$ Dabei schloss sie bis in das 15. Jahrhundert nur die Vertreter der juristischen Fakultät ein, erst in den späteren Jahrzehnten der Existenz der natio germanica wurden auch die Studenten der sogenannten "Artistenfakultät” (artes) ${ }^{18}$ aufgenommen. Die Vorliebe für juristische Studien zeugte nicht nur von der Bestrebung, eine juristische Laufbahn einzuschlagen, sondern - und wahrscheinlich auch vor allem - vom Wunsch, gerade durch dieses praktische Studium an der Bologneser Universität in den Genuss humanistischer Studien $\mathrm{zu}$ kommen, ${ }^{19}$ die später zu jeder Karriere im Heimatland verhelfen konnten, also nicht nur dem Staatsdienst oder zur politischen Laufbahn, sondern auch zu einer philosophisch-literarischen.

12 Malagola, Monografie storiche, 227.

13 Antonio I. Pini, "Discere turba volens: Studenti e vita studentesca tra autorità e disciplinamento," in Studi e memorie per la storia dell'Università di Bologna, nuova série, VII, (Studenti e università degli studenti dal XII al XIX secolo), 1988, 63.

14 Diese Landesnamen wurden in deutscher Übersetzung aus den Statuta nationis germanicae übernommen. Unter Dakien verstand man im Altertum das Land zwischen Theiß, Donau und Dnjestr.

15 Über die Begründung der Zugehörigkeit dieser Nationen zur natio germanica in den Statuta cf. Miroslav Boháček, „Note marginali agli statuti della nazione tedesca a Bologna recentemente scoperti," in Studi in onore di Odoardo Volterra, VI. (Milano: Giuffrè, 1971), 14. Missverständlich äußert sich Steffen, Die studentische Autonomie, 30: „Im Unterschied zu Paris ... herrschte in Bologna ein ausgesprochener Partikularismus: Hier sind keine Fusionen von Landsmannschaften bekannt und selbst die kleinste, die böhmische Nation war stolz auf ihre Souveränität." Im vorliegenden Beitrag werden nur die Studenten aus den geographischen Regionen des heutigen Deutschlands betrachtet.

16 Paolo Silvani, „Bologna, storica sede delle relazioni giuridiche italo-germaniche,” in Rendiconto delle sessioni della R. Accademia delle scienze dell'Istituto di Bologna, classe di scienze morali, serie IV, v. IV, 44, 1940, 123; Malagola, Monografie storiche, 233-234. Zu den Studenten aus Sachsen zählten diejenigen aus Niedersachsen, cf. Finger, Bologna und die Deutschen, 33.

17 Eine genaue Aufschlüsselung der Kontinuität der Zuwanderung, der Herkunftsländer und der Anzahl der ausländischen Studierenden im Laufe des Mittelalters lässt sich kaum machen, obwohl einzelne Perioden gut dokumentiert sind. Cf. Pini, „Discere turba volens”, 62-69.

18 Finger, Bologna und die Deutschen, 32. Cf. Pini, „Discere turba volens”, 56.

19 Finger, Bologna und die Deutschen, 30. Colliva, Statuta Nationis Germanicae, 71. 
Eine natio bildete eine nationale Einheit an einer Universität und war außerdem auch selbst eine kleine universitas. Daher gehen die Begrifflichkeiten in vielen Studien auseinander. Manche Forscher sprechen lediglich von natio, die anderen von der Universität. Dies sorgt für ein ständiges qui pro quo, denn zu klären bleibt die Frage, in welchem Zusammenhang der Begriff Universität benutzt wird. Aus unserer Sicht ist es angemessen, die natio als eine Untereinheit der Universität zu verstehen und immer darauf zu achten, dass das Wort „Universität” nur in Bezug auf die Gesamteinrichtung der Bologneser Universität gebraucht wird.

Die natio germanica funktionierte wie ein organisierter Verein, hatte ihre Exekutivorgane und versammelte sich ab 1289 in der Bologneser Kirche von San Frediano (hinter dem Tor San Mamolo). Diesen Ort behielt sie ständig als ihren Hauptsitz, dort wurden auch sämtliche Feste der natio gefeiert. Der natio standen zwei procuratores ${ }^{20}$ vor, die als Mitglieder des Verwaltungsorgans der Nation dienten, sie überall vertraten und sogar wie die Rektoren der beiden universitates eine Sondererlaubnis für das Tragen von Waffen im Dienst hatten, ${ }^{21}$ was ihre Gleichstellung mit den Vertretern der kommunalen Verwaltung von Bologna symbolisierte. ${ }^{22}$

Da kein Mitglied einer Nation einen Fremden zur Beilegung von Streitigkeiten zwischen Vertretern zweier oder mehrerer Nationen heranziehen durfte, übernahmen die procuratores auch die jurisdikativen Aufgaben von Schlichtern und Richtern. ${ }^{23}$ Zur allerwichtigsten Pflicht der procuratores gehörte jedoch die Entgegennahme der Studiengebühren, die 5 bis 60 solidi pro Monat betrugen und einkommensabhängig waren, sowie die Eintreibung von Schulden. ${ }^{24}$ Außer aus den Studiengebühren bezog die Nation ihre Einnahmen aus den Strafgebühren, die ihre Verwaltung sammelte, und vom Weinanbau. ${ }^{25}$

Jede natio hatte das Recht, die Rektoren zu wählen. Sie repräsentierten die Universität, übten die Rechtsgewalt über Studenten aus, verteilten Unterrichtsstunden an Dozenten, ${ }^{26}$ verkehrten mit der Kommune, regulierten den Kauf, Verkauf und die Leihe der codices und übernahmen andere administrative und finanzielle Funktionen, wie die Verwaltung von Studiengebühren

20 Nur die deutsche Nation besaß das Recht, zwei procuratores statt eines zu wählen. Sie waren auch nicht im Gegensatz zu den consiliarii anderer Nationen dem Rektor unterstellt. Kibre, The Nations, 30, 43.

21 Silvani, „Bologna, storica”, 130; Kibre, The Nations, 38-39.

22 Colliva, Statuta Nationis Germanicae, 76.

23 Kibre, The Nations, 35.

24 Ibid., 30, 33-34. In den Statuta hieß es: „Sin ... scolares nomina sua discendentes solvere minime curaverint, et illorum creditores ad prefatos procuratores querelam facerent, seu reclamaverint ex tunc, si debitum liquet, ad eum, si eius copia haberi potest, alioquin ad eius parentes, vel propinquos monitorie littere nomine tocius et sub sigillo Nationis scribentur." S. in: Colliva, Statuta Nationis Germanicae, 136.

25 Kibre, The Nations, 34.

26 Dies war ihr Hauptprivileg seit der Authentica Habita. Carlo Malagola, I rettori nell'antico Studio e nella moderna università di Bologna (Bologna: Coi tipi Fava e Garagnani, 1887), 8. 
oder Staatsabgaben ${ }^{27}$ und die Aufsicht über die ordentliche Abhaltung der Vorlesungen. ${ }^{28}$ In der Ausübung ihrer Gewalt wurden sie jedoch durch die Vorschriften der Statuta und durch die Stimmkraft der Gesamtversammlung eingeschränkt, ${ }^{29}$ und stellten somit ein demokratisches Institut innerhalb der Universität dar. Die meisten Rektoren der ultramontani waren Deutsche (insgesamt 36), weil die deutsche Nation das Recht hatte, einen Rektor aus ihren Reihen einmal in fünf Jahren zu wählen. ${ }^{30}$

Die Statuta der Nation mussten zwei Mal im Jahr, am Epiphanienfest und zu Pfingsten, vor der Nationsversammlung laut verlesen werden. Als Sonderfeiertage waren das Fest der Heiligen Katharina, der Patronin der Nation, des Heiligen Nikolaus und des Heiligen Martins angesetzt. Das Trinken (potationes) war darüber hinaus nur an bestimmten Tagen erlaubt. ${ }^{31}$ Die privilegierte Stellung der deutschen Nation wird durch das Sonderrecht der Studenten bewiesen, einen Eid nur gegenüber den procuratores eigener Nation zu leisten, während die Studenten anderer Nationen noch dem Rektor der Universität und der Staatsverwaltung unterstellt wurden. ${ }^{32}$

Die anderen Ämter der natio waren die für den Kirchendienst zuständigen Kapläne, Syndizi, Wahlmänner und die sogenannten bidelli (Pedelle) ihre Aufgabe bestand in der Studentenbetreuung während des Studentenlebens in Bologna. ${ }^{33}$ Die Nation hatte auch ihre eigenen Notare, statutarii und Sekretäre sowie ein amtliches Siegel und einen Schatzkasten, genannt archa oder capsa. ${ }^{34}$

Die ausländischen Studenten waren in Bologna im 15. Jahrhundert sehr willkommen, sie hatten eine gehobene Stellung und durften von vielen Vergünstigungen Gebrauch machen, die allen Bologneser Studierenden ab der Mitte des 13. Jahrhunderts bis ins 15. Jahrhundert zuteil wurden. ${ }^{35}$ Es ist leider nicht möglich, eine komplette Liste aller an der Bologneser Universität im Mittelalter und in der Renaissance immatrikulierten deutschen Studenten zu erstellen. Von 1289, dem Datum der ersten Matrikel an der Bologneser Uni-

27 Giosuè Carducci, Studio Bolognese (Bologna: Zanichelli, 1888), 24-25.

28 Vor allem die Professoren des Rechts mussten eine ordentliche punctatio librorum führen, was die Rektoren beaufsichtigen sollten. Cf. Manlio Bellomo, Saggio sull'università nell'età del diritto comune (Catania: Giannotta, 1979), 206-208. Bei den artes durfte man beliebige Bücher auswählen und eine punctatio librorum gab es nicht. Cf. Rose, Filippo Beroaldo der Ältere, 46.

29 Kibre, The Nations, 63.

30 Ibid., 30.

31 Ibid., 40, 42-43.

32 Ibid., 30.

33 Silvani, „Bologna, storica”, 123.

34 „Et in dicta capsa sigillum et omnia bona Nationis et divinum cultum spectantia debent conservari, statutorum liber et matricula penes procuratores," in Colliva, Statuta Nationis Germanicae, 141. Cf. Kibre, The Nations, 40, 63.

35 Pearl Kibre, Scholarly privileges in the Middle Ages: The rights, privileges and immunities of scholars and university at Bologna, Padua, Paris, and Oxford (Cambridge (Mass.): Mediaeval Academy of America, 1962), 52. 
versität, bis 1562, dem Datum der Umsiedlung der deutschen Nation nach Padua, schrieben sich in Bologna 4.368 Studenten dieser natio ein. Laut Finger studierten in den 322 Jahren „des Mittelalters" 6.594 Deutsche an der Bologneser Universität, ${ }^{36}$ allerdings ist es nicht klar, welche Grenzen der Forscher für das Mittelalter ansetzt.

Das Jurastudium, und erst recht eine Promotion, in Bologna konnten sich im 15. Jahrhundert nur die Abkömmlinge der reichsten Schichten leisten, ${ }^{37}$ von denen viele aus Deutschland und den jetzigen Gebieten Polens sowie aus Böhmen und Ungarn kamen. Im letzten Jahrzehnt waren allein fast 500 deutsche Jurastudenten in der natio germanica eingeschrieben. Unter ihren Mitgliedern waren in dieser Periode auch die Studenten der Medizin und der artes liberales, worüber die Libri segreti aus dem Erzbischofsarchiv, in denen alle Promotionen und Diplome verzeichnet sind, Aufschluss geben. ${ }^{38}$ Die meisten Absolventen wurden zu bekannten und bedeutenden Klerikern, die besonders im ius canonicum und im ius civile versiert waren. ${ }^{39}$ Viele von ihnen traten der von Luther begonnenen Reformbewegung bei. Unter den Bakkalaurei und Doktoren der natio germanica der Universität waren auch viele berühmte Wissenschaftler und Literaten, wie z. B. Nikolaus Kopernikus, Konrad Celtis, Konrad Peutinger, Rudolfus Agricola, Cornelius Henricus Agrippa und Ulrich von Hutten.

Das übliche Alter für den Beginn des Studiums war 15-16 (an der medizinischen Fakultät 18-20) Jahre. Das frühestmögliche Alter der Immatrikulation an einer Universität kann mit 14-15 Jahren angesetzt werden, unter Berücksichtigung der Tatsache, dass sich die jüngeren Studenten nicht unbedingt gleich für die Hauptkurse einschrieben, sondern für die Kurse aus dem Bereich trivium. ${ }^{40}$

Schon Odofred bezeichnete die Verbindung zwischen Studenten und Professoren als eine sehr herzliche. ${ }^{41}$ Malagola bemerkt, ${ }^{42}$ dass gerade die Studenten der natio germanica aller Fakultäten Ende des 15. Jahrhunderts einen wichtigen Platz an der Bologneser Universität einnahmen. In dieser Zeit - etwa von 1472 bis 1475 und von 1479-1505 ${ }^{43}$ - unterrichtete hier Filippo Beroaldo der Ältere. Gerade in diesen Jahren wurde ein erheblicher Zuwachs an ausländischen Studierenden verzeichnet. ${ }^{44}$ Einige kamen einzig und allein

36 Finger, Bologna und die Deutschen, 33.

37 Steffen, Die studentische Autonomie, 205.

38 Malagola, Monografie storiche, 267.

39 Silvani, „Bologna, storica”, 132.

40 Pini, „Discere turba volens”, 73.

41 Steffen, Die studentische Autonomie, 44.

42 Malagola, Monografie storiche, 266.

43 Rose, Filippo Beroaldo der Ältere, 18, 31.

44 Cf. Angaben über die Studentenzahlen für das Zivilrecht in den Jahren 1448-1497. Anna Laura Trombetti Budriesi, „L'esame di laurea presso lo Studio bolognese. Laureati in diritto civile nel secolo XV," in Studenti e università degli studenti. Dal XII al XIX secolo, a cura di G. P. Brizzi e A. I. Pini (Bologna, 1988), 174. 
mit der Absicht, ihn als Dozenten zu hören und bei ihm Student zu werden, wobei sie vorher einen Briefkontakt mit ihm oder ein Empfehlungsschreiben von einem seiner ehemaligen oder aktuellen Studenten hatten. Manche von ihnen wohnten bei Beroaldo zu Hause, denn das Unterbringen von Studenten zu Hause, was einen engen Kontakt mit dem Dozenten ermöglichte, war in Bologna schon seit dem 12. Jahrhundert üblich. ${ }^{45}$

Die Professoren und Doktoren genossen am studio bolognese auch eine gehobene Stellung, ihre collegii, die ihrerseits eine intrinsische Organisationsform innerhalb des Lehrkörpers darstellten, waren jedoch von den Universitäten der Studenten getrennt. ${ }^{46}$ Filippo Beroaldo wurde als an der Universität unterrichtender Bologneser Bürger aus der Stadtkasse bezahlt und gehörte zu den Professoren cum stipendio. Dies durften jedes Jahr nur zwei besonders geeignete, von dem jeweiligen collegium der universitates ausgewählte und von den riformatori dello studio bestätigten ordentliche Dozenten sein, ${ }^{47}$ die ihre Vorlesungen am Morgen (de mane) hielten. ${ }^{48}$ Beroaldo unterrichtete auch de sero und - nach der alten Bologneser Tradition ${ }^{49}$ - erteilte er Stunden auch bei sich zu Hause.

Im Vorwort seiner Gellius-Ausgabe erzählt Filippo Beroaldo von täglichen Hauslektionen, denen deutsche Studenten beiwohnten. Dieser Privatunterricht scheint auf den Wunsch seiner besten Studenten zurückzugehen, Beroaldo auch außerhalb des gewohnten Universitätsbetriebes noch zu hören. So schreibt er im Brief an seinen ungarischen Studenten Péter Váradi: Occupatum quoque occupant privatae lectiones, quarum sitientes sunt complusculi principes scholasticorum. Beroaldo war der einzige Professor, der eine innige Verbindung gerade zu den Studenten aus der natio germanica aufbaute. Dies bezeugt die Tatsache, dass Beroaldo fast alle seine Bücher den Vertretern dieser Nation gewidmet hatte. Darin folgten ihm später sein Kollege Giovanni Garzoni und sein Schüler Gian Battista Pio. ${ }^{50}$

Der zeitgenössische Biograph Beroaldos Bianchini berichtet von der großen Anzahl ausländischer Studenten, die durch dessen Vorlesungen nach Bologna gelockt wurden: Scholam eius clari genere fortunisque viri frequentarunt: ad quem audiendum undique ex longinquis regionibus confluebant. ${ }^{51}$ Der Bologneser

45 Besonders oft machten dies die Studenten der artes, manchmal wohnten mehrere von ihnen nach dem Prinzip hospitium seu schola bei einem Professor. Antonio I. Pini, "La presenza dello Studio nell'economia di Bologna medievale," in L'Università a Bologna, ed. Ovidio Capitani (Cinisello Balsamo (Milano): Silvana ed., 1987), 110. Cf. Pini, „Discere turba volens”, 79 , 82.

46 Kibre, Scholarly privileges in the Middle Ages, Fn. 124.

47 Pini, „Discere turba volens”, 89.

48 Kibre, Scholarly privileges in the Middle Ages, 41, 43, 44. Rose, Filippo Beroaldo der Ältere, 46-47.

49 Pini, „Discere turba volens”, 91.

50 Rose, Filippo Beroaldo der Ältere, 49 und 82 (zu Garzoni), 108-114 (zu Pio).

51 Zit. nach Eugenio Garin, La cultura filosofica del Rinascimento italiano: Ricerche e documenti (Florenz: Sansoni, 1961), 359, Fn. 2. 
Chronist Fileno dalle Tuate schreibt von 200 Schülern Beroaldos in Bologna. ${ }^{52}$ Über die Vielzahl seiner Schüler spricht Beroaldo 1494 voll Stolz in einem Brief an Poliziano, in dem er die Anzahl der Studenten mit 600 angibt: Testes sunt scholastici sexcenti... ${ }^{53}$ Girolamo Amaseo berichtet von 300 Studenten im Jahre 1493. Dies geht auch aus Beroaldos Brief (aus dem Jahre 1499) an seinen ungarischen Studenten Péter Váradi hervor. ${ }^{54}$ Aus Beroaldos Briefwechsel mit seinen Studenten geht ebenfalls eindeutig hervor, dass die litterae latinae, die er sowohl an der Universität als auch privat unterrichtete, der einzige Gegenstand seiner Lehr- und Kommentatorentätigkeit war.

Gerade dieses Gebiet interessierte die meisten Studenten aus den östlichen Regionen Europas. Die antike Literatur und Philosophie konnten sie in der Renaissance am besten an italienischen Universitäten erlernen. Der sich in den italienischen Städten rasant verbreitende Buchdruck ermöglichte den Nachschub an Lehrwerken - den Kommentaren zu lateinischen und griechischen Autoren, die stets aus der Feder der lehrenden Dozenten kamen.

Beroaldos deutsche Hörer erscheinen in seinem Gedicht Ad Germaniam: O Germania, muneris repertrix, // (...) // Abs te turba venit scholasticorum, // Hoc qui gymnasium excolunt, opimant. (...). Dieses Gedicht wurde als Anhang zur Rede Beroaldos De felicitate herausgegeben, die er einem seiner deutschen Schüler, dem Markgrafen Jakob II. von Baden (Jacobus Badensis), widmete. Ein anderer Schüler Beroaldos, Richard Graman (1465-1513), gebürtig in Trier, studierte in Italien in der Zeit von 1480 bis 1490. Nach seiner Rückkehr wurde er magister universitatis studii Treverensis in seiner Heimatstadt. Unter den deutschen Studenten findet man auch den Sohn eines berühmten deutschen Adelgeschlechts, Sigmund von Hohenlohe (1485-1534), 55 einen „,begabten deutschen Studenten aus einer sehr reichen adligen Familie", wie Beroaldo im Widmungsbrief des Gellius-Kommentars schreibt. Sigmund von Hohenlohe hatte gewiss engen und vertrauten Umgang mit Beroaldo, da er bei der Taufe von dessen Sohn Vincenzo, der ca. 1502 geboren wurde, zusammen mit dem Ungarn Mihály Kesserü (Michael Chesserius), ${ }^{56}$ den Beroaldo in dieser Zeit als seinen Freund bezeichnet, zugegen war.

52 Zit. nach Lodovico Frati, „I due Beroaldi,” in StudMemBologna 1911, 212 und Fn. 4: Bibl. Univ. Cod. 1438, f. 277v: „Erano in questa terra doxento scholari oltramontani per lui, che dopo la sua morte tutti se partino."

53 Omnium Angeli Politiani operum tomus prior (Paris: In aedibus Jodoci Badii Ascensii, 1519), f. LIII.

54 Garin, La cultura filosofica del Rinascimento italiano: Ricerche e documenti, 383, zit. aus dem MS Campori, App. 324 (Y. 2. 25), ff. $24^{\mathrm{v}}-27^{\mathrm{r}}$. Der Brief ist vom 20. Dezember, also vom 20. 10. 1499.

55 Cf. Ernst Friedländer und Carlo Malagola, Acta Nationis Germanicae Universitatis Bononiensis ex archetypis tabularii Malvezziani (Berlin: Typis et impensis Georgii Reimeri, 1887), 256, der Eintrag für das Studienjahr 1500.

56 Über ihn: Gedeon Borsa, „Bornemisza Pál megemlékezése Várdai Ferencről és a többi, Mohács előtti bolognai, magyar vonatkozású nyomtatvány," Irodalomtörténeti Közlemények 87 (1983), 48-58. 
In dieser Zeit bereitete Beroaldo die Gellius-Ausgabe für den Druck vor, und die Erinnerung an das Ereignis war noch frisch. Pate ${ }^{57}$ war ein anderer deutscher Student, Wolfgang de Hewen (Wolfgangus Hebenensis, Canonicus Treverensis). Der Letztere wurde 1504 Rektor der Universität in Freiburg. Unter den Angehörigen der natio germanica aus Deutschland waren der Adressat einer späteren Widmung Beroaldos, Marquardus vom Stein (? -1559), Sebastianus a Rotenhan aus Rentweinsdorf (1478-1532) aus Franken, Johannes von Kitzscher (? -1521/1539) aus Sachsen, Johannes Forderer alias Kühorn (? -1575) aus Mainz, später als Kammergerichtsassessor, dann als Professor für Recht an der Universität zu Mainz und schließlich als Kurmainzischer Kanzler tätig, Johannes Collauer (Collawer) (? -1508), ein Freund von Giovanni Francesco Pico della Mirandola und Konrad Peutinger (1465-1547), später kaiserlicher Sekretär in Ungarn und Kanonikus in Trier. Außerdem waren unter Beroaldos deutschen Studenten Dietericus a Werthern (1468-1536) aus Erfurt, später Berater des Kaisers Maximilian, Karls V. und des Königs Ferdinand, Thomas Wolff der Jüngere (? -1509), Eitelwolf vom Stein (? -1515), Johannes Rack aus Sommerfeld (Johannes Rhagius Aesticampianus) (14571520), der später vom Papst in Rom als Dichter ausgezeichnet wurde, in Mainz als Professor der Rhetorik und Ethik tätig war und 1512 die theologische Doktorwürde in Rom erlangte, Sigmund Gossinger aus Breslau, Vincenz Lang aus Freystadt (Eleutherius Longinus) sowie Jakob Locher (Juli 14711528), die zwischen 1490 und 1500 in Bologna studierten, und Henricus Johannes Novimagensis de Trai, der später den Druckerberuf ausübte und in Paris die Praefatio Plynii in libros Naturalis Historiae ex libro et ore Philippi Beroaldi castigata herausgab. ${ }^{58}$

Die Zahl der polnischen Studenten, die in Bologna ab dem 13. Jahrhundert immer präsent waren, war erheblich, so dass sie den dritten Platz nach den italienischen und deutschen Studenten hielten. Dazu zählen Paweł Szydłowiecki, Erazm Ciołek aus Krakau, Stanisław Ostrowski, Piotr Tomicki, der später zu den mächtigsten Männern Polens gehört hat, und Johannes Koquovicki, der in derselben Zeit wie Paweł Szydłowiecki in Bologna studierte. Beide waren adliger Abstammung und Freunde von Enrico Gaiado, der ihnen einige seiner Gedichte widmete, und gehörten zu den besten Jurastudenten der Bologneser Universität.

57 Konrad Krautter, Philologische Methode und humanistische Existenz. Filippo Beroaldo und sein Kommentar zum 'Goldenen Esel' des Apuleius (München: Fink, 1971), 18.

58 Gustav C. Knod, Deutsche Studenten in Bologna (Berlin: v. Decker, 1899), 611-612. gibt dieses Werk einerseits als einen Druck s. l. e. a. an, andererseits bestimmt er den Druckort als Paris und den Drucker als Jod. Badius: „Praefatio C. Plynii Se. in libros naturalis historiae Per Henricum Joannem Noviomagen. ex libro et ore Philippi Beroaldi castigata. Item eiusdem C. Plynii de hominum miseriis caput per eundem Henricum castigatum, s. 1. e. a." Die Ausgabe enthält laut Knod eine Vorrede: „Henricus Johannes Jodoco Badio.” Eventuell ist die von Knod gemeinte Person Heinrich von Neuß, der in Köln als Drucker tätig war und eine Ausgabe von Caii Plinii Secundi Praefationes duae im Jahre 1511 herausgegeben hat. 
Besonders engen und herzlichen Kontakt hatte Beroaldo mit seinen böhmischen Schülern, die regelmäßig nach Bologna kamen und Beroaldo sehr nah standen. Ihr Lehrer widmete ihnen viele seiner Schriften. Über seine Widmungspraxis spricht er selbst im Widmungsbrief der Schrift Heptalogos: ${ }^{.9}$ ...Nobilibus scholasticis transmontanis hoc genere libellos nuncupatim dicari consuevi, und im Vorwort zur Oratio proverbiorum, ${ }^{60}$ wo er die böhmischen Schüler als illustres nostri sectatores transmontani bezeichnet.

Beroaldo war sich der Wirkung bewusst, die die Bologneser Atmosphäre und die Universität auf die Studenten aus Böhmen, Ungarn, den heutigen polnischen Regionen und Deutschland hatte. Einer seiner böhmischen Schüler - er hielt sich in Bologna von 1475 bis 1482 auf - war Bohuslaw Hassenstein von Lobkowicz (Lobkowitz) (1462-1510), der zu einer alten adligen Familie gehörte. Bezeichnend für die Klärung der Frage der nationalen Angehörigkeit ist sein Bestreben, sich einen „Deutschen” zu nennen, obwohl er von den Böhmen als Böhme betrachtet wurde. ${ }^{61}$ Die meisten Studenten aus den oben genannten Landstrichen sprachen Deutsch und daher war ihre Zugehörigkeit zur natio germanica nicht geographisch, sondern auch sprachlich bestimmt.

$\mathrm{Zu}$ den besten Studenten Beroaldos zählten auch die Brüder Wladislaw von Wartenberg (Ladislav z Vartemberka) und Johannes von Wartenberg (Jan z Vartemberka) (ca. 1480-1508), ${ }^{62}$ beide Söhne des böhmischen Adligen Sigmund von Wartenberg. Sie hielten sich in Bologna mit Sicherheit in den Jahren 1497 bis 1500 auf. Peter (Petr z Rožmberka) (? -1523) und Ulrich (Oldřich z Rožmberka) ${ }^{63}$ (1471-1512) von Rosenberg, Angehörige eines alten, reichen und berühmten Adelsgeschlechtes, frequentierten ebenfalls Beroaldos Vorlesungen in Bologna und genossen seine Gastfreundschaft. Ferner ist als Student Beroaldos Martin Mareş oder Martin von Krumlow ${ }^{64}$ bekannt, Sohn einer reichen Familie aus Böhmen, der Bruder des bei der schon oben genannten Familie Rosenberg als Erzieher und Sekretär beschäftigten Alexander von Krumlow. Er wurde von seinem Schwager Václav z Rovného nach Bologna zu Filippo Beroaldo geschickt, studierte dort vom 18. Juni 1487 bis zum 5. Juni 1493 und erwarb den Doktortitel. Václav z Rovného war mit der Schwester von Martin Mareş, Elizabeth, verheiratet. Dieser Václav hatte einen direkten

59 Heptalogos (Bologna, 1498), f. aii.

60 Orationes et praelectiones (Paris, 1511), ff. XLVII -XLVIII.

61 Bohumyl Ryba, „Filip Beroaldus a čeští humanisté,” in Městské museum v Českých Budějovicích, zpráva za léta 1932-1933, České Budějovice, 1934.

62 Frati, „I due Beroaldi,” 217; Friedländer und Malagola, Acta Nationis Germanicae, 250; Knod, Deutsche Studenten in Bologna, 611-612. Cf. auch: Garin, La cultura filosofica del Rinascimento italiano, 367.

63 Friedländer und Malagola, Acta Nationis Germanicae, 233 und 235.

64 In der Oratio proverbiorum (Bologna, 17. Dezember 1499, GW 4142) erwähnt B. diesen böhmischen Schüler. Martin Mareş wurde später der Magie beschuldigt und starb 1490 in Böhmen. 
Kontakt mit Ulrich von Rosenberg, bei dem er ab dem Jahre 1475 Sekretärsaufgaben erfüllte. Er erwarb später den Adelstitel, wurde Erzbischof und lebte bis zum Anfang des 16. Jahrhunderts, was anhand eines an ihn gerichteten Briefes von Bohuslav Lobkovicz anzunehmen ist.

$\mathrm{Zu}$ den böhmischen Studenten gehörte auch der Sohn des böhmischen Adligen Benedictus Weitmühl Christophorus von Weitmühl (Krištof z Veitmíle) (? -1507), dem Beroaldo im Jahre 1499 seine Oratio proverbiorum widmete. Im Vorwort bemerkt Beroaldo, dass Christophorus aus der jüngsten Generation seiner böhmischen Studenten war, der haud magno sane intervallo nach den ersten herausragenden Böhmen Ulrich von Rosenberg, Johannes Wartenberg und Martin Mareş nach Bologna kam. Auch Arnošt Sleinic (Ernst de Schleinitz) (? -1548) war einer der böhmischen Studenten Beroaldos, der im Eintrag für das Jahr 1501 registriert ist. Diesem Studenten widmete Beroaldo die im Jahre 1504 erschienene Ausgabe der Commentarii belli Gallici Caesars. Manche Briefe aus dem Briefwechsel Beroaldos mit den böhmischen Humanisten, darunter Martin Mareş, Václav z Rovného und Ulrich von Rosenberg, befinden sich in der Prager Handschrift. ${ }^{65}$ Es ist nicht auszuschließen, dass in den weiteren MSS aus dieser Zeit, die in der Tschechischen Republik aufbewahrt werden, andere wertvolle Zeugnisse der Verbindung der tschechischen Humanisten mit der Bologneser Universität im Allgemeinen und mit Filippo Beroaldo im Besonderen noch zu finden sind.

Unter den ungarischen Studenten Beroaldos waren der angesehene ungarische Humanist Péter Váradi (um 1450-1501), der 1480 Erzbischof von Bács-Kalocsa (archiepiscopus Colocensis) wurde. Ihm widmete Beroaldo seinen Apuleius-Kommentar. Péter Váradi unterstützte seinerseits mehrere ungarische Studenten Beroaldos: Fülöp Csulai Móré (Philippus Cyulanus, ?-1526) und Mihály Gibárti Kesserü (?-1534). ${ }^{66}$ Tamás Bakócz (um 1442-1521) kam aus Krakau nach Bologna und wurde dort im Jahre 1494 immatrikuliert. Im Herbst des Jahres 1503 schickte er auch zwei Neffen, János und Pál, nach Bologna, die Beroaldo bei sich zu Hause unterbrachte. Unter den ungarischen Schülern, die wahrscheinlich von Bakócz nach Bologna geschickt wurden, gibt es auch einen gewissen Stefan Brodarics (Stephanus Pannonius cognomento Brodarius Zagroviensis), der später ein königlicher Diplomat und Bischof von Pécs (Fünfkirchen) und Vác (Waitzen) und berühmt als Historiker wurde. ${ }^{67}$ Osvaldo de Ungheria, O. P. (Osuardus q. alterius Osuardi de Hungaria, ord. Praedicatorum) taucht in den Registerlisten der Studenten in Bologna am 27. April 1498 auf. Er könnte auch ein Student Beroaldos gewesen sein. ${ }^{68}$ Pia-

65 Es handelt sich um das MS XB 13 aus dem Museum regni Bohemiae.

66 Garin, La cultura filosofica, 377. Der Autor stützt sich auf die Angaben aus dem Brief B's an Váradi aus dem Jahre 1499 aus dem MS Campori, ff. 22 $22^{\mathrm{r}}-24^{\mathrm{v}}$.

67 Für den Hinweis darauf bedanke ich mich bei Péter Ekler von der Abteilung Alte und seltene Drucke der National Széchényi Library.

68 Celestino Piana, O. F. M. Ricerche su le Università di Bologna e di Parma nel secolo XV (Firenze: Quaracchi, 1963), 213. 
na hat ihn als Osvaldo de Quinqueecclesiis (Pécs [Fünfkirchen], Ungarn) identifiziert. Im Juni 1498 hat das Generalkapitel von Ferrara ihm den Magistertitel zuerkannt. Anhand des Briefwechsels und weiteren Schriftzeugnissen sollte unter anderem die Rolle von Augustinus Moravus Olomucensis untersucht werden, der als Freund Beroaldos womöglich weitere begabte und betuchte Studenten zu ihm schickte. In Ungarn öffnet sich noch ein weites Feld für die Handschriftenforscher, die die Verbindung von ungarischen Humanisten nach Bologna belegen können.

Unter den slowenischen Studenten ist nur einer bekannt, dessen Verbindung zu Beroaldo noch nachgewiesen werden soll. Laut Piana wurde ein Pietro de Landis da Capodistria am 12. Dezember 1495 in die Matrikeln eingetragen. Er wird dort als vir eximiae sapientiae Petrus q. ser Francisci de Landis de Iustinopoli, provinciae Istriae bezeichnet. ${ }^{69}$ Seine Magistermütze sowie den Doktorkranz hat er nach der Prüfung von Stephanus de Francia im Bischofspalast erhalten.

Die Studenten der natio germanica brachten einen anderen "methodisch-wissenschaftlichen Zugang", ${ }^{70}$ einen neuen Wissenschaftsgeist, ein neues Verständnis der Wissenschaft und ihre neuen Rechtskenntnisse nach Hause mit, die sie in Italien, unter anderem auch an der Bologneser Universität, erworben hatten. Das neue „rhetorische Ideal” der italienischen Humanisten, die unablässige Bedeutung der Öffentlichkeit, ${ }^{71}$ und das römische Recht, das durch seine für das Reich bedeutende Stellung eine übernationale Gestalt einnahm, wurden somit auf den fruchtbaren Boden in den nördlichen und östlichen europäischen Ländern übertragen. ${ }^{72}$

Nach Beroaldos Tod - sei es auch ein Zufall gewesen - verliert die Bologneser Universität ihren Ruhm und ihr ausgesprochen hohes Niveau. Bologna wird zu einem von vielen Studienstandorten Europas, und viele an den berühmten Universitäten Italiens ausgebildete Doktoren unterrichten in ihrer Heimat. Im Jahre 1562 siedelt die Deutsche Nation für zehn Jahre nach Padua um. ${ }^{73}$ Die deutsche Nation in Bologna durchlebte dementsprechend ihre Blütezeit in Padua und verlor ihre Bedeutung und Anziehungskraft in Bologna. ${ }^{74}$

Allerdings trugen die Alumni der Bologneser Universität den humanistischen Geist in alle Ecken Europas weiter. Sie gründeten sodalitates, wurden zu poetae laureati gekrönt, unterrichteten an den Universitäten und regten das wissenschaftliche Leben in ihren Ländern an. Es war das hohe Gut der frei-

69 Ibid., 205.

70 August Buck (Hrsg.), Die Rezeption der Antike: Zum Problem der Kontinuität zwischen Mittelalter und Renaissance (Hamburg: Hauswedell, 1981), I, 29-30.

71 Ibid., 29-30.

72 Colliva, Statuta Nationis Germanicae, 70.

73 Malagola, Monografie storiche, 291.

74 Emilio Costa, Gli atti delle due nazioni germaniche nello studio di Padova (Firenze: Tip. Galileiana, 1913), 315 
heitlichen humanistischen, in der Antike verwurzelten Bildung, das aus Italien wie eine frische Luft nach Norden und Osten gebracht wurde und das die reformativen Bewegungen der darauf folgenden Zeit für sich nutzten. Die eigentlichen Träger dieser neuen Bewegungen waren die ehemaligen Studenten italienischer Universitäten, die den hohen Wert der humanistischen Studien auf ihre Lebensverhältnisse zu übertragen begannen. 



\section{MATYÁŠ FRANCISZEK BAJGER}

\section{Discovering Relationships between Jan Filipec and Humanism}

Just a quick glance at the life of Jan Filipec (Filipecz, Pruis) ${ }^{1}$ will convince the reader that he cannot have been untouched by contemporary Humanism - in Buda, Olomouc or Várad (Oradea, RO) when going on his diplomatic travels all across Europe or through his contacts with the social elite. Like some other humanists, he had not come from a wealthy family, but worked his way through to the most influential classes and circles, where we meet lovers of poetry, Antiquity and ancient Christianity. Although it was usual to obtain a humanistic education studying in Italy, especially among church dignitaries, Filipec only attended a local school in his native Moravian town Prostějov. ${ }^{2}$ The guesses about his studies in Italy ${ }^{3}$ are controversial, as an expensive stay at an Apennine university was unconceivable for the son of a burgher and a secretary of the local aristocracy. Filipec's frequent diplomatic journeys to Italy gave him a considerable opportunity to encounter humanist culture. Especially a longer stay in Rome in 1482-1483 offered him a genuine chance for this. After his return, while having dinner with the royal couple in Buda, he spoke about the "humanitas" he had acquired in Rome "without taking a pause".

1 Cf. Antonín Kalous, "Jan Filipec v diplomatických službách Matyáše Korvína," Časopis Matice moravské 125, no. 1 (2006): 7. Rudolf Grieger, Filipecz (München: R. Trafenik, 1982).

2 Cf. Prothasius z Boskovic and Janus Pannonius. Ivo Hlobil, “Morava a uherská (italská) renesance za Matyáše Korvína," Časopis Matice moravské 110, no. 2 (1991): 327. Peter Wörster, "Breslau und Olmütz als humanistische Zentren vor der Reformation," in Humanismus und Renaissance in Ostmitteleuropa vor der Reformation, ed. W. Eberhard (Köln: Böhlau, 1996), 221. For the education of Filipec cf. invitation speech of Prague Univ. rector Koranda (IX/1488), published in Manuálník M. Vácslava Korandy, ed. J. Truhlář (Praha: Královská česká společnost nauk, 1888), 130.

3 Josef Macek, “K dějinám Olomouce na konci 15. století," Okresní archív v Olomouci 1987 (1988): 56.

4 Kalous, “Jan Filipec v diplomatických službách...": 15-16. 


\section{Filipec's writings}

The ground of Filipec's literary activity is based on letters ${ }^{5}$ that in their form, style, logical structure and content demonstrate numerous signs typical of the humanistic production of the second half of the $15^{\text {th }}$ century. Elegant courtly expressions or clear composition belonged to the higher social culture and letter writing practices. Filipec contributed widely to the development of chancery writing in its style and fine minuscule. His letters are free of bombastic and pompous forms, lacking completely themes from antique Greece and Rome. Clear language, as well as some superfluous praises and salutations cannot be judged as exclusively humanistic, as they belong to the common diplomatic-pragmatic style.

The Czech tractate Proti kaczierzom a pikhartom y proti wssem bludnym (meaning "against heretics and pikharts and all misbelievers") is in the strict sense the only literary work written by Filipec, we assume. The anonymous work is preserved among other Franciscan treatises against Czech Brethren in a manuscript dating back to $1511 .{ }^{6}$ Undoubtedly, its author was a Franciscan friar. In the initial part, the author noted that he had decided to write the Tractate in Uherské Hradiště, when he was sent to the king in Hungary. Thus, he can be identified as Jan Filipec, who was in contact with Vladislaus II Jagiello and in his last years lived in Hradiště. At the beginning of the treatise, a salutation "nejmilostivější pane" (= graceful lord) appears several times. Hereafter, the reader is addressed in the $2^{\text {nd }}$ person plural. The whole content of the tractate points towards obedience to the Church and the Pope and ignores all other confessional and dogmatic issues, which renders its character political rather than religious. Its Czech language suggests a lay readership. We may assume that the Tractate was created in connection with the Diets (Landstag) in July and August 1508 in Bohemia and Moravia. King Vladislaus sent Filipec with Stanislaus Thurzó to these congresses to announce and espouse a prohibition of Czech and Moravian Brethren, as later confirmed by the royal "St. Jacob's Mandate". 7 This hard task against noblemen needed the

5 Correspondence with Vilém II of Pernstein in Archiv český. Díl XVI, ed. J. Kalousek (Praha: Královská česká společnost nauk, 1897), no. 17, 28, 29, 30, 31, 307, 344, 347, 405, 517e, 660. Listář Bohuslava Hasištejnského z Lobkovic, ed. J. Truhlář (Praha: Česká akademie, 1893), 173 (no. 143). Cf. an overview by Josef Macůrek, "Humanismus v oblasti moravsko-slezské a jeho vztahy ke Slovensku...," in Humanizmus a renesancia na Slovensku v 15.-16. storočí, ed. L. Holotík, A. Vantuch (Bratislava: Slovenská akadémia vied, 1967), 338-341.

6 National Library of the Czech Republic, XI.E.1.

7 Martin Rothkegel, Der lateinische Briefwechsel des Olmützer Bischofs Stanislaus Thurzó (Hamburg: Lit, 2007), 36-37. Filipec had to present the desires of Utraquists to the Pope, cf. Staré letopisy české z rukopisu kř́žovnického, ed. F. Šimek, M. Kaňák (Praha: SNKLHU, 1959), 308, 331. Jan Dubravius, "Historiae Bohemicae commentarii," Liber 32, in Rerum Bohemicarum antiqui scriptores..., ed. M. Freher (Hanoviae: Claudius Marnius, 1602), 262. Grieger, Filipecz, 441-446. Filipec was present at earlier Diets in 1477 in České Budějovice too. He negotiated for the unity of the Church and defended an anti-Hussite discourse written by Franciscans at Diets in 1496. 
appropriate preparation of arguments. Filipec's discourse ordaining consensus in society and confession was mentioned by the representative of the Czech Brethren faith Jan of Zierotin the Elder, by the humanist historian Joannes Michael Brutus, as well as in later Franciscan historiography. ${ }^{8}$

Accrediting the Tractate to Filipec, we get a slightly different image of him than in diplomatic and political activities. It is written as a common coeval religious controversial and polemic treatise. The writer proposes an argument and consecutively substantiates it with "authorities," most frequently from the Holy Scriptures. He frequently quotes Church Fathers, and there are a few references to scholastic literature, like Thomas Aquinas or Haimo of Halberstadt. Filipec presents his creditable knowledge of Christian scriptures that were accessible to the author in the libraries of Franciscan convents. ${ }^{9}$ The strong emphasis on Patristics, in other words antique Christianity, is unsurprising and typical of contemporary humanists. If the author had some education in theology, he would certainly use many more scholastic and medieval treatises that he had been familiarised with during studies. The Church Fathers were probably closer to Filipec and could be more applicable for controversies with noblemen at Diets. The first part concerning arguments on why heretics perform evil (dazed by anger, carnal luxury, consecration to Devil) still has the clear nature of late medieval literature. Filipec had a wider purview of Christian teaching than Augustinus Olomucensis. In his printed letter against Waldensians, Augustin refers only to Jerome from among postBiblical authors. However, he does not hesitate to quote from Pythagoras, Epicure, Virgil, Origen, or Greek mythology. Filipec's tractate is free of the usual defamations of heretics, which are typical of Augustine and the humanists, as well as contemporary Franciscan authors. ${ }^{10}$ The reason of this trait of speech for Diets could be diplomatic rather than ideological.

\section{The books of Filipec and his library}

If we compare Filipec with his bishopric predecessors János Vitéz and Prothasius z Boskovic ${ }^{11}$ and consider his broad contacts, we may assume he

8 Grieger, Filipecz, 455-456. Brutus János Mihály, Magyar história: 1490-1552, ed. Ferencz Toldy (Pest, 1863), 94-95. Vigilius Greiderer, Germania Franciscana..., t. 1 (Oeniponte: J. Th. de Trattnern, 1777), 745.

9 Greiderer, Germania Franciscana, 743. Vincze Bunyitai, A váradi püspökség története alapitásától a jelenkorig (Nagyvárad, 1883), 320.

10 Amedeo Molnár, "Protivaldenská polemika na úsvitu 16. století," Historická Olomouc 3 (1980): 160-161. František Šmahel, “Die Anfänge des Humanismus in Böhmen," in Humanismus und Renaissance in Ostmitteleuropa..., 196. Josef Truhlář, Humanismus a humanisté v Čechách za krále Vladislava (Praha: Česká akademie, 1894), 112, 152. Other Franciscan antiUtraquist discourses are included in the same volume as that described Filipec's work.

11 Klára Csapodi-Gárdonyi, Die Bibliothek des Johannes Vitéz (Budapest: Akadémiai Kiadó, 1984), passim. Matthias Corvinus und die Bildung der Renaissance, ed. E. Gamillscheg, B. Merisch 
had his ample library. Filipec cared for his residencies, as the bishopric palace in Várad (Oradea), the Moravian castle Vyškov or his house in Olomouc, ${ }^{12}$ yet he did not reside in them for most of his life, so he did not have the opportunity to build a representative book collection. ${ }^{13}$ Some former book ascriptions to him have appeared erroneous, as the manuscript De re aedificatoria libri X by Leon B. Alberti owned by Augustinus Olomucensis, ${ }^{14}$ or the Commentarii in Asinum aureum by Filippo Beroaldo. Filipec possessed a Latin translation of Avicenna's Canon, including the De viribus cordis and a rhymed Cantica de Medicina. ${ }^{15}$ He acquired this incunable print between 1484 and 1490, and the topic corresponds to his interests in medicine. ${ }^{16}$ He did not keep the book for a long time; he donated or sold it in Wrocław before 1499. The convolute volume includes Filipec's handwritten note, partly in verse, which differs from humanistic eulogies:

Forma, favor populi, feruor iuvenilis, opesque

Surripuere tibi, noscere quid sit homo.

Post hominem vermis, post vermem fetor et horror,

Sic in non hominem vertitur omnis homo.

Dum hec fili legeris, memento te cito moriturum. Recole eciam districti iudicis sententiam: A qua nemini licentia appellandi conceditur pondera sevissimorum hostium funesta accusatorum: Insuper eternarum penarum acerbitatem.

I[ohannes] e[piscopus] waradiens. A to gest prawa prawda. ${ }^{17}$

The proverbs were taken from Meditationes de cognitione humanae conditionis commonly assigned to (Pseudo-)Bernardus Clarevallensis ${ }^{18}$ and are supplemented with an appeal in his own words that shortly fits the

(Wien: Österreichische Nationalbibliothek, 1994), 44-49, 51-52, 58-59, 61-62, 65, 71-72, 7677, 82-82, 85-86. (No. 3-8, 11, 19, 22, 26, 30, 37, 46, 50). Hlobil, “Morava a uherská (italská) renesance...," 328. Ágnes Ritoók-Szalay, "Der Humanismus in Ungarn zur Zeit von Matthias Corvinus," in Humanismus und Renaissance in Ostmitteleuropa vor der Reformation, 168.

12 Antonín Kalous, "Církev a biskupství," in Dějiny Olomouce 1, ed. J. Šmeral (Olomouc: Univerzita Palackého, 2009), 234. Cf. Archiv český XVI, 532 (no. 713). Bohumil Samek, “Jan Kapistrán a Jan Filipec v Olomouci," Vlastivědný věstník moravský 62, no. 2 (2011): 120-126.

13 Edith Hoffmann, Régi magyar bibliofilek (Budapest: Magyar Bibliophil Társaság, 1929), 86 et seq. Csaba Csapodi, "Filipec (Pruisz) János váradi és olmützi püspök könyvei," Magyar Könyvszemle 83 (1967): 243-249. Csaba Csapodi, “Die erhalten gebliebenen Bücher des Johann Filipec (Pruis)," Gutenberg-Jahrbuch 1975: 338-340.

14 Zemský archiv v Opavě, Library of Chapter in Olomouc, CO 330. Cf. Árpád Mikó, “Az olomouci Alberti-Corvina - Augustinus Olomucensis könyve," Müvészettörténeti Értesítő 34 (1985): 65-72. Árpád Mikó, "Il ‘De re aedificatoria' e la corte di re Mattia Corvino," Nuova Corvina 16 (2004): 71-76.

15 Venezia, 1483 and 1484; GW 3119, GW 3129. Sächsische Landesbibliothek Dresden, Ink. 3122(1), Ink 3320(1)

16 Archiv český XVI, 13-18. (no. 28, 31). Ivo Hlobil, “Visual art," in Humanism and the Early Renaissance in Moravia (Olomouc: Votobia, 1999), 140-141. Pavlína Foltýnová-Mikulcová, "Jan Filipec, diplomat ze sklonku středověku," Dějiny a současnost 21, no. 1 (1999): 14.

17 Cf. Csapodi, “Filipec (Pruisz) János...," 248.

18 Caput II. Published in Patrologia Latina. Tomus 184, ed. J.-P. Migne (Paris, 1862), col. 490. 
meaning of the consequent paragraphs in Meditationes. Filipec wrote the text when he was already a Franciscan or at least was thinking about this life orientation. The former lover of vogue and beauty, who could also be influenced by humanists, confesses here the dangers of wealth together with his personal conversion to eternity. Another book owned by Filipec is the Rule and Testament of St. Francis written on parchment, maybe partially by Filipec himself, and illuminated by Franciscan illuminators under his supervision. According to the Baroque Franciscan historian Bernard Sannig (†1704), Filipec might have copied the manuscript during his noviciate in Wrocław in 1492 and donated it "for the pleasure of his beloved friars" in a convent in Bechyně in 1499, but the calligraphic rotunda script in the first part of the volume rather suggests the work of professional Franciscan scribes. ${ }^{19}$ An initial with Filipec's coat-of-arms indicates that the Rule was decorated by Franciscans as a courtesy gift for him, but later he returned it to the use of the Order.

A set of liturgical books for Várad (Oradea) associated with Filipec stood somewhere between a private and bishopric collection. He donated these books to the Cathedral in Várad even before he abandoned this church office. ${ }^{20}$ It seems he preferred the exchange and circulation of books according to readers' needs rather than collecting them in a library. ${ }^{21}$ Filipec requested a guardian of his nephew Vilém II of Pernstein to pay for books that he had acquired. In a letter sent from Wrocław on $22^{\text {nd }}$ September 1493 (about a year after his religious vow), ${ }^{22}$ Filipec asked his close friend for an unspecified sum of money without giving any data about the titles, authors or topic of the books. He had chosen them by his own will and for his own needs, without sharing recommendations of worthy titles. He just asked his friend, whom he had known for more than 20 years from the royal chancellery, ${ }^{23}$ for some generous payment. Their relationship did not lead to sharing their literary or reading experiences. Filipec used some poetic formulations in the letter, but

19 Cf. more about the circumstances on the creation of the manuscript in Matyáš F. Bajger, "Bratr, někdy biskup Jan Filipec (1431-1509) a knihy okolo něj," Problematika historických a vzácných knižních fondů Čech, Moravy a Slezska 19 (2010), 141-143. http://www.vkol.cz/data/ soubory/import/konf19/Bajger.pdf. Karel Beránek, “Památka na Jana Filipce v Státním ústředním archivu v Praze," in Ars baculum vitae, ed. V. Vlnas (Praha: Národní galerie, 1996), 52-55. The manuscript is in the National Archives (Prague), Řad františkánů, Inv.no. 660.

20 Petrus Ransanus, Epitome rerum hungaricarum (Viennae: R. Hofhalter, 1558), f. VII. Ransano describes Filipec as a bishop of Várad (Oradea, RO) in the present tense, but the book donation is referred to in the past perfect as a past event.

21 Cf. similar case of János Vitéz: Csapodi-Gárdonyi, Die Bibliothek des Johannes Vitéz, 59, 73.

22 Archiv český XVI, 14-18. (no. 31).

23 Ivo Hlobil, “Jan Filipec a studia Jana z Kunovic," Vlastivědný věstník moravský 42, no. 3 (1990): 403-404. 
ritual dedications or praises coupled with a suggested swapping of books typical among humanists ${ }^{24}$ are missing.

As an administrator of the Olomouc bishopric, Jan Filipec did not participate in founding the first Moravian printing office in Brno, whose production was centred on the demands of the book market, making no efforts at disseminating antique or humanist literature, which is valid also for Thuróczi's Chronica Hungarorum from $1488 .{ }^{25}$ (Fig. 1.)
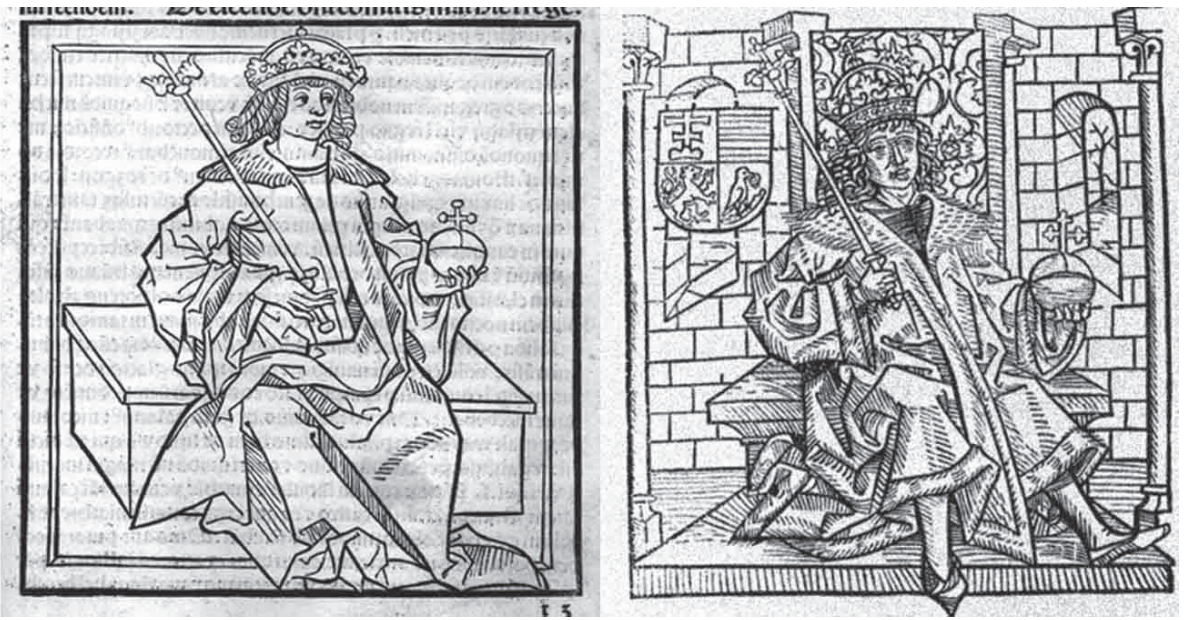

Fig. 1. Comparison of woodcut portraits of Matthias Corvinus from Thuróczi's Chronica Hungarorum. On the left side the edition from Brno, on the right the print from Augsburg (both from 1488).

On the other hand, book printing was familiar to Filipec. An edition of the Breviarium Olomucense in Venice in $1484^{26}$ might be the outcome of his travels through Italy. He expressed his attitude in a foreword to Missale Olomucense printed in Bamberg in $1488 .^{27}$ Filipec refers to book printing here as "ars pollens" and this potency relies on the promise it offered of unifying divergences in liturgical practices due to diverse transcriptions of handwritten missals and rituals. ${ }^{28}$ Thus, the later Moravian bishops S. Thurzó and

24 Šmahel, "Die Anfänge des Humanismus in Böhmen," 198. Csapodi-Gárdonyi, Die Bibliothek des Johannes Vitéz, 167.

25 GW M14782, ISTC it00360000. For a more detailed analysis about the originators and circumstances of the 1488 edition of the Chronica in Brno, see Bajger, "Bratr, někdy biskup Jan Filipec...," 132-134.

26 ISTC ib01172900, GW 5414.

27 The foreword of $3^{\text {rd }}$ May 1488, Olomouc. ISTC im00677000. H-C 11337. Cf. Kamil Boldan, “Bamberské vydání olomouckého a pražského misálu (1488 a 1489)," Problematika historických a vzácných knižních fondủ Čech, Moravy a Slezska 8 (1999): 13-20.

28 Cf. Dana Martínková, "Ohlas vynálezu knihtisku v naší latinsky psané literatuře," in Kniha a knihtisk v českých zemích od husitství do Bílé hory, ed. J. Polišenský, F. Šmahel (Praha: Academia, 1970), 151-167. 
S. Pavlovský supported printing mostly for the circulation of books for church liturgy and religious debates. ${ }^{29}$

\section{Relationships to humanists}

In Buda, Filipec must have met the humanistic elite around the court, including such personalities as Antonio Bonfini, ${ }^{30}$ Janus Pannonius, Galeotto Marzio, Augustinus Olomucensis, Jan Šlechta and others. Filipec is likely to have met János Vitéz, his predecessor in Várad (Oradea) in matters of Church and state administration and they might have shared some ideas about society, morality or politics, possibly in the spirit of Humanism. However, not everybody around the royal court in Buda was so excited about Humanism (e.g. the Franciscan Gabriel Rangoni ${ }^{31}$ ).

Filipec corresponded with Bohuslav Hasištejnský z Lobkovic, as they knew each other from political circles from about $1500 .{ }^{32}$ Bohuslav used Filipec's good contacts with the royal court for solving his dissensions with vassals and praised him for his ability to abandon Church dignities after the unsuccessful election of Bohuslav to bishop of Olomouc. They were both joined by their personal relationships to Franciscan Observants. In matters related to antique books or literary activities, Bohuslav preferred to write to other personalities, like Augustinus Olomucensis, Viktor Cornelius ze Všehrd or Jan Šlechta. Like Filipec, Augustinus was Bohuslaus's mediator at the royal court, but in their correspondence, we also find notes on their poetic writings, books by Plutarch or hope in Jupiter's help..$^{33}$

A possible relationship between Filipec and Augustinus Olomucensis can be inferred from Augustin's work Catalogus (Series) episcoporum olomucensium, where Filipec is praised for his merits, diligence and career. In adjacent chapters describing Prothasius z Boskovic and Stanislaus Thurzó, Augustin added a list of contemporary European humanists close or known to him. Such a list is missing in the text about Filipec, which suggests that he did not raise any humanistic associations in Augustin's mind. Supposedly, Ctibor Tovačovský z Cimburka, the son of John, whom Filipec had served as

29 Ondřej Jakubec, “Olomoučtí biskupové jako renesanční mecenáši?," in Pro arte. Sborník k poctě Ivo Hlobila, ed. D. Prix (Praha: Artefactum, 2002), 267.

30 Bonfini got to know Filipec when writing his Rerum Hungaricarum decades from 1488. In the introduction, he mentions Filipec wrongly as a member of an old Czech family, in the $4^{\text {th }}$ Decade, his burgher parentage is already remarked correctly. Cf. Macurrek, "Humanismus v oblasti moravsko-slezské...," 341.

31 Petr Hlaváček, "Im Dienst der Christenheit: Der Franziskaner und Diplomat Gabriel Rangoni...," in Hofkultur der Jagiellonendynastie und verwandter Fürstenhäuser, ed. U. Borkowska, M. Hörsch (Ostfildern: Jan Thorbecke, 2010), 107-118.

32 Listár̆ Bohuslava Hasištejnského z Lobkovic, 76, 143 (no. 63, 143).

33 Ibid., 149-150, 171-172. (no. 114, 141). 
a secretary, met Filipec in Hungary in $1468 .{ }^{34}$ In the year 1490, Filipec left his precious dinnerware and other jewels at Ctibor's castle Tovačov, which had nothing to do with releasing his possessions before joining Franciscans. ${ }^{35}$ Whether they both discussed issues on Renaissance art, or if Filipec used a castle library in Tovačov is shrouded in mystery. ${ }^{36}$ During his journey to France in the year 1487, Filipec might have met Hieronymus Balbus and persuaded him to write a panegyric De laudibus bellicis regis Pannoniae addressed to Corvin. ${ }^{37}$

We have no evidence that Filipec was a member of a humanistic society. The oldest one in Central Europe, associated with C. Celtis, was founded in Vienna in 1497,38 but in those years, Filipec seriously contemplated his religious way in the Franciscan Order, which fundamentally differed in its spirituality and values from societies of humanists. Filipec might have had closer relations with ecclesiastical confraternities, in which he actively participated. ${ }^{39}$

\section{Supporting students}

Jan Filipec supported students. Thus, we can see his closer ties with education. The regular help he gave his nephew Jan z Kunovic at university in Leipzig should not be a surprise due to prevalent nepotism. ${ }^{40}$ Filipec paid for his nephew's higher than usual formal and informal fees and expensive clothing. Jan z Kunovic might have continued his studies in Bologna using money from

34 Historia Fratrum Bohemicorum. National Library of the CR, XVII.F.51b, p. 264. See Antonín Kalous, "Itinerář Jana Filipce (1431-1509)," Acta Universitatis Palackianae Olomucensis, Historica 34 (2008): 17-44.

35 Archiv český XVI, 9-10. (no. 21). Filipec did not have to hand over his properties due to accepting Franciscan poverty. As the Franciscan friar, he bought a village Lešany from Ctibor Tovačovský. Cf. Kalous, "Itinerář Jana Filipce," 34-35. Ivo Hlobil, “K stavebněhistorické analýze tovačovského zámku," in Morava na prahu nové doby, ed. F. Hýbl (Přerov: Muzeum Komenského, 1995), 110-112.

36 Cf. Hlobil, "Morava a (uherská) italská renesance...," 329, 337-338. Václav Pumprla, "Poznámky k zámecké knihovně Ctibora Tovačovského z Cimburka," In: Morava na prahu nové doby. Sborník príspěvků z konference konané 22. - 23. června 1994 u př́ležitosti úmrtí Ctibora Tovačovského z Cimburka (Přerov: Muzeum Komenského, 1995), 67-70.

37 Gilbert Tournoy, "The literary production of Hieronymus Balbus in Paris," GutenbergJahrbuch 53 (1978): 70-77.

38 Winfried Eberhard, "Grundzüge von Humanismus und Renaissance," in Humanismus und Renaissance in Ostmitteleuropa vor der Reformation, 1-28. Franz Machilek, "Konrad Celtis und Gelehrtensodalitäten, insbesondere in Ostmitteleuropa," ibid., 137-156.

39 In Várad (Oradea, RO), he was a member of Fraternity of Holy Spirit that supported orphans. See Bunyitai, A váradi püspökség..., 315. In 1482, he became a member of Confraternitas S. Spiritus in Hospital of H. Spirit in Rome. See Antonín Kalous, "Spor o biskupství olomoucké," Český časopis historický 105, No. 1 (2007): 15.

40 Hlobil, "Jan Filipec a studia Jana z Kunovic," 403-404. 
his uncle, but without his direct influence. Yet, Jan z Kunovic did not gain a good reputation among humanists. ${ }^{41}$

Another student sponsored by Filipec in Kraków was Valentin, called Vulcanius, suggesting that his real family name might have been Schmidt or Kovár. He was from Olomouc and could be identical with Valentin, son of Wenceslaus, who matriculated at Kraków University in the 1503 winter semester. $^{42}$ In the year 1506, thanks to this support, Vulcanius acquired a printed book Commentarii a Philippo Beroaldo conditi in Asinum aureum Lucii Apulei. ${ }^{43} \mathrm{He}$ might have purchased the Commentary on the basis of a recommendation by some Czech humanists who met Beroaldo personally. ${ }^{44}$ Vulcanius studied the book deeply and added multiple notes and glosses on the topics discussed in the text and on other subjects like astrology, as well as including proverbs. He was a fan of humanistic ideas. On the first printed page with Beroaldo's dedication, Vulcanius expressed in his own hand his thanks and praise to his two patrons and supporters - Filipec and Jan V Thurzó, the former University rector and bishop of Wrocław. Vulcanius also painted Thurzó's coat-of-arms in an empty woodcut medallion. ${ }^{45}$ The whole unprinted opposite page is dedicated to Filipec. The main part is a coloured pen drawing with Filipec's coat-of-arms (signs of bishoprics in Várad and Olomouc in quarters, while his personal sign in inescutcheon) decorated with a laurel wreath around it. ${ }^{46}$ (Fig. 2.) Below the coat-of-arms, Vulcanius wrote thanks and typical humanistic verses glorifying Filipec, probably on the occasion of his $75^{\text {th }}$ birthday:

Ad Reverendissimum in Christo patrem ac dominum d. Joannem // Episcopum Olim Waradiensem etc. Gratiarum actio

Dii tibi dent canos longeui Nestoris annos,

Dii tibi Mathusalem virida serta senis,

Dent tibi et Elysias, animarum premia, Valles

41 Truhlár̆, Humanismus a humanisté..., 102. Antonio Bonfini, Rerum Ungaricarum decades (Francofurti, 1581), 637.

42 "Walentinus Wenceslai de Olmucz" in Register of the University: Metryka Uniwersyteto Krakowskiego z lat 1400-1508. Tom I, ed. A. Gąsiorowski et al. (Kraków: Societas Vistulana, 2004), 603.

43 Venezia, 1501. The described volume is in Książnica Cieszyńska, Cieszyn, T III 31.

44 Bohumil Ryba, "Filip Beroaldus a čeští humanisté," in Zpráva o činnosti městského musea v Č. Budějovicích za léta 1932 a 1933 (České Budějovice: Městské museum, 1934), 1-39. Truhlář, Humanismus a humanisté..., 13, 101-104.

45 "Me, suum sibi foecit, Valentinus Vulcanius Olomutius, patrociniis auxistis, Rmi D. Epi. Joannis Waradiens., ac Mri d. Joannis Thurzonis patronorum suorum, decoriter, comiter, gaudialiter fovet." The same hand and black ink wrote most of the glosses in the volume. Another type of Valentin's notes also appears in the whole book and was written using violet ink.

46 The higher quality of this painting indicates work by a professional artist. The signs of Olomouc and Filipec are distorted here. Cf. Samek, "Jan Kapistrán a Jan Filipec v Olomouci." Josef Pilnáček, Staromoravští rodové (Vídeň: J. Pilnáček, 1930), 91. 
Post resides annos, post residesque dies

Inclite pro meritis presul, pietateque proque

Tantis officiis muneribusque hiis.

At the time when Valentin Vulcanius wrote this, Filipec had been a Franciscan for fifteen years. Considering his subsidies to a residence in Várad (Oradea), his concern about liturgical rules, engagement in confessional issues, as well as founding and enlarging churches and convents, we may assume that Filipec's Christian commitment was serious. We do not know if Filipec ever read this text; obviously the book of Commentaries did not belong to him. The next provenience of this book in 1586 points to a priest in Strúbro (Bohemia). Vulcanius became the rector of St. Thomas Church in Mohelnice near Olomouc, to which in his testament he left some of his other volumes. ${ }^{47}$

Filipec was evidently connected with universities in Prague, Vienna and Paris, but these contacts were probably rather brief, forming a part of courtesies on his diplomatic journeys serving other purposes. ${ }^{48} \mathrm{He}$ also supported studies in the Franciscan Order. ${ }^{49}$

\section{Art and architecture}

Filipec's diplomatic journeys, connected with numerous artistic gifts from Hungary and back, were the best chance for him to get acquainted with contemporary Renaissance art. ${ }^{50}$ The sources praise the quantity and value of these donations, but give no information about their style or details of their form. A rich set of paraments, vessels, jewels and books Filipec had collected remained in Várad (Oradea); he donated others to churches in Buda, Várad and elsewhere, or distributed among his relatives, mostly his nephew Valentinus called Lupus (Vlk), and friends, when he was entering the Order. ${ }^{51}$ The already mentioned dinnerware set that he left in Tovačov could be associated with rich banquets, but not strictly "humanistic" ones, as we know that representative dining was required in higher society from Antiquity up to his times. The style of the set probably does not represent Filipec's own taste as it may have been donated to him as a present. Filipec did not avoid contemporary popular trends in art at all. The red marble gravestones of his brother Mikuláš of Prostějov (†1477) in Steyr, as well as of his father Filip of

47 National Museum Library in Prague, XII D 11.

48 Kalous, “Jan Filipec v diplomatických...," 17, 23.

49 Letters of Franciscan Pavel z Moravy addressed to "Jan" (Brno, spring 1485) - National Library of the CR, Cheb 6/18, fol. 80.

50 Cf. Kalous, “Jan Filipec v diplomatických...," 31.

51 Bonfini, Rerum Ungaricarum decades, 638. Bunyitai, A váradi püspökség..., 320. Tomáš Měštánek, Biskup Jan Filipec (1431-1509) a středoevropská politika (Zlín: Krajská Knihovna F. Bartoše, 2003), 107-111. 
Prostějov and brother-in-law Duchek z Bydžova a Kunovic (†1485) in the Olomouc cathedral were commissioned by Filipec, following the trends in the Renaissance. ${ }^{52}$

The merits of Filipec in building were considerable. He "decorated" Moravian castles in Vyškov and Mírov, provided for the erection of the All Hallows' Augustinian Church in Olomouc, had the Olomouc Cathedral repaired and the Várad castle rebuilt. ${ }^{53}$ Nonetheless, these architectonic elements got lost during later wars or reconstructions. The architecture associated with his predecessor in Olomouc Prothasius z Boskovic was still entirely Gothic, and the minimal surviving architectonic details in Filipec's house in Olomouc are also Late Gothic in style. ${ }^{54}$ Buildings constructed during his regular stage are better preserved. He was active in the reconstruction of Franciscan churches and convents in Olomouc, Jawor and Wrocław, built a new house in Uherské Hradiště and encouraged the construction of convents in Skalica, Bechyně and Kamenz. Their clear Late Gothic style with no Renaissance elements does not differ from other Franciscan temples and houses of the period. Filipec continued the Franciscan tradition and might have used the services of builders of his predecessor in Olomouc Prothasius, as suggested by the similar features of the churches they had built. ${ }^{55}$ The vault and wall decoration and paintings of churches in Jawor and Olomouc are very similar to the decoration of the manuscripts described below. ${ }^{56}$ The style of these paintings does not testify any influences of Renaissance themes. The figures are more dynamic than the ones in older works, which is however true for the general development of Czech and Silesian art.

52 Hlobil, “Morava a uherská (italská) renesance...," 330. A. von Pantz, "Die Grabdenkmale der Stadtpfarrkirche zu Steyer," Jahrbuch der k. k. heraldischen Gesellschaft "Adler", N. F. 21 (1911): 107.

53 Grieger, Filipecz, 10, 69-70, 170. Augustinus Olomucensis, Catalogus episcoporum Olomucensium (Vienna, 1511), fol. B5v.

54 Hlobil, "Morava a uherská (italská) renesance..., " 328. Bohumil Samek, “Jan Kapistrán a Jan Filipec v Olomouci. Olomoucké marginálie - 1.," in Vlastivědný věstník moravský (Brno: Muzejní a vlastivědná společnost), 63/2 (2011), 121-125.

55 Zuzana Křenková, “K nejstarším dějinám a stavebnímu vývoji kláštera františkánů observantů v Olomouci," Vlastivědný věstník moravský 62, no. 2 (2010): 152-169. Petr Hlaváček, Čeští františkáni na přelomu středověku a novověku (Praha: Academia, 2005), 92.

56 Jakub Kostowski, “Programy obrazowe oraz funkcje wyposażenia bernaryńskich świątyń na Śląsku w póżnym średniowieczu," in Bernardyni na Śląsku v póżnym średniowieczu, ed. J. Kostowski (Wrocław: ATUT, 2005), 206-207. Ivo Hlobil, "Úvodní glosy k nástěnné malbě pozdní gotiky a rané renesance na Olomoucku," in Od gotiky k renesanci III., Olomoucko, ed. I. Hlobil, M. Perůtka (Olomouc: Muzeum umění, 1999), 406-429. 


\section{Manuscripts}

The first group of manuscripts linked to Jan Filipec is connected to the cathedral in Várad. The Renaissance style of illuminations of the so-called János Simor Pontificale conforms to other codexes created for or by Matyas Corvin in the royal illuminator's office in Buda. ${ }^{57}$ Textually, the Pontificale originates from the times of Emperor Charles IV, but without Czech provenance as another person mentioned in the text is the Hungarian King Louis I. ${ }^{58}$ The Pontificale assigned to him by Corvin does not show much about Filipec's affections and tastes. The other liturgical books Filipec prepared for the Church of Várad date back to 1485-1490, and are traditionally called Zalka Antiphonary, but they originally contained at least a Gradual and Sequences for the Mass too, and they represent a different artistic style. ${ }^{59}$ Their liturgical texts correspond to the rite of Várad, but with some Czech elements. Their musical notation is presumably also Czech. Their illuminations have many similarities with other manuscripts by painters in the Prague circle. Hardly could they have been commissioned by anyone other than Filipec. The decorative style is comparable to the usual Late Gothic style characteristic of Bohemia.

Filipec's artistic taste may be deduced from the Corvin Graduale that Filipec had probably brought from his 1487 journey to France as a gift to the King. ${ }^{60}$ The codex was originally a Franciscan work, furnished with the typical four-line musical notation. Its decoration, illuminated in or around Angers, is a mixture of regular political-military themes with the hot threat faced by Hungary and Europe - fighting the Turks. The style reflects a mixture of Italian Renaissance and Flemish and French Late Gothic elements in Western Europe. The textual level of the Graduale is monastic, but the paintings could not have been produced without Filipec's direct influence. The virtue of these illuminations is based on their contextual relationship to Psalms but shifting the meaning from ancient topics to up-to-date politics.

Another group of liturgical manuscripts linked to Filipec was created among Franciscan Observant friars. Franciscans restricted superfluous book illuminations, e.g. at the Provincial Chapter in Wrocław in 1495, which Filipec

57 Esztergomi Főszékesegyházi Könyvtár, Cod. Simor Ms 26. Gyöngyi Török, "Pontificale des Bischofs Johannes Filipecz," in Matthias Corvinus und die Renaissance in Ungarn 1458-1541 (Wien: Amt der Niederösterr. Landesregierung, 1982), 433-435. Hoffmann, Régi magyar bibliofilek, 122-124.

58 Ilona Berkovits, “Az Esztergomi Ulászló-graduale," Magyar Könyvszemle 65, no. 4 (1941): 342-353.

59 Egyházmegyei Könyvtár, Győr. Cf. Körmendy Kinga, "Az ún. Zalka Antiphonale töredékei,” Zenetudományi dolgozatok 1988: 33-41.

60 Budapest, Országos Széchényi Könyvtár, Cod. Lat. 424. Elisabeth Soltész, "Zur Herkunft des Corvin-Graduals und zur Ikonographie seiner Miniaturen," Magyar Könyvszemle 84, no. 4 (1968): 334-342. Zoltánné Soltész, A Mátyás-Graduale (Budapest: Helikon, 1980), 19. Bajger, "Bratr, někdy biskup Jan Filipec...," 120-123. 
also attended ${ }^{61}$ Franciscan sources report liturgical manuscripts "written by" Filipec for convents in Wrocław, Uherské Hradiště and Skalica. ${ }^{62}$ Evidently, he was not the scribe or painter himself, but was certainly active in acquiring money for the parchment and binding, and organised the whole process performed by other friar-artists in Wrocław, Olomouc and Jawor. Their style and notation is based on older Franciscan codexes continuing older CentralEuropean traditions, also influenced by Hungarian friar-painters, but already from the early flowering of Franciscan Observants after 1450, without any of Filipec's impact. ${ }^{63}$ The novelty in several of them was the new round script humanistica rotunda, previously unknown in the Czech lands. (Fig. 3.) Using this scripture, which was imported from Italy and easier to read, could be influenced by Filipec's "humanitas" as well as importation of Italian Observants active in Central Europe.

\section{Personality}

Jan Filipec's extraordinary competences in diplomacy, his character, culture and personal relationships to others cannot be questioned, as can be derived from his activities and descriptions of his personality. ${ }^{64}$ His rhetorical skills and literary competencies cannot be doubted, but he used them for political and diplomatic affairs rather than for the encouragement of literature, art and culture.

A deeper insight into his personality might be derived from motivations of his entry to the Franciscan Order. Opinions that the already aged Filipec looked for peace and quiet from politics, he was scared of his blunders in diplomacy or was overloaded by his conscience cannot be upheld. Filipec's

61 Lucius Teichmann, Die Franziskaner-Observanten in Schlesien vor der Reformation (Breslau: Antonius-Verlag, 1934), 51. Petr Hlaváček, “Čeští františkáni, vzdělanost a knižní kultura v 15./16. století," Theologická revue 72, no. 1 (2001): 49.

62 Antonius Gánóczy, Episcopi Varadienses fide diplomatum concinnati (Vienna: J. M. Gerold, 1776), 419-500. Bunyitai, A váradi püspökség..., 319. Handwritten notes by Jan K. Vyskočil in National Archives Prague, Řád františkánů, Inv. No 2473, fasc. 8. The manuscripts were originally in the Franciscan Monastery in Uherské Hradiště, since 1950 they have been deposited in the Research Library in Olomouc with shelf-marks: M IV 4, M IV 7, M IV 3, M IV 5. Vševlad Gajdoš, "Z dejín františkánskej knižnice v Skalici” in Skalica v minulosti a dnes, ed. J. Buchta et al. (Bratislava: Obzor, 1968), 224-232.

63 Barbara Miodońska, Malopolskie malarstwo ksiażkowe 1320-1540 (Warszawa: PWN, 1993), 146-150. Milada Studničková, "Conscriptum per Fratrem Mathiam de Rehtz," in Františkánství $v$ kontaktech s jiným a cizím, ed. P. Hlaváček (Praha: Univerzita Karlova, 2009), 210-220. Wiesław F. Murawiec, "Początki biblioteki konwentu Krakowskiego...," Folia Historica Cracoviensia 7 (2000): 103.

64 Bonfini, Rerum Ungaricarum decades, 638. Ransanus, Epitome rerum hungaricarum, fol. VII. Greiderer, Germania Franciscana I, 743. 
"change of mind" or "repentance" is described by Antonio Bonfini in his Rerum Hungaricarum Decades:

En stultam mortalium sapientiam, en irritos hominum labores, en perquam vanum ... Valeant haec omnia, quae me mei ipsius immemorem effecere, ... quae me ad divini numinis vultum nunquam suspicere permisere ... quo me (ni fallor) ab omni mortalitate jam asseram.

These are other phrases Bonfini assigned to Filipec, where he praises poverty, Christ as a servant, following him to the cross, or shows his disdain for fragile terrestrial life. These words are more likely to be made up by Bonfini than real talk by Filipec as the resigning prelate and knight. ${ }^{65}$ Yet, they meet the personality of Filipec and suggest that they knew each other well and were in personal or mail contact around the years 1490-1492 when Bonfini was finishing his $4^{\text {th }}$ Decade. ${ }^{66}$ As a Franciscan friar, Filipec was still active among the most powerful men of society. ${ }^{67} \mathrm{He}$ had known and liked the Franciscan Order many years before his religious vow. ${ }^{68}$ His attached note on the fleetingness of the world and aversion to fashion in his book by Avicenna, as well as his profuse endorsement of the Order indicate a positive motivation based on the recognition of the ephemeral nature of wealth and profane endeavours. This inclination was not exceptional among humanists. The Franciscan Observants claiming poverty as a way to Heaven were favoured by other noble churchmen like Prothasius $\mathrm{z}$ Boskovic or Bohuslav Hasištejnský. ${ }^{69}$ We know that Czech humanists were not oriented towards ancient philosophy and poetry only. They had grown up in Christianity and also promoted ancient religious literature, primarily the works of Church Fathers. ${ }^{70}$

\section{Conclusion}

If we perceived Humanism of the $15^{\text {th }}$ and $16^{\text {th }}$ centuries just as a revival of ancient Greco-Roman culture, literature and mythology, there would be no place for Jan Filipec. In his known activities, there are no signs of promoting

65 Bonfini, Rerum Ungaricarum decades, 682-683. This first printed edition of Bonfini's Chronica prepared by Joannes Sambucus and printed in Frankfurt in 1588 does not mark Filipec's statement with quotes or other punctuation marks or by typeface as appears in most later editions. Nevertheless, the quote can be still determined by changing the $3^{\text {rd }}$ person (he) to the $1^{\text {st }}(\mathrm{I})$ in the text.

66 Gerhard Rill, "Bonfini, Antonio", in Dizionario biografico degli italiani. Vol. 12 (1971). Accessed March 11, 2015. http://www.treccani.it/biografie/.

67 Kalous, “Itinerář Jana Filipce," 35-38. Grieger, Filipecz, 369-375, 410-462.

68 Petr Hlaváček, "Retrospektiva dějin františkánského kláštera Čtrnácti sv. Pomocníků v Kadani v 15. a 16. století," Ústecký sborník historický 2001: 79-106.

69 Truhlár. Humanismus a humanisté, 123. Hlobil, "Visual art," 140-141.

70 Šmahel, “Die Anfänge des Humanismus in Böhmen," 201. 
ancient culture, nor attempts to promote universal ethic ideas. ${ }^{71}$ The classification of Filipec as a humanist changes with a wider concept of Humanism oriented at a rationalistic attitude to life with its problems and circumstances. The Renaissance of ancient values of Christianity could coalesce with the restoration of Antique culture generally, particularly among persons studying in Italy or otherwise connected to the Apennine Peninsula, such as Bohuslav Hasištejnský, Stanislav and Jan Thurzó or Jan Roth. ${ }^{72}$ Such ideas put emphasis on personal faith and relationship with God and divert from ecclesiastical activities, which keystone was based on material possessions. They stand closer to other orientations of Christianity like moderate Hussitism in Bohemia or the Modern Devotion in the Netherlands.

Jan Filipec cannot be perceived as a typical humanist zealous to restore ancient culture including related activities such as book collecting. His rhetorical skills and ability to negotiate were renowned, but cannot have been influenced by his personal stance to Humanism. His interconnection to the Church linked him more with Christian tradition than the heritage of antique Greece and Rome. This was demonstrated by his thinking as well as in fine arts, when several Renaissance elements acquired in Hungary or Italy penetrated the traditional Gothic style. He was not among the propagators of the new style in matters of Renaissance book decoration either.

71 Eberhard, "Grundzüge von Humanismus und Renaissance," 4.

72 Tomáš Baletka, “Osobnost olomouckého biskupa Stanislava Thurza (1497-1540)," Historická Olomouc 17 (2009): 57-64. Peter Wörster, “Der Olmützer Humanistenkreis unter Stanislaus Thurzó," in Studien zum Humanismus in den Böhmischen Länder, ed. H. Harder, H. Rothe (Köln: Böhlau, 1988), 39-61. Rothkegel, Der lateinische Briefwechsel des Olmützer Bischofs..., 36-37. Cf. a dialog between Filipec and Roth, where Roth claimed he would never descend from the position of bishop to the lower state of monk. Filipec demurred that he would if "the devil had subjugate him as an ape and daze him." See Grieger, Filipecz, 373 and 407. 



\title{
EMŐKE RITA SZILÁGYI
}

\section{Johannes Roth und Augustinus Moravus Olomucensis*}

\author{
1. Einleitung
}

Augustinus Moravus Olomucensis verfasste sein erstes poetologisches Werk, den halbdramatischen Dialogus in defensionem poetices, um $1492^{1}$ und versah ihn mit einer Widmung an den Breslauer Bischof Johannes Roth (1426-1506). Neben seinem Onkel Andreas Ctiborius (†1496) war Johannes Roth allem Anschein nach der erste Mäzen des Olmützers. Die Fragen, wann sie sich kennengelernt haben und was für Kenntnisse eigentlich über dieses Mäzenatentum zu erwerben sind, werden in meinem Beitrag ausführlich behandelt. Nach der Schilderung der Laufbahn des Johannes Roth und seines Mäzenatentums, werden in diesem Beitrag Augustinus' Bekanntschaft mit Johannes Roth sowie ihre gemeinsamen Verbindungen untersucht und dargelegt.

\section{Johannes Roth und sein Mäzenatentum}

\subsection{Johannes Roth}

In Hinblick auf die Laufbahn des Johannes Roth beziehe ich mich vor allem auf den Verfasserlexikonartikel von Franz Josef Worstbrock und auf die Schriften von Agostino Sottili und Karlmann Tangl. ${ }^{2}$ Die Herkunft und die frühe Schulbildung des Johannes Roth sind unklar; spätestens Mitte der 1440er Jahren begann er mit dem Rechtsstudium in Padua und setzte es in Bologna fort. In die studia humanitatis vertiefte er sich ungefähr ab 1450 in

* Hier möchte ich mich bei Frau Zsuzsanna Cziráki, Herrn Péter Ekler und Johannes Klaus Kipf für ihre freundliche Hilfe bedanken. Ich widme diese Arbeit Herrn Franz Josef Worstbrock, dem Experten des Themas.

1 Der Dedikationsbrief an Johannes Roth ist auf den 12. November 1492 datiert, jedoch ist der Dialog erst am 24. März 1493 erschienen, vgl. Rukovet' humanistického básnictví, Vol. I. (A-C), ed. Antonin Truhlár et al. (Praha, Academia, 1966), 113. Die kritische Ausgabe s. Karel Svoboda, Augustini Olomucensis Dialogus in defensionem poetices (V Praze: Nákladem České akademie věd a uměni, 1948). Von nun an: Dialogus.

2 Franz Josef Worstbrock, "Johannes Roth," in Verfasserlexikon Bd. 8., 1992, 269-275. Von nun an: Worstbrock, "Johannes Roth,“; Karlmann Tangl, „Johann I. Rott (1468-1482), " in Reihe der Bischöfe von Lavant, ed. Karlmann Tangl (Klagenfurt: Johann Leon Verlag, 1841), 175-197. 
Rom bei Lorenzo Valla. In diesen Jahren trat er in den Dienst der Kurie und wurde zum Priester geweiht. 1452 nahm er an der Kaiserkrönung Friedrichs III. teil, worüber er in dem an Ludwig Rad adressierten Brief berichtet. ${ }^{3}$ Vermutlich von Eneas Silvius Piccolomini empfohlen, wurde er 1456 Sekretär des Ladislaus Postumus und schrieb noch in diesem Jahr eine Leichenrede anlässlich des Todes von dem Königsonkel Ulrich von Cilli. ${ }^{4}$ Der vorzeitige Tod des jungen Königs unterbrach die Karriere von Roth, weshalb er beschloss seine juristischen Studien in Padua fortzusetzten. Nachdem er Doktor des Kirchenrechts geworden war, begann er seine geistliche Laufbahn: 1464 wurde er Pfarrer in St. Georgen im Attergau, ab 1460 Domdekan in Passau und ab 1466 Domdekan in Breslau. 1465 trat er in den Dienst des Kaisers in Wien ein und wurde bald Protonotar, dann Kanzler; mittlerweile wurde er nach Rudolf von Rüdesheim Bischof von Lavant. 1479/1480 setzte er sich im Streit um die Besetzung des Salzburger erzbischöflichen Stuhls für König Matthias statt des Kaisers ein und so geriet er in den Dienst des ungarischen Königs, von dem er im Jahre 1482 den Breslauer Episkopat erhielt. Nach dem Tod Matthias' konnte er jedoch seine Pfründen behalten und bewahrte seine Macht und seinen Einfluss auch unter der Regierung des Wladislaus II. Allem Anschein nach hatte er Sinn für Politik: er stand jeweils in der Gnade des Herrschers, unabhängig von dessen Herkunft.

$\mathrm{Ab}$ den 1450er Jahren korrespondierte er schon mit Poggio Bracciolini, Eneas Silvius Piccolomini, Johannes Vitéz de Zredna, Albrecht von Eyb, Gregor Heimburg, Ludwig Rad und Johannes Tröster. In Trösters Dialogus de remedio amoris (verfasst 1454) wird Roth als Anreger des Werkes benannt und tritt als Mitglied des Wiener Humanistenkreises auf, ${ }^{5}$ dessen zentrale Persönlichkeit Eneas Silvius Piccolomini war. Zu diesem Kreis gehörten viele literarisch begabte Personen wie zum Beispiel Johannes Tröster, der weltberühmte

3 Die Ausgabe s. Agostino Sottili, „Der Bericht des Johannes Roth über die Kaiserkrönung von Friedrich III.," in Deutsche Handwerker, Künstler und Gelehrte im Rom der Renaissance, ed. Stephan Füssel and Klaus A. Vogel (Pirckheimer Jahrbuch, Bd. 15/16), (Wiesbaden: Harrasowitz Verlag, 2000), 46-100.

4 Die Ausgabe der Oracio funebris Iohannis Rot de casu illustris comitis Ulrici de Cilia und zu den Cillis s. Marija Wakounig and Primož Simoniti, Humanismus bei den Slovenen: slovenische Humanisten bis zur Mitte des 16. Jahrhunderts (Zentraleuropa-Studien, 11), (Wien: Verlag der Österreichischen Akademie der Wissenschaften, 2008), 289-293.

5 So wurde Roth im Prolog der Redaktion A benannt: „Exigebat proximis nunc his Iulii diebus per longam nonminus sententiis quam verbis comptam epistolam mei et tui amans Augustensis ille Iohannes Rot [Hervorhebung E. R. Sz.] - is enim, ut eum pernoscas plenius, qui perfamiliarem iocundum humanum insuper et urbanum se nobis, dum Rome eramus, reddidit - sibi tamquam re expertus aut veteribus amicis perdoctus, quid sentirem de amore, ut scriberem, an et ego ex Vulcano Venereque natum immitem iratum cecum alatum deorum hominum atque ferarum domitorem deum, aut optabile honestum bonum vel vulgare detestandumque vitium et an ut accusabile [malum] ita et evitabile eradicabileque sit, si et fixum sedet, amorem dicam." Bis dem Erschein der kritischen Ausgabe muß man die Quellenausgabe der Sankt Pöltener Hs. (Red. A) zitieren, s. Raymundus Duellius, Miscellaneorum, Quae Ex Codicibus Mss. Collegit, Vol. I, (Augsburg, 1723-1724), 228. 
Dichter Janus Pannonius, Johannes Vitéz de Zredna, der selbst seine Episteln zusammensammeln und edieren ließ, der Astronom Georg Peuerbach, der neben seinem Interesse für die Sternkunde auch Aeneis-Vorlesungen hielt, und so weiter und so fort. Zu dieser Zeit interessierte sich Roth ebenso intensiv für literarische Fragen: 1453/1454 korrespondierte er mit Gregor Heimburg über den Vorrang von Rhetorik oder Jurisprudenz. Als Schüler Vallas lobte Roth die Eloquenz, während er die Jurisprudenz kritisierte. Vermutlich wegen dieser Schriften wurde er Vorbild für die späteren Autoren, die die studia humanitatis verteidigen wollten, wie z. B. Hermann Schedel ${ }^{6}$ oder Augustinus Moravus.

In der Widmung des Dialogus in defensionem poetices betonte Augustinus, dass die römische Literatur (litterae) in ihrem Zeitalter bei Roth zu Hause zu sein scheint:

\begin{abstract}
Verum enimuero quum diligentius ipse mecum pertractarem, cuinam istud qualecunque libelli est nuncuparem, uariosque ob eam rem cum Germaniae principes, tum Boemiae, etiam Pannoniae, Morauiae et Slesiae, quibus aliqua bonarum litterarum et antiquitatis cura uideretur repeterem, tu mihi praeter ceteros, Praesul Reverendissime, occurristi apud quem litterae romanae hac tempestate nostra tamquam domicilium quoddam sibi constituisse uidentur. Ommitto enim res tuas praeclare cum domi tum foris gestas, ommitto quanta modestia, doctrina, sanctitate pro tua pontificia potestate apud Lauantinos olim, nunc autem in sacratissima Vratislauiensi katedra excellueris (haec enim alterius temporis dictionisque existimo), uel ob id maxime quod ea ibi cum multis communia putem: at litterarum peritia multarumque optimarum disciplinarum cum dignitate fastigium tantum in te splendoris superadiecisse uidentur, ut non temere quis iudicauerit rerumne abs te bene gestarum, an litterarum gratia superior existimandus sis. ${ }^{7}$
\end{abstract}

Dieses Lob war allerdings superlativisch und die Widmung galt eher als Lobrede, da sich nämlich die literarische Tätigkeit des Bischofs - abgesehen von der Leichenrede auf Ulrich von Cilli - vorwiegend auf die Briefschreibkunst beschränkte. Dazu schrieb Franz Josef Worstbrock: „Doch er war kein Schriftsteller von Geblüt, auch kein Gelehrter, strebte vielmehr von früh an zu Amt, Einfluß, Einkommen, die sich der gewandte Schreiber und Jurist vom Fürstendienst versprach. ${ }^{\prime 8}$ Das ist an seinem Schaffen leicht wahrzunehmen: Seine brieflichen Abhandlungen stammen aus den 1450er-1460er Jahren, prinzipiell aus der Zeitspanne vor seinem Karriereaufstieg. Nachdem er 1465 in der kaiserlichen Kanzlei in Wien angestellt worden war, schien er mit den literarischen Tätigkeiten aufgehört zu haben. Ähnlich wie Johannes Vitéz de

6 Worstbrock, ,Johannes Roth,“ 274.

7 Dialogus 13.

8 Worstbrock, „Johannes Roth,“ 271. 
Zredna war Roth eher großzügiger Mäzen als tadelloser und denkwürdiger Schriftsteller.

\subsection{Mäzenatentum des Johannes Roth}

Normalerweise wird aus den Widmungen oder aus Hinweisen von Briefen die Schlussfolgerung gezogen, dass der Adressat der Mäzen des Verfassers war. Wolfgang Leiner definierte die Dedikation im Historischen Wörterbuch der Rhetorik so: „Er kann Ausdruck eines Dankes, Gegenstand einer Bitte sein und ist meistens als Lobrede auf den Empfänger konzipiert; er kann Anlaß zu einer poetologischen Auslassung oder zu einer Verteidigung des Autors und seines Werkes sein. ${ }^{\prime 9}$

Zum literarischen Mäzenatentum des Johannes Roth sind die Widmungen die wichtigsten Quellen. Heute sind drei Widmungen an Johannes Roth bekannt: Als Erster widmete ihm Ludovico Lazzarelli (1447-1500) neun Stücke seines Carmen bucolicum. Die einzige Handschrift, in der die Eklogen überliefert wurden, gehörte allem Anschein nach Roth. Die Eklogen sind undatiert, aber man kann ihre Entstehungszeit annähernd bestimmen: Der Prolog klingt folgendermaßen: „Ludovici Lazarelli Poete laureati oratio ad D. Io. Rothum. Reticum seu Germanicum. Imperialem Secretarium nec non Laventensem Episcopum pro sequentis operis oblatione (c. 1. inc. Infula cui sacram radiantibus aspera gemmis. “10 Roth bekleidete sein Kanzleiamt seit 1465, wurde erst 1468 Bischof von Lavant und folglich sollte die Widmung zwischen 1465 und 1468 verfasst worden sein. Außerdem wurde Lazzarelli 1468 vom Kaiser Friedrich III. mit der Dichterkrone gekrönt, ${ }^{11}$ die er mutmaßlich dem Einfluss von Roth verdankte.

Neben Moravus und Lazzarelli gibt es noch einen Autor, der seinen Hymnus an Maria mit einer Widmung an Roth versah, der aber in den biographischen Schriften über Roth nicht erwähnt wird. Den Briefwechsel des Konrad Celtis lesend, habe ich den dritten Beförderten gefunden, der 1491 in Korrespondenz mit Celtis stand. Das Figurengedicht des Johannes Langer von Bolkenhain († vor 1505) entstand nach Gustav Bauch unter dem Einfluss von Hrabanus Maurus' De laudibus sanctae crucis erst nach $1503 .{ }^{12}$ Langer studierte

9 Wolfgang Leiner, „Dedikation,“ in Historisches Wörterbuch der Rhetorik, Vol. 2., ed. Gert Ueding (Tübingen: Max Niemeyer Verlag, 1994), 453.

10 Paul Oskar Kristeller, Studies in Renaissance Thought and Letters, III. Vol., (Roma, 1993), 218.

11 Vgl. John Flood, Poets Laureate in the Holy Roman Empire: A Bio-bibliographical Handbook, L-R, Vol. 3., (Berlin-New York: De Gruyter, 2006), 1104-1105.

12 Johannes Klaus Kipf, "Johannes Langer von Bolkenhain," in Deutscher Humanismus, Verfasserlexikon 1480-1520, Bd. II. L-Z, Lieferung 1., ed. Franz Josef Worstbrock (Berlin-New York: Walter de Gruyter, 2009), 27-31. Vgl. Gustav Bauch, Geschichte des Breslauer Schulwesens vor der Reformation (Codex diplomaticus Silesiae 25), (Breslau, 1909), 222. Anm. 2. Das Gedicht ist auch in der Sammlung Extemporalitates Wratislavie von Sigismund Buchwald erhalten, die von über 100 Carmina zusammengestellt wurde, vgl. Johannes Klaus Kipf, „Sigismund 
an der Universität Krakau und wurde spätestens 1485 Altarist im Dom und in der Kirche St. Maria Magdalena in Breslau. 1489 protestierte er in einem Traktat gegen die von König Matthias erlassene Steuer, dann wurde er durch ein Dekret des Johannes Roth zum collector derselben Steuer ernannt. ${ }^{13}$ Die Ausführung des Mandats ist nur durch den Tod des Königs verhindert worden. Keine Daten sind darüber vorhanden, wie der Konflikt zwischen Roth und Langer gelöst wurde, aber die Dedikation zeigt, dass sie sich schließlich versöhnt haben.

\section{Johannes Roth und Augustinus Moravus Olomucensis}

Die Kontaktaufnahme mit Roth war für Augustinus Moravus zweifellos vorteilhaft. Aufgrund der Widmung des Dialogus in defensionem poetices vermutete Ralf Georg Czapla (und wenn ich mich nicht irre, wurde dieses Konzept überall angenommen), dass Augustinus „mit finanzieller Unterstützung seines Onkels und des Breslauer Bischofs Johann IV. Roth in Padua“ studierte. In diesem Fall wäre die Widmung des Dialogus der Ausdruck der Dankbarkeit für die Unterstützung seiner Schulung. Da es aber im Text keine privaten Hinweise auf Roth oder auf ihre Verbindung gibt, vermute ich, dass sie sich in der Entstheungszeit des Dialogus in defensionem poetices (das heißt 1492/1493) noch nicht kennengelernt haben. Als ich die Verbindung zwischen Johannes Roth und Augustinus Moravus Olomucensis zu erschließen versuchte, habe ich bemerkt, dass nur ganz wenige Quellen zur Verfügung stehen. Das heißt: Abgesehen von der Widmung an Roth ist kein direkter Kontakt zwischen ihnen zu finden! Es führten zwei Wege zu neuen Erkenntnissen: Einerseits war die Widmung sorgfältiger zu lesen, andererseits waren die Briefwechsel des gemeinsamen Gelehrtenkreises zu untersuchen.

Der erste Weg hat das folgende Ergebnis gebracht: Eine bedeutende Kontaktperson kam zum Vorschein. Am Ende der Widmung erwähnte Augustinus, dass er um 1492 mit einem gewissen Henricus, den er als „,consobrinus tuus" von Roth apostrophierte, in Padua zusammen studierte. ${ }^{14}$

Accessit consilio quod celeberrimo huic patauino gymnasio, ex quo haec nostra quantulacunque sunt prodiere, ea aliquando cum laude praefueris, ut modestiae consilio liberalitateque tuae, quibus id amplissime cumulasti,

Buchwald," in Deutscher Humanismus, Verfasserlexikon 1480-1520, Bd. I. A-K, ed. Franz Josef Worstbrock (Berlin-New York: Walther de Gruyter, 2008), 297-298.

13 Kipf 2009, 27. Vgl. mit dem Mandat, s. Berthold Kronthal and Heinrich Wendt, Politische Correspondenz Breslaus im Zeitalter des Königs Matthias Corvinus (Scriptores rerum Silesiacarum 14), (Breslau, 1894), 193-194.

14 Obwohl es keine Angabe zu Heinrich in den Matrikeln der Universität Padua gibt. Vgl. noch dazu: Gustav Bauch, „Analekten zur Biographie des Bischofs Johann IV. Roth, “ in Darstellungen und Quellen zur schlesischen Geschichte 3 (1907), 97-98. 
perpetuo se debere fateatur, Neque se abs te adhuc obseruari, uel eo etiam argumento colligit, quod Henricum, consobrinum tuum, [Hervorhebung E. R. Sz.] rarae indolis adolescentem, mihique beneuolentia et amore mirifice coniunctum, sinui suo fouendum instituendumque credideris, nil tibi iucundius ratus quam si (quoniam adesse ipse non uales) uel eo saltem exprimerere. $^{15}$

"Consobrinus tuus" bedeutet 'dein Geschwisterkind', mit dem ursprünglich der Neffe oder Vetter mütterlicherseits bezeichnet wurde. Wie schon Bauch und Ekler vermuteten, ist dieser Henricus mit Heinrich Oseven, dem Empfänger von De modo epistolandi identisch. Wegen des großen Altersabstands war Heinrich vermutlich eher der Neffe des Bischofs und Roth unterstützte nicht nur seine Studien, sondern auch seine spätere Laufbahn. Nachdem Heinrich seine Studien abgeschlossen hatte, wurde er Kanoniker im Kreuzstift in Breslau, Dekan von Groß-Glogau und 1501 neben seinem Onkel, der seit 1482 Bischof von Breslau war, Kanoniker des Domkapitels.

Meiner Meinung nach wollte Augustinus den Kontakt mit dem Breslauer Bischof durch dessen Neffen Heinrich und anhand der oben geschilderten Widmung aufnehmen, um die spätere Förderung des Bischofs zu erlangen. Dass Heinrich und Augustinus später auch Freunde blieben, zeigt der De modo epistolandi, den Augustinus 1495 Heinrich widmete. Péter Ekler nahm außerdem an, dass Augustinus mit der Widmung an Heinrich eigentlich auch die Gnade des Bischofs erlangen wollte. ${ }^{16}$ Der Wunsch des Augustinus scheint in Erfüllung gegangen zu sein: 1496 bekam er die Stelle an der königlichen Kanzlei des Wladislaus II. mutmaßlich durch die Vermittlung des Breslauer Bischofs. Als Sekretär zu Ofen lernte er Bohuslav Lobkowitz von Hassenstein, Johannes Sslechta und Konrad Celtis kennen. Diese Freundschaften spielten eine bemerkenstwerte Rolle in seinem späteren Leben und bildeten das Fundament der literarischen Gesellschaft Sodalitas Litteraria Danubiana. ${ }^{17}$

15 Dialogus 13-14.

16 Péter Ekler, „Adatok Augustinus Moravus Olomucensis (1467-1513) életéhez“ [Beiträge zum Leben des Augustinus Moravus Olomucensis (1467-1513)], in Források és hagyományképek, ed. Ágnes Stemler (Bibliotheca Scientiae \& Artis, 5), (Budapest: Országos Széchényi Könyvtár-Gondolat Kiadó, 2014), 101.

17 Zur Geschichte der Sodalitas Litteraria Danubiana s. Tibor Klaniczay, „Celtis und die Sodalitas Litteraria per Germaniam," in Respublica Guelpherbytana, ed. August Buck, Martin Bircher and Paul Raabe (Wolfenbütteler Beiträge zur Renaissance- und Barockforschung. Bd. 6), (Amsterdam: Edition Rodopi, 1987), 79-105; und Moritz Csáky, „Sodalitas litteraria Danubiana: historische Realität oder poetische Fiktion des Conrad Celtis?," in Die österreichische Literatur. Ihr Profil von den Anfängen bis ins 18. Jahrhundert, 1050-1750, ed. Herbert Zeman (Jahrbuch für österreichische Kulturgeschichte 14/15), (Graz, 1986), 739-758. 


\section{Das Verbindungssystem}

Der zweite Erkenntnissweg schien weniger erfolgreich zu sein: Ich habe die Briefwechsel ihrer gemeinsamen Freunden untersucht, um neue Hinweise zu ihrer Verbindung zu finden. Höchstwahrscheinlich hatten sie beide ausgedehnte Korrespondenzpartnerschaften, trotzdem sind ihre Briefwechsel leider nur teilweise erhalten. Diese Tatsache ist vor allem deshalb zu bedauern, da wir aufgrund dieser Briefe nur lückenhafte Kenntnisse über ihre Freundeskreise und ihre gemeinsamen Verbindungen erwerben können. Das untersuchte Korpus waren die Briefwechsel des Bohuslav Lobkowitz von Hassenstein und des Konrad Celtis. Anhand meiner Untersuchungen lässt sich das gemeinsame Netzwerksystem von Roth und Augustinus rekonstruieren. Das wichtigste Bindeglied zwischen Augustinus und Roth ist Heinrich Oseven. Neben Oseven ist Bohuslav Lobkowitz von Hassenstein als Kontaktperson wahrzunehmen, obwohl es nicht nachwiesbar ist, ob Hassenstein mit Roth korrespondierte. Trotzdem wird der Breslauer Bischof in der Korrespondenz des Lobkowitz mehrmals erwähnt. Augustinus schrieb ihm Anfang 1494 und erwähnte, dass er den Dialog an Roth dedizierte:

Et ego scilicet sacratissimo nuper canonicorum tuorum collegio ascriptus preaesulem hunc meum absque piaculo quodam praeteream et, qui reverendissimum Iohannem, Vratislaensem antistitem, dialogo quodam nostro donarim, te, qui pari litterarum splendore coruscas, laborum meorum communione exortem faciam, ut non mihi maiori laudi ducam, si a tot talibusque viris vigiliae meae comprobarentur? ${ }^{18}$

Lobkowitz stand nicht nur mit Augustinus in regelmäßiger Korrespondenz, sondern auch mit Johannes Sslechta und Konrad Celtis. Zwischen Lobkowitz und Sslechta fungierte ein gewisser Henricus als Übermittler, der meiner Meinung nach vielleicht mit dem oben genannten Heinrich Oseven identisch ist. ${ }^{19}$

\section{Zusammenfassung}

Das bearbeitete Material deutet darauf hin, dass zwischen Johannes Roth und Augustinus Moravus Olomucensis keine enge Verbindung nachzuweisen ist.

18 Augustinus an Lobkowicz, A. D. 1494, vgl. Bohuslai Hassensteinii a Lobkowicz Epistulae, Tom. 2., ed. Jan Martínek and Dana Martínková (Leipzig: Teubner, 1980), 40. Von nun an: Lobkowicz, Epistulae.

19 „Reliqua ex Henrico cognosces." - Lobkowicz an Sslechta, 1. April 1500, vgl. Lobkowicz, Epistulae 74. Siehe auch "Quae ad me per Henricum scripsisti, ea huiusmodi sunt, ut tum tibi respondere possim, quum condiciones, quibus in numerum aulicorum adscribendus sum, intellexero." - Lobkowicz an Sslechta, 15. Juli 1500, vgl. Lobkowicz, Epistulae 74. 
Vermutlich von Heinrich Oseven empfohlen, widmete Augustinus sein erstes Werk dem Breslauer Bischof, so dass die Widmung als eine Bitte um spätere Förderung galt. Aus den oben geschilderten Zusammenhängen geht klar hervor, dass Augustinus den Kontakt mit Roth zwar erfolgreich aufgenommen hat, die beiden aber trotzdem keine Freunde wurden und keinen gemeinsamen Freundeskreis besaßen. 


\section{ZOLTÁN CSEHY}

\section{Augustinus noster: Augustinus Olomucensis nella poesia di Bohuslaus Hassensteinius}

L'ambiente letterario e scientifico di Augustinus Moravus Olomucensis fu sempre variegato e ricco d'impulsi: non diversa doveva essere la situazione ai tempi degli studi di Augustinus a Cracovia, a Padova e a Ferrara, nonché a Buda, dove dal 1496 al 1511 egli lavorò nella cancelleria del re Vladislav. Alla cerchia che Tibor Klaniczay chiamava contubernium un tempo appartenevano altresì due poeti all'epoca assai stimati, Girolamo Balbi e Bohuslav Hasištejnský z Lobkovic. " "La piccola isola del patriottismo boemo nel mare cosmopolita dell'umanesimo", come József Fógel chiamò pateticamente il circolo di Buda, nel tono usuale della sua epoca, ${ }^{2}$ eppure Augustinus Moravus non risulta essere stato isolato. Senza dubbio il rapporto fra i suoi membri non si limitava agli incontri diretti, ma assumeva la forma più comune nell'era dell'Umanesimo, vale a dire il carteggio.

Augustinus era uno degli amici intimi di Bohuslav Hasištejnský z Lobkovic, e anche la loro carriera poetica presenta molti parallelismi, benché Bohuslav Hasištejnský z Lobkovic divenne il maggiore poeta dell'Umanesimo boemo, mentre l'attività poetica di Augustinus Moravus Olomucensis cadde in oblìo; solo alcuni dei suoi componimenti compaiono qua e là, dove meno li si aspetterebbe, ad esempio quale proemio del De incognitis vulgo di Galeotto Marzio, quale epilogo del De modo epistolandi (Ad librum), ${ }^{3}$ o nelle Episcoporum Olomucensium series. ${ }^{4}$ Fógel data l'inizio dell'amicizia tra Bohuslav Hasištejnský z Lobkovic e Augustinus Moravus Olomucensis al 1497, e indica come mediatore Jan Šlechta. ${ }^{5}$ Secondo Martínek, 1'Hassensteinius arrivò a Buda il 13 maggio del 1502 e vi restò fino al 11 maggio 1503: l'elaborazione poetica

1 Klaniczay Tibor, "A Sodalitas Litteraria Danubiana," in idem, A magyarországi akadémiai mozgalom elötörténete, (Budapest: Balassi, 1993), 50-77.

2 Fógel József, Hasišteini Lobkovic Bohuslav a magyarországi humanisták között = Dolgozatok Békefi Remig egyetemi tanári működésének emlékére (Budapest: Stephaneum, 1912), 212-221. Citato alla pagina 218.

3 Ekler Péter, “'Epistolaris itaque formula attenuato stilo ducetur potissimum...'. Az ideális stílusnem kérdése Augustinus Moravus Olomucensis De modo epistolandi-jában," in Convivium Pajorin Klára 70. születésnapjára, ed. Enikő Békés, Imre Tegyey (Budapest, Debrecen: Debreceni Egyetem, 2012), 75-81.

4 Augustini Olomucensis Episcoporum Olomucensium series, ed. Franciscus Xaverius Richter (Olomouc: Skarnitzl, 1831), XIV.

5 Fógel József, Hasišteini Lobkovic Bohuslav a magyarországi humanisták között, (v. la nota 2), 212. 
delle esperienze di tale periodo si protrae anche nel periodo dopo il ritorno in Boemia. ${ }^{6}$

Scorrendo il carteggio di Bohuslav Hasištejnský z Lobkovic ed annotando i riferimenti all'attività poetica, ci si rende conto con sorpresa di quanto è scarso il numero dei testi, fra quelli pervenutici, che trattano questa fruttuosa amicizia in forma di poesia, ed essi pure sono tutti componimenti brevi, quasi senza eccezione di carattere epigrammatico. In una lettera scritta il 22 aprile del 1497, Bohuslav Hasištejnský z Lobkovic parla della poesia di Augustinus con parole assai calorose ed entusiaste: "Legi opuscula tua, Augustine suavissime, partim heroo partim elego versu scripta, et ingenio tuo mirum in modum delectatus sum. Nihil enim plebeium, nihil triviale, et quod communi vena editum dici possit, sapis: sed ita tecum, nescio quomodo, certas, ut haud facile discerni queat, utro in scribendi genere sis melior. Assumis interdum tragicam gravitatem, rursus, ubi res expostulat, molliter fluis. Quotiens bellicum canis, militaribus mihi castris interesse videor. Ubi ludis amores, nihil te concinnius, lepidius festiviusque est" ${ }^{\prime}{ }^{7}$

Ciò premesso, va precisato che lo scopo della mia relazione non è comunque la valutazione o la ricostruzione della produzione poetica di Augustinus, ma solo l'esame degli aspetti poetici ed estetici degli epigrammi di Bohuslav Hasištejnský z Lobkovic relativi all'Augustinus. Rivolgo una particolare attenzione anche ai tentativi di canonizzazione rintracciabili in queste poesie, nonché ai rimandi intertestuali.

In base all'edizione critica solo quattro poesie furono indirizzate esplicitamente all' Augustinus, e in altre due egli viene menzionato per nome. ${ }^{8}$

L'epigramma intitolato De doctore Augustino Olomucensi è un esempio del classico epigramma comparativo. La forza poetica del testo scaturisce dall'identità del nome e dalle comparazioni. Nella parte espositiva vengono messi a fuoco i parallelismi, mentre nella parte centrale la gerarchia viene invertita, e la conclusione funziona come giustificazione della tesi centrale:

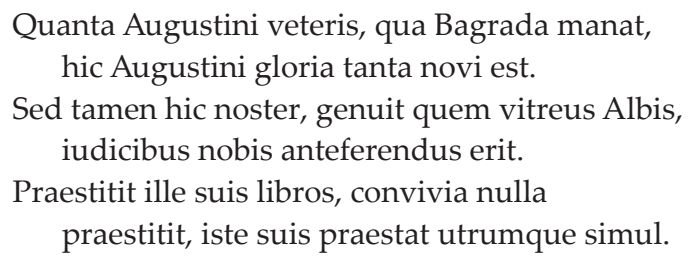

6 Jan Martínek, "Ke kritice a datovaní básníckého díla Bohuslava z Lobkovic," Listy Filologické 103 (1980), 235.

7 Bohuslaus Hassensteinius Baro A Lobkowicz, Epistolae, ed. Augustinus Potuček (Budapest: Egyetemi Nyomda, 1946), 50.

8 Bohuslaus Hassensteinius a Lobkowicz, Opera poetica, ed. Marta Vaculínová (Munich-Leipzig: K. G. Saur, 2006), 303. 
Naturalmente, la tensione si crea non solo grazie al dinamismo crescente, bensì al delicato colpo di scena umoristico. Il campo semantico comune è creato dalla figura di Sant'Agostino come scienziato e dall'identità del suo nome con quello di Augustinus. L'estetica esistenziale dello scienziato viene sopraffatta giocosamente dalla volontà di una vita di società. Il convivio, naturalmente, può essere interpretato in senso metaforico, come corrispettivo del nutrimento dello spirito - la metafora del cibo, peraltro, è usata dallo stesso Sant'Agostino, ad esempio nella sua opera De doctrina christiana: "inter se habent nonnullam similitudinem vescentes atque dicentes, propter fastidia plurimorum etiam ipsa, sine quibus vivi non potest, alimenta condienda sunt". ${ }^{9}$ Sant'Agostino mette in relazione l'atto del parlare e quello del mangiare: né l'uno né l'altro ha sapore o nutrimento senza sale. Altre metafore relative al cibo usate da Sant'Agostino vengono riportate da Ernst Robert Curtius: Dio può figurare come nutrimento interiore (interior cibus), la verità come alimento. ${ }^{10} \mathrm{Il}$ poeta non sfrutta appieno queste potenzialità metaforiche, tuttavia non si può escludere dall'interpretazione della poesia l'immagine del convivio umanistico quale nutrimento dello spirito. Augustinus Moravus si presenta come anima e sostenitore di una comunità di umanisti, e in tale gesto si scopre, forse, non solo il segno di un edonismo intellettuale.

Negli epigrammi vengono menzionati dei fiumi: il Bagrada, nel Nord Africa che rimanda a Sant'Agostino, e il cristallino Elba. In tale gesto possiamo intendere anche l'avventuroso viaggio dell'intelletto dalla periferia al centro, come man mano lo stesso paesaggio viene emblematizzato includendo nel proprio mito il padre fondatore di tale mitologia specifica.

Nel linguaggio dell'epigramma il poeta prese da esempio, come segnalato nell'edizione critica, i vv. 205-206 di Ov. Her. 16:

Nec, puto, collatis forma Menelaus et annis

Iudice te nobis anteferendus erit.

Sed tamen hic noster, genuit quem vitreus Albis, iudicibus nobis anteferendus erit. (Hassensteinius)

Vale la pena riflettere se anche qui si tratta di una protesi linguistico-stilistica e metrica, oppure si può avvertire un dialogo fra i due testi in una dimensione intertestuale, se il brano esaminato ha una forza evocativa. Il poeta non ha fatto altro che prendere in prestito un luogo parallelo adatto. Simili pentametri protetici si riscontrano normalmente in autori umanistici:

9 IV, 11, 26.

10 Ernst Robert Curtius, Evropská literatura a latinský středověk (Praga: Triáda, 1998), 152-153. 
Margara, siquis erit merito tibi dignus amari,

Fabritius cunctis anteferendus erit. ${ }^{11}$

Un brano del Xandra di Landino $(2,6)$ rassomiglia formalmente all'epilogo di Augustinus:

Praestitit ille suis libros, convivia nulla
praestitit, iste suis praestat utrumque simul.

Nec vos materies nec merces carminis unquam

Deseret: hoc virtus praestat utrumque Petri.

In questi casi si tratta senz'altro di un puro parallelismo linguistico, mentre nessun accenno vi è a qualsivoglia dialogo tra i testi.

La struttura comparativa nel componimento no. 12 di Isidoro di Siviglia si rivela nel confronto fra Agostino e Gregorio, ma essa qui ha un ruolo non tanto intensificante o gerarchizzante bensì compensatorio. Il dialogo fra i testi è rilevante dal punto di vista della costruzione:

Quantum Augustino clares tu, Hippone, magistro,

Tantum Roma suo praesule Gregorio.

Il poema no. 6 dello stesso autore mette in risalto la moltitudine dei libri di Sant'Agostino, anzi, ritiene pressoché impossibile leggerli tutti. L'opera agostiniana è, quindi, la manifestazione di una conoscenza enciclopedica:

Mentitur, qui te totum legisse fatetur;

Aut quis cuncta tua lector habere potest?

Namque uoluminibus mille, Augustine, refulges;

Testantur libri quod loquor ipse tui.

Quamuis multorum placeat praesentia libris,

Si Augustinus adest, sufficit ipse tibi.

L'Hassensteinius doveva avere molta familiarità con gli elogi di Sant'Agostino che ci sono pervenuti nelle opere degli umanisti, come ci mostrano alcuni momenti del breve epigramma. La poesia di Enea Silvio Piccolomini intitolata Ad laudem Augustini (Carmina varia, 20) è un ritratto splendidamente ben proporzionato e, al contempo, una preghiera, che traccia il parallelismo tra un ambiente barbarico e l'incanto dell'iniziazione alla sapienza divina segreta:

11 Giovanni Marrasio, 6, 1-2, ad Margaram, ut Fabritium redamet et Grifo Siculo in amore non respondeat. 
Barbarice gentis decus, Augustine, perenne,

Horrida quem nobis Africa terra tulit,

Qui scripturarum profers arcana sacrarum

Eloquiis reserans abdita cuncta tuis,

Doctior ingenuaque omni cultissimus arte

Et studio prestans ingenioque nitens,

Quem nihil obscurum latuit, sed et omnia clarent

Atque humana simul dogmata et alma patent,

Cuius et instruimur doctrinis atque monemur,

Exemplis probitas cuius in orbe micat,

Milia librorum per te, pater alme, leguntur

Edita que promunt quicquid ubique latet.

Sis fautor nobis pius, o sanctissime presul,

Atque deo nostras offer ad alta preces.

Il passo ricalcato su Agostino "Praestitit ille suis libros" è, con molta probabilità, il riassunto degli elogi del tipo di: "Milia librorum per te, pater alme, leguntur / Edita que promunt quicquid ubique latet".

Nel no. 13 del ciclo poetico del Pontano, noto come De laudibus divinis, nell'Hymnus ad Divum Augustinum Carthaginiensem, similmente, si fa menzione delle origini barbariche e della sua cultura ineguagliabile; la conclusione, anche in questo caso, è una preghiera:

Det monstra infelix tellus massyla, det angues,

Et libycas pariat punica terra leas,

Arescant sitiente solo nasamonica tesqua,

Funditet et nullas gleba libystis aquas,

Dum tamen, Augustine, tuos non deneget ortus,

Laeta sit et partu cinyphis ora tuo;

Unde illi invideant et felix Lydia, et arva

Quae rigat auriferis lucidus Hermus aquis,

Invideat latis audax Germania terris

Dives aquis, populis dives et ipsa suis.

Nil etenim, Augustine, tulit tete Africa maius,

Cuius ab ingenio creverit alma fides.

Per te relligio Christi stetit integra, per te

Divinae legis mystica operta patent;

Tu secreta Dei pandis, tu tradita patrum,

Et verum et pietas manat ab ore tuo.

Et pater et patriae princeps, et maxime rector,

Accipias voces, dive benigne, meas.

Sembra che il passo "Et verum et pietas manat ab ore tuo" sia evocato, in senso allegorico, dall'insolita iunctura "qua Bagrada manat". Pare indubbio 
che l'Hassensteinius conoscesse questi testi eruditi e che anch'essi siano coinvolti nel gioco del suo epigramma, composto in chiave comica.

La poesia in forma di comparazione scritta dall'Hassensteinius e intitolata De Augustino Moravo decretorum doctore, basata anch'essa sull'omonimia (n. 103. nell'edizione critica), è ancora più fedele agli schemi dei componimenti agostiniani di Enea Silvio Piccolomini e del Pontano, quando localizza Augustinus Moravus nell'Africa di sant' Agostino:

Hic Augustinus nostrae est splendorque decusque ${ }^{12}$ priscus erat Libycae gloria barbariae.

L'Hassensteinius, tuttavia, va oltre la rappresentazione della semplice duplicità della persona di Agostino, la sapienza sacrale e la gioia di vivere, tentando di assegnare un posto ad Agostino nel mondo poetico del suo tempo. La poesia no. 430 dedicata a Ioannes Sturnus mette in rilievo le virtù di Agostino tramite gli schemi dell'epitaffio di Janus Pannonius, concepito dallo stesso poeta ungherese.

$$
\begin{aligned}
& \text { Qui primus gelidum Musas deduxit ad Albim, } \\
& \text { haec mittit Sturno munera parva suo. } \\
& \text { Vatis erat donum, vatis monumenta tulisti, } \\
& \text { nempe Augustinus quae dedit, ipse capis. }
\end{aligned}
$$

Vale la pena di volgere una maggiore attenzione al ruolo di Janus Pannonius nel processo di autocanonizzazione dell'ambiente umanistico boemo. Nell'epigramma comparativo dell'Hassensteinius intitolato Comparatio Bohemiae et Pannoniae troviamo un confronto fra Ungheria e Boemia, in cui viene sottolineata la superiorità culturale dei boemi (cultior est multo Boemia Pannonia, 4); in questo contesto, per iperbole, Ján Šlechta è collocato sullo stesso livello di Janus Pannonius: Nos dedimus Sschlechta, Ianum dedit illa poetam. (7). Bohuslav Hasištejnský z Lobkovic, in una sua poesia dedicata a Ján Šlechta, fa invece le lodi di Girolamo Balbi al pari di Janus Pannonius, intonando lo stile dell'epitaffio del Pannonius, ed adattandosi alle convenzioni della canonizzazione del culto di Janus, presentandolo come il primo e fondamentale poeta neolatino della Boemia: ...Janus, patrium qui primus ad Histrum, / Duxit laurigeras, ex Helicone, Deas. (De se aegrotante in castris, 117-118). ...debemus Balbo, qui mores, carmina, linguam I Albigenas primus detulit ad populos (Bohuslav Hasištejnsky z Lobkovic, Ad Ioannem Sslechtam, 5-6). Janus fu il primo a portare alle sponde del Danubio le vergini dell'Elicone, mentre Balbi per primo portò al popolo dell'Elba la poesia. Possiamo quindi constatare che la rappresentazione del Balbi sul modello di Janus oltrepassò i confini dell'Ungheria, acquistando un ruolo, nella poesia elo-

12 Una simile soluzione linguistica: "Tecum arma et paces, tecum splendorque decusque" (Marullus, Ep., 2, 11, 3). 
giativa, almeno pan-mitteleuropeo. Lo stesso Balbi si presentava come un secondo Janus Pannonius sperando in una carriera mitteleuropea, mentre in Italia cercava di apparire nelle vesti di Ovidio in esilio. Tale doppia strategia di autorappresentazione si traduceva in un doppio atteggiamento retorico-poetico. L'Hassensteinius applica lo schema di Janus all' Agostino poeta senza nominare Janus Pannonius, elogiandolo come il primo poeta fondatore - come, peraltro, fa con Balbi -, che fece arrivare le muse al gelido Elba, esattamente come Janus le aveva attirate al Danubio. La poesia parte dalle alte sfere di un enigma che in seguito viene sciolto con la menzione di Agostino. Il poeta usa brillantemente la strategia dell'opposizione, trasformando i piccoli doni e le opere letterarie monumentali negli elementi organizzativi dell'epigramma. Nella poesia di Girolamo Balbi intitolata Ad Pomponium Laetum, praeceptorem suum epistola troviamo una simile descrizione del gesto del dono di una poesia, accompagnata da un'identica impostazione del testo:

Et tibi dona feram gelida collecta sub Arcto;

Dicam, Pomponi, munera parva cape.

Nella variante mitteleuropea della poesia neolatina dell'epoca l'opera di Janus Pannonius e la sua fama in Italia doveva costituire una specie di etalon, in cui sia la stessa autorappresentazione da parte del Pannonius, sia l'intenzione canonizzante dei componimenti di altri poeti lo rese automaticamente la figura ispiratrice delle mitologie poetiche personali.

In due degli epigrammi dell'Hassensteinius relativi ad Agostino si fa accenno alla vita amorosa di Augustinus e alla sua attrazione per la poesia erotica $(105,112)$. Non solo egli compose poesia erotiche, ${ }^{13}$ ma portò anche a termine e poi pubblicò le emendationes catulliane e priapee del suo ex professore, Girolamo Avanzi. ${ }^{14}$

Come è segnalato nell'edizione critica, l'epigramma no. 105 - che inizia con la parafrasi di un verso dell'ovidiana Ars amatoria (3, 547: "Vatibus Aoniis faciles estote, puellae:") - fa accenno alle varie avventure di Agostino:

Vati Augustino faciles estote, puellae, quippe nec infirmas deserere ille solet.

Altamente probabile è tuttavia l'influenza anche di testi neolatini. Un passo simile si ritrova nel De Hortis Hesperidum del Pontano (2, 11-12):

Vos quoque adeste simul facilesque estote, puellae Hortorum memores.

13 Klaniczay, "Sodalitas," (v. la nota 1), 66-67.

14 Julia Haig Gaisser, "Catullus," in Catalogus Translationum et Commentariorum, vol. VIII., ed. Virginia Brown, (Washington, DC: The Catholic University of America, 1992), 232. 

9-10):

Inoltre, Girolamo Carbo si rivolge alle muse nello stesso modo (Carm., 1,

$$
\begin{aligned}
& \text { Nunc mihi (si quando) faciles estote roganti, } \\
& \text { Nunc mea pierius irriget ora liquor. }
\end{aligned}
$$

Il collegamento delle muse e degli amanti e la metaforizzazione erotica del processo poetico appartiene alle procedure retoriche a specchio proprie della poesia umanistica. La serietà della parola vates richiama lo stesso punto comico di tensione.

L'epigramma no. 112., sempre di argomento erotico, si conclude sentenziando:

$$
\begin{aligned}
& \text { Prodigia haec nobis quid tandem, Sslechta, minatur? } \\
& \text { Nam Veneris caluit qui face, febre calet. }
\end{aligned}
$$

L'espressione "febre calet" ha origine in Giovenale (Sat., 10, 218), come del resto è ricordato nell'edizione critica dei carmi dell' Hassensteinus, ma per quanto riguarda la forma della prima parte della sentenza fra i archetipi va annoverato il verso 377 dell'Hercules Oetaeus di Seneca:

Vbique caluit, sed leui caluit face.

L'ideale di amore che si delinea in questa poesia è di carattere almeno edonistico; allo stesso tempo il poeta ricorre sia all'immagine di Amore con la fiaccola, sia agli elementi del sistema metaforico amore-malattia.

Agostino compare inoltre nell'epigramma intitolato De libris Georgii Trapezuntii contra Platonem (121). L'Hassensteinus chiede ad Agostino riguardo alla famosa opera del Trapezunzio: nel carme è formulato il pregiudizio stesso nei confronti della scienza dell'autore critico nei confronti di Platone, pregiudizio espresso con la dura apostrofe "novi dementia monstri". Quest'espressione ha origine probabilmente in Claudiano (In Rufinum, 2, 99: "Languescent auidique cadet dementia monstri"), e tale platonismo deciso e imperterrito permea l'intera poesia.

In conlusione, si può affermare che negli epigrammi dell'Hassensteinius si delinea un doppio carattere di Agostino: da una parte il poeta depositario della tradizione umanistica di cui Janus Pannonius, che sta assumendo lo status di classico, rappresenta l'emblema; dall'altra una figura viva, in carne e ossa, del circolo umanistico, un uomo incline allo scherzo, un uomo di compagnia non scevro dalle miserie umane. La tecnica poetica dell'Hassensteinius si serve dell'imitazione sia dei modelli antichi che di quelli contemporanei o neolatini: tale uso dei modelli, tuttavia, almeno per quanto si ricava dalla testimonianza dei componimenti qui esaminati, raramente ricorre alla funzione evocatrice dell'intertestualità, ma cerca piuttosto di estrarre gli elementi linguistici dal contesto antico, in cui essi ricorrono come familiari e usuali. 


\title{
FARKAS GÁBOR KISS
}

\section{Augustinus Moravus and the Transmission of Ancient Wisdom in the Context of Poetry:}

\author{
In defensionem poetices
}

When Augustinus Moravus published his dialogue about the Defense of poetry in Venice in the spring of 1493, the subject was hardly a novelty. A number of humanists-including such luminaries as Petrarch or Boccaccio-had tried their pens at the subject and produced treatises which repositioned poetry and rhetoric in the social and scholarly value system of the 14th and 15th centuries. Most of these efforts had an antagonistic attitude to medicine and law, two major disciplines taught at universities in the later Middle Ages: Boccaccio placed poetry in the context of a virtual defense against the attack of law and jurisprudence, ${ }^{1}$ while Petrarch positioned his praise of rhetoric within epistemological invectives against medicine and the scholastic use of language (1352-1353). ${ }^{2}$ Whereas Boccaccio and Petrarch were writing outside the university environment, the debate itself clearly affected the question of ranking between the arts courses, medicine, and law, and it was within the university context that Augustinus Moravus envisaged his own defense of poetry. His dialogue, written and situated in Padua, the most important university town in Northern Italy, depicts a vivid discussion between Augustinus, the author's alter ego, Laelius, a defender of medicine, and Bassareus, a comic doctor, on the merits of poetry as compared to other arts and sciences, especially to medicine; Laelius even tries to persuade Augustinus to study medicine instead of poetry.

1 See Vittorio Zaccaria, “La difesa della poesia nelle 'Genealogie' del Boccaccio," Lettere italiane 38 (1986), pp. 281-311. For the text, see Giovanni Boccaccio, Genealogie deorum gentilium - De montibus, silvis, fontibus, lacubus, fluminibus, stagnis seu paludibus, de diversis nominibus maris, ed. Vittorio Zaccaria, 2 vols., (Milan: Mondadori, 1998-1999). For an English translation, see Boccaccio, Genealogy of the Pagan Gods, ed. and trans. Jon Solomon (Cambridge MA and London: Harvard University Press, 2011). This study was supported by the projects OTKA PD-104316 and the MTA Lendület program.

2 For the text, see Petrarch, Invective contra medicum, ed. Francesco Bausi (Florence: Le Lettere, 2005). For a convenient summary of the debate, see Stefano Cracolici, "The Art of Invective," in Petrarch: A Critical Guide to the Complete Works, eds. Victoria Kirkham, Armando Maggi (Chicago: The University of Chicago Press, 2009), 255-262, 440-449 and Nancy Struever, "Petrarch's 'Invective contra medicum': An Early Confrontation of Rhetoric and Medicine," Modern Language Notes 108 (1993): 659-679. 
Although many of the dialogue's arguments are unoriginal and can be retraced to ancient sources and earlier defenses of poetry, ${ }^{3}$ Augustinus significantly re-elaborated the subject in several aspects. First, the target audience of his dialogue was completely novel, as he addressed his dialogue to a Central European readership, and his text had a considerable reception in the circle of German humanists. Second, as I will try to show in this paper, unlike Petrarch, whose assault at medical studies relied on philosophical and linguistic reasoning, Augustinus based his attack against medicine on the importance of astrological influences and cosmic sympathies, a field, which he considered to be unknown to most "empirical" doctors of his day. Third, his ideas on the defense of poetry were framed within the context of the translatio studii, the transmission of learning, as he thought that his age was an elected one, when scholarship might flourish again thanks to the printing press.

Augustinus propagated these ideas in Central Europe by dedicating the text in Padua to two distant patrons, who were important for the advancement of his earlier career: to Johannes Roth, bishop of Wrocław and to his uncle Andreas Ctibor, canon of Olomouc. ${ }^{4}$ Johannes Roth, who might have supported him even before his study tour to Italy, belonged to the oldest generation of German humanists. Augustinus's work might have appealed to him particularly, as he was the author of a text with similar content in his younger days, a letter exchange with Gregor Heimburg (1454), in which he emphasized the merits of rhetoric as an art in his own right, and brought several arguments against the study of law. ${ }^{5}$ Roth claimed that law has only regional validity, and it needs no creativity ("perspicuitas", "ingenii

3 For a discussion of the sources, see Karel Svoboda, "Augustina Olomouckého 'Dialog na obranu básnictví"," Listy filologické / Folia philologica 69 (1942), 20-33 and Karel Svoboda, "Il dialogo 'In difesa della poesia' di Agostino da Olomouc," Lettere italiane 8 (1956), 34-49.

4 See Augustinus Moravus, Dialogus in defensionem poetices, (Venice: [Paulus Fridenperger], 24 March 1493), 2r-3r (to Johannes Roth, Padua, Nov. 13, 1492), 17v-18v (to Andreas Ctibor, Padua, Nov. 19, 1492). (GW 3057) For the support of Ctibor and Roth to Augustinus, see Ralf Georg Czapla, "Augustinus Moravus," in: Verfasserlexikon: Deutscher Humanismus, 1480-1520, ed. Franz Josef Worstbrock (Berlin: de Gruyter, 2006), vol. 1., cc. 61-62. A critical edition was published by Karel Svoboda: Augustini Olomucensis Dialogus in defensionem poetices, ed. Karel Svoboda (Prague: Česka akademie věd a umění, 1948). As it has a number of mistakes in transcription (see Bohumil Ryba, "Augustini Olomucensis...," Listy filologické 73 (1949), 4449), I will refer to the incunable print.

5 For a partial edition, see Paul Joachimsohn, Gregor Heimburg (Bamberg: Büchner, 1891), 310316. On Roth, see Franz Josef Worstbrock, "Roth, Johannes," in Verfasserlexikon 8 (1993), 269275; Rainald Becker, "Der Breslauer Bischof Johannes Roth (1426-1506) als 'instaurator veterum' und 'benefactor ecclesiae suae'. Eine Variation zum Thema des Humanistenbischofs," Römische Quartalschrift für christliche Altertumskunde und Kirchengeschichte 96 (2001), 100-123; with important additions by Agostino Sottili, "The Humanist Education of Johannes Roth, the Prince-Bishop of Breslau," in id., Humanismus und Universitätsbesuch: Die Wirkung italienischer Universitäten auf die Studia Humanitatis nördlich der Alpen, (Leiden: Brill, 2006), 396-412, esp. 407-408. 
acumen"), as it consists in just memorizing rules. Furthermore, its main subject of study, the Digest, is as confused as a labyrinth, whereas those fields of scholarship are more praiseworthy which are clearer and cover larger territories of knowledge. ${ }^{6}$ Indeed, their common interest in the revival of oratory and poetry might have prompted Augustinus to dedicate his work to Bishop Roth.

Augustinus tried to reach beyond the direct circle of his dedicatees. He envisaged a broad and highly educated readership for his work at home, which would include not only his uncle and the cultivated bishop of Wrocław, but also Bohuslaus Hassenstein-Lobkowitz, Ulrich von Rosenberg (Ulrichus de Rosis, Oldřich III. z Rožmberka), and Ladislaus (Ladislav) of Boskovice, the intellectual and social elite of Bohemia and Moravia in the late 15th century. ${ }^{7}$ Not only Bohuslaus Hassenstein-Lobkowitz, the most renowned humanist poet of Bohemia, but also Ulrich von Rosenberg and Ladislaus of Boskovice were obvious choices for readership at home. Rosenberg studied in Bologna with Filippo Beroaldo the Elder in 1487-1489, where the Italian master dedicated his Annotationes centum (1488, GW 4113) to him, and they remained in epistolary contact at least until $1494 . .^{8}$ Similarly, Ladislaus of Boskovice belonged to the social and cultural elite: he was attached to the court of King Matthias and a surviving manuscript shows his interest in classical literature. ${ }^{9}$ He commissioned probably the earliest Renaissance

6 "Illa autem doctrina est praestabilior, quae res praeclariores et plures comprehendit, quam ea, quae solum litigandi formas complectitur et facilis est." (Joachimsohn, o.c., 312.)

7 "Satis nobis fuerit, si eas [lucubrationes] Reverendissimus Vratislaviensis Antistes, cuius eas nomine emisimus, non reprobet. Si Udalricus de Rosis, si Bohuslaus de Hassenstein, si Ladislaus de Bozkovis inter proceres Regni Boemiae tum Latinarum, tum Graecarum litterarum peritissimi, si Joannes denique meus Oppaviensis, inter primores civitatis Olomucensis senator optimus...". Ibid. 18r-v. Ulrich von Rosenberg (Oldřich z Rožmberka, 1471-1513), had a significant library.

8 See Bohumil Ryba, "Filip Beroaldus a čeští humanisté [Filippo Beroaldo and the Czech humanists]," in Zpráva o činnosti městského musea v Č. Budějovicích za léta 1932 a 1933, (Ceské Budejovice: Karel Fiala, 1934), 6-7, 10-11, 19-10, esp. note 63. Beroaldo tried to seduce Ulrich back to Italy by listing the major attractions of Bologna, scholarship, hunting and brothels ("Urbs nostra si unquam scortis abundavit, nunc maxime habundat, si unquam floruit, nunc maxime floret. Omnia sunt plena voluptatum multiplicium. Nullus est in homine sensus, qui [lege: cui] non sit apud nos titillacio et blandimentum. [...] Potes venari, scortari, potes etiam studere." Ibid., 20).

9 Alois Vojtěch Šembera, Páni z Boskovic a potomní držitelé hradu boskovického [The Lords of Boskovice, and the later lords of the castle of Boskovice], (Vienna: private edition, 1870) 40-42; Antonín Kalous, "Boskovice urai Mátyás király diplomáciai és politikai szolgálatában," Századok 141 (2007), 375-389. (esp. 387-388). His ms. is Vienna, Österreichische Nationalbibliothek, cod. 3165, a copy of Ovid's Heroides, a typical reading at the arts courses at universities. Cf. Stefan Endlicher, Catalogus codicum philologicorum Latinorum: Bibliothecae palatinae Vindobonensis (Vienna: Beck, 1836), 76. Ladislaus of Boskovice was registered at the University of Vienna in 1471. Kalous, o.c., 387. 
carved stone portraits in Bohemia, representing himself and his wife in the castle of Moravska Třebova, exactly in the years 1492-95. ${ }^{10}$

Augustinus Moravus was conscious of the greatness of the age in which he was living, and the ideas exposed in his contemporary dedicatory letters give us a better understanding of why he attributed such importance to the defense of poetry. As he says in a 1492 letter written to Johannes Lucilius Santritter, the Venetian printer originating from Germany, ${ }^{11}$ he was tremendously excited about the flourishing of humanities:

When I wonder about the general conditions of our age, and especially when I think about it more thoroughly from the point of view of the ancients [ex priscorum illorum imagine] and meditate upon it, I often happen to boast [gloriari] more than it is fair that by chance I was born into an age, when after the almost complete extinction of the fruits of the best disciplines, their study has revived so much that those fields which have decayed by the negligence of the earlier times are now reanimated, and with a kind of resurrected spirit [redivivo quodam spiritu] are alive again and bearing new fruits. $^{12}$

'Gloriari', the word, which Augustinus Moravus picks to describe his feelings here, is well-chosen: his age does not only surpass the recent dark centuries, but through such inventions as printing, this new era also exceeds the wisdom of Antiquity. The "new fruits", which are brought forward by his age, are to be understood not only as imitations of the ancient models, the "fruits of the disciplines", but also as daring, emulative efforts, which may fill contemporary minds with a sense of pride.

To Augustinus, this revival and flourishing of sciences and human studies was closely connected to the transmission of knowledge. As he says in the

10 Jan Chlíbec, "Medallions with the portraits of Ladislav z Boskovic and his wife Magdaléna z Dubé a Lipého," in Matthias Corvinus, the King. Tradition and renewal in the Hungarian royal court 1458-1490, ed. Péter Farbaky, András Végh (Budapest: Budapest History Museum, 2008), 277-278.

11 Santritter arrived to Venice from Heilbronn, and he was hosted in the home of Franciscus Niger, where he set up his first printing press, as he confesses in his first publication, the Grammatica of Niger (Venice, 1480). Cf. also the lines "Santritter Helbronna genitus de gente Ioannes, // Lucilius prompsit grammata docta Nigri" (ibid., f. dd6r). On the possible influence of Niger on Augustinus Moravus, see later.

12 Exhortatoria in impressione tabularum Astronomicarum Alfonsi Regis. Augustinus Moravus Olomucensis Johanni Lucilio Santritter Heilbronnensi: "Quum temporum nostrorum conditionem mecum ipse reputo Johannes Lucili, amice suavissime, eamque ex priscorum illorum imagine diligentius expendo, atque pertracto, gloriari sepe non mediocriter soleo, id me potissimum aetatis incidisse, in quo post defectos paene optimarum disciplinarum fructus, is demum studiorum ardor succreverit, ut quae longa vetustatis negligentia deperierant, iam redeant iterum, ac redivivo quodam spiritu in meliorem propemodum frugem excitentur atque repullulent." Tabule astronomice Alphonsi Regis, ed. Augustinus Moravus (Venice, Johannes Hamann, 1492), A2r. 
dedication written to the Emendationes in Catullum of Hieronymus Avantius in 1495, science was thriving in the antiquity (antiquitas), when libraries were founded and texts were within easy reach to readers. Libraries - treated as a kind of spiritual arsenal - were the preconditions of the flourishing of sciences: "so many highly cultured men, so many famous minds were flourishing at the same time, as soon as these libraries-like some arsenals - were publicly available."13 Thus, the availability of books and the ease of access were prerequisites for the continuous transmission of knowledge and the circulation of ideas. Augustinus claimed that in this sense the literary productions of his own age grew up to the ancient models. The efforts that characterized ancient times in preserving knowledge were taken up again, and books - rich in ideas - could be easily found again: "I cannot but greet in our age that in the moment when the shining light of literature was almost extinct, it returned to those old times, so that-divesting itself of barbary - it might aspire again to that ancient honor, and it invests so much effort into collecting the books of the best authors that soon what we call a lifetime might be too short to read them all."14 The glory of his own days is due to the widespread reading of Pliny, Statius, Pomponius Mela, Properce, and Juvenal-and with the aid of the recommended emendations of Hieronymus Avantius, now also the works of Catull would be read with more use and pleasure. The process that Augustinus describes here, is closely connected to the idea of the translatio studii, the transmission of knowledge from age to age, from language to language and from empire to empire. For him, passing on the knowledge contained in ancient sources is the key to the revival of sciences, and the more texts can be accessed, the more an age will be civilized.

At the same time, the inaccessibility of texts curtails the possibility of a revival, and the interruption in the transmission of knowledge creates an irrecoverable loss. Augustinus implied this view when he bemoaned the loss of ancient writings in the dedication of the Canones of Giovanni Bianchini. As he claimed, "if nobody else, then even Joannes Blanchinus alone gives enough proof of how much benefit there is in the invention of printing with

13 Hieronymus Avantius, Emendationes in Catullum (Venice: Joannes Tacuinus de Tridino, 1495), a1v: "tot viros eruditissimos, tot praeclarissima ingenia uno semel tempore effloruisse, ubi ea excolendi ingenii quasi armamentaria quaedam publicitus exponerentur". Dated to March 5, 1494. Edited in Julia Haig Gaisser, "Catullus," in Catalogus Translationum et Commentariorum, vol. 7., ed. Virginia Brown (Washington, DC: Catholic University of America Press, 1992), 234. About this letter, see also Ludovica De Nava, "L'epistola di Girolamo Avanzi ad Agostino Moravo di Olomuc," Lettere italiane 45 (1993), 402-426.

14 "in quo aevo nostro non gratulari et quidem vehementissime non possum, quod extincto iam prope bonarum litterarum splendore in ea rursum tempora redierit, ut exuta barbarie in pristinum illud decus denuo aspiret taleque congerendis optimorum auctorum libris studium adhibeat, ut id brevi cum his quae diximus tempora vitae confligere possit." in Tabularum Ioannis Blanchini Canones, ed. Augustinus Moravus (Venice: Simon Bevilaqua), 1495, a2r. (GW 4410) The dedication is dated to Padua, Jan. 1, 1495. 
characters"15 - while editing for the first time the astrological tables of this 15 th century astrologer. "Had the invention of printing occasionally happened in those ancient times, we would not have lost the milky eloquence of Livy, the miraculous but still gracious brevity of Sallust, nor Curtius, or Trogus, nor Tacitus, Plautus-and among our astrologers Theogenes, Anthony Musa, Albucius, Rubrius, ${ }^{16}$ and some six hundred other authors. The committed love-heat of Gallus would still survive, and Catull would not only deplore his Lesbia (if those in Hell can feel any pain) - which we all see now either truncated or missing enough even to their authors." 17 Although with a humorous tone-treating the amorous heat of Catull's text as if the ancient poet himself could feel it in the Underworld at the time of reading-Augustinus attributes to transmission the only possibility of saving knowledge from obliteration. As he continues, if the Egyptians had known printing, they would have immortalized and honored the inventor as a god, and he quotes an epigram by Hieronymus Bononius praising the divine discoverer of this art, $^{18}$ in order to point out that books which only kings could afford earlier, can now be found even on the shelves of the poor. Almost anticipating the Eisensteinian narrative of the "printing revolution", transmitting knowledge through easily accessible texts for Augustinus means the sine qua non of a fervent cultural life.

If the affordability of books nourishes culture, their loss entails the decay of civilization. In a few lines of the dedication to the Tabula Alfonsina (1492), which could be regarded even as a literary program, he clearly defines the areas where the loss of knowledge was hitting the hardest in the general decay of sciences: philosophy, oratory, poetics, and mathematics (the latter of which signifies astronomy and astrology in medieval terminology). "All remains of philosophy, oratory, poetics and mathematics were demolished, because the vile barbary has abolished so much that we can still hardly breathe in our age

15 The last three names are taken from Pliny the Elder (Nat. Hist. 29, 5), where they appear as famous doctors of the Augustan age.

16 "Quod si eruditis illis priscorum temporibus obtigisset, non Livii lacteam facundiam, non Sallustii miram cum venustate brevitatem, non Curtium, non Trogum, Tacitum, Plautum, ex nostris quoque astrologis Theogenem, Anthonium Musam, Albucium, Rubrium aliosque sexcentos desideraremus. Viverent adhuc commissi calores Galli, non tantum Lesbiam suam (si quis apud inferos est sensus) indoleret Catullus, quae tamen modo vel manca conspicimus omnia, vel suis et ipsa satis intercepta." Ibid., a2r.

17 "Quantum reipublicae litteariae profuerit recens imprimendorum characterum inventum, Andrea Stibori, amice beneficentissime, etiam si aliorum testimonia desint, unicus nobis Ioannes Blanchinus testimonio evidentissimo existit." in Tabularum Joannis Blanchini canones, ed. Augustinus Moravus (Venice: Simon Bevilacqua), 1495, A2r.

18 Inc. "Tingere dispositis chartas quicunque metallis // cepit...". The epigram appeared first in the De orthographia dictionum of Johannes Tortellius (Treviso: Hermannus Liechtenstein, 1477; GW M47213) and it was later reprinted in other incunables. 
from that deluge, which was by far the worst ever."19 The ideological stance against the medieval past that Augustinus exhibits here was not only his own. In fact, his exhortation follows the suit of the ideas exposed by Marcantonio Sabellico, a prominent professor of the public school of San Marco in Venice, in his dialogue De reparatione linguae Latinae (1490, published in 1494), where the interlocutor Iuliarius explains the same subject with very similar words: ${ }^{20}$

Non Philosophia, non Oratoria, non Poetica, non Mathematica usquam supererat, quoniam feda barbaries ita summerserit omnia, ut a clade illa longe calamitosissima egre nobis ad id usque aevi respirare sit datum. (Augustinus Moravus, ibid.)

Quae, et si non sunt talia, ut iacturam illam, quam nostrae litterae gothica tempestate fecere, omnino resarciant, levant tamen inopiam et egestatem, quam dira illa calamitas latino nomini attulit. Quod malum ita violenter omnia invaserat, ut a clade illa longe vetustissima aegre ad hos annos respirare sit datum. Aliquid igitur effecerunt nostrorum temporum viri, per quos si non rem ipsam, umbram tamen et verum Latinitatis adhuc nomen retinemus, si quidem horum ductu et auspiciis Romanus sermo omnem exuit squalorem, omnem barbariem, quibus sordibus diu fuerat immersus. (Marcantonio Sabellico, De reparatione linguae Latinae)

These citations taken from Sabellico let us position Augustinus within the Venetian-Paduan humanistic intellectual trends of the 1490s. Sabellico's dialogue written on the Reparation of the Latin language might have inspired Augustinus on two different levels: first, as a dialogue situated within a contemporary scenery, it could be used as a generic model for his own In defensionem poetices. Second, the main agenda of Sabellico's text, the revival of

19 "Non Philosophia, non Oratoria, non Poetica, non Mathematica usquam supererat, quoniam feda barbaries ita summerserit omnia, ut a clade illa longe calamitosissima egre nobis ad id usque aevi respirare sit datum." Augustinus Moravus, "Exhortatoria in impressionem tabularum Astronomicarum Alfonsi Regis," in King Alphonse, Tabulae astronomicae, ed. Johannes Lucilius Santritter (Venice: Johannes Hamman, 1492), f. a2r.

20 Marcantonio Sabellico, De reparatione linguae Latinae, ed. Guglielmo Bottari (Messina: Centro interdipartimentale di studi umanistici, 1999), 86-87. See also Patrick Baker, "A Labyrinth of Praise and Blame: On the Form and Structure of Marcantonio Sabellico's 'De latinae linguae reparatione'," in Historiographie des Humanismus. Literarische Verfahren, soziale Praxis, geschichtliche Räume, ed. Johannes Helmrath, Albert Schirrmeister, Stefan Schlelein (Berlin: de Gruyter, 2013), 209-240. At the same time, this citation proves that Augustinus had access to Sabellico's text already before its publication around 1494, as his exhortatory letter is dated to June 16, 1492 (XVI. Kal. Julii). Interestingly, Augustinus's letter was in turn plagiarized in a letter written by Hunoldus, a German Carthusian of Roermond to Johannes Murmellius in 1500 (see Karl Krafft, Wilhelm Crecelius, Beiträge zur Geschichte des Humanismus am Niederrhein und in Westfalen, 2. Teil, Elberfeld, 1875, 32, the first ten lines of his letter are taken verbatim from Augustinus). 
ancient literary culture through interpreting and commenting Greek and Latin texts, can be paralleled to Augustinus's agenda of reinstating-and if possible-surpassing ancient scholarship through the correct understanding of classical texts, and through such revolutionary discoveries, as the printing press.

Philosophy, oratory, poetics, and mathematics (i.e. astrology), the four subjects mentioned in the exhortatory letter of the Tabulae Alfonsinae, united those topics as well that are covered in the In defensionem poetices. The setting of the dialogue explicitly follows a philosophical pattern, and the Platonic dialogues of Gorgias, Phaedrus and Timaeus are commemorated by name. No doubt, Augustinus read the dialogues of Plato in the translation of Ficino, first published in 1484, and used them both as a generic and a thematic model. On the other hand, Augustinus stresses the value of humor as well: the dialogue should indulge in the license of "adages, witty sayings, jokes, just as with some more delightful rhetoric flowers." ${ }^{21}$ In this spirit, the dialogue starts off with a joke: as Laelius finds Augustinus, he remarks that his friend has almost evicted the Helicon, because the Muses are always in his company. The alter ego of Augustinus in the dialogue is not completely happy with this ludicrous approach to poetry, as he immediately challenges Laelius for a debate, so that he could defend the value of poetry. Therefore, they look for a real Platonic grove near the Brenta River with a plane tree, explicitly imitating the beginning of the Phaedrus. A third, farcical figure, Bassareus joins them on the road there already inebriated not by poetry, but by wine. The choice of the church of Mary Magdalene as the background to the debate might be more than haphazard: as Laelius wanted to liberate his friend from poetry, whom he considered as a morally corrupt citharist (Psaltria), ${ }^{22}$ and Mary Magdalene, the patron saint of the church might function as a symbol of conversion and finding moral values even in the lascivious writings of the ancients. ${ }^{23}$ Instead of poetry, Augustinus is advised to study medicine, famously invented also by Apollo, the god of poetry and Aesculapius. Augustinus, incensed by his friend's proposal, starts a twofold defense of poetry: first he annihilates the value of medicine, especially that of traditional, "non-astrologic" medicine, and reveals the truth hidden under the superficial meaning of poetry.

What Augustinus, the author makes his literary alter ego say against medicine, is in many aspects already a literary tradition in his time. He turns

21 "adagiis dicteriis et iocis non secus ac floribus quibusdam amenioribus lasciuiret". Augustinus Moravus, Dialogus, 2r.

22 "Enitar enim Psaltrias has animo tuo si non excutere omnino, at magis magisque indies exosas efficere." Augustinus Moravus, Dialogus, 4v.

23 Augustinus Moravus, Dialogus, 3v. At the same time, a church of Mary Magdalene (used by Benedictine nuns) existed really south of the city centre in Padua until 1509, when it was demolished by the troops of Emperor Maximilian I. See Svoboda, Il dialogo..., 39-40 and Padova: Basiliche e chiese, ed. Claudio Bellinati, Lionello Puppi (Vicenza: Neri Pozza, 1975), vol. 1., 36. 
to anti-medical commonplaces of humanism, when he cites Seneca that the doctors are experimenting at our expense, or he quotes the famous epitaph that the sick person perished because of the great number of doctors ("turba se medicorum interiisse" - originally attributed to Hadrian, the emperor: "turba medicorum perii"), or he reproaches the doctors that they practise the only profession where it is legally allowed to kill. ${ }^{24}$ In fact, Augustinus must have compiled these passages either from a letter of Petrarch's Familiares (V, 19) addressed to Pope Clement VI, where all these arguments occur, or from their enlarged form in the Invectivae contra medicos. Nevertheless, he adds an important new point: a common shortcoming among the doctors of the present is that they are not familiar enough with astrology, although many ancient doctors, including Apollodorus, Albumasar and Galenus suggested that they should be. According to Augustinus, medicine is nothing but divination, and consequently, doctors must study astrology. As he says, "the task of the doctor is to tell what sickness the patient has had, has and will have, and this is already a kind of divination." ${ }^{25}$ Although the connection between medicine and astrology is already present in Macrobius's Saturnalia, this idea takes on a much greater significance when Augustinus actually identifies the two disciplines ("quod est divinationis proprie"). ${ }^{26} \mathrm{He}$ continues to add further arguments in favor of astrological medicine by quoting Celsus about the teaching of critical days. At the same time, he repeatedly criticizes the "empirici medici", the empirical doctors who exercise practical medicine, healing with herbs and potions.

At this point, the dialogue is divided by an interlude, where Bassareus plays the clown, and Augustinus inserts a humorous debate between this drunken friend, who just arrived from Bologna, and the two serious students. This short interplay comfortably divides the dialogue into two major sections, the one dealing with the futility of medicine, and the other handling the wisdom of poetry. It is here that Augustinus exposes his main agenda, the divinatory relevance of poetry: "Should we return to our subject and try our hands at poetry, which you ridicule so much? Because my main intention is that you should come to terms with my Muses, and you should consider those people who are inspired by this divine gift (munus) not less than some kind of

24 Augustinus Moravus, Dialogus, 6v. See in general Svoboda, Il dialogo....

25 "Nam medicus vel commoda vel incommoda in corpore praenoscit, sicut ait Hippocrates. Oportet medicum dicere de aegroto: [Greek print missing], id est quae sint, quae fuerint, quaeque mox futura sequentur. Quod divinationis est proprie. Et alibi: qui vero - inquit - ea quae de re altissima tractavimus rata tenent, norint astrologiam medicinae non minimam esse partem." Augustinus Moravus, Dialogus, 5v. The passage is derived from Macrobius, Sat. 1, 20, 5. Augustinus considered this idea of such crucial importance that he even wanted to print a Greek quotation from Hippocrates to prove his point - but the printer unfortunately could not fulfill the task.

26 Macrobius says only that divination (and not astrology!) and medicine are related, but not identical: "consociatae sunt disciplinae." 
oracles." 27 Instigated by the gods, the poets are nothing but tools in the hands of the immortals: "we offer ourselves to the immortal gods in no other ways than as some tools." 28 In fact, oracle-oraculum seems to be the connecting notion between the art of medicine and the art of poetry. Just as medicine was - or at least should be-according to Hippocratic standards an act of divination, poetry is the revelation of an oracle, and the connecting discipline between the two is astrology. The divine inspiration of the poet, which is perhaps the most common and widespread apologetic argument in favor of poetry in the Renaissance from Boccaccio onwards to Conrad Celtis and Joachim Vadian, becomes a tool of reconciliation here. Divine inspiration and medical divination can reconcile, as it will be represented at the end of the work by the common chanting of the two friends. ${ }^{29}$ Furthermore, astrology provides a link between the two, as the knowledge which may be gathered from the poetic integuments of the ancients relates to the ancient gods - who are planets and stars at the same time.

In the following, Augustinus offers a definition of poetry, which clearly indicates the cultural context in which it was proposed: "poetry is a metric structure of fictitious and true narration, composed with a fitting rhythm or meter, for the sake of utility and pleasure." 30 This statement follows verbatim the definition of poetry given by Diomedes grammaticus, who devoted the third book of his Ars grammatica to the poetic genres and the study of metric. ${ }^{31}$ Diomedes seems to have been popular as a source of literary scholarship in the Veneto region, as Franciscus Niger, a Venetian-Padovan intellectual in the 1480 s and 90 s used the same source for defining the poetic genres in his Grammatica, published in 1480 in Venice. ${ }^{32}$ It is important to note that the same definition is given for poetry by Joachim Vadianus in his De poetica et carminis ratione a few years later (1517), which shows the lasting influence of such

27 "Quin ergo ad institutum potius nostrum revertimur et vel irrisam abs te tantopere poeticen iam tandem etiam adorimur? Volo siquidem ante omnia cum Musis meis in gratiam redeas, atque id genus hominum qui praeclaro hoc munere afflantur non secus ac oracula quaedam suspicias." Augustinus Moravus, Dialogus, 6v.

28 "Quid enim mirabilius [...] ita divino quodam furore corripi, ut dum calore isto inflammanti vires proprias egredimur, nil aliud quam organa quaedam nos diis immortalibus praestemus?"

29 Cf. Augustinus Moravus, Dialogus, 14r. "Salvete o nimium celebres Aganappidos umbrae..."

30 "Poetica est ficte vereque narrationis congruenti Rithmo vel pede composita metrica structura ad utilitatem voluptatemque composita." Augustinus Moravus, Dialogus, 8r.

31 Grammatici Latini, ed. Heinrich Keil, (Leipzig: Teubner, 1857), vol. 1., 473.

32 See by this author, "Franciscus Pescennius Niger Báthory Miklós váci püspök udvarában," Magyar Könyvszemle 127 (2013), 273, note 40. As mentioned above, Johannes Lucilius Santritter, the printer of Augustinus, and the addressee of one of his letters, set up his printing press first in the house of Franciscus Niger and he immortalized their friendship in a poem published in Niger's Grammatica (cf. his poem "omnibus studiosis adolescentibus," Franciscus Niger, Grammatica (Venice: Santritter, 1480), f. dd5r-dd6r; GW M27086). 
technical treatises on poetry in Central Europe. ${ }^{33}$ The popularity of Diomedes's definition of poetry in the Viennese, and in the wider East Central European setting demonstrates the continuity and perhaps even the influence of the ideas exposed by Augustinus.

The poets' divine inspiration logically leads to the idea that their works contain hidden allegorical truth (integumenta) under the literal surface. First, Augustinus expounds the differentiation of Macrobius between the voluptuous tales (as the comedies of Menander, or the novels of Apuleius and Petronius), and virtous tales (as those of Aesopus, or the "narrationes fabulosae", including the poems of Hesiod, Orpheus and the Pythagoreans). ${ }^{34}$ Then, just as many other contemporary critics do, he goes into detail and describes the allegoric truth behind many famous and often cited mythological stories, mostly based on the Mythologies of Fulgence and the Saturnalia of Macrobius. The popularity of such allegorical interpretations is demonstrated by the famous manuscript called Apologia poetarum, compiled by Pangratz Bernhaupt (called Schwenter) and finished in 1505. ${ }^{35}$ In this exquisite codex, all the illustrations designed for the Dialogus in defensionem poetices of Augustinus concern these allegorical scenes from the second part of the dialogue, except for the title page, where the author is depicted, following the typical pattern of early prints (fig. 1.). While all ten illustrations to the text itself deal with the allegorical interpretations of Gods, paradoxically, the pictures offer an almost verbatim pictorial transcription of the literary text in spite of the allegoric content. To quote just a few examples: Saturn (interpreted as Kronos/time) was the son of Caelum (sky), which means that at the time of Chaos there was no time, as we measure time from the skies. Similarly, Jupiter chasing away Saturn is a lesson for us all that new times change earlier times,

33 Vadian, De poetica et carminis ratione, cap. 1. (Vienna: Singrenius, 1517), f. b1v and Joachim Vadianus, De poetica, Bd. 1., Kritische Ausgabe, ed. Peter Schäffer (Munich: Fink, 1973), 13. See also Jörg Robert, Konrad Celtis und das Projekt der deutschen Dichtung (Tübingen, Niemeyer, 2003), 68. Robert connects Diomedes's and Vadian's definition to Celtis's concept of poetry. If this is correct, an obvious source of inspiration might have been Augustinus's dialogue, given the close relationship between Celtis and Augustinus. A further connecting point is that Vadinus wrote dedicatory poems to two works of Augustinus, the Catalogus episcoporum Olomucensium (1511) and the Antilogion Guarini et Poggii (1512). See Antonín Truhlář, Rukovět' k písemnictví humanistickému, zvláště básnickému v Čechách a na Moravě ve století XVI., (Prague: Česka akademie věd a umění, 1908), vol. 1., 72-74.

34 About Macrobius's definition of tales and its influence in $12^{\text {th }}$ century commentary literature, see the classic work of Peter Dronke: Fabula. Explorations into the Uses of Myth in Medieval Platonism (Leiden: Brill, 1977), 15-32.

35 Berlin, Staatsbibliothek, lat. fol. 335. The text of Augustinus's dialogue occupies the ff. 7r-34r, and it is preceded by the Apologia poetices of Heinrich Bebel (published in 1501) and a short excerpt "in osores poetries" from the Genealogie of Boccaccio (attributed to Boethius). See the facsimile edition in Apologia poetarum. Die Schwenter-Handschrift Ms. lat. fol. 335. der Staatsbibliothek Preussischer Kulturbesitz zu Berlin mit den Illustrationen Peter Vischers des Jüngeren, introd. ed. Franz Josef Worstbrock, Fedja Anzelewsky, 2 vols. (Wiesbaden: Reichert, 1987). 
while Saturn's castration and the birth of Venus proves that everything is born out of the sky (fig. 2.). The tale of Tiresias, who was turned into a woman, when he saw two snakes coupling and struck them with his staff, and changed back to man when he saw them again and struck them, is retold word by word by Augustinus from Fulgentius (Mit. 2, 5), together with its allegorical interpretation, according to which Tiresias is an allegory of the four seasons. Striking the snakes symbolizes spring, woman is summer, his changing to man is autumn, while his blindness is winter (fig. 3.). ${ }^{36}$

By returning to the allegorical truth hidden in it the justification of poetry was not an original motif even on the Central European literary scene. After the last two books of the Genealogie deorum gentilium of Boccaccio, a number of works - including those of Coluccio Salutati and Francesco da Fiano ${ }^{37}$ - argued in the same manner, and some of them seem to have been in circulation in the courts of East Central Europe. Here, as in many other respects, Enea Silvio Piccolomini might have played the role of mediator. As a reaction to Enea Silvio's works, Zbigniew Oleśnicki (1389-1455), the learned Polish cardinal of Cracow, summarized in 1453 all the positive knowledge he had about poets: first, the poets' intention is to direct their readers' attention towards truth: true knowledge might be moral philosophy, of physics, or simply to let the readers think about the rightness of some fictional characters and the depravity of others. As he himself reveals, he based his definition of the poet on what he picked up from the Etymologies of Isidor of Seville, suggesting that all fictional tales possess a marrow (medulla), an internal, hidden meaning. ${ }^{38}$ Later, Aelius

36 Augustinus Moravus, Dialogus, 8v, 10v. About the iconography of the illustrations of Peter Vischer the Younger, see Fedja Anzelewsky, "Die Illustrationen des Berliner Ms. lat. fol. 335.," vol. 1., 38-39, 42.

37 See Colucii Salutatis de laboribus Herculis, ed. B. L. Ullmann, 2 vols. (Torino: In aedibus Thesauri Mundi, 1951) and Maria Luisa Plaisant, “Un opusculo inedito di Francesco da Fiano in difesa della poesia," Rinascimento 1 (1961), 119-211 (with corrections from Antonio Stäuble, "Francesco da Fiano in difesa della poesia," Bibliothèque d'Humanisme et Renaissance 26 (1964) 256-259). See also Bodo Guthmüller, "Zur religiösen Polemik gegen das Studium der antiken Dichter um 1400," in Wechselseitige Wahrnehmung der Religionen im Spätmittelalter und in der Renaissance, ed. Ludger Grenzmann, Thomas Haye et al. (Berlin: de Gruyter, 2012), 93-116.

38 "Graves et egregias plerumque admiscueris sentencias in tantum quidem, ut officium poete, quo te per singulas titulasti epistolas, apprime videaris prosecutus esse. Poetarum enim, quos omnium magnarum rerum atque artium scientia nunquam latuit, intencionem in id precipue vergere comperimus, si saltem ipsorum veri estimatores sumus, ut si quid in opusculis suis fabulosum inserant, vel ad moralem philosophiam, que virtutibus hominum vitam instituit, vel ad phisicam, que nature secreta rimatur, pertinere innotescant, vel ut splendidissimis laudibus virtutum, quas per exempla clarissimorum virorum deducunt, aut viciorum dignis reprehensionibus, que per obscenorum hominum perditos mores cogitacioni nostre detestanda subjiciunt, legentium animos et oculos dulcedine delectationis alliciant. Fabule, si quidem unde dicte sint, et quis primus inventor ipsarum extiterit, queve cause illas fingendi priscos poetas impulerint, memini, me Isidorum in suis ethimologiis narrantem legisse [Isid. Etym. I, 40]: fabulas - inquit - poete a fando nominaverunt, quia non sunt res facte, sed dum taxat loquendo ficte, que ideo sunt inducte, ut mutorum animalium inter se colloquio imago quedam vite hominum nosceretur. Atque ideo non sunt poetice intelligende fabule prout cortex 
Cervinus Lampridius (or Ilija Crijević), a Ragusa-born humanist in papal service tried to promote his career at the court of Vladislas II by writing an oration praising the poets (de laudibus poetarum). ${ }^{39}$ Even Erasmus accepted in one of his earliest published works, the Enchiridion militis Christiani, that "maybe you may read with a little more profit the poetic works with allegory than the story of the holy books, if you stop at the surface." ${ }^{40}$ Interestingly, in the story of Phaëton, on one of the few occasions where Augustinus Moravus does not follow the interpretation given by Fulgentius he allegorizes the story similarly to Erasmus: the son of the Sun with his chariot fallen to the Earth is a warning against those leaders, who act temerariously. ${ }^{41}$ Erasmus interprets the story exactly in the same manner at the beginning of the Institutio principis Christiani. ${ }^{42}$ Conradus Mutianus Rufus (1470-1526), canon of Gotha, and a central figure of early 16th century German humanism, in 1505 went as far as to say that "there is but one god and one goddess, but many are their powers and names. Jupiter, Sol, Apollo, Moses, Christ, Luna, Ceres, Proserpine, Earth, Mary. But do not pronounce this. Because these are hidden by silence as the Eleusian mysteries." 43

sonat exterior, quarum si latentum medullam acumine alcioris ingenii voluerimus perscrutari, inveniemus poetarum scripturas modo naturalium rerum, modo laudabilium morum, modo egregiarum narracione historiarum ad nostre institucionem vite luculenti dogmate esse inventas." Der Briefwechsel des Eneas Silvius Piccolomini, ed. Rudolf Wolkan. Vol. 3/1, (Vienna: Holder, 1918), 247-8. (Dated Sept. 10, 1453). It went unnoticed so far that Cardinal Oleśnicki seems to have cited Francesco da Fiano in his letter. Cf. Plaisant, "Un opusculo inedito di Francesco da Fiano...," 130: "Non sunt igitur, pater optime, poetice intelligende fabule prout cortex sonat exterior, quarum si latentem medullam acumine alti velis ingenii perscrutari[s], invenies poetarum scripturas modo naturalium rerum, modo laudabilium morum, per quos virtuose vite candores acquirimus, modo egregiarum historiarum, quarum exemplis obscena horrere vite et virtutum pulchretudine delectari debere nobis ostenditur."

39 Aelius Lampridius Cervinus, Oratio ad regem Ladislaum de laudibus poetarum, Vat. lat. 1678. and Vat. Lat. 2939, 160v-166r. About Aelius Lampridius Cervinus, see Joseph Nicola Sola, "Aelii Lampridii Cervini Opera," Archivio storico per la Dalmazia, 16-19 (1933-1935), fasc. 95, 97, 98, 100, 103, 109, Darko Novaković, “Autografi Ilije Crijevića (I): Vat. lat. 1678," Hrvatska književna baština, 3 (2004), 9-251; Stanislaus Škunca, Aelius Lampridius Cervinus poeta Ragusinus (saec. XV) (Rome: Edizioni Francescane, 1971).

40 "Immo fortasse plusculo fructu legetur poetica cum allegoria, quam narratio sacrorum librorum, si consistas in cortice." Erasmus Roterodamus, Ausgewählte Werke, ed. Annemarie and Hajo Holborn (Munich: C. H. Beck, 1933), 70. Jean Seznec, The Survival of the Pagan Gods, trans. Barbara F. Sessions (Princeton: Princeton University Press, 1981), 99.

41 Augustinus Moravus, Dialogus, 11v-12r: “Quid vero poetas Phetonta finxisse credideris, nisi imperitioribus regni et imperii habenas non temere committendas esse?"

42 "Ubi Phaetontis fabulam cum voluptate didicerit, admoneat hanc esse principis imaginem, qui dum aetatis calore praeceps, sed nulla adiutus sapientia rerum habenas capessit, qui viribus quidem polleat, careat autem sapientia." Erasmus, "Institutio Principis Christiani," ed. Otto Herding, in Opera omnia Desiderii Erasmi, ordo 4, vol. 1. (Amsterdam: North Holland Publishing, 1974), 142.

43 Der Briefwechsel des Conradus Mutianus, ed. Karl Gillert (Halle: Hendel, 1890), vol. 1., 22.: “Est unus deus et una dea. Sed sunt multa uti numina, ita et nomina: Juppiter, Sol, Apollo, Moses, Christus, Luna, Ceres, Proserpina, Tellus, Maria. Sed haec cave enunties. Sunt enim occulta 
Martin Polich, an acquaintance of Bohuslaus Lobkowicz von Hassenstein, published a Laconismos tumultuarius in Leipzig in 1502, in which he defended the integrity, and partly, the superiority of poetry against theology, and claimed that poetry is a universal source of knowledge and science. ${ }^{4}$ Despite these earlier and contemporary justifications of poetry, the In defensionem poetices of Augustinus might be considered the first elaborate effort to write a defense of poetry for an audience in the Eastern and Central European area.

The defense of poetry deals only with the interpretation of poetry and gives no advice whatsoever to the question of how poetic works should actually be composed, and whether modern poetry should also contain a hidden, allegorical message. Although our knowledge about the poetic output of Augustinus is relatively scarce, ${ }^{45}$ on the basis of his surviving work we may guess that he had a penchant for allegorical descriptions in actual poetic works, too. The Treni neglecte Religionis (A mourning song of the neglected Religion), a hitherto unnoticed poem of Augustinus addressed to King Vladislas II, is attached to an oration held in Buda in 1500, in which the Venetian Sebastiano Giustiniani asked for help against the Turks from the king of Bohemia and Hungary. ${ }^{46}$ The Treni depicts Religion as a Lady, using the rhetoric tools of prosopopoeia and personification, as she stands in front of the king in tattered dress and implores him for help against the Turks. Lady

silentio tamquam Eleusinarum dearum mysteria. Utendum est fabulis igitur atque enigmatum integumentis in re sacra [...] quum Jovem nomino, Christum intelligo et verum Deum." See also Fidel Rädle, "Mutianus Rufus, Conradus," in Verfasserlexikon: Deutscher Humanismus 1480-1520 (Berlin: de Gruyter, 2011), c. 377-400, here c. 391.

44 Susann El-Kholi, "Martin Polich von Mellerstadt," in Verfasserlexikon: Deutscher Humanismus 1480-1520 (Berlin: de Gruyter, 2012), Bd. 2., 513-514; Gustav Bauch, Geschichte des Leipziger Frühhumanismus: Mit besonderer Rücksicht auf die Streitigkeiten zwischen Konrad Wimpina und Martin Mellerstadt (Leipzig : Harrassowitz, 1899), 114-129. and Volhard Wels, Der Begriff der Dichtung in der Frühen Neuzeit (Berlin: De Gruyter, 2009), 246-248. Wels suggests (p. 247, note $35)$ that one of Polich's sources was Bartolommeo della Fonte (Fontius).

45 See the study of Christian Gastgeber in this volume about the limited circulation of his poems.

46 Augustinus Doctor [=Augustinus Moravus], "Treni neglecte Religionis ad Vladislaum Pannonie Boemieque Regem Inuictissimum," in Sebastiano Giustiniani, Oratio magnifici et clarissimi D. Sebastiani Iustiniani oratoris Veneti ad Serenissimum Dominum Vladislaum Pannonie et Bohemie regem ([Leipzig]: [Stöckel], 1500), B2v-B3v. (ISTC ij00612700, GW M15600). I have used the digital edition of the Wolfenbüttel copy: http://diglib.hab.de/inkunabeln/202-69quod-1/start.htm, accessed on 12.12.2014. Truhlár knew about this poem from a note of Michael Denis, but he could not find the text itself. Cf. Truhlář, Rukovět'..., vol. 1., 74. Valentin Eck might have taken the theme of his own Threni neglectae religionis (Cracow: Haller, 1518) from Augustinus Moravus. On the historical background of the oration, a possible league of Hungary with France and Venice against the Turks, see Balogh István, Velencei diplomaták Magyarországon. 1500-1526., [Venetian diplomats in Hungary 1500-1526] (Szeged: s.t., 1929), 11-26. and Giuseppe Gullano, "Sebastian Giustiniani," in Dizionario biografico degli Italiani, vol. 57 (2001), 290-296. Augustinus's poem hints at this league ("Cernis ut invicto procedat robore Gallus, // Hunc contra socia et iungere signa parat // Adriaco Veneti mittunt et ab aequore patres...", Oratio, b3r), which was the purpose of Giustiniani's mission. 
Religion uses mythological deities to describe the characteristics of king: his mental skills were given to him by Pallas, the strong arms come from Bellona, his eloquence from Mercury (Cinthius), his peacefulness from Jupiter and his weapons from Mars (lines 5-8). The use of the allegorical narrative both on the level of narrative (Religio as a prosopopoeia) and as rhetoric adornments (Pallas, Bellona, Jupiter, Mars) shows that allegory was not only a historical phenomenon, but it could be used in contemporary poetry, as well.

In sum, I have tried to demonstrate that Augustinus does more than simply copy the arguments of the most important Renaissance apologetics of poetry, Boccaccio and Petrarch, adding evidence from ancient allegorical literary interpretation, from Macrobius and Fulgentius. Recently, Franz Josef Worstbrock has pointed out that despite its merits, namely closely imitating the structure and the style of Platonic dialogues and its literary value, it adds nothing original to the poetic theories of the Renaissance, as it concentrates only on the allegorical interpretation of the myths as the only method to safeguard the moral and philosophical integrity of poets and poetry. ${ }^{47}$ In fact, we may better understand his efforts, if we consider them as modernization of the widespread and often repeated contentions in the defense of poetry. It is obvious from his dedicatory letters and the Defense that despite his young age -26 at the time of the publication-Augustinus tried to present himself to his audience at home as a man with a mission: as someone who is convinced of the righteousness of his humanistic ideals and of the superiority of the knowledge of his age compared to the dark ages that preceded his own century. In his In defensionem poetices, the detailed comparison of poetry with medicine serves not only to demonstrate the inferiority of the medical use of language, as compared to the purity of Latin poetry-an argument that has been well exposed already in the Invectivae contra medicos of Petrarch. Augustinus Moravus - unlike the Italian master humanist - points also to the common root of poetry and medicine, their oracle-like character and their cosmic-astrological correspondence. Drawing on a large number of late antique and Renaissance sources (Macrobius, Fulgentius and Petrarch among others), Augustinus has created a synthetic defense of poetry, in which the traditional lines of controversy, according to which poetry is exempt of the pursuit of material interests and it contains a hidden, allegorical meaning, are melted with astrological and moralizing arguments. It might have been exactly its synthetic character which made this dialogue popular among contemporary humanists and worthy of an iconographic program in the Apologia poetarum. Throughout, this synthetic approach to the defense of poetry is related to the idea of the survival and transmission of ancient wisdom, which is so palpably present in the dedications of Augustinus to his other works.

47 Apologia poetarum, ed. Worstbrock, 20-21. 



\title{
ÁDÁM SMRCZ \\ The Portrait of Bassareus Medicus (Conrad Celtis and Augustinus Moravus)
}

\author{
"Nullaque de nostris edentur carmina libris \\ Quin partem in illis occupes."
}

(Conrad Celtis, In Bassareum Medicum, 41-42.)

\section{Introduction}

Bassareus Medicus is a strange and mysterious character, who two members of the Sodalitas Litterarum Danubiana refer to: he appears in Augustinus Moravus's symposium-like dialogue In Defensionem Poetices, and is also the addressee of Conrad Celtis's epode, In Bassareum Medicum. In the first case he is portrayed as a hedonistic clown, while in the second he appears as a calumniator.

My paper's aim is twofold: firstly I suggest that this correlation is not simply accidental (i.e. both authors refer to the same person, regardless of the fact that his identity remains unknown); secondly this paper intends to reveal the nature of Bassareus's character by investigating the possible origin and connotations of his name.

Based on the previous assumptions, my suggestion is that the combined reading of the two literary works may explain each other, and hence provide us with a deeper understanding of both. First of all, indeed it is the clown of In Defensionem Poetices who is mainly reliant on such highlighting, since Augustinus's poor portrait of him raises the reader's serious doubts about the dramaturgical role of this character, while Celtis's reference to Horace-as we shall see-clarifies at least a few things (e.g. that Bassareus must have been the object of some sort of animosity).

\section{"The strict rule of meat" - or Bassareus portrayed by Augustinus Moravus}

In his 1493 work, Augustinus Moravus deals with the popular Renaissance topic whether poetics or natural sciences prevail (and hence should be revered more). The text mainly bears testimony of a dispute between the two major characters, Laelius and Augustinus (the latter most probably echoes Moravus's 
own opinion), but the author stages a third person as well: Bassareus, a rather enigmatic character who takes part in the conversation for a very short period (two separate entries only), then disappears. Rather than adding anything to the conversation, this mysterious character with an unclear role tends to break the line of thought.

The mere employment of Bassareus approximates the work to the genre of symposium texts, where clown-like figures are intended both to amuse the reader and help the conversation progress: this is what comes to our mind when we recall e.g. Alcibiades's character in Plato's or Galeotto Marzio's portrait in Bonfini's text. Albeit it is a well-known convention to employ clown-like figures in such works, Bassareus can still be regarded as poorly portrayed: not only does he speak about off-topic themes, but rather than developing the plot further, he tends to break it.

"I'm coming directly from the public house" ${ }^{1}$-this is what he tells us right at his first appearance, without being asked at all about his whereabouts. Augustinus, however, labels his arrival as agreeable ("amicus noster [...] opportune adproperat"), but what we learn about his relationship with Bassareus renders the statement rather ironic: "Is it he whom you had to pick up from the road the other day?" Laelius asks. And Augustinus's answer is affirmative: "It's him, indeed."

Also without being investigated, he goes on with his complaints in an almost philosophical manner:

It is all the way true as some say it: when fortune diminishes, nothing good can happen to men. Hence, as I do want to fill my stomach with fine dishes today, and as a man bearing his hunger, turn to whatever public house the gods or goddesses provide me: I want to ease my unbearable hunger following the strict rule of meat. ${ }^{3}$

Bassareus hence appears on the scene confessing - not under any external force-that the jus carnium means the only regulating principle for him, resulting in a quasi-deterministic relationship between himself and worldly pleasures. Not having any free will, Bassareus hence seems to lack any kind of human dignity.

1 “Bas.: E caupona recta descendo." Augustinus Moravus Olomucensis, Dialogus in defensionem poetices, ed. Karel Svoboda (Prague: Česka akademie věd a umění, 1948), 17.

2 "Lae.: Illene quem nudiustertius ex itinere venientem susceperas? Au.: Ille scilicet". Augustinus Moravus Olomucensis, Dialogus in defensionem poetices, 17.

3 "Bas.: Ita est profecto quod aiunt. Nihil fortuna rennuente posse homini satis dextrum accidere. Namque ego dum lautioribus hodie cibis aqualiculum meum saginare discupio atque ob id ad cauponem quendam (quem dii deaeque prodant) famigerabilis diuerto: exiguo iure carnium, eoque macro atque insipido, famem intolerabilem compescere cogor." Augustinus Moravus Olomucensis, Dialogus in defensionem poetices, 17. 
In order not to waste their time further ("ne hic hora praetereat"), Laelius suggests that he and Augustinus walk on to the place previously discussed so that they can conduct their conversation, an idea which Augustinus approves of: "Indeed, it's a good idea. And you, Bassareus, please follow us more slowly - as you generally do-and quicken your steps only carefully." 4

After supposedly leaving Bassareus behind, the two participants find a suitable place for their conversation and start talking about the practical virtues and moral vices of medical scientists. Later on, when Bassareus reappears, Augustinus - trying to involve him in the conversation - asks him to share his opinion about Bologna. In fact, the dramaturgy employed here is quite elliptic since we only suspect but cannot be sure that Bassareus had earlier been left behind, while his reappearance is introduced merely by an invocation ("Sed heus tu Bassareu venustule noster") without providing any information about his whereabouts. The reader witnesses a similar lack of explicity, when-not much later-Bassareus suddenly disappears, and does not return anymore. Mainly compared to the rhetorical perfection of the other two characters, Bassareus seems to be fairly imperfect. A literary work principally aiming at poetic excellence via the recapitulation of well-known topoi (and not aspiring for e.g. philosophical originality via sound arguments) could hardly afford such poor methods of dramaturgy.

As we would guess, Bassareus's appearance is rather disturbing here again, since it is because of him that Augustinus and Laelius cannot reach a conclusion concerning their current field (as they were about to praise poetics right then). Augustinus mentions that in Bologna "medical sciences are said to be of a high standard, and the habit of Bassareus reminds him of a doctor." 5 Augustinus calling him a doctor anticipates another meaningless monologue, the intention of which would be to solve the problem in question. Here, again in a hedonistic manner, Bassareus continues to talk about dining, drinking and other pleasures of life. After a short allusion to the city of Bologna, where medical sciences were said to prevail, he begins the explanation of the pleasures provided by Italy's climate:

Listen to me now, and since it was your order, consider everything more carefully after my word: since the soil of Bologna [...] easily surpasses each and every city of Italy due to its so many excellent things. Since one can find there such abundance of wine (tanta Liberi copia) and such a great variety of

4 "Aug.: Immo uero perplacet. Tu tamen Bassareu, uti soles, lentius nec nisi protentato passu cautius subsequere." Augustinus Moravus Olomucensis, Dialogus in defensionem poetices, 17.

5 "Aug.: [...] Bononiae enim ea studia imprimis uigere dicuntur. Et habitus iste tuus [...] medicum prodit." Augustinus Moravus Olomucensis, Dialogus in defensionem poetices, 22. 
dishes that while particular cities are adorned by particular gifts, Bologna is said to be the soil fat and fertile in everyone's peculiar oration. ${ }^{6}$

In his monologue, he emphasizes the importance of Italy's fine climate, and also comes back to the abundance of wine and wheat ("vini Cererisque copia"). Yet this is his last appearance in the dialogue, since after this speech he does not play any more part in the conversation.

Later on, the two other participants reach their conclusion about a certain balance concerning the dispute about the prevalence of poetics or natural sciences, but this still has nothing to do with Bassareus's remarks. The question remains open: what did Bassareus add to the line of thought, or why did he appear on the scene at all? Luckily, we have the opportunity to widen the context further by taking into consideration another work also linked to him.

\section{"The illness of envy" - or Bassareus portrayed by Conrad Celtis}

While Bassareus is merely a minor character in Augustinus's work, he appears much more clearly in Conrad Celtis's poem. The epode makes a clear reference to Epode VI of Horace by invoking an intertextual context. Besides the metrical coincidence between the two, Celtis begins his verse with the dog metaphor (a metaphor also employed by Horace in the so-called Reply to the Blackmailer) ${ }^{7}$. Here again this intertextual reference helps us highlight the role of the dog, whose barking - in Horace's case - turns out to be ineffective after having revealed the hypocrisy behind it: confronting wolves, the barking dog suddenly becomes shy ("ignavos adversum lupos").

This analogy is of double importance for us: (1) firstly it sheds light on the role played by the dog in Celtis's poem, intimating that staining one's fame by "furious growling" is necessarily pointless; (2) secondly this is the point where

6 "Bas.: Animaduertite igitur (quam ita constituistis), et ab ore meo diligentius cuncta pensate: Bononiense solum, cum ex multis praeclaris rebus [...] singulas Italiae civitates facile superat, quod in eo tanta Liberi copia inueniatur, tanta obsoniorum omnium uarietas, ut quom singulae urbes singulis aliquibus dotibus illustrentur, Bononia ab omnibus peculiari deuerbio terra pinguis et fertilis dicatur." Augustinus Moravus Olomucensis, Dialogus in defensionem poetices, 23.

7 "Quid canibus similis rabido me murmure laedis / vastis premens latratibus, / denigrasque meam rabioso gutture famam, nostris Camenis obstrepens,". Conrad Celtis, "In Bassareum Medicum," in Conrad Celtis, Oden, Epoden, Jahrhundertlied-Libri Odarum quattuor, cum Epodo et Saeculari Carmine (1513), ed. Eckart Schäfer (Tübingen: Narr Francke Attempto Verlag, 2012), 332-335. "Why do you keep striking me with your furious growling, so similar to that of dogs, while letting your brute barking heard? You stain my fame with your insane throat, while talking down our muses"; "Quid inmerentis hospites vexas, canis / ignavos adversum lupos?" "Why are you tormenting innocent guests you bastard / who is so shy when confronting wolves" (Horace, Epode VI, 1-2.). 
the parallel between Bassareus's portrait by Celtis and the one by Augustinus Moravus are the most similar: both sketch him as a kind of braggart providing unreliable information.

Later on, Horace's example becomes much less palpable, since Celtis starts unfolding Bassareus's inner properties: one learns that the addressee feels envy towards the lyrical self, and this envy is caused by melancholy:

Putrida cui sanies confuso felle veneni iecur lacessit invidum, ${ }^{8}$

(For whom the rotten pus mixed with the poisonous gall incites an envious liver,)

But no matter how vehemently the opponent feels, it rather helps to develop virtue in those who suffer such injustice: had not Ovid or Cicero been expelled from Rome, had Virgil not been forced to abandon his parental property, their oeuvre would not be considered so glorious today.

Quod si de Roma non pulsus Naso fuisset

Ponti remensus litora,

non tot liquisset praeclara volumina vates

cunctis legenda saeculis; ${ }^{9}$

(Had not Naso been expelled from Rome having to stay by the shores of Pontus, he would not have left his poetic volumes behind the ones to be read for all centuries to come.)

From the conclusion of the poem, we learn about the everlasting glory of the one who suffers innocently, and the failure of the "blackmailer".

The problem is that while Augustinus's dialogue intimated a correlation between Bassareus, the hedonistic clown and viniculture-as the name itself would suggest-Celtis's portrait bears no trace concerning any relationship between Bassareus and Dionysus: his poem implies a slightly different character. One possible resolution could be that his poetic sources might have been different (as we shall see below).

8 Conrad Celtis, "In Bassareum Medicum," in Conrad Celtis, Oden, Epoden, Jahrhundertlied ..., 332.

9 Conrad Celtis, "In Bassareum Medicum," in Conrad Celtis, Oden, Epoden, Jahrhundertlied ..., 332. 


\section{The connotations the name Bassareus might bear}

Having observed the most important attributes the two portraits transmitted to us, we can state in both cases Bassareus appears as an unreliable character (e.g. telling falsehoods about Bologna in one case, and lying about a particular person in the second).

Such similarities, along with the strange name itself, provide us firm ground to assume that the reference of both works was the same, supposedly hostile person, althought neither of the writings offers more than an elliptic enumeration of his attributes: in Moravus's case there is no trace of calumny, while Celtis does not refer to hedonism at all. Even if not in full, a short glance at the origin of Bassareus's name might complement these gaps.

In many places, Augustinus employs word by word quotations from Macrobius. One such piece of evidence can be found between Bassareus's two appearances. ${ }^{10}$ This correlation is important for us because Macrobius himself was one of the very few authors ${ }^{11}$ who dealt with a so-called Bassareus in his Saturnalia:

Item Liberi patris simulachra partim puerili aetate partim iuvenis fingunt:

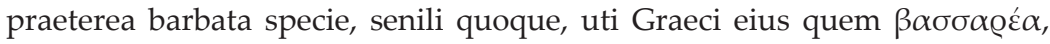
item quem B@ıøé $\alpha$ appellant [...]

(Likewise the portraits of Liber Pater were crafted partly in infantile, partly in juvenile age. But furthermore he was also portrayed with a beard in an elderly age, as the Greeks called him $\beta \alpha \sigma \sigma \alpha \varrho \varepsilon ́ \alpha$, likewise whom they called

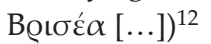

Taking this report into consideration, we learn about the sameness of Liber Pater (a Roman god of viniculture) and Bassareus. This Dionysian character not only coincides with Augustinus Moravus's portrait of Bassareus, but Bassareus's reference to wine as "Liberi" even reinforces our assumption. The Greek expression, $\beta \alpha \sigma \sigma \alpha \varrho \varepsilon ́ \alpha$ itself might refer to the type of clothes the

10 "...siquidem medicinae atque divinationis (ut Macrobius meminit) consociatae sunt disciplinae. Nam medicus vel commoda vel incommoda in corpore futura praenoscit [...]". "If the arts of medicine and divination are associated (as Macrobius reminds us), then a doctor could foretell the forthcoming commodities or incommodities of bodies [...]". Augustinus Moravus Olomucensis, Dialogus in defensionem poetices, 19.

11 Although textual evidence does not provide us with direct proof that Marsilio Ficino would have been the source for Bassareus, it is still worth mentioning him as one of the very few authors citing his name: "Ergo in elemento terrae illam vim Plutonem Orpheus nominat, hanc Proserpinam; in aqua Oceanum illam, hanc Thetim; [...] Martis Bassareum atque Clionem". Marsilio Ficino, Platonic Theology. Volume I., ed. James Hankins (Cambridge: Harvard University Press, 2001), 295. Obviously, Ficino attributes Bassareus a completely different character, namely one corresponding with the power of Mars.

12 Macrobius, Saturnalia, ed. Robert A. Kaster (Harvard University Press, 2011), 248-249. 
followers of Dionysus wore; the adjective (so the direct origin of the word) might signify the man who wears $\beta \alpha \sigma \sigma \alpha \varrho \varepsilon$, $\alpha$, the man who follows Dionysus. ${ }^{13}$

\section{Conclusion}

With the two portraits at hand our aim was to establish a list of Bassareus's attributes, enjoying the benefits a combined reading could offer.

In conclusion, we can say that the most likely origin of Bassareus' character was a Thracian god of viniculture, an assumption which is reinforced even by textual correspondence in Moravus's case. None of the very few sources concerning Bassareus is likely to come into consideration, but even if any did, one important point would still prove true: none of them mentions any sort of medical attribute concerning him, hence no "Bassareus Medicus" can be found beyond the threshold of the Sodalitas.

Keeping in mind, that no trace of any other source can be found, we may conclude, that not only is the two characters' reference the same, but that the two authors served as a source for each other. If this proves true, it would likely follow that Augustinus must have been the first to employ the alleged character, and Celtis came second to him. Still Bassareus's portrait by Moravus is so elliptic that any interpretation necessarily requires the involvement of intertextual loci. 



\title{
PÉTER EKLER
}

\section{Augustinus Moravus's De modo epistolandi}

\author{
The Letters of Augustinus Moravus Olomucensis to \\ Heinrich Oswein, Andreas Stiborius, Filippo Beroaldo \\ and Cassandra Fedele*
}

There are a number of open questions and problems related to the literary activity of Augustinus Moravus, who died 500 years ago. Among them there is the thorough investigation of Augustinus's De modo epistolandi cum nonnullis epistolis quam pulcherrimis (hereafter: De modo epistolandi), a stylistic "coursebook" to teach letter-writing, published in Venice, Italy in $1495 .{ }^{1}$

The present study undertakes to scruitinize four letters in the De modo epistolandi, namely the dedication, and the "sample letters" 1., 4. and 5. to interpret the biographical conclusions drawn.

The De modo epistolandi is a short and simple manual teaching letterwriting in a clear structure. After the general description of the genre (fol. $\left[\right.$ Aii $\left.\left.-\mathrm{B}^{\mathrm{v}}\right]\right)$, it follows the train of thought in book four of the Rhetorica ad Herennium ( $1^{\text {st }}$ century BC) and presents the various rhetorical devices (fol.

* The present paper has been produced with a grant from János Bolyai Research Scholarship of the Hungarian Academy of Sciences (BO/00177/13/1), and with the support of my employer, the National Széchényi Library. I am grateful to the following people for the useful advice and information they have provided me with: Marta Vaculínová, Emőke Rita Szilágyi, John Monfasani, Roman Mazurkiewicz, Michael Moser, Petr Mata, Árpád Mikó, Barnabás Guitman, Tamás Fedeles, Farkas Gábor Kiss.

1 About the life and activity of Augustinus Moravus Olomucensis and De modo epistolandi, see Gustav Bauch, "Zu Augustinus Olomucensis," Zeitschrift des Deutschen Vereins für die Geschichte Mährens und Schlesiens 8 (1904), 119-136; Rukovět humanistického básnictví v Čechách a na Moravě. Enchiridion renatae poesis Latinae in Bohemia et Moravia cultae, založili Antonín Truhlář a Karel Hrdina, pokračovali Josef Hejnic a Jan Martínek. Vol. I. (Praha, 1966), 111-116; Ivo Hlobil and Eduard Petrů, Humanism and the Early Renaissance in Moravia (Olomouc: Votobia, 1999), 157158; Eduard Petrů, “Augustin Olomoucký a česká epistolografie," Česká literatura 49 (2001/6), 564-571; Ralf Georg Czapla, "Augustinus Moravus," in Deutscher Humanismus 1480-1520. Verfasserlexikon, edited by Franz Josef Worstbrock (Berlin-New York, 2005), vol. I, 61-72. Péter Ekler, "Classical Literature as a Model and Standard in the 'De Modo Epistolandi' of Augustinus Moravus Olomucensis," in Investigatio Fontium: Griechische und lateinische Quellen mit Erläuterungen. Beiträge der Tagung Klassisches Altertum-Byzanz-Humanismus der XI. Ungarischen Konferenz für Altertumswissenschaft, edited by László Horváth, 159-169. (Antiquitas-Byzantium-Renascentia; 10.), (Budapest: ELTE Eötvös József Collegium, 2014). 
$\left[\mathrm{B}^{\mathrm{v}}\right]-\mathrm{C}$ ), and finally gives thirteen letters in Latin as positive examples (fol. Cii-[Diii]). ${ }^{2}$

The De modo epistolandi was published once only (in 1495), has no modern issue, and as already mentioned, little attention has been given to the letters it comprises.

On the other hand, many of the letters by Augustinus Moravus addressed to others (e.g. Conrad Celtis, Bohuslav Hasištejnský z Lobkovic/Bohuslav Lobkowicz von Hassenstein) not included in the De modo epistolandi can be studied in modern editions as well. ${ }^{3}$

Thus in the present study, it appears justified to make some adjustments to Augustinus's biography through the analysis of the De modo epistolandi letters, namely the dedication letter, and letters 1, 4 and 5 of the collection.

\section{The dedication ${ }^{4}$}

Augustinus Moravus dedicated the De modo epistolandi to "Henricus Oseuen" (Heinrich/Henryk Oswein, ?-1516), canon of Wrocław and dean of Głogów. ${ }^{5}$ Heinrich Oswein was related to the well-educated Johannes IV (Roth) (14261506), the bishop of Wrocław, who similarly to Augustinus, also studied in Padua. Johannes IV (Roth) - besides Augustinus's uncle Andreas Stiboriuswas one of Augustinus's main supporting patrons. Augustinus dedicated his

2 My study relies on the copy of the exemplar kept in Munich (Bayerische Staatsbibliothek, $4^{\circ}$ Inc. c. a. 1228).

3 Der Briefwechsel des Konrad Celtis, gesamm., hrsg. und erl. von Hans Rupprich (Veröffentlichungen der Kommission zur Erforschung der Geschichte der Reformation und Gegenreformation. Humanistenbriefe, 3), (München: Beck, 1934); Bohuslai Hassensteinii a Lobkowicz epistulae, ediderunt Jan Martínek et Dana Martínková (Leipzig: Teubner, 1969-1980), tom. 2. Epistulae ad familiares.

4 Péter Ekler, " 'Epistolaris itaque formula attenuato stilo ducetur potissimum...' Az ideális stílusnem kérdése Augustinus Moravus Olomucensis De modo epistolandijában," in Convivium Pajorin Klára 70. születésnapjára, ediderunt Enikő Békés et Emericus Tegyey. (ClassicaMediaevalia - Neolatina VI.) Societas Neolatina Hungarica, Sectio Debreceniensis; Institutum Doctrinae Litterarum Academiae Scientiarum Hungaricae, Debrecini et Budapestini MMXII, 75-81.

5 "Opusculum componendarum epistolarum familiarium Augustini moraui Olomucensis decretorum atque Artium liberalium doctoris ad Henricum Oseuen Decanum glogouiensem et canonicum Vratislauiensem." (fol. A [recte: Aii ${ }^{r}$ ]). For Heinrich Oseven (Oswein), see Gustav Bauch, "Beiträge zur Litteraturgeschichte des schlesischen Humanismus. VI.," Zeitschrift des Vereins für Geschichte und Alterthum Schlesiens 38, (Breslau, 1904), 318-319; Gustav Bauch, "Analekten zur Biographie des Bischofs Johann IV. Roth," in Darstellungen und Quellen zur schlesischen Geschichte. Herausgegeben vom Verein für Geschichte Schlesiens. Dritter Band. Studien zur schlesischen Kirchengeschichte, (Breslau, 1907), 97-101; Kapituła głogowska w dobie Piastowskiej i Jagiellońskiej (1120-1526), edited by H. Gerlic (Gliwice, 1993), 221-222. I am grateful to Emőke Rita Szilágyi, Barnabás Guitman, Tamás Fedeles, and Roman Mazurkiewicz for their assistance in identifying Heinrich Oswein. The full text of the letter is published in Péter Ekler, "'Epistolaris itaque formula attenuato stilo ducetur potissimum...' ", 80-81. 
Dialogus in defensionem poetices (Venice, 1493, GW 3057) to him. In recalling the Padua years in the dedication of the Dialogus, he mentions a young man related to Bishop Johannes IV (Roth) (“...Henricum, consobrinum tuum, rarae indolis adolescentem..."), who is very likely to be identical with Heinrich Oswein. ${ }^{6}$ If there is the same Heinrich in the two dedication letters (Dialogus, De modo epistolandi), then it is obvious that through him, the dedication to De modo epistolandi was addressed also to the highly educated Wrocław bishop. ${ }^{7}$

Opusculum componendarum epistolarum familiarium Augustini moraui Olomucensis decretorum atque Artium liberalium doctoris, ad Henricum Oseuen Decanum glogouiensem et canonicum Vratislauiensem. (fol. $\mathrm{A}^{\mathrm{r}-\mathrm{v}}$ $\left[\right.$ recte: $\left.\left.\mathrm{Aii}^{\mathrm{r}-\mathrm{v}}\right]\right)^{8}$

DOleo interdum, mi Henrice, quom quorundam non minimi etiam nominis epistolas intueor, intra me non parum stomachari, hominum aeui nostri inerciam detestatus, qui a familiari illa puri sermonis consuetudine ita in epistolari hoc officio attolluntur, ut nullum penitus texendae orationis et epistolaris imaginis in his discrimen inueniatur. Quin eos uel tumidos uideas, obscuros, affectatos, tinnulos et quocunque alio cacozeliae genere, ut Quintiliani uerbis utar, lasciuientes. ${ }^{9}$ Neque id solum uerborum structura delectuque quodam exquisitiore admittunt. Sed ut numeros omnes absolute dictionis implesse uideantur, rem ipsam et altius etiam exordiuntur, Narrationem subiiciunt, propositionem, eius deinde confirmationem, contrariorum confutationem, excursionem, et quod in oratione est ultimum, causae etiam perorationem annectunt, Eorum fortasse preceptis admoniti, qui in libellis ipsorum, quos rhetoricos inscribunt, eisdem, quibus orationem partibus, epistolam etiam depingunt. Quin etiam, ne quid ad perfectionem desit, figuras uerborum et sententiarum per omnem passim orationem ita disparciunt, ut eis tanquam floribus quibusdam et pigmentis, totus ille sermonis contextus respersus uideatur. Argumentorum etiam sedibus, quibus orationes ipse potissimum referciuntur, usque adeo impliciti, ut his et sylogismos enthymemataque intorqueant, et pro uarietate enthymematum, hic elentico, illic gnomico, dictico rursus aut paradigmatico concertent, ignari quanta in stilo sit uarietas, ubi uel oratio texenda sit, uel epistola, hystoria uel priuata res aliqua, res grauis, eaque rursum humilis uel media, ita scilicet in omnibus eodem orationis habitu sibi incedendum existimant.

6 Augustini Olomucensis Dialogus in defensionem poetices, edited by Karel Svoboda (V Praze: Nákladem České akademie věd a uměni, 1948), 14.

7 For this question, also see the article by Emőke Rita Szilágyi in the present volume.

8 The full text of the letter was first published in 2012: Péter Ekler, " 'Epistolaris itaque formula attenuato stilo ducetur potissimum...' ", 80-81. We are grateful for the opportunity of being able to publish it again in the present volume.

9 Quintilianus, Institutio oratoria, 8, 3, 56-59. 
Qui si Ciceronem, Quintilianum, Anneumque Senecam paulo accuratius diligentiusque explicuissent, quanta in his singulis stili disparitas esse debeat, facile obseruauissent. Lege ad Herennium Tullii libros, inquit diuus Hieronymus, lege rhetoricos eius, reuolue tria uolumina de oratore, in quibus introducit eloquentissimos illius temporis oratores Crassum et antonium disputantes. Et quartum oratorem, quem iam senex ad Brutum scribit, tunc intelliges aliter componi hystoriam, aliter orationes, aliter dialogos, aliter epistolas, aliter commentarios. ${ }^{10}$ Quis nescit, inquit Cicero, primam historiae legem, nequid falsi dicere audeat, huiusqueexedificationem positam esse in rebus et uerbis, rerum ratio ordinem temporum desiderat, regionum descriptionem, consilia euentus. Verborum autem ratio, genus orationis fusum arque[!] tractum, cum lenitate quadam aequabili profluens, sine iudiciali asperitate et sine sententiarum forensium aculeis. ${ }^{11} \mathrm{Et}$ in bruto de Caesaris commentariis. Commentarios, inquit, scripsit ualde quidem probandos, nudi sunt recti et uenusti, omni ornatu orationis tanquam ueste detracta. Sed dum uoluit alios habere paratam, unde sumerent, qui uellent scribere historiam, inaeptis gratum fortasse fecit, qui illa uolunt calamistris inurere, Sanos quidem homines a scribendo deterruit. ${ }^{12}$ Quod si in historia scribenda calamistris, quemadmodum Cicero ait, uti non licet, quanto id minus in familiari epistola permittitur. Quae ut idem de claris oratoribus ait, non, nisi quotidianis uerbis contexitur. ${ }^{13}$

Vt igitur is error, qui longe lateque inualuit, posthac facessat, presens opusculum componendarum epistolarum condere institui. In quo si tibi studiosisque opere precium fecisse uidebor, gaudebo equidem me hanc operam frustra non suscepisse. Sin minus, aliis tamen uiam aperuero, ut quod minus ipse consequi ualui, accuratoribus ipsi praeceptis, si ea res tamen preceptis tradi potest, in communem omnium utilitatem exhibeant. Vale.

\section{Letter 1}

Augustinus was born in Olomouc (Olmütz) in 1467. He lost his father, Aegidius very early. The author of the De modo epistolandi, however, received a very good education through his uncle on his mother's side, Andreas Stiborius (Ctiborius) the canon of Olomouc, who died in 1496. His name appears in different forms (Ctiborius-Stiborius), but he should not be confused with the Viennese scholar Andreas Stiborius (ca. 1470-1515).

10 Hieronymus, Apologia adversus libros Rufini missa ad Pammachium et Marcellam, liber I, 471. (PL 23 (1883), col. 428)

11 Cicero, De oratore, 2, 15, 62-64.

12 Cicero, Brutus, 262

13 Cicero, Epistolae familiares, 9, 21 
Augustinus began his studies in Olomouc. In 1484 he started his studies at the University of Cracow, and received a bachelor's degree on $20^{\text {th }}$ September 1486, and a master's degree in arts (artes) at the end of 1487 or in 1488. Subsequently, with the financial help of his uncle and Johannes IV (Roth) the Bishop of Wrocław, he started his studies of law in Padua. The letter at the head of the collection is a nice document of deep love and genuine gratitude to the uncle, as well as an important source for Augustinus's childhood and early years: It is clear that for the orphaned Augustinus, his uncle meant solid support in a hard life, as he was the one who helped him in getting his education in Cracow and Padua. ${ }^{14}$

This is not the only letter attesting to Augustinus's gratitude to his uncle. The name of Andreas Stiborius appears in Augustinus's other printed works too. He is the one addressed in the letter at the end of the prognosticon for the year 1492 (Venice, after 13 ${ }^{\text {th }}$ November 1491, GW 3059) ("Augustinus Olomucensis Andree Stiborio, canonico olomucensi, Auunculo suo. S."), in the letter at the end of Dialogus in defensionem poetices (Venice, 1493) ("Augustinus Olomucensis Andreae Stiborio, canonico Olomucensi, avunculo suo s. p. d."), ${ }^{15}$ and in the dedication at the head of the Johannes Blanchinusedition (Venice, 1495, GW 4410) ("Augustinuus[!] Morauus Olomucensis Jurispon. atque artium doctor Andree Stiborio, Canonico Olomucensi, Auunculo suo Salutem plurimam dicit."). In all of the four cases, namely in the letter featuring in the De modo epistolandi, and the three editions listed, Augustinus turns to Andreas with the words "amice beneficentissime," thus referring to his uncle's spiritual and moral sacrifices for his sake.

Although De modo epistolandi does not start with a dedication to Andreas Stiborius, the letter to him is at the head of the sample letters, and in it Augustinus Moravus starts by clearly stating ("...non, nisi nomine tuo insignitum emanet..."; "...tibi non imputem primum?") that he is dedicating De modo epistolandi also to his uncle, who was a true father figure replacing his own father.

AVG. MORA. Olom. Andreae Stiborio Auunculo suo. S. (fol. Ciir)

EXigit a me pietas humanitasque tua, Andrea stibori, amice beneficentissime, Vt si quid unquam ex eo, quantulumque in me ingenii est, elaboratum effluxerit, Non nisi nomine tuo insignitum emanet adeo, ut quum diebus superioribus opusculum quoddam componendarum epistolarum excudissem, Nephas mihi ducerem, nisi id gratitudinis erga te meae significationem aliquam praestaret. Tot enim tantaque tua in me sunt collocata beneficia, ut in eis uel recensendis, unde mihi ordiendum sit

14 "AVG. MORA. Olom. Andreae Stiborio Auunculo suo. S.", fol. Ciir. In 1904 G. Bauch published the entire letter: Bauch, "Zu Augustinus Olomucensis...", 123-124. 
potissimum, difficile inueniam. Nam si a puero tenerisque annis incipere uolo. Tu uagientem adhuc, quum patrem meum optimum atque integerrimum uirum nondum in lucem editus amisissem, primis illis infanciae crepundiis ornasti. Nihil in me praetermittens, quod boni parentis cura solicitudoque prestare potuisset, Hinc orbitatis meae motus inuidia, Illinc uero, quum aduersis quibusdam post recens funus, uixdum natus inpeterer, inpotentis et infantiae misericordia commotus. Qui etiam ne maternis deliciis defluerem, quae orbitatem suam hoc uno sibi superstite solacio consolabatur, plus aequo tenerae illi aetati meae indulgens, abstrahendum potius arbitratus es, quam huiusmodi deliciis asuescens omnem deinceps uitam turpi ocio mollisque uitae consuetudine traducerem. In ea me apud te uitae continentia, Morum sanctimonia Bonarumque artium exercitatione assidua instituens, ut omne, quod ingenio uel doctrina assecutus sum, id totum tibi uni se debere fateatur. Qui ubi etiam ad id aeui me perductum uideres, in quo uberiores iam ingenii fructus colligere possem. Non contentus me Cracouiense gymnasium adiisse, in quo philosophiae penetralia perciperem. Nisi patauium etiam omnium bonarum artium parentem adirem, quamuis difficile paterere me abs te diuelli, rei tamen fructum considerans tibi ipsi iniuriam inferre maluisti, quo ista mea profectione mihi prospectum iri sentires. Quis igitur ingratitudinem meam non arguat? Quisue non increpet iure, si quantulumcunque id sit, quod inde hauserim, tibi non imputem primum? qui mihi et parentis fueris loco, Munusque in me omne, quod amicissimus quisque solet, liberalissime contuleris. Itaque inter caetera gratitudinis meae monumenta et istud etiam qualecumque sit libelli, amice beneficentissime, acceperis. Non quidem quod id professione tua istaque aetate dignum existimem, Sed ut eo obseruantiae meae in te debitum declarem. Qui ne uulgaria quidem ista emittere soleam, quin ea nominis tui argumento ueluti impresso, imprimis exornem. Tanto fortasse diuturniora futura, quanto uirtutes tuae immortalibus tituli, aeuum sibi longius despondeant. Vale.

\section{Letter 4}

It must have been during his stay in Italy that Augustinus established contact with a Venetian celebrity of the age, the highly cultured woman scholar Fedele Cassandra (1465-1558). Letter 4 is a letter of thanks addressed to Cassandra, in which Augustinus evokes the (public) speech ("...luculenta et exuberanti oratione tua...") that Cassandra had given praising him. ${ }^{16}$ Augustinus uses nice words to extol Cassandra's education, familiarity with sciences and compares her to the cultured and virtuous ladies of the antique world,

16 "AVG. Mora. CASSANdrae Fideli Venetae, Virgini pudicissimae. S.", fol. [Ciii $\left.{ }^{\mathrm{v}}\right]-\left[\mathrm{Ciiii}^{\mathrm{r}}\right.$ ] 
expressing his gratitude towards Cassandra for her laudation. The letter does not reveal on what occasion and forum Cassandra spoke about Augustinus.

At the time De modo epistolandi was published, Augustinus was already a doctor of canon law and artes. In the title of the 1492 prognosticon (Venice, after 13 November 1491, GW 3059), it says after his name “...Augustini bemi Olomucensis artium doctoris...", while in the dedication to the Johannes Blanchinus-issue (Venice, 1495, GW 4410), we find "Augustinuus [!] Morauus Olomucensis Jurispon. atque artium doctor...", and in the dedication letter to De modo epistolandi, there is the title "...Augustini Moraui Olomucensis decretorum atque Artium liberalium doctoris...".

The letter to Cassandra is undated. It is perhaps conceivable that the educated lady held the oration on the occasion of a special event during Augustinus's university years at Padua. We know that Cassandra had made a public speech as early as 1487 on the occasion of a baccalaureate graduation in Padua. However, we do not know of any speech that she may have made in front of or in favour of Augustinus Moravus. The only collection of Cassandra's letters and speeches, printed in 1636, does not feature Augustinus Moravus's name. Nevertheless, it is likely that the oration Augustinus's letter must have responded to was related to Augustinus's university (doctoral) promotion. ${ }^{17}$

AVG. Mora. CASSANdrae Fideli Venetae, Virgini pudicissimae. S. (fol [Ciii $\left.\left.{ }^{\mathrm{v}}-\mathrm{Ciiii}{ }^{\mathrm{r}}\right]\right)$

INgratus omnino iudicandus sim, Cassandra pudicissima, si luculenta et exuberanti oratione tua exornatus memorem me tui non praestiterim. Cumque singulorum passim praeconiis celebreris, aliquid etiam ad cumulum non adiecerim. Quamuis quod mihi ingenium? Quae litteratura? Quod exquisitus orationis filum? quod tantis tuis dotibus huic excultae ac omnium disciplinarum genere referte eloquentiae satisfacere se posse confidat? ut non ante concidat sub onere, quam uel aliquotam eius partem non dico adaequet, sed ne digne attingat quidem. Quid enim orationis tuae redundantiam, leporem suauitatemque commemoro? nonne id diuina quadam in te uirtute relucet totius te philosophiae peritia usque adeo emersisse, ut in abditissima quaeque philosophorum sensa uiuaci ingenio tuo penetraueris, Non dialectices argutias, non poeticae uaria abstrusaque inuolucra praeterieris, quin tam praesenti in singula oratione descendas, tamquam cuilibet rei nata, eaque enutrita uiderere, hinc tot de te

17 Cassandrae Fidelis Venetae epistolae et orationes, edited by Giacomo Filippo Tomasini (Padova: Francesco Bolzetta, 1636). For Cassandra Fedele, see most recently: Cassandra Fedele, Letters and Orations, edited by Diana Robin (Chicago: The University of Chicago Press, 2000); Farkas Gábor Kiss, "Franciscus Pescennius Niger Báthory Miklós váci püspök udvarában és a Scholasticum Orosianae iuventutis dramma [Franciscus Pescennius Niger in the court of Vác bishop Miklós Báthory and Orosianae iuventutis dramma]," Magyar Könyvszemle 129 (2013), 265-281. 
doctissimorum uirorum praeconia, hinc ad aedes tuas tanquam ad peculiare aliquod uirtutum studiorumque sacellum quotidiana conciliabula uisuntur, nec est quisquam ex omni iuuentute ueneta, qui se tuo contubernio doctiorem euasisse non iactet. Cessent igitur, cessent inquam, quae uel de Corinna, Hortensia, Carixena Praxillaque iactantur, quae singulari aliquo studiorum genere effloruerunt. Nos Cassandram nostram in omni disciplinarum alea, omni cum antiquitate conferemus. Illae citra notam prostratae pudicitiae non fuerunt, haec uel Sulpitiam uel Claudiam pudicitia et integritate anteierit. ${ }^{18}$ Sed nimis fortasse et quam epistolaris ratio permittit, Cassandra facundissima, euagamur, dum animi nostri erga te uirtutem testificatam tibi efficere adnitimur: Institueram id quidem mox, ut abs te digressus patauium redieram: Verum contentiones meae litterariae hoc mihi in te studium aliquantisper inuidere. Vnde cum aliquantula intermissio studiis nostris intercessit, id modo de me ad summam cognoueris uelim eum me esse, qui fide, animi uirtute te mirifice obseruem tibique quantulumcunque in me sit ingenii et uirium, ob incredibilem uirtutem tuam deferam, quo me proprio quodam iure uti possis. Vale, aetatis nostrae delicium.

\section{Letter 5}

The letter Augustinus Moravus addressed to the renowned Bologna professor Filippo Beroaldo the Elder (1453-1505) is a useful reading also for philologists. ${ }^{19}$ In the first part, Augustinus congratulates Beroaldo on his commentaries to Propertius and heaps praise on Beroaldo for his highly useful explanations. Then Augustinus goes on to say that the text of another Roman author, Suetonius, also requires corrections and explanations; therefore he asks and encourages Beroaldo to issue another commentary to accompany Suetonius's corrupted text.

Thanks to Anna Rose's recent monograph, we have a good idea of Beroaldo's activity in publishing and commenting on Propertius's text. ${ }^{20}$ In possession of her findings, we can make a number of useful remarks concerning this practically unknown letter of Augustinus. ${ }^{21}$

Beroaldo's Propertius editions and commentary were repeatedly issued in the $15^{\text {th }}$ century $(1487,1491,1493,1500)$. Augustinus's letter addressed to Beroaldo came out in 1495 in De modo epistolandi (according to the colophon,

18 Augustinus Moravus compares Cassandra to the cultured and virtuous ladies of the antique world.

19 "AVG. Mora. Olom. Philippo Beroaldo Bononiensi. S. P.", fol. [Ciiiir ${ }^{\mathrm{r}}$.

20 Anna Rose, Filippo Beroaldo der Ältere und sein Beitrag zur Properz-Überlieferung (Beiträge zur Altertumskunde, Band 156), (München-Leipzig: K. G. Saur, 2001).

21 Augustinus's letter to Beroaldo is unknown to researchers highly familiar with Beroaldo's correspondence. I am grateful to Silvia Fabrizio-Costa and Mirko Menna for their private communication in answer to this question (September 2012). 
"Venetiis per Simonem beuilaqua Papiensem idibus ianuarii M. CCCC. XCV."). About the commentary, Augustinus says to Beroaldo "... what you compiled/edited over four years..." ("...quadriennium annum concinnaras..."). Thus, in fact, only the first three editions can be considered (Bologna, 1487; Venice, 1491; Venice, 1493).

According to the letter, the commentary to Propertius that Augustinus read was completed "magnifici Vdalrici Rosensis auspiciis." Beroaldo did not dedicate the first three Propertius editions $(1487,1491,1493)$ to the mentioned Udalricus Rosensis, but someone else; thus the word 'auspiciis' is not used in its standard meaning in the text. "Udalricus Rosensis" is the Latin name of Ulrich von Rosenberg (Udalricus/Uldricus Rosensis, Oldřich III. z Rožmberka, 1471-1512), who together with his brother Peter (Petr z Rožmberka, ?-1523) came from an old and famous noble family. They did their studies in Bologna. The older boy, Peter was friends with Bohuslav Hasištejnský z Lobkovic (Bohuslav Lobkowicz von Hassenstein). Beroaldo dedicated his 1488 Annotationes centum to the younger boy, Ulrich, praising the young Czech man's loyalty to the Catholic Church. Later too, Beroaldo kept in touch with the older man, Peter. A member of Filippo Beroaldo's family, Vincenzo Beroaldo the merchant often turned up in Bohemia. ${ }^{22}$

Ulrich was only 16 years old when he went to Bologna, and there is evidence that from 1487 he was living in Bologna. In the dedication of the mentioned 1488 Annotationes centum, Beroaldo calls him "puer." The most likely explanation is that Ulrich must have subsidized the Propertius edition, and this is what "auspiciis" may be referring to. ${ }^{23}$ In the second half of the letter, Augustinus refers to Beroaldo's lectures, examinations and explanation of Suetonius. He is encouraging Beroaldo to complete and publish them. Beroaldo's Suetonius-edition came out in Bologna on $5^{\text {th }}$ April 1493, but had been complete already in 1492. Therefore, if Beroaldo finished his Suetonius commentary in 1492, then the letter in which Augustinus "urges" it must be dated no later than 1492. This means that in the letter, Augustinus is talking about the Propertius commentary of 1487 or 1491, as in 1492 he cannot have referred to the 1493 Propertius commentary.

Anna Rose argues that the reference to the 1491 edition is the most likely solution. The 1491 edition was already an improved, more elaborate version, which was also circulated in a wider circle. According to Anna Rose, Ulrich's age is an argument against the earlier issue (1487), as the 16-year-old Czech was still too young to be able to actively contribute financial resources to an edition. ${ }^{24}$

22 Rose, Filippo Beroaldo..., 124-125; See also: Josef Truhlář, Humanismus a humanisté v Čechách za krále Vladislava II. (Rozpravy Č. Akademie Fr. Josefa, III. 3. 4.), (V Praze: Č. Akademie Fr. Josefa, 1894), 100-102, 104.

23 I am grateful to Anna Rose for her most helpful private communication (August 2013).

24 Rose, Filippo Beroaldo..., 124; as well as Anna Rose's private communication (August 2013). I also thank Gábor Bolonyai and Máté Ittzés for their private communication in helping me in dating the text (November 2013). 
Thus, Augustinus Moravus probably studied the second edition (1491), which was supported by Ulrich von Rosenberg, although it was not dedicated to him, and he may have been familiar with the first (1487) and when writing the letter probably this was the experience he had. In fact, Augustinus must have sent his undated letter to Beroaldo from Padua ("Ex Gymnasio patauino."). Signs of Augustinus's presence in Italy (more accurately, of his studies in Padua) start appearing from 1491-1492. The earlier mentioned prognosticon for 1492 was issued in Venice, probably still in 1491. At the end of the print, at the end of/below Augustinus's letter to Johannes Basilius, there is "Ex patauino Gymnasio Idibus nouembribus". Augustinus's letter to Johannes Lucilius Santritter, which can be read in the 1492 Venice edition of Tabulae astronomicae Alfonsi regis, originates from Padua in the summer of 1492 ("Ex Gymnasio Patauino...").

AVG. Mora. Olom. Philippo Beroaldo Bononiensi. S. P. (fol [Ciiiir $\left.{ }^{r-v}\right]$ )

MIraberis, scio, philippe[!] Beroalde, uir eruditissime et ad primum mox litterarum mearum conspectum dices. Quid sit, quod antehac tibi incognitus, familiaribus his tecum agere incipiam, moxque quem nullo mihi officio demerui, talibus de rebus consulere audeam, quae et non mediocrem operam exposcant, quaeque delio aliquo, ut dici solet, indigeant narratore. ${ }^{25}$ Verum quum consilii mei rationem non grauate admiseris, facile etiam non dubito patieris id officii abs te requiri, in quo non communem tantummodo causam suscipias, id est studiosorum, sed multorum usque in haec tempora errori et pertinatiae validius, uti assoles, relucteris atque occurras.

Sed quorsum ista, inquies, incideram nuper, uir eruditissime, in Propertianos illos commentarios tuos atque eas annotationes ${ }^{26}$, quas magnifici Vdalrici Rosensis auspiciis, quadriennium annum concinnaras, Eas pro mea consuetudine quum semel atque iterum expendissem, gratulari mox mihi ipsi cepi, et quidem uehementissime, eam me potissimum aetatem incidisse, in qua tanta iam optimorum ingeniorum copia redundaret, ut quae longa temporum negligentia obsoluerant, ad pristinum iterum candorem et maiestatem reuiuiscant.

Cui enim, ut alios taceam, non summae admirationi et stupori quodammodo existere debeat hominem quotidianis exercitationibus districtum, tot obiter difficillima enigmata, fetura vix dum menstrua absoluere ualuisse, tanta lectissimorum uerborum obseruantia tantoque et totiugo eruditissimorum scriptorum testimonio, ut non temere alicui tot et talia eo interuallo recensere, nedum inuenire eligereque potis sit.

25 'Delius narrator' $=$ Apollo

26 i.e. Propertianos commentarios 
Laudat Quin. in caesare[!] calorem, acumen, in Sulpicio memoriam, in Temistocle in Secundo elegantiam ${ }^{27}$, quis haec in Beroaldo nostro cumolatius[!] non admirabitur? hoc potissimum saeculo tam quam defecto et in quo rudis barbaries omne id, quicquid erat latini splendoris, iam pene occupauerit.

Visus es mihi tamen, ut ab[!] id, a quo paulo digressus sum reuertar, dum in aliis non segniter elaborasses, in Tranquillo scriptore grauissimo minus, quam res ipsa ferret, egisse, dum luculentissimam eius historiam, seu uitas dicere mauis, tot ubique mendis occupatam totque reconditis sensibus implicitam congnosceres.

At tumultuarius, inquit, is sermo erat et perinde, ut cuiuslibet loci in mentem uenerat, indistincta interpretatio, Scio id, uir eruditissime.

Atque ab eo liberius tete compellandi occasionem accipio, quum te scilicet uindicande romanae elocutionis alioquin et tanquam ex professo studiosissimum hoc tanquam officio desultorio iterum excitare contendam, maxime uero quod et ipse in hanc sententiam nullo impulsore, sed proprio, ut aiunt, marte descendas, unde et e re nostra immo studiosorum omnium feceris, Philippe Berualde[!], uir litteratissime, si id, quod sparsa recognoscendorum librorum industria maxima cum laude suscepisti, id nunc in unum etiam tranquillum conferas, eumque tot undique mendis occupatum uides, pristinae denuo luci integritatique restituas.

Scio, quid Calphurnius noster ${ }^{28}$ in eo enarrando nobis attulerit nuper, absque controuersia consumatissimus[!] et quem aetatis nostrae Varronem ${ }^{29}$ iure appellare possemus, non inutile tamen fuerit, Si illius et ipse rationibus, quod non dubito, accedens et in eandem causam quodammodo conspirans: Vanam et temerariam aliorum opinionem, impetu facto ualidius deuincas, quo nihil melius, nihil sanctius, nihil denique communi utilitati conducibilius effici potest. haec una omnium uota existimes, has singulorum contentiones, ut qui instituendae iuuentuti tantopere insudas, in hoc uno etiam studiosorum desideria non negligas. Vale, uir eruditissime. Ex Gymnasio patauino.

27 cf. Quintilianus, Institutio oratoria 10, 1, 114; 10, 1, 116; 11, 2, 50

28 Giovanni Calphurnio (1443-1503), Italian scholar and teacher

29 Marcus Terentius Varro (116 BC - 27 BC), ancient Roman scholar and writer 



\section{EDINA ZSUPÁN}

\section{Bessarion immer noch in Buda? Zur Geburt der Bibliotheca Corvina*}

Wegen des fragmentarischen Zustandes des erhaltenen Quellenmateriales aus dem Mittelalter ist es oft schwierig, den kulturellen Charakter gewisser Zeitalter in der ungarischen Kulturgeschichte genau zu bestimmen. Manchmal fehlen auch Quellen dafür, irgendeine - zwar anzunehmende - Kontinuität zwischen Formen, Verfahren und „kulturellen Gewohnheiten“, die in zeitlich zueinander naheliegenden Zeitaltern zu beobachten, ausreichend zu beweisen. Besonders gehört zu diesen „fraglichen“ Epochen auch die ungarische Frührenaissance und innerhalb derer auch die berühmte Periode der Regierung von König Matthias, zumindest was ihre Relationen sowohl zum vorangehenden als auch zum darauf folgenden Zeitalter betrifft. Genau wegen dieser Fragmentarität wird ein „Bruch“ in der Forschung der Matthias-Epoche und der Humanistenkultur unter Wladislaus dem II. und seinem Sohn, Ludwig dem II., das heißt in den Jagiello-Zeiten, spürbar. Dieser Bruch entspricht natürlich dem tatsächlichen kulturellen Bruch (oder viel mehr „Wechsel“), den der unerwartete Tod des großen Renaissance-Königs in der ungarischen höfischen Kultur verursachte. Nach dem Tod von Matthias verließen nämlich fast alle italienischen Humanisten, die das kulturelle Leben in Buda modernisierten, den königlichen Hof. Der Fall des Antonio Bonfini, der dennoch in Buda blieb und sein historisches Werk über die Geschichte Ungarns auch unter Wladislaus fortsetzte, war eine seltene Ausnahme. Statt der italienischen war jetzt eine stärkere böhmische Präsenz am Budaer Hof ${ }^{1}$ zu beobachten. Das bedeutete natürlich nicht, dass es in Ungarn keine italienischen Humanisten mehr gab (z.B. Francesco Negri, Girolamo Balbi, Celio Calcagnini und die Italiener im Kreise Ippolito d'Estes). Die italienische Anwesenheit verlor einfach an ihrer Funktionalität, galt nicht mehr als Muster für die Kultur des übrigen Landes.

Selbstverständlich gab es trotzdem eine Kontinuität zwischen den beiden darauffolgenden Epochen, also zwischen dem ungarischen Humanismus bzw. der Elitenkultur im 15. Jh. und der Bildung am Anfang des 16. Jh.s. Die

\footnotetext{
* Für das Lektorieren des deutschen Textes bin ich Monika Szeder-Niemann zu Dank verpflichtet.

1 Z. B. Jan Šlechta ze Všehrd, Augustinus Moravus Olomucensis, Johannes Schellenberg, Bohuslav Hasištejnský z Lobkovic.
} 
Früchte, die aus der vorangegangenen Epoche hervorgegangen waren, die Anwesenheit der italienischen Humanisten am ungarischen Hof, die Meister und Künstler, verschwanden nicht spurlos, sondern beeinflussten in Wesentlichen weitere kulturelle Bereiche für Jahrzehnte. Die Forscher der JagielloZeiten zeigten jüngst mit Erfolg diese Kontinuität auf, die wohl besser bei den schönen Künsten ${ }^{2}$ als, wegen des erwähnten Quellenmangels, in der Welt der litterae zu beweisen sind.

Was den ungarischen Humanismus angeht, ist die Kontinuität ebenfalls zweifelsfrei. Dem intensiven italienischen Einfluss, die in der ungarischen Elitenkultur seit dem Anjou-Zeitalter ununterbrochen stark war, haben die Jahrzehnte der Matthias-Regierung einfach ein neues Gesicht gegeben und auch der Tod des großen Königs konnte nicht jenen von ihm unabhängigen, unsichtbar verlaufenden Vorgängen ein Ende machen, die die Errungenschaften des italienischen Humanismus in der ungarischen Hochkultur präsent gemacht haben.

Die Kulturvermittlerrolle der königlichen Bibliothek, die nach Matthias' Tod noch Jahrzehnte im Palast prunkte, braucht nicht eigens geschildert zu werden. Als Augustinus Moravus Olomucensis, Mitglied der tschechischen Kanzlei von Wladislaus dem II., Anfang des 16. Jh.s in Buda den ehemaligen Codex des Kardinals Bessarion aus dem Regal der erwähnten Bibliothek nahm und ihn Sebastian Murrho zum Herausgeben empfahl, wählte er so einen Band, aus dem sich im 15. Jh. ein bedeutendes Kapitel der Buchkultur in Ungarn entfalten konnte und dessen inhaltliche und Beziehungsbezüge auch die spätere königliche Buchproduktion wesentlich beeinflusste und dessen Relevanz schließlich auch am Anfang des 16. Jh.s immer noch gültig war.

Seine Wahl lässt nämlich auch darauf schließen, dass Augustinus gewisse Werke von Bessarion kannte. Seine Wahl soll also nicht zufällig gewesen sein. Das wird auch von der Bemerkung Sebastian Murrhos im Vorwort der Ausgabe von 1513 bewiesen: Quam variae, quamque reconditae doctrinae fuerit Bessa-

2 In anderen Bereichen der Kultur, z. B. in dem der Kunst, ist die Situation günstiger, aber genau wegen des Quellenmangels ist die Kontinuität in der Bildung und in den geistigen Orientierungen und Präferenzen schwieriger zu beweisen. S. hauptsächlich die Arbeiten von Árpád Mikó (unter anderem z. B.): „Via Hungarica: Az itáliai reneszánsz az Alpokon túl: olasz művészek a Jagelló-kori Magyarországon,“ in "Ez világ, mint egy kert..." Tanulmányok Galavics Géza tiszteletére, hrsg. Bubryák Orsolya (Budapest: MTA Müvészettörténeti Kutatóintézet Gondolat Kiadó, 2010), 355-366; Idem, A reneszánsz Magyarországon (Budapest: Corvina Kiadó, 2009); „'Gótika és barokk között. A reneszánsz múvészet problémái a kora újkori Magyarországon," in Mátyás király öröksége I-II.: Késő reneszánsz müvészet Magyarországon (16-17. század). Kiállítás a Magyar Nemzeti Galériában. 2008. március 28-2008. július 27., hrsg. Mikó Árpád, Verő Mária (A Magyar Nemzeti Galéria kiadványai 2008/3-4.), (Budapest: Magyar Nemzeti Galéria, 2008), 22-35; Idem, „Reneszánsz, magyar reneszánsz, magyarországi reneszánsz: Részletek egy stíluskorszak kutatásának történetéből,“ in Mátyás király öröksége 2008, 115-146; Idem, „Italienische Künstler in Ofen/Buda zur Zeit der Jagiellonen,“ in Maria von Ungarn (1505-1558): Eine Renaissancefürstin, hrsg. Martina Fuchs, Orsolya Réthelyi (Geschichte in der Epoche Karls V., 8.), (Münster: Aschendorff Verlag, 2007), 347-362. 
rion, Constantinopolitanus Patriarcha, neminem latere arbitror, qui libros eius in calumniatorem Platonis legerit... Bessarions Hauptwerk ist also im mitteleuropäischen Humanismus Anfang des 16. Jh.s eine allgemein bekannte Lektüre gewesen. Augustinus Moravus hat aller Wahrscheinlichkeit nach im Besitz dieser Kenntnisse den Bessarion-Codex der Budaer Bibliothek zur Herausgabe vorgeschlagen.

Im Nachfolgenden wird in Zusammenhang mit "dem Fall“ des BessarionCodex geschildert, welche Wirkung die Kontakte zu Bessarion auf die ungarische höfische Buchkultur um die Mitte und in der zweiten Hälfte des 15. Jh.s ausübten, und mit der Hilfe von kodikologischen und paläographischen Untersuchungen wird eine solche Codexgruppe innerhalb des Bestandes der königlichen Bibliothek nachgewiesen, deren meiste Stücke gerade dank Bessarions Beziehungsnetzwerk entstanden sind und in einem gewissen Sinne die Basis des Corvinenbestandes der achtziger Jahre bildeten. Die Lektüre dieser Werke war auch zu Beginn des 16. Jh.s oft eine wichtige Kulturelle Komponente.

Ein eigenes Buch Bessarions in Buda: Budapest, OSZK, Cod. Lat. 438.

Dank der Initiative von Augustinus Moravus Olomucensis wurden zwei Werke des Kardinals Bessarion im Jahre 1513 in Strassburg veröffentlicht. ${ }^{3}$ Das eine ist ein Traktat unter dem Titel De sacramento eucharistiae (ca. 1464), das andere ist der berühmte Brief des Kardinals an die Griechen, die Epistola ad Graecos, unter seinem Originaltitel die Encyclica ad Graecos, die er nach seiner Ernennung zum lateinischen Patriarchen von Konstantinopel im Mai 1463 in Viterbo verfasst hatte. Aus dem Kolophon der Ausgabe erfährt man, dass die beiden Werke entweder von Augustinus Moravus selbst oder auf seine Anregung von irgendjemand anderem aus einer Handschrift der Budaer Bibliothek abgeschrieben wurden. ${ }^{4}$ Diese Handschrift, eine authentische Corvine, ist erhalten geblieben und wird heute in der Széchényi Nationalbibliothek (OSZK) aufbewahrt. ${ }^{5}$ (Abb. 1)

3 Cardinalis Bessarion, Quae in sequentibus habentur ... Oratio de sacramento eucharistiae. Epistola ad Graecos, ed. Augustinus Moravus (Argentorati: ex aedibus Schurerii, Men. Decembr. 1513).

4 „Ex libro syncerae fidei transcripta, qui in Bibliotheca Budensi, Pannoniae inferioris habetur, Cura Augustini Moravi, viri doctissimi."

5 Budapest, Országos Széchényi Könyvtár, Cod. Lat. 438. Zur kodikologischen Beschreibung der Handschrift s.: Emma Bartoniek, Codices Latini Medii Aevi (Budapestini, 1940), Nr. 438, S. 393-394; ferner Csaba Csapodi, The Corvinian Library. History and Stock (Budapest: Akadémiai Kiadó, 1973), S. 160, Nr. 115; jüngst s. die Beschreibung des Codex von Dániel Pócs in Mattia Corvino e Firenze. Arte e umanesimo alla corte del re di Ungheria, a cura di Péter Farbaky, Dániel Pócs, Magnolia Scudieri, Lia Brunori, Enikő Spekner, András Végh (Firenze: Giunti, 2013), Nr. 23, S. 108-109. 
Der Codex enthält eigentlich drei Werke von Bessarion. Den erwähnten beiden Werken geht eine um 1449 verfasste Schrift unter dem Titel De ea parte evangelii ubi scribitur si eum volo manere, quid ad te voran, in dem der Kardinal eine Stelle des Johannes-Evangeliums kommentiert und die Notwendigkeit der Verwendung einer textkritischen Methode auch beim Text der Vulgata betont.

Die auf ihrer Titelseite mit bianchi girari verzierte Pergamenthandschrift wurde nach 1464 in Italien angefertigt. Einen besonderen Wert verleiht der Handschrift die Tatsache, dass unter dem Wappen des Königs Matthias in der Mitte der unteren Bordüre das Wappen von Bessarion, ein doppeltes goldenes Kreuz mit Kardinalhut vor rotem Grund, zu finden ist. Das heißt, das Buch gehörte einst zum Buchbestand des Kardinals, was die Annahme suggeriert, dass die im Codex befindlichen Texte der enthaltenen drei Werke relativ korrekt sein dürften. Die Anfertigung der Abschrift und die Korrektur der Texte wurden aller Wahrscheinlichkeit nach selbst in Bessarions Kreis ausgeführt. Dafür spricht auch die Person des Schreibers, Leonardus Iob, der ein familiaris Bessarions war. Auf unbekannte Weise gelangte die Handschrift später in die Budaer königliche Bibliothek, wo sie mit dem Wappen des Königs und einem typisch corvinischen vergoldeten Ledereinband versehen und dadurch in den repräsentativen Bestand der königlichen Bibliothek eingegliedert wurde.

In ihrem Aufsatz hat die erste Beschreiberin der Handschrift, die Historikerin Emma Bartoniek, schon bemerkt, dass fast alle Autoren, die von Bessarion in seinem Werk über die Eucharistie erwähnt werden - so Johannes Damascenus, Gregorius Nazianzenus, Chrysostomus, Basilius Magnus -, interessanterweise auch in dem erhaltenen Bestand der Bibliotheca Corvina auffindbar sind. ${ }^{6}$ Die darauf folgende Forschung hat das Warum im Wesentlichen schon beantwortet. Zwei hervorragende Persönlichkeiten der ungarischen Literaturwissenschaft haben diese Problematik von zwei verschiedenen Seiten her beleuchtet. Ihre Konklusionen führten zum Schluß in beiden Fällen zur Person des Kardinals Bessarion. Einerseits betonte der Altphilologe József Huszti die Bedeutung der italienischen neuplatonischen Bewegung hinsichtlich der inhaltlichen Zusammenstellung der Budaer königlichen Bibliothek. ${ }^{7}$ Andererseits deutete der Literaturhistoriker Tibor Klaniczay darauf hin, wie grundlegend die allgemeine geistige und politische Mobilisierung gegen die Osmanen den Charakter des ungarischen Frühhumanismus bestimmt haben. ${ }^{8}$ Im Brennpunkt beider Bestrebungen stand Kardinal Bessarion.

Ebenfalls war es Tibor Klaniczay, der in seinem Werk über die Vorgeschichte der akademischen Bewegung in Ungarn auch die kulturellen Aspek-

6 Bartoniek Emma, „A Magyar Nemzeti Múzeum Országos Széchényi Könyvtárának BessarionCorvinája“, in Magyar Könyvszemle LXI (1937), 120-125, hier S. 121.

7 Huszti József, Platonista törekvések Mátyás király udvarában (Minerva Könyvtár I), (Pécs, 1925).

8 Klaniczay Tibor, „A kereszteshad eszméje és a Mátyás-mítosz,“ in Irodalomtörténeti Közlemények 79 (1975), 1-14. 
te der Kontakte zwischen Bessarions Kreis in Rom und der ungarischen Elite aufgedeckt und auf die Ähnlichkeiten zwischen dem Charakter vom Contubernium des Erzbischofes Johannes Vitéz de Zredna und dem vom Bessarions Kreis hingedeutet hat, da die Leitprinzipien beider Gelehrten-Gesellschaften das wahre Glaubensleben und die Kultivierung der edelsten Wissenschaften waren. ${ }^{9}$

\section{Kontakte zwischen Bessarions und Johannes Vitéz's Kreisen}

Abgesehen von den geringen verfügbaren Quellen sollten die erhaltenen Bücher dazu dienen, das Netz der komplizierten kulturellen Verbindungen ein bisschen besser zu beleuchten. Die Anwesenheit unserer Bessarion-Handschrift in der Bibliothek von König Matthias wird natürlich aufgrund der oben erwähnten Kontakte erklärbar. Es ist aber nicht einfach, den Inhalt dieser groben Feststellung zu verfeinern.

Die im Codex enthaltenen drei Werke wurden von Bessarion ursprünglich in Griechisch verfasst. Ihre lateinischen Versionen sind Ergebnisse einer Kampagne, initiiert von Bessarion selbst um die Mitte der sechziger Jahre, in deren Rahmen der Kardinal versucht hat, sich in einen lateinischen Autor zu transformieren und seine eigenen Werke - hauptsächlich die über die Kirchenunion - persönlich ins Lateinische zu übersetzen. Der Kardinal stellte eine Auswahl aus diesen Übersetzungen in einer bestimmten Reihenfolge zusammen und widmete sie Papst Paul dem II. Wie Dan Joan Mureşan es jüngst darstellte, vertritt die Budapester Bessarion-Corvine einen Teil der erwähnten Auswahl. ${ }^{10}$ Dafür spricht auch die Reihenfolge der drei Werke in unserer Handschrift, die mit der Reihenfolge im entsprechenden Teil der dem Papst gewidmeten Sammlung identisch ist. Dank der Forschungen des John Monfasani ist bekannt, dass der Kardinal genau in diesen Jahren auch an der lateinischen Übersetzung seines Hauptwerkes In Calumniatorem Platonis arbeitete. Neben Niccolo Perotti half auch der Dominikaner Theologe Giovanni Gatti dem Kardinal bei der Umarbeitung und verfasste eine Ergänzung scholastischen Inhalts zu Bessarions Argumentation. Laut der Forschungen von Monfasani soll aber Giovanni Gatti in Ungarn an einem Traktat für Bessarions

9 Klaniczay Tibor, A magyarországi akadémiai mozgalom előtörténete (Budapest: Balassi, 1993); Földesi Ferenc, „,A Society of Scholars and Books. The Library of János Vitéz," in A Star in the Raven's Shadow. János Vitéz and the Beginnings of Humanism in Hungary. Exhibition organised by the National Széchényi Library 14th March - 15th June 2008, ed. Ferenc Földesi (Budapest: OSZK, 2008), 88-100.

10 Dan Ioan Muresan, „Bessarion et l'Église de rite Byzantin du royaume de Hongrie (14631472)," in Matthias Corvinus und seine Zeit. Europa am Übergang vom Mittelalter zur Neuzeit zwischen Wien und Konstantinopel, hrsg. Christian Gastgeber, Ekaterini Mitsiou, Ioan-Aurel Pop, Mihailo Popović, Johannes Preiser-Kapeller, Alexandru Simon (Wien: Verlag der ÖAW, 2011), 77-92. 
Werk gearbeitet haben, sein Präsenz ist nämlich zu dieser Zeit in der Umgebung des Erzbischofes Johannes Vitéz de Zredna nachweisbar. Später wurde er Professor der Universitas Istropolitana in Pressburg (Pozsony). ${ }^{11}$

Gattis Anwesenheit in Ungarn ist emblematisch hinsichtlich dessen, wie eng die Verbindungen zwischen Bessarions Kreis und Vitéz's Umfeld zu dieser Zeit gewesen sein müssen. In diesem Kontext muss unbedingt auch Johannes Regiomontanus erwähnt werden, der gerade aus Rom, aus Bessarions Kreis, nach Buda kam und dort der erste Kanzler der Universitas Istropolitana und Hofastronom des Königs Matthias wurde. ${ }^{12}$ Man darf auch nicht Andreas Hess, den ersten Drucker in Ungarn, übergehen, der wohl auf Berufung des Johannes Vitéz ebenfalls aus Bessarions Kreis nach Ungarn gekommen war. ${ }^{13}$ Vitéz konnte sich also aus erster Hand über die literarische Produktion in Bessarions Umfeld informieren. Ein kurzer Satz, eingetragen vom Erzbischof auf die letzte Seite seines Exemplars von Trapezuntius's Comparatio Platonis und Aristotelis, macht eindeutig, dass ihm auch Bessarions Gegenschrift, die In Calumniatorem Platonis, völlig bekannt war. Vitéz schreibt folgendermaßen: Contra hunc scripsit Bessarion cardinalis Nicenus, vir eruditissimus, pro Platone non tamen contra Aristotelem. ${ }^{14}$ Wie gesagt, Bessarion versuchte seine ins Lateinische übersetzten Werke bewusst vertreiben zu lassen. Dieser Kampagne ist auch die Anwesenheit der Bessarion-Corvine in Ungarn zu danken.

Die wahre Kontaktperson in Ungarn war zu dieser Zeit also der gelehrte Erzbischof von Esztergom, Johannes Vitéz. Es ist schwer zu entscheiden, ob Bessarions Schenkung, die Handschrift mit seinen Werken, für den König selbst oder für Vitéz bestimmt war. Diese Frage bezieht sich eigentlich ebenfalls auf die Anfänge der Corvinischen Bibliothek im Allgemeinen und kann nicht durch die einfache Lösung der Konfiskation der Bibliothek des Johannes Vitéz nach dessen Tod beantwortet werden. Es sieht so aus, dass die oben dargestellten literarischen Kontakte, die Bücher, einen wesentlichen Einfluss auf die nachfolgende inhaltliche Zusammenstellung der königlichen Bibliothek ausgeübt, oder - besser gesagt - die Anfänge der Bibliothek wesentlich bestimmt haben. In diesem Zusammenhang sollen auch die Werke von Geor-

11 John Monfasani, „A Tale of Two Books: Bessarion's In Calumniatorem Platonis and Georg of Trebizond's Comparatio Philosophorum Platonis et Aristotelis," Renaissance Studies 22 (2008), 1-15; A Star in the Raven's Shadow 2008 (wie Anm. 9), Nr. 29, S. 166 (F. Földesi, E. Zsupán); John Monfasani, „Cardinal Bessarion's Own Translation of the In Calumniatorem Platonis," Accademia XIV (2012), 7-21. Ich möchte Herrn Péter Ekler meinen herzlichen Dank dafür aussprechen, dass er mir den Aufsatz zur Verfügung gestellt hat.

12 Ernst Zinner, Leben und Wirken des Joh. Müller von Königsberg genannt Regiomontanus. Zweite vom Verfasser verbesserte und erweiterte Auflage (Osnabrück: Otto Zeller, 1968), 245 f.

13 Borsa Gedeon, „Vitéz János és a könyvnyomtatás, “ Magyar Könyvszemle 107 (1991), 113-116; Idem, Andreas Hess (A Magyar Könyvszemle és a MOKKA-R Egyesület füzetei 6), (Budapest: Argumentum Kiadó - OSZK - MTA BTK ITI - MOKKA-R Egyes., 2013).

14 Rom, BAV, Vat. Palat. Lat. 3382, vgl. A Star in the Raven's Shadow 2008 (wie Anm. 9), Nr. 29, S. 166 (F. Földesi, E. Zsupán). 
gius Trapezuntius, die er König Matthias widmete, erwähnt werden. Trapezuntius war nämlich bis zum Jahr 1451, bis zur Verfeindung der beiden, ebenfalls ein festes Mitglied Bessarions famiglia. ${ }^{15}$

\section{Widerspiegelung der Kontakte zu Bessarion im Bestand der Bibliotheca Corvina}

Die Anfänge der Budaer königlichen Bibliothek sind nicht geklärt. Überhaupt ist die Periodisierung der dreißigjährigen Geschichte der Sammlung wegen des Datenmangels sehr schwierig. Trotzdem wurde schon von der früheren Forschung festgestellt, dass irgendein engerer Zusammenhang zwischen der Bibliothek des berühmten Erzbischof-Bibliophilen, Johannes Vitéz, und der Bibliotheca Corvina bestanden haben soll. ${ }^{16}$ Dieser Zusammenhang ist in der Tat auf mehreren Ebenen zu beobachten.

Was seine inhaltliche Komponente betrifft, zeichnet sich ein Handschriftenkreis innerhalb des Corvinenbestandes aus, der seine Existenz wohl genau den erwähnten Verbindungen zu Bessarions Kreis sowie der befruchtenden Vermittlung von Johannes Vitéz und der Tätigkeit um die Gründung der Universität in Pozsony verdanken kann.

Unter den Corvinen-Codices befinden sich nämlich Handschriften, derer Abschriften wohl in den sechziger Jahren des 15. Jh.s, in Vitéz's Umgebung (teilweise vielleicht in Zusammenhang mit der Tätigkeit um die Universität herum?) angefertigt wurden. Dabei sind Hände mehrerer Schreiber nachweisbar, darunter vielleicht auch einige von Italienern. Ihre Produkte sind einfachere Handschriften, geschrieben in humanistischer Buchschrift, immer auf ein gröberes (offensichtlich nicht italienisches) Pergament. Inhaltlich sind diese meistens rhetorische und astronomische Werke antiker oder zeitgenössischer Autoren. Die Titelseiten sind einfach gehalten: oben befindet sich meist eine bescheidene Inzipitformel in Rot, dann beginnt sofort der Text. Abgesehen vom Rand ist offensichtlich kein Platz für eine prächtigere Illumination reserviert.

Es sieht so aus, als ob es ein gemeinsames Charakteristikum dieser Handschriften sei, dass sie nach der Anfertigung ihrer Schrift für eine längere Zeit unilluminiert geblieben waren und ihre Illumination und endgültige Form

$15 \mathrm{Zu}$ ihm s. John Monfasani, George of Trebizond. A Biography and a Study of his Rhetoric and Logic (Leiden, 1976). Zu den Werken des Trapezuntius in der Corvinischen Bibliothek siehe jüngst die Aufsätze von Péter Ekler, vor allem „Propugnacula Christianitatis - studia humanitatis. Relations between Byzantium and Byzantine Humanists Active in Italy and Hungary in the Middle of the 15th Century", in A Star in the Raven's Shadow 2008 (wie Anm. 9), S. 105-116.

16 Zur Bibliothek von Vitéz s. Klára Csapodi-Gárdonyi, Die Bibliothek des Johannes Vitéz (Studia Humanitatis 6), (Budapest: Akadémiai Kiadó, 1984); Földesi Ferenc, „A Society of Scholars and Books. The Library of János Vitéz," in A Star in the Raven's Shadow 2008 (wie Anm. 9). 


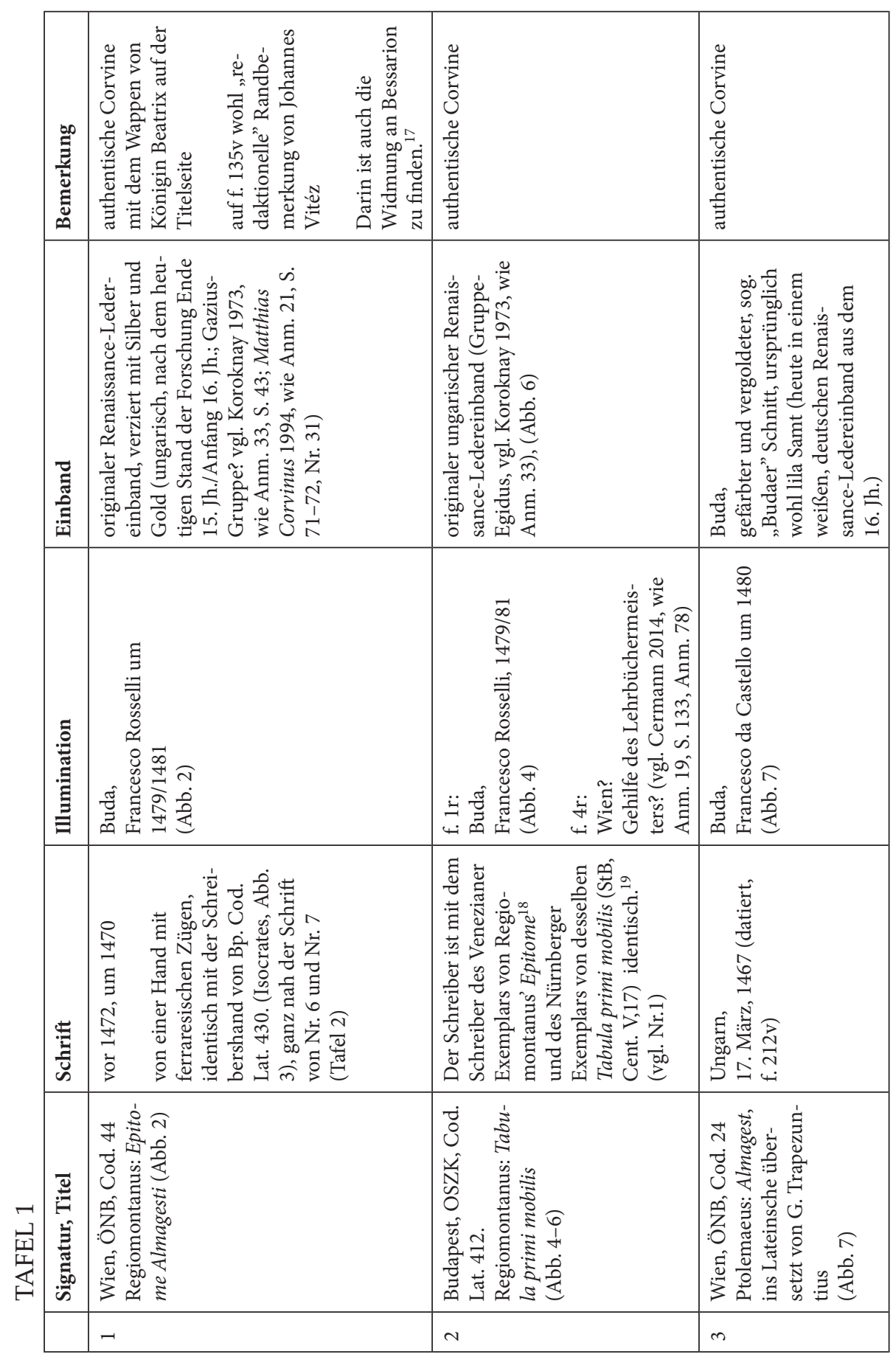




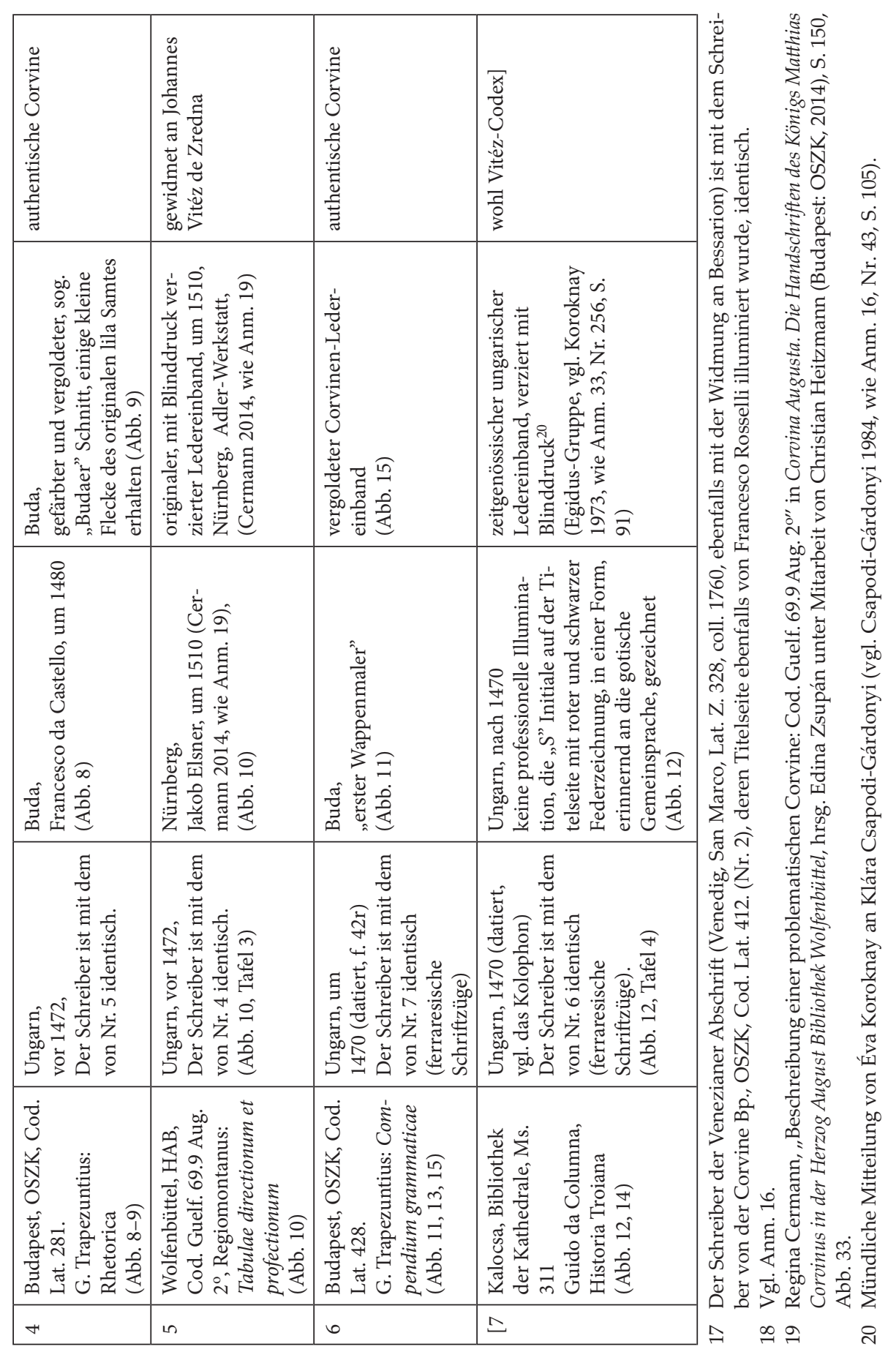


erst um 1480 bekommen haben. Diese Handschriften stehen wohl in einem engen Zusammenhang mit der (Neu)herrichtung der Budaer königlichen Bibliothek um das Jahr 1480.

Im Nachfolgenden werden sechs charakteristische Beispiele aus dieser Gruppe herausgehoben und eingehender präsentiert. Unter anderem ist es interessant zu beobachten, in welche abwechslungsreichen Weisen die darzustellenden Codices ihre späteren Illuminationen erhalten haben und dadurch fast die ganze Palette von Möglichkeiten der Budaer Werkstatt um 1480 spiegeln.

Die Beschreibungen konzentrieren sich vor allem auf die Entstehungsgeschichte der Einzelcodices und versuchen das Verhältnis zwischen der Entstehungszeit der Abschrift und der der Illumination zu beleuchten.

\section{Die Wiener Regiomontanus-Handschrift (Wien, ÖNB, Cod. 44) ${ }^{21}(A b b .2)$}

Das enthaltene Werk ist die Epitoma in Almagestum von Regiomontanus. Mit der Aufgabe des Epitoma wurde der Lehrer von Regiomontanus, der Wiener Professor Georg Peuerbach noch von Bessarion selbst beauftragt, als der Kardinal als Gesandter in Wien war. Peuerbach aber verstarb kurz danach und gab den Auftrag an seinen Schüler Regimontanus weiter. Letzterer führte diese Aufgabe noch bei Bessarion in Rom aus - wohl am Ende des Jahres 1462 -, und machte sich unter anderem mit diesem Werk in seinem Gepäck, das er Kardinal Bessarion gewidmet hatte, auf den Weg nach Buda. ${ }^{22}$

Die Abschrift entstand aller Wahrscheinlichkeit nach in Ungarn. Das Schriftbild weist ferraresische Züge auf. ${ }^{23}$ Von derselben Hand stammt auch eine andere Corvine (Budapest, OSZK, Cod. Lat. 430., Isocrates, Abb.

21 Hermann Julius Hermann, Die Handschriften und Inkunabeln der italienischen Renaissance, 3 (Beschreibendes Verzeichnis der illuminierten Handschriften in Österreich, Neue Folge, Band VI), (Leipzig: Verlag von Karl W. Hiersemann, 1932), Nr. 73, S. 85f.; Csapodi 1973, wie Anm. 5, S. 344, Nr. 572.; Matthias Corvinus und die Bildung der Renaissance, Handschriften aus der Bibliothek und dem Umkreis des Matthias Corvinus aus dem Bestand der ÖNB, Katalog einer Ausstellung der Handschriften- und Inkunabelsammlung der ÖNB, 27. Mai - 26. Oktober 1994, hrsg. Ernst Gamillscheg, Brigitte Mersich, mit Beiträgen von Otto Mazal (Wien: ÖNB, 1994), S. 71-72, Nr. 31. (Volldigitalisat zugänglich: www.onb.ac.at)

22 Zinner 1968, wie Anm. 12, S. 80-81.

23 Ein wichtiger Beweis für die Tätigkeit einiger Schreiber in Ungarn, die eine durch ferraresische Züge geprägte Schriftart verwendeten, ist eine auf das Jahr 1465 datierte Handschrift (Augsburg, Staats- und Stadtbibliothek $2^{\circ}$ Cod. 107, Claudius Ptolemaeus, Cosmographia in der Übersetzung des Jacobus Angelus de Scarperia), geschrieben in einer schönen, durch ferraresische Züge geprägten humanistischen Buchschrift. Das Kolophon der Handschrift lautet folgendermaßen: Claudii ptolemei viri alexandrini cosmographie octavus et ultimus liber explicit per quendam Hungarum: 1465: (f. 91r). Sie wurde also von einem in Ungarn tätigen Schreiber abgeschrieben. Allerdings wurde der Codex vom Lehrbüchermeister in Wien illuminiert, der viel für ungarischen Kunden arbeitete. Vgl. Pfändtner 2011, wie Anm. 31, S. 12, 14, 16, 18, 142, 182, Kat. Nr. 3. (S. 72), Abb. 98, 239. Ich bin Regina Cermann besonders dankbar, dass sie mich auf diese Handschrift aufmerksam gemacht hat. 
3, Tafel 2), derer Illumination und Einband ebenfalls am Budaer Hof hergestellt wurde und deren Miniator ebenfalls der sog. "erste Wappenmaler" war, wie es bei einer dritten Corvine mit der Grammatica von Trapezuntius (vgl. Tafel 1, Nr. 6, Abb. 11) - datiert auf das Jahr 1470 (f. 42r, Abb. 12) feststellbar ist. Ferner sind die Schreiberhände des letztgenannten Codex (Trapezuntius) und der Wiener Regiomontanus-Corvine einander sehr ähnlich. Es handelt sich wohl um zwei in der Umgebung des königlichen oder des erzbischöflichen Hofes in Esztergom tätige Schreiber, die entweder selbst in Italien (Ferrara?) geschult wurden oder diese Schriftart einfach nachahmten.

Ein Präzisieren der Datierung der Handschrift wird dank der Bemerkung auf f. 135v möglich. Am oberen Rand ist nämlich folgende Warnung in roter Tinte zu lesen:

Ista addit(i)o p(er)tinet sup(ra) i(n) lib(ro) sexto ad signum tale*

Zahlreiche paläographische Eigenschaften der Schrift lassen uns annehmen, dass der Eintrag von der Hand des Johannes Vitéz stammt: die Größe des unter den kursiven Buchstaben verwendeten, aber nicht kursiven "s" (über den Mittelband verlängert), die für Vitéz so charakteristische Gestaltung des "g" (mit einem unten links geöffneten und geknickten Bogen), der Federzug und der Schwung der waagerechten Zickzacklinie sowie die Dicke und der Winkel des am Ende nach rechts oben ragenden Haarstriches bei der Abkürzung des „supra“, die Platzierung des „o“ bei der Abkürzung des „libro“" die Dichte der Schrift im Allgemeinen, der Abstand der einzelnen Wörter voneinander, die Neigung zur Verwendung der Abkürzungen (und deren für Vitéz charakteristische Proportion), die Breite der drei Buchstabenbereiche, usw. ${ }^{24}$ Für Vitéz spricht natürlich auch der Inhalt der Bemerkung: der Erzbischof hat nämlich Handschriften nicht zuletzt mit dem Ziel durchgelesen, sich um ihren Text zu kümmern, ihn zu korrigieren und „in Ordnung zu bringen". Wenn unsere Hypothese richtig ist und der Einträger in der Tat Vitéz war, datiert der Eintrag die Entstehung der Abschrift unbedingt vor das Jahr 1472.

Die Buchmalerei wurde jedoch zur Handschrift aller Wahrscheinlichkeit nach viel später zugegeben. Es ist schon lange bekannt, welch entscheidende Rolle das Ankommen der Königin Beatrix in Ungarn im Jahre 1476 im kulturellen Leben des Budaer Hofes gespielt hat. Damals wurde auch die Bibliothek neu konzipiert und eine Werkstatt am Hof für Buchherstellung eingerichtet. Im Jahr 1478 schrieb Matthias nach Nürnberg, um sich nach dem Nachlass des verstorbenen Regiomontanus, seines früheren Hofastronomen, zu erkundigen. Genau zu dieser Zeit kamen Illuminatoren aus Italien nach Buda. Namentlich kennen wir Francesco da Castello aus Mailand -

24 Der am besten verwendbare Vergleichscodex zur Hand von Vitéz: Budapest, OSZK, Cod. Lat. 370. Im Codex stammen alle Randbemerkungen (meistens in roter, aber auch in schwarzer Tinte) von seiner Hand. (Volltext zugänglich: www.corvina.oszk.hu) 
er blieb hier für mehrere Jahre und ist zur wichtigsten Persönlichkeit (und vielleicht zum Leiter) der Budaer Werkstatt für Buchherstellung geworden - sowie Francesco Rosselli aus Florenz. Rosselli hielt sich nachweisbar zwischen 1479 und 1481 in Buda auf. ${ }^{25}$ Die Illumination dieser Handschrift ist ein Werk Francesco Rossellis, die der Florentiner Meister irgendwann im angegebenen Zeitraum, während seines Budaer Aufenthalts, offensichtlich für die Königin angefertigte. (Ihr Wappen und ihr Porträt sind auf der Titelseite zu sehen.)

Im Zusammenhang mit dem Codex kann man auch auf weitere interessante Verflechtungen zwischen Inhalt und Buchproduktion hinweisen. Ein anderes handschriftliches Exemplar des vorliegenden Werkes, also der Almagest-Epitome von Regiomontanus, ist erhalten und wird heute in Venedig aufbewahrt (Venedig, San Marco, Lat. Z. 328, coll. 1760). Auch das venezianische Exemplar enthält die Widmung an Bessarion. ${ }^{26}$ Das Interessanteste an der Handschrift - hinsichtlich unseres Hauptgesichtspunktes - ist, dass der Schreiber dieses Codex dieselbe Person war, wie der Schreiber unseres nächsten Beispiels, der Budapester Regiomontanus-Corvine (Cod. Lat. 412.).

Zusammenfassend kann gesagt werden, dass die Wiener Regiomontanus-Corvine aller Wahrscheinlichkeit nach in zwei Phasen entstanden ist. Die Abschrift war wohl schon vor dem Jahr 1472 fertig und entstand in der Umgebung von Vitéz und Regiomontanus selbst. Die Illumination wurde jedoch ungefähr zehn Jahre später, um das Jahr 1480, nach der Ankunft von Königin Beatrix und der Herrichtung der Budaer Werkstatt, von dem damals in Buda tätigen Florentiner Miniator Francesco Rosselli hinzugefügt.

25 Zum Budaer Aufenthalt Rossellis s. jüngst: Dániel Pócs, „Urbino, Florence, Buda. Models and Parallels in the Development of the Royal Library," in Matthias Corvinus, the King. Tradition and Renewal in the Hungarian Royal Court (1458-1490), exhibition catalogue, Budapest History Museum 19 March 2008 - 30 June 2008, ed. Péter Farbaky, Enikő Spekner, Katalin Szende, András Végh (Budapest: Budapest History Museum, 2008), 146-163. Zu Francesco da Castello s. Anm. 37.

26 Eine Reproduktion der Titelseite wird publiziert: Zinner 1968, wie Anm. 12, Abb. 32, Tafel 14. 


\section{TAFEL 2}

Siquidem maiorel mirucl ab bis que iam muenta exant tcadendiC

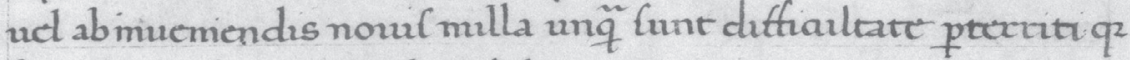
fegt magno femper Atudio claborauexe: ut poltexitatem nontam aureo atq: oprbs qurutute \& borns axtibs veddént loapletem. Non dum enm ambiaio \&c actece aupiditate hormu mgenia mficé

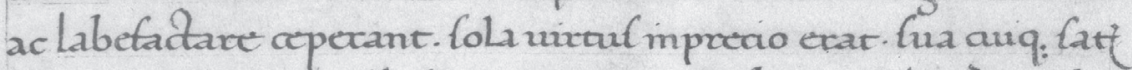
placebant. mullus sccinfcars honoz quecebatux vbi uo paula em auprdo henda mortalum anmms vecepfit. detlueve bon af $a^{2}$

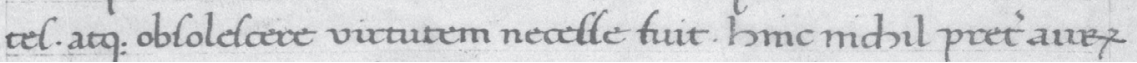

Wien, ÖNB, Cod. 44, f. 1r (Detail) = Nr. 1, Abb. 2

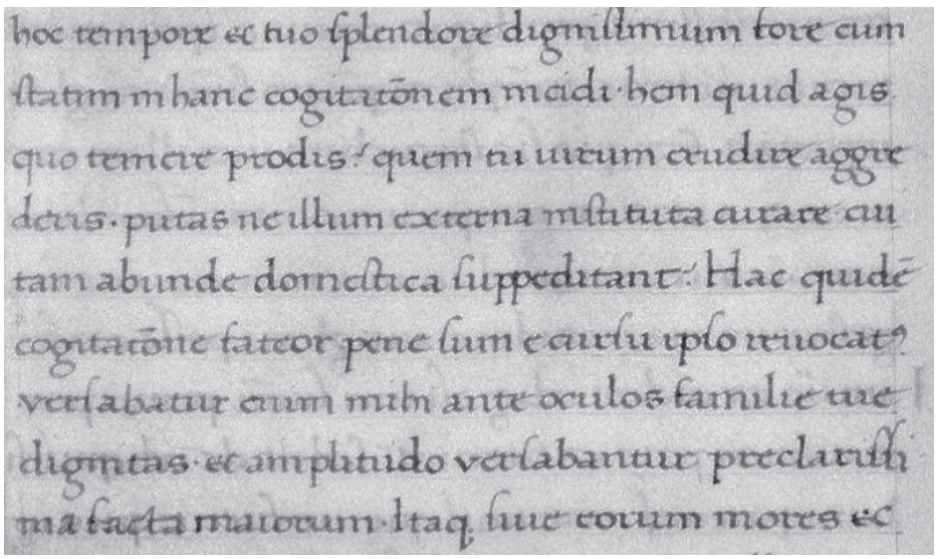

Budapest, OSZK, Cod. Lat. 430., f. 1r (Detail) = Abb. 3

tace allurdendo uertatem upuf rex frgutati comenta? quibufdam fietioniouf teanfumplexunt. ut nö uea que foup ferunt undecentur audientibuf p forip fiffe fod pozuaffabulofa intex quof fuif dicbuf maxme aucto xtatif bomed. aput grecof euid yforie puxam ex fm

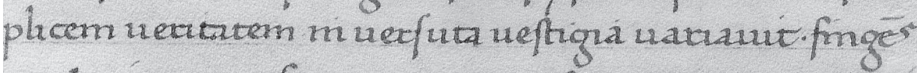
multa que non fuocunt. ecque fuecunt alutex tein" formando. fntwoduxut emm deof quof colurit anaq gentuliar mpugnaffe troyan of ex cum cif fuffe utt

Kalocsa, Bibliothek der Kathedrale, Ms. 311, f. 1r (Detail) = Nr. 7, Abb. 14 


\section{Die Budapester Regiomontanus-Corvine (OSZK, Cod. Lat. 412.)27}

Dieser Codex enthält ein anderes Werk von Regiomontanus, die Canones LXIII in tabulam primi mobilis mit einer Widmung an König Matthias. ${ }^{28}$ Laut der Behauptung des großen Kenners von Regiomontanus' Leben, Ernst Zinner, hat der Astronom dieses Werk noch in Italien begonnen - die Idee des Werkes ist nämlich ebenfalls in Bessarions Umgebung geboren -, es aber erst in Ungarn beendet und Matthias Corvinus gewidmet. ${ }^{29}$ Offensichtlich entstand auch dieser Codex in mehreren Phasen: die Abschrift des Haupttextes könnte irgendwann um das Jahr 1470 in Ungarn angefertigt worden sein. Von der Schreiberhand des Codex stammt nämlich nicht nur das venezianische Exemplar von Regiomontanus' Almagest-Epitome mit der Widmung an Bessarion (Venedig, San Marco, Lat. Z. 328, coll. 1760, s. oben), sondern auch das heute in Nürnberg befindliche Exemplar der Tabula primi mobilis (StB Cent. V,17), das wohl ein persönliches Exemplar des Regiomontanus gewesen sein könnte, der im Jahr 1471 von Ungarn nach Nürnberg umgezogen ist. ${ }^{30}$

Die endgültige Gestaltung des Codex ließ jedoch bis zum Aufenthalt von Francesco Rosselli in Ungarn in den Jahren 1479/81 auf sich warten. Die Titelseite, also die erste Seite der Widmung an König Matthias (f. 1r) wurde nämlich von dem Florentiner Künstler in seinem schönen Florentiner Renaissance-Stil illuminiert (Abb. 4). Dagegen vertritt der Miniaturenschmuck der inneren, das Hauptwerk einleitenden,Titelseite den Stil der mitteleuropäischen und vor allem den der Wiener gotischen Buchmalerei (f. 3r) ${ }^{31}$ (Abb. 5). Das Endergebnis ist eine interessante Legierung geworden, ein schönes Beispiel des sog. Budaer Mischstieles, mit dem Unterschied zu den späteren Werken, dass die verschiedenen Stilelemente sich hierbei noch nicht innerhalb einer Seite miteinander mischen.

Der Codex hat einen zeitgenössischen, ungarischen Renaissance-Ledereinband, der den Typ vertritt, der bei den Büchern aus der Bibliothek von Jo-

27 Hermann 1932, wie Anm. 21, Nr. 71, S. 78-79; Bartoniek 1940, wie Anm. 5, S. 376, Nr. 412; Csapodi 1973, wie Anm. 5, S. 343, Nr. 568. A Star in the Raven's Shadow 2008, wie Anm. 9, Nr. 49, S. 234-237 (F. Földesi) und Cermann 2014, wie Anm. 19.

28 Klára Csapodi-Gárdonyi kennt neben der Budapester Corvine vier weitere Exemplare dieses Werkes: Wien, ÖNB, Cod. 5292, von f. 95r an; Florenz, Biblioteca Nazionale, B. II. III. 3. (enthält ebenfalls die Widmung an König Matthias); Besançon, Bibliothèque Municipale, Ms. 481; Roma, BAV, Vat. Palat. Lat. 1439, ff. 13-39. Vgl. Csapodi-Gárdonyi 1984, wie Anm. 16, Nr. 90, S. 132.

29 Zinner 1968, wie Anm. 12, S. 154, Abb. 35.

30 Cermann 2014, wie Anm. 19, S. 150, Abb. 3.

31 Die Illumination von f. 3r könnte vielleicht dem Lehrbüchermeister (oder einem Gehilfen des Lehrbüchermeisters, vgl. Cermann 2014, wie Anm. 19, S. 133, Anm. 78) zugeschrieben werden. Zum Lehrbüchermeister jüngst s. Karl-Georg Pfändtner, Die Handschriften des Lehrbüchermeisters (Codices Manuscripti , Supplementum 4, März 2011), (Purkersdorf: Verlag Brüder Hollinek, 2011). 
hannes Vitéz öfter verwendet wurde. ${ }^{32}$ (Abb. 6) Hinsichtlich der Entstehungsgeschichte des Codex wirft dieser Einband weitere Fragen auf. Für den Bestand der königlichen Bibliothek wurde nämlich wohl um 1480 - wie es unten detailliert geschildert wird - ein eigener Einbandtyp (oder Einbandtypen?) entwickelt. Der vorliegende Einband gehört jedoch nicht zu ihnen, sondern vertritt eine andere Einbandart, die der sog. Egidus-Gruppe. Laut der Forschungen von Éva Koroknay erschienen die zur Gruppe gehörenden Einbände um das Jahr 1470 und wurden wohl im Budaer Dominikanerkloster hergestellt. ${ }^{33}$ Aber nach der Titelseite (f. 1r) urteilend war dieser Codex - zumindest in seiner endgültigen Form - für den König bestimmt. Deswegen ist es merkwürdig, dass er keinen in der königlichen Bibliothek verwendeten Einband erhalten hatte. Dafür kann eine mögliche Erklärung sein, dass der Codex zu dem Zeitpunkt schon eingebunden war (und sogar in seinem heutigen Einband), als seine erste Titelseite (f. 1r), die sich an König Matthias richtete, endgültig ausgearbeitet wurde. Es ist also vorstellbar, dass sofort nach dem Abschreiben um das Jahr 1470 der ganze Codex fertig gestellt war (mitsamt der gotischen Illumination auf der Titelseite /f. 3r/ und dem Einband). Als nach der Ankunft von Francesco Rosselli und im Rahmen der Bibliotheksentwicklung - bei der die Werke von Regiomontanus eine große Rolle gespielt haben - die Entscheidung getroffen wurde, den Codex für den König und die königliche Bibliothek „umzugestalten“ ${ }^{34}$, schrieb derselbe Schreiber, der ca. 10 Jahre zuvor auch an dem Haupttext gearbeitet hatte, auf die unbeschriebenen Vorsatzblätter ${ }^{35}$ der Handschrift die an Matthias gerichtete Widmung ein und der neuangekommene Florentiner Meister illuminierte sie.

Für diese Annahme spricht, dass der Zustand und die Farbe der Tinte in der Matthias-Widmung sich von der des Haupttextes völlig unterscheiden und auch der Gesamteindruck der Schrift anders ist (starrer, gezeichneter), obwohl die beiden Textteile zweifellos von derselben Hand stammen. Ferner

32 Einige Parallelen innerhalb der Vitéz-Bibliothek z. B.: Wien, ÖNB, Cod. 100 Lucanus, Pharsalia (vgl. A Star in the Raven's Shadow 2008, wie Anm. 9, Nr. 20, S. 138-141); G. Peuerbach, Theoricae novae planetarum, Krakau, Biblioteca Jagiellonska, Ms. 599 (vgl. Koroknay 1973, wie Anm. 33, S. 93, Nr. 263); Kalocsa, Bibliothek der Kathedrale, Ms. 311 (vgl. Koroknay 1973, wie Anm. 33, S. 91, Nr. 256). Einen Einband von ähnlichem Typ hat auch das Krakauer Exemplar von Regiomontanus' Werk, Tabulae directionum, das das eigene Exemplar des anderen bedeutenden Hofastronomen von König Matthias, Martyn Bylica war (Krakau, BJ, Cod. 597, zu einer Reproduktion des Einbandes s. Cermann 2014, wie Anm. 19, S. 146, Abb. 15).

33 Sz. Koroknay Éva, Magyar reneszánsz könyvkötések (Müvészettörténeti Füzetek 6), (Budapest: Akadémiai Kiadó, 1973), S. 39.

34 Es steht im Einklang mit der Absicht Matthias', die Werke von Regiomontanus im Budaer Palast sammeln zu lassen. Dafür wendete sich der König brieflich Ende 1478 auch an die Nürnberger (s. oben).

35 Bei den in Ungarn, in der Umgebung vom königlichen Hof hergestellten Handschriften, sind mehrere unbeschrieben gelassene Seiten/Vorsatzblätter nicht beispiellos. Z. B. Wolfenbüttel, HAB, Cod. Guelf. 84.1 Aug. 2; Wien, ÖNB, Cod. 44 (Nr. 1); Budapest, OSZK, Cod. Lat. 430.; Budapest, OSZK, Cod. Lat. 281. 
scheint der Text der Widmung nicht im Codexkörper integriert gewesen zu sein, im Sinne, dass der Haupttext nicht sofort nach der Widmung anfängt, sondern erst auf der darauf folgenden Seite. Die Widmung endet ganz oben auf f. 2 v und nach den Endzeilen bleibt ein breites, unbeschriebenes Pergamentfeld.

Zusammenfassend also kann auch bei der Budapester RegiomontanusCorvine nachgewiesen werden, dass dieser Codex zur Gruppe der Handschriften gehört, deren endgültige Form in mehreren Etappen erreicht wurde und die nach einer außercorvinischen Vorgeschichte eine neue Rolle in der königlichen Bibliothek und der Herrscherrepräsentation von König Matthias bekommen hat. Bei dem vorliegenden Beispiel handelt es sich wohl um einen schon um 1470 beendeten, fertigen, eingebundenen Codex, dessen innere Titelseite (f. 3r) in einem einheimischen, gotischen Stil gemalt wurde, der aber 10 Jahre später, um das Jahr 1480, im Rahmen der Bibliothekskampagne von König Matthias durch die von demselben Schreiber eingeschriebene MatthiasWidmung und die von Francesco Rosselli hinzugefügte Renaissance-Illumination ein neues, "Corvinisches" Gesicht bekommen hatte.

\section{Die Wiener Ptolemaios-Corvine (ÖNB, Cod. 24) $)^{36}(A b b .7)$}

Der Codex enthält das Almagest von Ptolemaios in der Übersetzung von Georgius Trapezuntius.

Ihr Text ist datiert, im Kolophon ist das Datum 17. März $1467 \mathrm{zu}$ lesen (f. $212 v$ ). Unter dem Kolophon befindet sich ein Horoskop, das die Konstellation der Sterne am Gründungstag der Universitas Istropolitana, am 5. Juni 1467 demonstriert. Die Abschrift war also schon im Jahr 1467 fertig, aber die Illumination wurde erst viel später, um 1480, von dem Mailander Francesco da Castello hinzugefügt.

Der Beginn des Ungarn-Aufenthalts des erwähnten Miniators um das Jahr 1480 ist durch einige von ihm illuminierte datierte Wappenbriefe zu beweisen. Die Budaer königliche Buchproduktion wurde in den darauf folgenden Jahren (oder in gewissem Sinne sogar Jahrzehnten) im Wesentlichen durch seinen Stil geprägt. ${ }^{37}$ Die Wiener Ptolemaios-Corvine kann für eines der charakteristischsten und bedeutendsten Werke von Francesco da Castello erachtet werden.

36 Hermann Julius Hermann, Die Handschriften und Inkunabeln der italienischen Renaissance 4 (Beschreibendes Verzeichnis der illuminierten Handschriften in Österreich, Neue Folge, Band VI), (Leipzig: Verlag von Karl W. Hiersemann, 1933), Nr. 48, S. 120-125; Csapodi 1973, wie Anm. 5, S. 338, Nr. 558.; Zinner 1968, wie Anm. 12, S. 145f.; Matthias Corvinus 1994, wie Anm. 21, Nr. 30, S. 70-71.

37 Zur komplizierten Problematik der Budaer Werkstatt s. jüngst eingehend und umfassend, mit der ganzen früheren Literatur: Árpád Mikó, „,Über den Miniator der Wolfenbütteler Tolhopff-Corvine," in Corvina Augusta 2014, wie Anm. 19, S. 223-255. 
Der Codex erscheint auch im Zusammenhang mit den offenen Fragen der Bibliotheca Corvina als besonders wichtig. Obwohl er heute in einem weißen, mit Blinddruck verzierten, deutschen Renaissance-Ledereinband aus dem 16. Jh. eingebunden ist, lässt sein buntgemalter und vergoldeter, sog. „Budaer" Schnitt uns vermuten, dass sein originaler Einband lila Samt gewesen sein könnte. ${ }^{38}$

Eine der offenen Fragen der Corvinenforschung ist nämlich, wann die charakteristischen, in Buda hergestellten, mit einem gemalten-vergoldeten Schnitt als ständiger Komponente versehenen, in ihrer Mehrzahl lilafarbigen, manchmal roten Samteinbände während der Geschichte der königlichen Bibliothek auftauchten. Die Wiener Ptolemaios-Corvine, derer Illumination eindeutig um $1480 \mathrm{zu}$ datieren ist, lässt darauf schließen, dass diese einheitliche Einbandart ebenfalls um 1480 im Rahmen der Neukonzipierung der Budaer königlichen Bibliothek und der Neuorganisierung der Werkstatt für Buchherstellung erstmals erschien. ${ }^{39}$

Beim vorliegenden Codex ist also eindeutig auf die zwei verschiedenen Herstellungsphasen hinzuweisen: die auf das Jahr 1467 datierte Abschrift wurde mit einer prächtigen Illumination erst um das Jahr 1480 versehen und durch diese für den König ausgestaltete Illumination in die königliche Bibliothek integriert.

4. Die Budapester Trapezuntius-Corvine (Rhetorica, OSZK, Cod. Lat. 281.) ${ }^{40}$ (Abb. 8)

Dieser Codex gilt - unter mehreren Aspekten sogar - als eine der nächsten Parallelen zur letzten Corvine. Das enthaltene Werk, die Rhetorik von Trapezuntius, ist eine der bedeutendsten humanistischen Zusammenfassungen der klassischen rhetorischen Tradition. Die auf ein gröberes, also nicht italienisches Pergament geschriebene Abschrift entstand wohl ebenfalls um das Ende der 60er Jahre des 15. Jh.s. Zu ihrer Datierung bietet die nächste Handschrift, der wohl vor 1472 datierbare Wolfenbütteler Regiomontanus-Codex (Cod. Guelf. 69.9 Aug. $2^{\circ}$ ), einen Anhaltspunkt (s. unten); der Schreiber beider Codices ist nämlich identisch. (Abb. 10 und Tafel 3)

Die Trapezuntius-Corvine - ähnlich wie die Wiener Ptolemaios-Corvine (ÖNB, Cod. 24) - wurde wieder ungefähr 10 Jahre später, um das Jahr 1480 von Francesco da Castello in der Budaer Werkstatt illuminiert. Der Codex erhielt einen lilafarbigen Samteinband (Abb. 9), und sein Schnitt wurde nach

38 Seine nächste Parallele innerhalb der jetzt untersuchten Gruppe ist die Trapezuntius-Corvine (Nr. 4).

39 Zur Problematik s. Edina Zsupán, „Zur Genese des Beatrix-Psalteriums, “ in Corvina Augusta 2014, wie Anm. 19, S. 179-211.

40 Bartoniek 1940, wie Anm. 5, S. 260-261, Nr. 281; Csapodi 1973, wie Anm. 5, S. 381-382, Nr. 672. 
der Budaer Art durch Färbung und Vergoldung ausgestaltet. ${ }^{41}$ Folgenderweise vermehrt auch diese Handschrift die Gruppe, deren Mitglieder um das Jahr 1470 für einen anderen Zweck abgeschrieben, aber erst 10 Jahre später, und zwar für die königliche Bibliothek und Repräsentation, profiliert und vollendet wurden.

5. Der Wolfenbütteler Regiomontanus-Codex (HAB, Cod. Guelf. 69.9 Aug. $\left.2^{\circ}\right)^{42}(A b b .10)$

Die Handschrift enthält das Werk Tabulae directionum et profectionum von Regiomontanus, das der berühmte Astronom während seines Ungarn-Aufenthaltes (1465-71), auf Johannes Vitéz's Bitte verfasst hat. Der Wolfenbütteler-Codex enthält auch das dem Johannes Vitéz gewidmete Vorwort.

Die Handschrift hat mehr als hundert Jahre hindurch Probleme in der Corvinenforschung verursacht, und zwar wegen des ungarischen königlichen Wappens auf der Titelseite, das dem bei den authentischen Corvinen meist verwendeten Wappenty ${ }^{43}$ besonders ähnelt. Von ihnen unterscheidet sich das Wappen im Wolfenbütteler-Codex einfach darin, dass es nicht das Wappen der Hunyadi Familie als Wappenfeld enthält. In den authentischen Corvinenhandschriften ist nämlich das Hunyadi-Wappen (schwarzer Rabe mit Goldring im Schnabel vor dunkelblauem Hintergrund) bei demselben Wappentyp charakteristisch immer im Herzschild platziert.

Wegen dieser Ähnlichkeit ist irgendwann gegen das Ende des 19. Jh.s, mit dem Beginn der modernen Corvinenforschung ${ }^{44}$, die Hypothese entstanden, dass dieser Codex angeblich eine Corvine gewesen sein könnte. Dagegen sprach aber die Tatsache, dass die Illumination der Handschrift als eine nürnbergische Arbeit bestimmt wurde, datierbar auf den Anfang des 16. Jh., also viel später als die Matthias' Zeit - genauso wie ihre Einband. Infolgedessen wurde die angebliche Corvine-Identität des Codex nicht beweisbar. Deshalb

41 Vom Originaleinband ist nur ein einziger Samtfleck und ein einziger, blattförmiger Schließbeschlag aus Messing erhalten. (http://www.corvina.oszk.hu/corvinas-html/hub1codlat281. htm)

42 Cermann 2014, wie Anm. 19.

43 1. Feld: altungarische Querbalken (abwechselnd rot und silber); 2. Feld: sich aufbäumender Löwe mit Doppelschwanz und Krone (silber vor rotem Hintergrund); 3. Feld: sich aufbäumender Löwe mit Doppelschwanz und Krone (silber vor rotem Hintergrund); 4. Feld: altungarische Querbalken (abwechselnd rot und silber); im Herzschild das Wappen der Familie Hunyadi: ein schwarzer Rabe mit Goldring im Schnabel vor dunkelblauem Hintergrund; über dem Wappen offene Krone. $\mathrm{Zu}$ den in den Corvinen befindlichen Wappentypen s. Csapodi 1973, wie Anm. 5, S. 490-496.

44 Die Handschrift ist schon im Jahre 1923 in der Corvinenliste von André de Hevesy zu finden; vgl. André de Hevesy, La bibliothèque du roi Matthias Corvin (Publicationes de la Sociétè française de reproductions de manuscrits à peintures 4), (Paris: Pour les membres de la société, 1923), Nr. 153, S. 83-84. 
fing die Forschung an diesem Punkt an, eine gegensätzliche Behauptung zu vertreten und dem Codex fast alle ungarischen Bezüge abzustreiten.

Zu einer gründlichen Analyse der Handschrift kam es im Jahr 2014, wobei Regina Cermann fast alle Fragen des Codex klärte. ${ }^{45}$ Als Beitrag zu dieser Analyse ist es mir gelungen zu beweisen, dass die Schreiberhand der Wolfenbütteler Handschrift auch in einer authentischen Corvine auftritt, und zwar in der Budapester Trapezuntius-Corvine (OSZK, Cod. Lat. 281.). Der Schreiber der beiden Handschriften war also identisch. (Abb. 8 und Tafel 3) Die Tatsache, dass die Trapezuntius-Corvine vollkommen in Ungarn hergestellt wurde, lässt darauf schließen, dass auch die Abschrift des Wolfenbütteler Regiomontanus-Codex in Ungarn entstanden ist. Übrigens ist unter den handschriftlichen Abschriften des Werkes das Wolfenbütteler Exemplar das einzige, das in einer humanistischen Buchschrift geschrieben wurde; es ist eigentlich das eleganteste Exemplar. Angesichts dessen, dass die Handschrift auch das dem Johannes Vitéz gewidmete Vorwort enthält, ist es auch nicht unvorstellbar, dass die Abschrift ursprünglich für seine Bibliothek bestimmt war.

Auf alle Fälle lässt das Vorhandensein des Vitéz-Vorwortes im Exemplar vermuten, dass die Abschrift wohl vor den Jahren 1471/72 entstanden war, also bevor der Erzbischof in König Matthias' Ungnade gefallen und gestorben ist.

Die Abschrift ist also wohl unilluminiert und ungebunden in Nürnberg angekommen. Ihr Possessor, Wilhelm (IV) Haller (1478-1534) ließ sie um 1510 durch den Nürnberger Meister, Jakob Elsner illuminieren und einbinden. ${ }^{46}$ Laut der Meinung von Regina Cermann hat Wilhelm (IV) Haller die ungarische, königliche ${ }^{47}$ Herkunft der Handschrift wohl gut gekannt und genau deswegen habe er das ungarische königliche Wappen auf ihre Titelseite hineinmalen lassen, vielleicht mit der Absicht, der Handschrift den wahren und ihr gebührenden Rang zurückzugeben.

Der Wolfenbütteler Regiomontanus-Codex ist also weder Ungarn, noch dem ungarischen Regierungszentrum abzusprechen. Er bereichert die Handschriftengruppe, deren Mitglieder - wie gesagt - gegen das Jahr 1470 wohl in der Umgebung von Johannes Vitéz entstanden. Der einzige Unterschied zu den parallelen Handschriften besteht darin, dass er seine spätere Illumination und seinen Einband nicht um 1480 in der Budaer Werkstatt, sondern um 1510 in Nürnberg erhalten hat.

45 Cermann 2014, wie Anm. 19.

$46 \mathrm{Zu}$ einer vollen Rekonstruktion der Geschichte der Handschrift s. die Beschreibung von Regina Cermann (Cermann 2014, wie Anm. 19).

47 In dieser Hinsicht hat der Umstand wohl keine Bedeutung, dass die Abschrift ursprünglich wahrscheinlich nicht für den König, sondern für Johannes Vitéz angefertigt wurde. Der spätere Nürnberger Besitzer wusste einfach, dass seine Handschrift irgendwann in der Umgebung des ungarischen Königs war. 


\section{TAFEL 3}

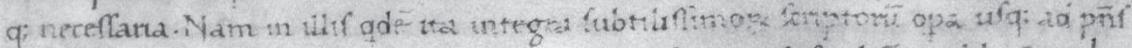

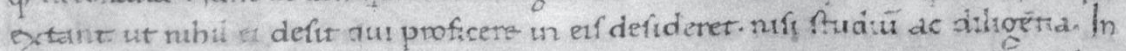

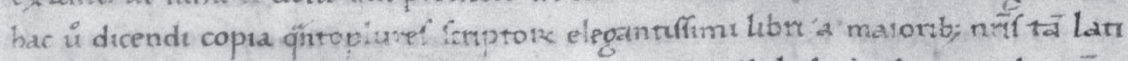

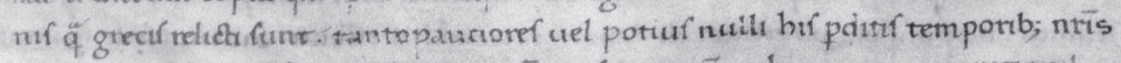
reperuntur. Quod fue negitgentsa oüun fue eoru $q$ docent. qux q otanonibus coviä pfitent" gnorantzao quadà aut pfidia fom fit unufqfó perfeipfu confideret.

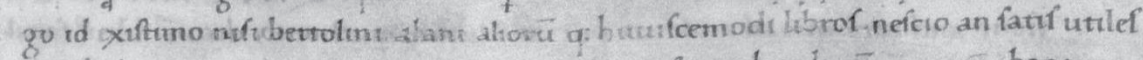

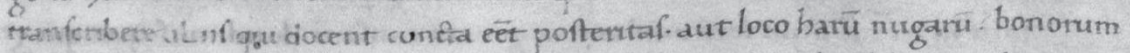

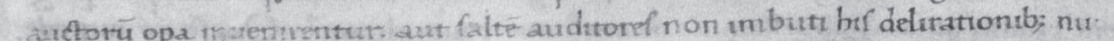
Budapest, OSZK, Cod. Lat. 281., f. 1r (Detail) = Nr. 4, Abb. 8

affidue felticet tuffioni ture morem getere:ac demum urdicto tuo non menut acuto qüreto dignü aliqgd reddere. Tua profecto monitroni nefaf ent conisa. uentre. qui entm licential in me babeat impertum preter te motsitf néo

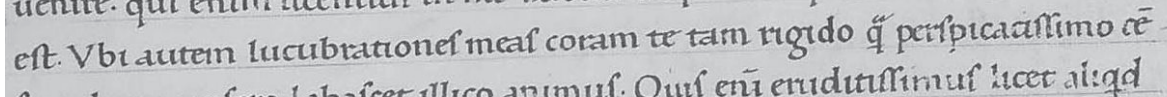

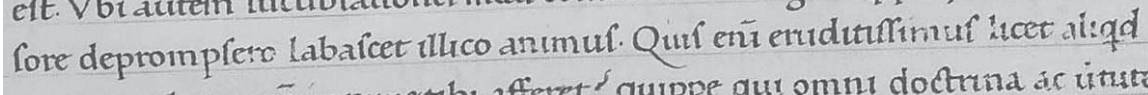
nouarum lutetari impunetibi afferet? quippe qui omni doctria ar rinste

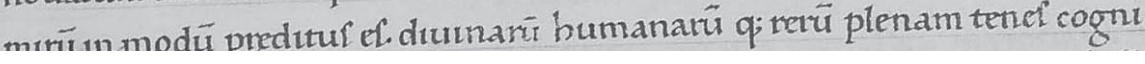
Wolfenbüttel, HAB, Cod. Guelf. 69.9 Aug. $2^{\circ}$, f. 1v (Detail) = Nr. 5, Abb. 10

\section{Die andere Budapester Trapezuntius-Corvine (Grammatica, OSZK, Cod.} Lat. 428. $)^{48}(A b b .11)$

Der ziemlich kleinformatige Codex enthält eine andere, im Schulunterricht gut benutzbare Arbeit des Byzantiner Humanisten Georgius Trapezuntius: das Compendium Grammaticae.

Der Schreiber war wieder ein Meister, der eine ferraresisch geprägte Schriftart anwendete und dessen anderes bekanntes, in Ungarn entstandenes Werk die Historia Troinana von Guido da Columna ist (vgl. Tafel 1, Nr. 7, Abb. 12, Tafel 4). Den letztgenannten Codex zählt die Forschung - Klára CsapodiGárdonyi folgend - zur Bibliothek von Johannes Vitéz de Zredna. ${ }^{49}$ Beide Co-

48 Hermann 1932, wie Anm. 21, Nr. 34, S. 42-43; Bartoniek 1940, wie Anm. 5, S. 385, Nr. 428; Csapodi 1973, wie Anm. 5, S. 379-380, Nr. 667.

49 Kalocsa, Bibliothek der Kathedrale, Ms. 311. Dafür spricht auch der Einband des Codex, vgl. Koroknay 1973, wie Anm. 33, S. 91, Nr. 256, Csapodi-Gárdonyi 1984, wie Anm.16, S. 105, Nr. 43. Klára Csapodi-Gárdonyi hat auch den Cod. Lat. 428. für einen Vitéz-Codex gehalten, und darin die Hand und das Signo "Jo" von Johannes Vitéz de Zredna entdeckt hat (ebenda). Ich stimme mit keiner der beiden Behauptungen überein. Die Randbemerkungen können 
dices sind datiert, und zwar beide auf das Jahr $1470 .{ }^{50}$ (Abb. 13, 14) (Eigentlich wird durch diese Datierung die circa auf das Jahr 1470 gelegte Datierungshypothese der Entstehung der ganzen, hier dargestellten Handschriftengruppe unterstützt.)

Während fast alle unsere bisherigen Beispiele, die unilluminiert wartenden Handschriften, von den auch namentlich bekannten italienischen Meistern der Budaer Werkstatt Francesco da Castello und Francesco Rosselli miniiert wurden, hat diese Arbeit der sog. „erster Wappenmaler“51, ein kleinerer Meister derselben Werkstatt, in die Hand genommen. Er hat die Titelseite mit einer bescheidenen Illumination und einem Matthias-Wappen versehen. Der Codex erhielt dann einen vergoldeten Corvine-Ledereinband. (Abb. 15)

Der Umstand, dass die Abschrift der Trapezuntius' Grammatica ebenfalls zu demselben, hier dargestellten Handschriftenfond gehörte wie die anderen unbeendet gebliebenen Abschriften, von denen die meisten in der Budaer Werkstatt ca. 10 Jahre später, um das Jahr 1480, ihre Illumination und Einband erhalten haben, lässt uns vermuten, dass auch diese Handschrift ihre Miniatur und ihren Corvineneinband ungefähr zu dieser Zeit, also um 1480, im Rahmen der erwähnten Bibliotheksentwicklung bekam. Dafür spricht auch ein anderes Beispiel, die Isocrates-Corvine (Budapest, OSZK, Cod. Lat. 430., Abb. 3), die wegen ihres Inhaltes kein unmittelbarer Teil unserer BessarionThematik ist, aber - was ihre Entstehungsgeschichte und Schreiberhand betrifft - ohne Zweifel zur hier betrachteten Gruppe gehört. Ihr Schreiber war nämlich mit dem unseres ersten Beispiels, der Wiener Regiomontanus-Corvine (ÖNB, Cod. 44, vgl. Nr. 1, Tafel 2), identisch, also entstand ihre Abschrift wohl um das Jahr 1470, und sie hat dieselbe Illumination (von der Hand des „ersten Wappenmalers") und denselben vergoldeten Corvinen-Ledereinband wie die Trapezuntius-Corvine. Dies lässt vermuten, dass sie zu derselben Zeit vollendet wurden, wie auch die anderen Mitglieder der Gruppe, also um 1480 .

nicht von der Hand von Vitéz stammen und das Zeichen, interpretiert als Signo "Jo“", können viel mehr als Abkürzung des Ausdrucks „et cetera“ erklärt werden. Zum Guido de Columna-Codex s. noch A Star in the Raven's Shadow 2008, wie Anm. 9, Nr. 22, S. 148-149 (F. Földesi).

50 Am Ende des Cod. Lat. 428. wurde das Datum nicht von dem Schreiber, sondern von einer anderen zeitgenössischen Hand in kursiver Humanistenschrift eingetragen.

51 Zu den sog. Wappenmalern s.: Hoffmann Edith, Wehli Tünde, Régi magyar bibliofilek, Zweite, erweiterte Ausgabe, hrsg. Wehli Tünde (Budapest: MTA Müvészettörténeti Kutatóintézet, 21992, 11929), 73-103; Mikó Árpád, „Bibliotheca Corvina - Bibliotheca Augusta,“ in Pannonia regia. Müvészet a Dunántúlon, 1000-1541, hrsg. Mikó Árpád, Takács Imre (Budapest: MNG, 1994), 402-406; Árpád Mikó, József Hapák, The Corvinas of King Matthias in the National Széchényi Library (Budapest: Kossuth Kiadó-OSZK, 2009), 76-96. 
TAFEL 4

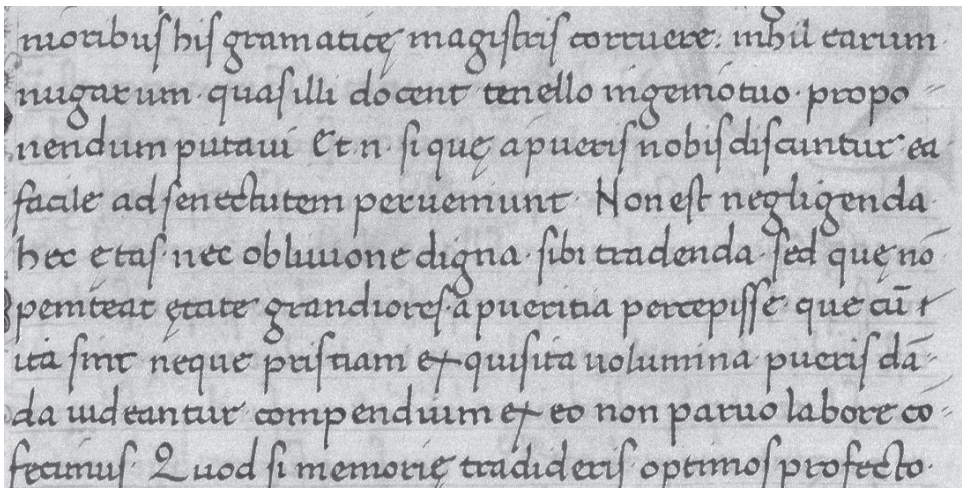

Budapest, OSZK, Cod. Lat. 428., f. 1r (Detail) = Nr. 6, Abb. 11

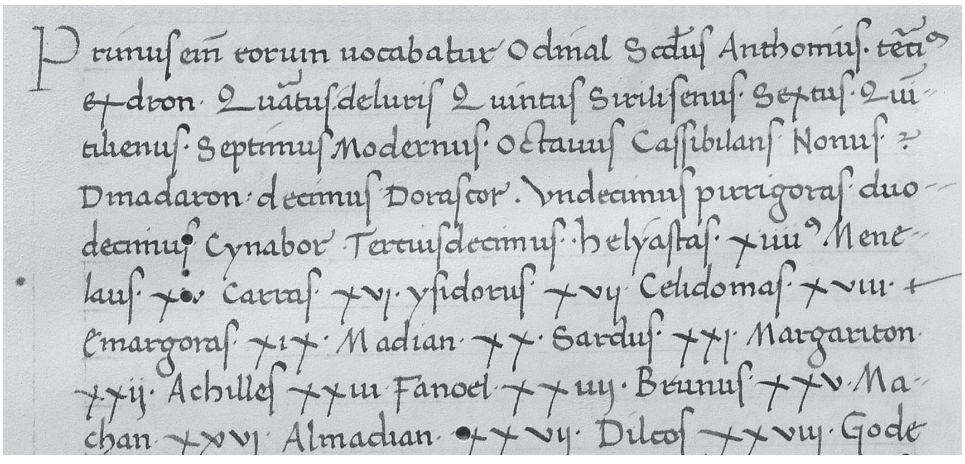

Kalocsa, Bibliothek der Kathedrale, Ms. 311, f. 167r (Detail) = Nr. 7

\section{Zusammenfassung}

Die Jahre zwischen 1476 und 1481 haben sich als grundlegend für die Entstehung der Bibliotheca Corvina erwiesen: in einem gewissen Sinne kam es während dieser Jahre $\mathrm{zu}$ einer bewussten Gründung derjenigen königlichen Sammlung, die heute Bibliotheca Corvina genannt wird. Die um das Jahr 1480 illuminierten Stücke der oben dargestellten Handschriftengruppe lassen zumindest darauf schließen. Folgende Schritte sind anzunehmen:

Wohl beeinflusst von der Ankunft der Königin Beatrix und ihres Gefolges in Buda wurde die Idee geboren, dass die königliche Bibliothek - nach italienischem Muster - einen würdigen Platz in der höfischen und königlichen Repräsentation einnehmen soll. Man kann auch nicht ausschließen, dass die im Palast schon vorhandenen verschiedenen Bücher und vielleicht sogar die oben betrachteten unvollendeten Handschriften die beteiligten Personen auf diese Idee brachten. Um die Absicht zu verwirklichen, waren aber gewisse 
Schritte nötig. Erstens ist wohl die Frage des Büchererwerbs aufgetreten. Abgesehen von den schon vorhandenen Handschriften schien der Regiomontanus-Nachlass ein wertvoller und erreichbarer Bestand gewesen zu sein. Um ihn zu erwerben - wie gesagt -, wandte sich König Matthias sogar an den Nürnberger Rat, aber seine Versuche blieben erfolgslos.

Eine andere Möglichkeit konnte die Lokalherstellung gewesen sein. Dafür war es nötig, eine Werkstatt im Palast zu errichten oder neu zu organisieren sowie Miniatoren und Buchbinder aufzunehmen. Namentlich kennen wir die beiden Miniatoren Francesco da Castello aus Mailand (Abb. 7, 8) und Francesco Rosselli aus Florenz (Abb. 2, 4). Rosselli hat sich im Jahr 1481 schon wieder in Florenz befunden, aber Francesco da Castello blieb wohl bis zum Tode von König Matthias hin in Buda und ist zur führenden Persönlichkeit der Budaer Werkstatt (und des Budaer Stiles) geworden.

In der Budaer Werkstatt war ebenfalls die Anwesenheit zweier unbekannterer Meister spürbar, unter ihren Notnamen des „ersten“ und des „zweiten Wappenmalers", die meist die Handschriften mit dem königlichen Wappen versahen Der „erste Wappenmaler“ illuminierte manchmal auch ganze Titelseiten. ${ }^{52}$ (Abb. 3, 11) Er war wohl ebenfalls ein italienischer Meister und könnte seine Budaer Tätigkeit zeitlich parallel mit Francesco da Castello und Francesco Rosselli angefangen haben.

Das erste zu minierende Material boten den Meistern wohl die oben präsentierten Handschriften, die entweder in Buda, im königlichen Palast, in der Umgebung des Hofes oder sogar in den ehemaligen Residenzorten von Johannes Vitéz de Zredna vorhanden waren. Diese unbemalten Abschriften wie gesagt - entstanden circa 10 Jahre früher, noch in den Jahren des regen kulturellen Treibens unter Vitéz, in Zusammenhang mit Regiomontanus, der Universität in Pozsony oder der eigenen Bibliothek von Vitéz. ${ }^{53}$ Dies kann also ein Grund für den großen Hiat gewesen sein, der zwischen der Ab-

52 Einige Beispiele: Bp., OSZK, Cod. Lat. 422.; Bp., OSZK, Cod. Lat. 428. (= Tafel, Nr. 6); Bp., OSZK, Cod. Lat. 429.; Bp., OSZK, Cod. Lat. 430., Jena, Universitätsbibliothek, Bos.8 .1.; Wien, ÖNB, Cod. 138; Wien, ÖNB, Cod. 140; Rom, BAV, Cod. Regin. Lat. 1715.

53 Der Anfangsbestand hat sich natürlich aus verschiedenen Bestandteilen zusammengesetzt, die im vorliegenden Aufsatz nicht zu betrachten sind. Nur eine Gruppe von Corvinen soll kurz erwähnt werden, die heute in der Budapester Universitätsbibliothek aufbewahrt werden. Die Gruppe besteht aus Codices, die von Vespasiano Bisticci in Florenz gekauft wurden und meist mit bianchi girari verziert sind. Ihre Texte wurden fast ausnahmslos von Johannes Vitéz de Zredna durchemendiert. Die Handschriften mussten also schon vor dem Tode von Vitéz im Jahre 1472 in Ungarn gewesen sein, aber man weiß bisher nicht, ob sie Vitéz' Eigentum oder das des Königs bildeten. Auf alle Fälle wurden diese Codices wohl ebenfalls im Rahmen der „Bibliotheksentwicklung“ um 1480 neu hervorgezogen und erhielten dann ihre CorvinenSamteinband. Auf ihre Titelseite hat der „zweite Wappenmaler" das Matthias-Wappen hineingemalt. (Zur Literatur s. Anm. 51). Im Gegensatz zur dargestellten Gruppe waren die Illuminationen vorhanden; es fehlten nur das Possessorwappen und der Corvineneinband, um diese Codices als Teile der repräsentativen königlichen Bibliothek zu erkennen. Man weiß nicht, ob diese Handschriften einen früheren Einband gehabt haben oder noch nicht. 
schreibzeit und dem Zeitpunkt des Illuminierens bei den fraglichen Handschriften besteht und der das Durcheinander bei ihrer Datierung verursachte.

In diesen Handschriften erscheinen mehrere Schreiberhände, stark geprägt durch italienische humanistische (hauptsächlich ferraresische) Schriftzüge.

Die vollendeten Handschriften mussten auch eingebunden werden, so war der Gedanke plausibel, auch einen Buchbinder in die Werkstatt des Palastes aufzunehmen. Es scheint wahrscheinlich gewesen zu sein, dass der angestellte Meister mit dem sog. "Corvinen-Buchbinder" identisch war. ${ }^{54}$ Hier muss erwähnt werden, dass bei der bewusst ausgestalteten Budaer Bibliotheksrepräsentation Einband, Wappen, Miniaturenschmuck, Buchschnitt und das auf dem Einband befindliche königliche Wappen miteinander eng zusammenhingen; sie waren in ihrem Stil voneinander abhängende Bausteine einer einheitlichen Konzeption.

Der Buchbinder entwickelte eigene Einbandtypen in der Budaer Werkstatt. Einerseits den Typ der Budaer Samteinbände: die Holzdeckel wurden in lilafarbigem oder rotem Samt eingebunden, darauf wurden entweder einfachere, meist blattförmige Schließbeschläge aus Messing oder solche durch Emailtechnik verzierte, vergoldete silberne Beschläge appliziert. Die Schließbänder wurden aus mit Gold durchbrochenem, grünem oder rotem Brokat hergestellt, schließlich gehörte ein durch bunte Ornamentik und Vergoldung verzierter Schnitt, der auch den Titel des Buches zeigte, zum vollendeten Einband.

Unsere Beispiele (Budapest, OSZK, Cod. Lat. 428., /Abb. 11/ Nr. 6; Cod. Lat. $\left.430 .{ }^{55} / \mathrm{Abb} .3 /\right)^{56}$ weisen darauf hin, dass vielleicht auch der andere Einbandtyp, der der vergoldeten Ledereinbände ${ }^{57}$, zur selben Zeit entwickelt

54 Seine Figur ist infolge der Existenz des einheitlichen vergoldeten Corvinen-Ledereinbandtyps geboren.

55 Die Corvine hat heute einen neuzeitlichen Pappeinband, aber ihr Schnitt läßt einen vergoldeten Corvinen-Ledereinband als originalen vermuten.

56 Weitere Parallelen (vergoldete Corvinen-Ledereinband, Illumination von dem ,ersten Wappenmaler"): Budapest, OSZK, Cod. Lat. 422 (Xenophon, De re publica), Cod. Lat. 429. (Bernardus Claraevallensis, De consideratione).

57 Zur Datierung der vergoldeten Corvinen-Ledereinbände gibt es nur wenige Anhaltspunkte, und zwar eher aus der Zeit um das Jahr 1490. Zum Thema im Allgemeinen s. vor allem die Werke von Marianne Rozsondai: „Die Bibliotheca Corviniana und die Corvineneinbände. Neue Erkenntnisse zu ihrer Beurteilung," in Bibliotheksmanagement - Kulturmanagement: Vorträge und Berichte. 24. Österreichischer Bibliothekartag, Congress Innsbruck, 3.-7.9.1996 (Biblos-Schriften 168), (Innsbruck: Biblios-Schriften-Admin., 1998), S. 337-360. Online unter http://www.mtak.hu/index.php?name=rozsondai_marianne_lecture.; Eadem, „Sulle legature in cuoio dorato per Mattia Corvino," in Nel segno del corvo. Libri e miniature della biblioteca di Mattia Corvino, catalogo della mostra, Modena, Biblioteca Estense Universitaria 15 novembre 2002 - 15 febbraio 2003, a cura di Paola di Pietro Lombardi, Milena Ricci (Il giardino delle Esperidi 16), (Modena: Il Bulino, 2002), 249-259; Eadem, „Über die Einbände der in München aufbewahrten Corvinen," in Ex Bibliotheca Corviniana. Die acht Münchener Handschriften aus dem Besitz von König Matthias Corvinus, hrsg. Claudia Fabian und Edina Zsupán, (Supplementum Corvinianum I, Bavarica et Hungarica I), (Budapest: OSZK, 2008), 143-152. Der oben vorgeschlagene Anfangszeitpunkt des Einbandtypes (1480) wird wiederum von gewis- 
wurde, weil sie - wie gesagt - in gewissen Fällen ebenfalls 10 Jahre früher abgeschriebene Handschriften bedeckten, wie oft die Samteinbände. ${ }^{58}$ (Abb, 15, Abb. 9) Bei den beiden erwähnten Corvinen war auch der Illuminator (der „erste Wappenmaler") identisch.

$\mathrm{Zu}$ den in einem vergoldeten Corvinen-Ledereinband neugebundenen Codices ist auch die Bessarion-Corvine zu zählen (Abb. 16), die wohl ebenfalls aus der Umgebung von Joahnnes Vitéz stammte. Sie bedurfte jedoch keiner zusätzlichen Illumination, weil sie schon von vornherein (mit bianchi girari) illuminiert war (Abb. 1) und wohl auch einen früheren Einband hatte.

Der obigen Analyse kann vielleicht entnommen werden, in welchem Maße die um das Jahr 1480 neuorganisierte königliche Bibliothek auf den Handschriften basierte, welche Ergebnisse der geistigen Beziehungen der ungarischen Elite um die Mitte des 15. Jh.s waren. Diese Beziehungen waren vor allem dem Johannes Vitéz de Zredna und seiner Umgebung zu verdanken, wie vermutlich auch die Tatsache, dass man diese Werke abschreiben ließ. Die Absicht des vorliegenden Aufsatzes war nicht, die Rolle der italienischen Schriftarten in der Repräsentation Johannes Vitéz' bzw. der ungarischen gelehrten Elite zu analysieren. Auf alle Fälle deuten zahlreiche Umstände darauf hin, dass man sie

sen Charakteristika des Einbandes des mit Sicherheit ungefähr auf das Jahr 1480 datierbaren Beatrix-Psalters (Wolfenbüttel, HAB, Cod. Guelf. 39 Aug. $4^{\circ}$ ) unterstützt: das Lederfiligrannetz wurde nämlich auf einen Ledergrund appliziert, dessen Eigenschaften (Farbe des Leders, Form der Holzdeckel, Proportionen des durch Golddruck ausgestalteten Schnurmusters usw.) an die vergoldeten Corvinen-Ledereinbände erinnern.

Laut der übereinstimmenden Meinung der Forschung hängt die Herstellung des Einbandes des Beatrix-Psalters und der sog. Erlangener Bibel (Erlangen, Universitätsbibliothek, MS 6) miteinander zusammen, infolgedessen ist auch der Einband der Bibel auf die Zeit um das Jahr $1480 \mathrm{zu}$ datieren. Und an der letzteren Corvine ist eine reiche Verwendung der verschiedenen Mittel des sog. Corvinenmeisters offensichtlich. Eine Tatsache, die ebenfalls circa die Zeit um das Jahr 1480 als einen Anfangszeitpunkt der Verwendung der von dem Corvinenmeister hergestellten, vergoldeten Corvinen-Ledereinbände suggeriert.

58 Das Dilemma „Samteinband oder Ledereinband“ wurde zu dieser Anfangszeit (um das Jahr 1480) vielleicht aufgrund der Größe des einzubindenden Codex entschieden. Charakteristisch wurden bei der Gruppe der ,"neuverwendeten“ Handschriften in einem vergoldeten Ledereinband die kleineren Stücke eingebunden, während die größeren Handschriften einen Samteinband erhalten haben. (Diese Unterscheidung hat sich später modifiziert.) Auf alle Fälle könnten die fraglichen kleineren Handschriften die erste Stücke gewesen sein, die mit einem vergoldeten Ledereinband versehen wurden. Meiner Hypothese nach könnte ein Grund dafür gewesen sein, dass der Corvinenmeister für diesen Einbandtyp und die Komposition wohl eine Vorlage gehabt hat und zwar einen ganz konkreten Codex bzw. Einband: den des Beatrix-Psalters. Vielleicht bekamen die kleineren Handschriften genau deswegen einen Ledereinband, weil auch das Musterstück, das Beatrix-Psalter (und seine Einbandkomposition) ein kleinformatiges Werk war. Dafür spricht auch die Tatsache, dass die fraglichen, kleineren, ersten Corvinen-Ledereinbände in ihrer Komposition fast ohne Ausnahme der Komposition des Einbandes des Beatrix-Psalters folgen. Allerdings ist die Erlangener Bibel ebenfalls zu einer Vorlage geworden. 
bewusst verwendete und dadurch wohl die Bestrebung ausdrückte, sich der führenden Kultur der Zeit, der italienischen, anzuschließen. ${ }^{59}$

Den zentralen Kern der neuen königlichen Bibliothek haben also wohl die in der oben dargestellten Weise hergestellten Codices gebildet.

Nicht nur die Bücher, sondern auch das geistige Erbe der früheren Kontakte zu Italien (der Platonismus, der Kampf gegen die Heiden, die Literatur um die Kirchenunion herum) war am Budaer Hof auch noch in den letzten Lebensjahren von König Matthias lebendig. Die Illumination der von Dániel Pócs analysierten, in den späteren achtziger Jahren angefertigten DidymusCorvine besteht genau aus diesen Elementen. ${ }^{60}$

Augustinus Moravus hat also durch seine Wahl bewusst oder unbewusst einen essentiellen Teil des Corvinenbestandes berührt. Bessarion musste ihm auf jeden Fall bekannt sein und auch die ersten Zeilen des Vorwortes von Sebastian Murrho zur Ausgabe von 1513 suggerieren, dass man Bessarion las und kannte.

Natürlich unter anderen Umständen als früher, aber auch am Anfang des 16. Jahrhunderts waren die Türkengefahr und die konfessionellen Auseinandersetzungen aktuell. Murrho resümiert den Inhalt der Epistola ad Graecos im Vorwort doch eigenartig: laut ihm erörtere Bessarion in seinem Brief, dass der Fall der Griechen dem zuzuschreiben ist, dass sie sich vom wahren Glauben (bei ihm von der ecclesia Romana) abgewandt haben. Bessarions Epistola enthält natürlich auch viel anderes, in unserem Kontext ist der Gesichtspunkt des Herausgebers interessant, der schon die protestantische Geschichtsanschauung assoziiert.

Und wenn Murrho schreibt, dass Augustinus Moravus die Handschrift e pulverulentis Pannoniae bibliothecis ${ }^{61}$ gefunden hat, sollen wir nicht denken, daß die königliche Bibliothek schon von Spinnennetzen umwoben war; es geht um einen alten Topos der Humanisten, der von Plinius dem Jüngeren an über Johannes Vitéz für mehrere Jahrhunderte beliebt war. Ebenfalls ein kleiner Faden, der verschiedene Epochen verbindet.

59 Man kann nicht ausschließen, dass auch einige Schreiber aus Ferrara in Ungarn tätig waren (vgl. z. B. die Schrift des Codex Nr. 1). Nicht nur die ferraresischen Schriftzüge, aber auch der übrigen Bestand der Bibliothek von Johannes Vitéz lässt uns komplexere Kontakte zur Residenzstadt von Borso d'Este vermuten.

60 Pócs Dániel, A Didymus-corvina. Hatalmi reprezentáció Mátyás király udvarában (Budapest: MTA Bölcsészettudományi Kutatóközpont, Müvészettörténeti Intézet, 2012).

61 Wie Anm. 3, Vorwort. 


\section{JANA KOLÁŘOVÁ \\ Latin Poems Dedicated to Stanislaus Thurzo, Bishop of Olomouc}

The rich and variegated neo-Latin literature, especially the copious neo-Latin occasional poetry, offers the possibility of examining the relationship between the members of the Humanistic learned societas both from the historical perspective and from the perspective of the manner in which this relationship is reflected by the texts.

With respect to the topic of this conference-that is, the person of the respected Humanistic scholar Augustinus Olomucensis - this paper will focus on a specific, narrow group of poetic texts that are closely connected with Moravia in the first half of the sixteenth century. These are panegyrical poems on Stanislaus Thurzo, the Bishop of Olomouc.

The Olomouc episcopate occupied almost the entire Moravian Margraviate and parts of Upper Silesia. When Thurzo ascended the bishop's throne (he was installed in his office in 1497), the episcopate was in decline.

We shall not describe all Thurzo's activities in his office which raised the significance of the region as the ecclesiastical and cultural centre. ${ }^{1}$ Let us just mention that, besides his ecclesiastical and political activities, it was Thurzo's education and interest in literature that earned him the respect and admiration of a number of Latin-writing poets, who ascribed to him volumes of their works, individual poems and other authors' works they edited. ${ }^{2}$ Just like the majority of scholars of the period, Thurzo was involved in res publica litteraria by means of copious correspondence, although he himself was not literarily active. For the sake of completeness, we should add that Thurzo's brother,

1 For the activities of Stanislaus Thurzo as Bishop, see Ivo Hlobil and Eduard Petrů, Humanism and the Early Renaissance in Moravia (Olomouc: Votobia, 1999), and, especially, Tomáš Baletka, “Dvůr olomouckého biskupa Stanislava Thurza (1497-1540), jeho kancelář a správa biskupských statků," Sborník archivních prací 54, no 1 (2004): 3-236. More secondary literature is given there.

2 Josef Hejnic and Jan Martínek, Rukovět’ humanistického básnictví v Čechách a na Moravě. S-Ž (Praha: Academia, 1982), 370-371. Johannes Dubravius dedicated to Thurzo his edition of Martianus Capella's De nuptiis Philologiae et Mecurii (1516); Beatus Rhenanus his edition of Tertullianus (1521); Erasmus of Rotterdam his edition of Plinius's Naturalis historia (1525); John Šlechta of Všehrdy his Mikrokosmos, which, however, does not survive. 
Johannes, was another important figure of the period. He became the Bishop of Wrocław and, like his brother, was a patron of poets. ${ }^{3}$

In the sphere of the Olomouc episcopate, which was favourable to Humanistic impulses (this inclination was visible already during Thurzo's predecessors, Tas of Boskovice and John Filipec), a group of learned ecclesiastics formed a loose society known as the Sodalitas Marcomannica (or Societas Maierhofiana). From the surviving correspondence, we can identify as the main inspirer of the society the German poet and Professor at the University of Vienna Conrad Celtis, whose work inspired a number of similar sodalitates, including the Sodalitas litteraria Danubiana. According to Martin Rothkegel, another ideological source of inspiration of this society was the biblical Humanism of Erasmus of Rotterdam. ${ }^{4}$

We know the names of most of the members of the society thanks to their correspondence, which was the group's major literary activity. ${ }^{5}$ Some of them, however, were significant European scholars and literary persons of the period (Augustinus Olomucensis, John Dubravius). In two well-known works of authors who mention the Olomouc Humanistic circle, we can find a list of these names. Georgius Sibutus, ${ }^{6}$ in the poem Ad potentissimum... Ferdinandum...

3 A number of scholars have researched the Olomouc Humanistic Centre; among others, they were Germans, for instance, Franz Babinger, Der mährische Humanist Stephan Taurinus und sein Kreis (Würzburg: Werkbund-Druckerei, 1944), Karl Wotke, “Der Olmützer Bischof Stanislaus Thurzó von Béthlenfalva (1497-1540) und dessen Humanistenkreis," Zeitschrift des deutschen Vereins für die Geschichte Mährens und Schlesiens 3, no. 4 (1899): 337-388, Peter Wörster, "Der Olmützer Humanistenkreis unter Stanislaus Thurzó," in Studien zum Humanismus in den böhmischen Ländern, ed. Hans-Bernd Harder and Hans Rothe (Köln - Wien: Böhlau, 1988), 21-37, Peter Wörster, Humanismus in Olmütz. Landesbeschreibung, Stadtlob und Geschichtsschreibung in der ersten Hälfte des 16. Jahrhunderts (Marburg: Elwert, 1994), and Czech, for instance, Rudolf Janál, "Stanislav Thurzo z Bethlenfalvy a Morava ve stycích se světem uherským a polským v posledních letech 15. a 1. pol. 16. stol." (PhD diss., Palacký University in Olomouc, 1949), Oldřich Králík, “Dvě zprávy o olomouckých humanistech," Časopis Matice moravské 68, no. 3-4. (1948): 283-327, and others. The already mentioned monograph by Ivo Hlobil and Eduard Petrů, Humanism and the Early Renaissance in Moravia (Olomouc: Votobia, 1999) offers a synthesis of contemporary findings. A recent contribution to the Stanislaus Thurzo scholarship is a study by the German historian Martin Rothkegel, entitled Der lateinische Briefwechsel des Olmützer Bischofs Stanislaus Thurzó (Hamburg: Lit, 2007). Apart from detailed information on the context of Thurzo's life and activities in the office, Rothkegel offers an edition of Thurzo's correspondence (114 letters in total). The letters contain a number of poems of praise that have become the basis for our research from which the present paper quotes.

4 Martin Rothkegel, "Nepřátelé-přátelé umění. Obrazoborectví a renesanční sběratelství v mikulovské křtěnecké reformaci (1526-1536)," in Sborník Regionálního muzea v Mikulově, ed. Stanislava Vrbková (Mikulov: Regionální muzeum v Mikulově, 2008), 118-134.

5 Ivo Hlobil and Eduard Petrů, Humanismus a raná renesance na Moravě (Praha: Academia, 1992), 30. In the context of the activities of the Societas Maierhofiana members, Petrü, hyperbolically, talks about "authors without literature." The monograph also offers more information on the Societas Maierhofiana as well.

6 For more detailed information on Sibutus, see for instance, Franz Machilek, "Georgius Sibutus Daripinus und seine Bedeutung für den Humanismus in Mähren," in Studien zum Humanismus 
panegyricus (published in Vienna in 1528), praises the city council of Olomouc and Bishop Thurzo and gives the list of names. Stephanus Taurinus (Stieröxel) did the same in his 1519 work Stauromachia: Augustinus Olomucensis, Martin Sinapinus, Jan Dubravius, Johannes of Zvole, Martin Göschl (Iglaviensis), Wenceslaus and Hadrianus of Vilhartice, Andreas Pisciculus (Fischer), Georgius Ranatinus etc. Most of these authors have been a subject of previous study, ${ }^{7}$ mainly with respect to their relationship to European humanists. The present paper is not going to discuss them, since-apart from the minimal amount of their purely literary activities - they did not write any poems dedicated to Bishops of Olomouc.

Apart from the scarce literary activity of the group in general, there might be one more reason for the lack of works dedicated to Thurzo: scholars such as Oldřich Králík, ${ }^{8}$ Eduard Petrů, Ivo Hlobil, and Martin Rothkegel ${ }^{9}$ have reconsidered the opinion of Karl Wotke and Peter Wörster, who called Thurzo the leader and patron of the Sodalitas Marcomannica members. It is mainly Rothegel who gives a number of explicit arguments why Thurzo could not fulfil this role (his seat, for instance, was in the town of Kroměřiž, not in Olomouc; most members of the sodality had already obtained their prebends and offices before Thurzo became Bishop; and when in 1504 Conrad Celtis visited Olomouc, he did not meet Thurzo at all, although he spent two months in the town). ${ }^{10}$ As far as Thurzo's closer contacts are concerned, there is surviving correspondence between him and Augustin Olomucensis and we know that he was a friend of the capitulary John Skála of Doubravka (also known as Johannes Dubravius), whom he called to his court in Kroměříž and who, after a short break, became Thurzo's successor as the Bishop of Olomouc. ${ }^{11}$

However, the largest number of poems dedicated to Bishop Thurzo were written by poets outside the Societas Maierhofiana, which ended its activities by 1510. These were mainly two authors of Silesian origin, Caspar Ursinus Velius and Georgius Logus.

in den böhmischen Ländern, ed. Hans-Bernd Harder and Hans Rothe (Köln - Wien: Böhlau, 1988), 207-241.

7 Oldřich Králík, "Moravský humanista Wolfgang Heiligmaier," Listy filologické 72, no. 2 (1948): 191-202.

8 Oldřich Králík, “Dvě zprávy o olomouckých humanistech," Časopis Matice moravské 68, no. 3-4. (1948): 283-327.

9 Martin Rothkegel, Der lateinische Briefwechsel des Olmützer Bischofs Stanislaus Thurzó (Hamburg: Lit, 2007), 58.

10 Rothkegel, Der lateinische Briefwechsel des Olmützer Bischofs Stanislaus Thurzó, 59. Martin Rothkegel even reverses the notion of the mutual influence between Thurzo and the Olomouc humanists: in his opinion, it was Thurzo who was influenced by the members of the Sodalitas Marcomannica-an influence that led to his interest in the work of Erasmus and other humanists.

11 Wolfgang Heiligmaier wrote a laudation upon Thurzo (Oratio ad reverendissimum in Christo patrem et dominum, dn. Stanislaum... episcopum Olomucensem, published 1515), which although not a poetic work, needs to be at least noted here. 
Caspar Ursinus Velius (c. 1493-1539) studied in Cracow and Leipzig. During his subsequent stay in Rome, he got acquainted with Italian humanists. Upon his return to Silesia, he was initially supported by the Bishop of Wrocław Johannes Thurzo, and, after his death, by Johannes's brother Stanislaus. Later, in Basil he met Erasmus of Rotterdam and arranged written communication between him and the Bishop of Olomouc. Ursinus taught rhetoric at the University of Vienna and served Emperor Ferdinand I. ${ }^{12}$

Ursinus is the author of one of the most famous pieces dedicated to Thurzo, entitled Thurzeis ${ }^{13}$ (or rather of its 179-line prelude Thurseidos praeludium). The originally planned long poem was supposed to be worthy of the importance of Thurzo's family. However, the remaining parts that the author had promised never came into being. The poem starts with a long invocation to Apollo (Aoniae dux summe lyrae, dux optime vatum, Phoebe pater), who has the power to lend immortality through poetry, as he did to famous heroes in the past. Employing the ubi sunt topos, Ursinus mentions the fame of cities and empires, whose reputation can only be preserved by the art of poetry, since they were ruined by the merciless time. The speaker asks Phoebus and the Muses for help when he, following the example of Homer and Virgil's epic poems, wants to celebrate the whole of the esteemed family of the Thurzos. ${ }^{14}$ The following passages, too, are replete with classical images, although they are mostly conventional. The father of the house, Johannes Thurzo, is blessed and immortal, since his offspring is copious and famous, in education and manners similar to their father, especially the sons John and Stanislaus, who are both bishops. Our focus is, however, the question of patronage and how it is reflected in the text. ${ }^{15}$

Let us, therefore, determine the ways in which patronage is represented in his texts and, on their basis, describe the image of Thurzo as a patron. ${ }^{16}$

In Thurzeis, a number of motifs are present that are characteristic of this kind of work. The theme of the poem itself, that is, the genealogy and laudation of the patron's family, was a commonplace, given that the patron came from

12 Josef Hejnic and Jan Martínek, Rukovět humanistického básnictví v Čechách a na Moravě. S-Ž (Praha: Academia, 1982), 423-424.

13 The following quotation from the poem is from Rothkegel, Der lateinische Briefwechsel des Olmützer Bischofs Stanislaus Thurzó, 150-155.

14 Rothkegel, Der lateinische Briefwechsel des Olmützer Bischofs Stanislaus Thurzó, 150-151.

15 Eduard Petrů notes that Caspar Ursinus was indeed supported by Stanislaus Thurzo and established contact between the Bishop and prominent European humanists. See Ivo Hlobil and Eduard Petrů, Humanismus a raná renesance na Moravě (Praha: Academia, 1992), 28.

16 In many respects, an inspiration for the present analysis was Lucie Storchová's study Paupertate styloque connecti, which contains a chapter devoted to various forms and representations of the patron-poet relationship in the sphere of humanistic scholarship, chiefly demonstrated by the example of John Hodějovský of Hodějov's patronage. See Lucie Storchová, Paupertate styloque connecti. Utváření humanistické učenecké komunity v českých zemích (Praha: Scriptorium, 2011). 
an ancient and noble house. A common feature of these works was also a list of excellent characteristics, often collectively described as virtus. More importantly, the renewal of cathedrals and other buildings are also activities for which Stanislaus deserves to be praised. In the texts the motif of good shepherd also appears, protecting his flock against wolves (this image is also linked with Thurzo's mission as a bishop).

On the lexical level, the poem is-just like other panegyrics-full of adjectives and adverbs in the superlative form (vestrae clarissima lumina gentis; vestrae ratio sanctissimae vitae; Moecenas hominum optime optimorum et cetera) and periphrastically hyperbolised addresses of the patron (o dulces animae nostrae solatia vitae; pontificum decus bonorum et cetera).

Ursinus decided to make the conventional statement more unique and special in the piece with the incipit Thurso, pontificum decus bonorum. The laudation is part of a formal poetic game (you can notice the position of the name "Thurso" in the individual lines):

Thurso, pontificum decus bonorum, Gentis, Thurso, tuae perenne sydus, Aevi gloria, Thurso, magna nostri, Felix materia euge, Thurso, vatum, Modis omnibus absolute Thurso... ${ }^{17}$

Thurzo's name can be celebrated with any metrical foot, any poetic line, following the example of Homer, Callimachus, Horace or Catullus. The second half of the poem is more traditional-just like the Sun shows his face after a sea storm, Thurzo's gentle face gives Ursinus comfort in the middle of disasters. ${ }^{18}$

The corpus of Ursinus's works of the genre about Thurzo's family is completed by a funeral ode, which has a unique position due to its strikingly personal character. Its title is Ad Stanislaum Thursonem de obitu fratris consolatio and was published in 1521. It contains traditional topoi of consolatory works, such as the bidding of Stanislaus not to weep for his brother too long, since Stygian gods cannot be softened. Let Johannes's fame and glory, which are still alive, be Stanislaus's consolation. Perhaps even more than in the case of Stanislaus Thurzo, Johannes's activity as a patron of arts is stressed (of course, with the use of a repertoire of classical motifs). Indeed, he is even compared

17 Rothkegel, Der lateinische Briefwechsel des Olmützer Bischofs Stanislaus Thurzó, 208.

18 Ursinus also dedicated some poems to another of Johannes Thurzo's sons, Alexius. For instance, Ad magnificum dominum Alexium Thursonem, in which the author, together with Georgius Logus, wants to spread the fame of the house of Thurzo "from West to East", although no poet can, in his opinion, praise them properly: Beatam Thursonum vere magnificamque domum, carmine quae Veli quocunque Logique rotundo nota sit Eois, nota sit Hesperiis! see Rothkegel, Der lateinische Briefwechsel des Olmützer Bischofs Stanislaus Thurzó, 207. 
to Maecenas, for whom Virgil secured everlasting glory. Around the middle of the work, the epicedium turns into a panegyric on Stanislaus Thurzo. Using the topos of false humility (or dubitatio), Ursinus expresses his desire to contribute with his lowly Muse to spreading Stanislaus's fame, since he cannot be silent about the benefits he has received. A lengthy description follows, comparing the Bishop of Olomouc with the classical hero Heracles. Thurzo is different from the mythical hero in all aspects (the phrase non..., sed is repeated many times): instead of violence and anger, the Bishop excelled in wisdom, peacefulness, education, generosity and piety; he was not crowned with Jupiter's leaves, but with bishop's gold tiara decorated with pearls, et cetera. Decorated with these virtues, Stanislaus Thurzo walks towards immortality and holiness. ${ }^{19}$

In the context of courtly and aristocratic patronage, some scholars mention the motif of the topographic description of a court, including a list of properties or subjects. A form of this topos can be found in Ursinus's 1524 poem De oppido Cremsyrio Moraviae, ductu... episcopi Olomutzensis instaurato. Unlike the majority of pieces of this kind, whose impressiveness is based on opulent lists and detailed descriptions, the text of De oppido Cremsyrio is rather short: it has only eight lines. The town of Kroměříz is not described at all, just Stanislaus Thurzo's credit of promoting the town and making it comparable to Rome. Thurzo is identified with the restorer of Rome, Emperor Augustus. The poem is therefore a cross between laus urbis and panegyric.

As far as the description of the city and its surroundings is concerned, Jacqueline Glomski, ${ }^{20}$ in the context of Valentine Eck's poetry, talks about an "idyllic description of felix Olomuncia, inhabited by the Muses". In the poems of Caspar Ursinus (especially in Thurseis praeludium), we can find typical motifs combining the Moravian topography (Olomouc and its vicinity) with the typology of classical mythos, referring to poetic art and Apollo's circle (Parnassus, Boeotian Helicon, Tempe, Peneios and others). For the sake of comparison, let us mention Simon Ennius of Klatovy, an author a generation younger, who in his 1550 poem Breve encomion Olomutii metropolis, writes: Around Olomouc, there are also woods and forests full of green, in which naked Diana dances and then hunts hares. [...] The beautiful mother of Bacchus, unhappy Semele, allegedly died in this place, struck by Jove's lightning. ${ }^{21}$ For Caspar Ursinus, these images symbolise the fact that, thanks to Stanislaus Thurzo's support, classical scholarship and Renaissance poetry have come to Moravia.

In concluding this short analysis, it is argued that despite a number of typical motifs and themes, Thurzo was not a traditional patron to Caspar

19 Rothkegel, Der lateinische Briefwechsel des Olmützer Bischofs Stanislaus Thurzó, 172-175.

20 Jacqueline Glomski, Patronage and Humanist Literature in the Age of the Jagiellons (Toronto: University of Toronto Press, 2007), 109n.

21 Šimon Ennius Klatovský, "Krátká chvalořeč na Olomouc," in Humanisté o Olomouci, ed. and trans. Eduard Petrů (Praha: Památník národního písemnictví, 1977), 42. 
Ursinus Velius, the way, for instance, John Hodějovský of Hodějov was - that is a patron whose support not only enabled the author's literary activities, but also satisfied his existential needs. Although Ursinus called the Bishop of Olomouc a patron, it is obvious from his poems that the Bishop's private help was not as important as his public credit and his character. Nor can we find a single mention identifying Thurzo as a leader of a circle of poets.

As we shall soon see, the representation of Stanislaus Thurzo in the works of the poet Georgius Logus (c. 1500-1553), who was a close friend to his fellowcountryman Ursinus, is somewhat different. Both poets were initially supported by Bishop of Wrocław Johannes, and later by Bishop of Olomouc Stanislaus Thurzo. Logus was also financially supported by Stanislaus during his later studies in Bologna, Padua and Rome. The Bishop's help was surely not insignificant and Logus was often existentially dependent upon his patron. According to Lucie Storchová, the motif of the paupertas is one of the foundation blocks of the strategy of gaining and preserving the relationship between the patron and the client. ${ }^{22}$ In this case, the employment of this strategy is obvious. Georgius Logus later gained the position of secretary to Emperor Ferdinand I, which he kept for the rest of his life. ${ }^{23}$

In his poems (mostly from his collection Hendekasyllabi, elegiae et epigrammata, published in Wien in 1529), Logus sometimes pleads with the patron to support him financially or, at least, asks for an intercession, pointing out specific benefits which Thurzo provided for him in the past. Unlike Ursin's works, Logus's poems are personal confessions, in which their author describes at great length difficulties which he got into, often in an elegiac tone (Quid faciat miser, ah miser et male perditus ille? Quanti huic ex tristi corde fluunt gemitus?). ${ }^{24}$ Thurzo is represented not just as a patron, but also as a saviour from suffering, hunger and poverty.

The author considers his connection with Thurzo as a stroke of happy fortune (tibi me bona fata reducunt). Motifs such as shipwrecking at sea and abandonment by all friends and relatives - of which only Thurzo remained occur repeatedly. More often than in Ursinus's works, the patron is addressed as pater. Naturally, Logus, too, makes frequent use of superlatives (sacer heroesque inter mitissimus omnes; dimidium vitae, Turso, decusque meae) and employs a popular paraphrase of Ennius's line aeternum volitat per ora virorum.

In one of his poems, Logus invokes Apollo himself and the Muses to help him to return to his friends in beloved Rome. Calliope replies that, because of the war and other troubles, Thurzo does not have enough financial resources, but he will try to obtain some from an offspring of imperial blood (meaning

22 Storchová, Paupertate styloque connecti, 131n.

23 Josef Hejnic and Jan Martínek, Rukovět' humanistického básnictví v Čechách a na Moravě. K-M (Praha: Academia, 1969), 207.

24 Rothkegel, Der lateinische Briefwechsel des Olmützer Bischofs Stanislaus Thurzó, 212. 
Emperor Maximilian I's grandson, the then future King and Emperor Ferdinand I, whose secretary Logus later became). In some poems, Logus does not hesitate to formulate very specific requests for articles of clothingfor instance, a long coat, which would replace the modest clothing of the follower of Pallas Athena and in which he would be able to go to war. In another poem, written during Ferdinand's expedition against John Zápolya, which Logus himself joined, he asks for a warm fur-coat, complaining that he is terribly cold and his fingers are freezing, that not only can he not write poetry, but his life is at risk. A poetic homage, which perhaps Thurzo expected, therefore cannot come unless Logus receives requested clothing.

A poem with the incipit Xenia respondi poscentibus annua multis ${ }^{25}$ could even be interpreted as psychological blackmail-or a humorous hyperbole. Logus claims that he will keep his word to give his friends New Year gifts only after he has received a contribution from Thurzo (ipse dabo vobis, cum mihi Turso dabit), explicitly saying: Ut donem eis aliquid, des mihi, Turso, aliquid. At any rate, it is obvious how a figuration of a poetic "gift" to a patron works here: the poems are called gifts, but they are also conditioned by specific requests to the patron. ${ }^{26}$

Logus's last farewell to his former protector and patron is in Stanislai Tursonis tumulus - a surprisingly conventional and rather impersonal piece. The imagery of the poem is uninventive-it is the same as in many other epitaphia, for instance, the weeping of Apollo, Muses and Charites, the weeping of Bohemian and Moravian lands (serving as the topos of a loss for the country). The poet, however, forbids weeping, since the heavens opened for Thurzo, where he can go on being a supporter of his studiosa cohors. ${ }^{27}$

25 Rothkegel, Der lateinische Briefwechsel des Olmützer Bischofs Stanislaus Thurzó, 233-234.

26 Storchová, Paupertate styloque connecti, 126, 131. Georgius Logus also contributed to an addition to Johann Fabri's volume Sermones aliquot salubres... adversus nepharios et impios Anabaptistas habiti (published in 1528) with a lengthy panegyric dedicated to Thurzo, but with respect to the thematic scope of the volume, the poem is mostly about encouraging Fabri and Thurzo in their fight against heretics and dissenters. Through classical war motifs, both the poem's protagonists are stylised as warriors against the enemies of the Church. A similar theme can be found in a poem included in a volume entitled Hendekasyllabi, written to wish Stanislaus Thurzo happy Christmas. The author laments over the conflicts in the Church and asks Christ to protect the Bishop and give him a long life, since Thurzo is a castae religionis amor.

27 Although both Ursinus and Logus were gifted poets, we should not forget that neo-Latin poetry of European Humanism is very often openly an aemulatio veterum. The poets' favourite author who expresses their relationship to their patrons was Horace, namely his Carmina and Epodes, dedicated to Maecenas. As Josef Hejnic and others note, this poet's popularity in Bohemia is chiefly connected with Jan Hodějovský and his poetic circle, in whose texts most paraphrases of Horace's lines are. Although several allusions to Horace can indeed be found in some of the poems dedicated to Thurzo (Logus: dimidium vitae, Turso, decusque meae) and Horace's formal inspiration is obvious, we can also see that in neo-Latin poetry the influence of classical authors is mixed with early-modern poetic conventions. 
Our short excursus into dedicatory poems their authors ascribed to one of the most important persons of early Humanism in Moravia shows how important Thurzo's role was in supporting students, writers and scholars. In spite of the expected level of hyperbolising, it is obvious that a number of scholars and authors were indeed influenced by the power of Stanislaus Thurzo's personality and his deeds, including his more general political and ecclesiastical activities, as wells as specific material help to individuals. Thurzo's patronage and its representation in occasional poetry can be considered as one of many proofs of how strong the impulses of Renaissance Humanism were in Moravia. We can also state that, besides Thurzo's stylised image in formalised literary works, the texts in question also indicate the Bishop's extraordinary human qualities, expressed by the repeatedly mentioned virtus. 



\title{
LUCIE STORCHOVÁ
}

\section{The "Apostle" of Renaissance Humanism in Moravia?}

\author{
Re-Figuring Augustinus Olomucensis \\ in Modern Czech Historiography ${ }^{1}$
}

Through the analysis of Renaissance Humanism in Olomouc, the most general aim of this paper is to show how the fact that historians represented certain past "events" as cultural transmissions relates to the politics of $19^{\text {th }}$ - and $20^{\text {th }}$ century cultural identities. In this case, it will be examined how "Renaissance Humanism" was understood as a transmission of civilizational values from Western Europe (most often from Italy) to Central Europe. Using the example of Augustinus Olomucensis as the chief "apostle" of Olomouc humanism, I will endeavour to show how the transmission of humanist education to Olomouc is described in historical works in the mid-nineteenth century. The following questions are crucial to my approach: When did historians begin to conceptualise Renaissance Humanism in Olomouc as cultural transfer? How did they describe this transmission and its key players (above all Augustinus)? My second set of questions covers the issue of how the use of the category "transmission" can be related to the values and ideologies of the communities that produced this knowledge about history. Finally, I will discuss the share they may have had in shaping $19^{\text {th }}$ - and $20^{\text {th }}$-century cultural identities.

\section{Representing Renaissance Humanism as a cultural transfer}

Along with Jörg Feuchter, Friedhelm Hoffmann and Bee Yun, editors of Cultural Transfers in Dispute: Representations in Asia, Europe and the Arab World since the Middle Ages, ${ }^{2}$ all cultural transfers are primarily constructs of

1 This publication was made possible by funding from the Grant Agency of the Czech Republic (GAČR) and was prepared within the grant project No. P410/11/1201 Jan Amos Komenský jako místo paměti. Polyvalentní imaginace paměti a (re)konstruování kánonu administered by the Institute of Philosophy of the Czech Academy of Sciences, Prague.

2 Jörg Feuchter, Friedhelm Hoffmann and Bee Yun (eds.), Cultural Transfers in Dispute: Representations in Asia, Europe and the Arab World since the Middle Ages (Frankfurt am Main and New York: Campus Verlag, 2011). I developed this conceptual framework also in Lucie Storchová, "The Role of Trans/National Meta/Narratives in Representations of Cultural 
researchers and their existence-especially in earlier times-is often postulated on the basis of minimal source evidence. The moment a historian decides to define something as a "transfer," collective values and ideological backgrounds necessarily come into play. On this basis, only certain cultural phenomena are considered of sufficient value to be transferred into another culture. In the same way, ideas about the hierarchy of the exporting and the receiving culture are often projected into the way in which transfers are described; the transmission is then represented as, for example, progress, or civilizational speeding up. The very fact historians represent some historical phenomena as transmissions (be it just implicitly, "as a matter of course"), makes it possible to create a connecting line between cultures, or even to unify them into new wholes. This represents one of the many ways in which discourse about "us" and "them" is produced. Cultural transmissions may become part of stories by which nations and other imagined communities produce their cultural identities and through which they legitimise their politics (a classic example is the history of how a particular nation rose to power and became civilized).

As Feuchter points out, the differences between various representations of cultural transfers may be very subtle, thus knowing which imaginations or ideologies they should be linked to is not necessarily straightforward. ${ }^{3}$ In the case of descriptions of Renaissance Humanism, it was from the second half of the nineteenth century that European historians began to apply a relatively clear value context and figurative speech. Humanism was conceived as a set of civilizational values transferred, thanks to the activity of scholarly "apostles," from Italian territory to other Western European intellectual centres and thence to further semi-periphery and periphery regions of Europe. Renaissance Humanism was considered a crucial step in the story of how modern Western civilisation emerged. Thanks to this reading, "periphery areas", including Bohemia and Moravia, acquired the possibility of playing a role in what was seen the most important turning point of Western history. By producing knowledge on Renaissance Humanism, modern nations won an opportunity to present themselves as communities capable of achieving the standards of such a civilisation and "high culture". This bond to the politics of national identity may also have been the reason for the legitimacy and longterm support this research has enjoyed since the nineteenth century in parallel with the unflagging interest of historians, above all on the "peripheries," in issues of humanist erudition and Latin humanist literature.

Transfer: The Case of European and Bohemian Renaissance Humanism/s", in Processes of Cultural Exchange in Central Europe, 1200-1800, ed. Veronika Čapská (Opava: European Social Fund-Silesian University in Opava), 35-75.

3 Jörg Feuchter, "Cultural Transfers in Dispute: An Introduction", in Cultural Transfers in Dispute. Representations in Asia, Europe and the Arab World since the Middle Ages, ed. Jörg Feuchter, Friedhelm Hoffmann and Bee Yun (Frankfurt am Main and New York: Campus Verlag, 2011), 24. 
This way of thinking led to a reduction of varied intellectual practices in "Renaissance Humanism," understood as a homogenous cultural phenomenon. Researchers focused their attention on local "cultural icons"; that is, on each scholar who mediated contacts between the centre and the peripheries. It would be emphasised in his biography whether he had studied in Italy or with important scholars close to an alleged "civilisation centre", or had possibly been in correspondence with such scholars, and supported in his studies by the editing of humanist letters. Unsurprisingly, metaphors of the transmission of "light" to a "dark territory", often connected with the idea of overcoming the "dark" Middle Ages, were applied on a figurative level; refiguring terms that had been used by many Central European humanists themselves, modern historians described humanists as "apostles" or "torch bearers".

\section{The man who transmitted Renaissance Humanism to Moravia: Interpretations through the lens of Moravian Landespatriotismus and Czechoslovak nationalism}

The way historians described the figure of Augustinus Olomucensis is a telling example of such an approach. After a short mid-19th -century period when he was interpreted through the lens of the Moravian Landespatrotismus (in F. X. Richter's 1831 edition of Series, for instance), ${ }^{4}$ cultural transfer became more and more crucial for his biographers. According to them, Augustinus played the most important role in the transmission of Humanism to Olomouc and the whole of Moravia. In the course of this, the question of the transmission itself is characteristically topical and is in the focus of very recent research; it is apparently "obvious" and not even contemporary researchers "can evade it." 5

We encounter several ways of presenting Humanism as a cultural transmission to this territory in existing research on scholars active in Olomouc, the Moravian historic metropolis, centre of the Haná region and seat of a bishopric, at the end of the fifteenth century. Here, let me just make a short remark on sources. One of the leading experts on early Bohemian and Moravian literature, Eduard Petrů already described Olomouc humanists' Latin production as "exceptionally meagre." He even characterises Olomouc humanists as "writers without any literature." 6 Owing to the minimal amount

4 Augustini Olomucensis episcoporum Olomucensium series, quam recensuit, continuavit, notisque historico-chronologicis illustravit Franciscus Xav. Richter, ss. theologiae bacalaureus, historiae universalis professor emeritus, nunc Caesareo-Regiae Universitatis Olomucensis bibliothecarius et archiepisc. consil. tit., Olomucii, characteribus Aloysii Skarnitzl, 1831.

5 Nor did I in my earlier studies; cf. Lucie Storchová, "Latinský humanismus", in Dějiny Olomouce, Vol. 1, ed. Jindřich Schulz (Olomouc: Univerzita Palackého, 2009), 303-308.

6 Eduard Petrů, "Societas Maierhofiana”, Historická Olomouc a její současné problémy 3, 1980, 183; Eduard Petrů and Ivo Hlobil, Humanismus a raná renesance na Moravě (Praha: Academia, 1992), 30 and 33. 
of sources preserved, discussion about the place from which Humanism was transferred to Olomouc may appear completely disproportionate. However, the thinness of the source evidence does not have to be in itself an obstacle to the representation of cultural transmission. On the contrary, it can enable researchers to draw ever more complex pictures, which then contribute to creating cultural identities.

In the case of early research into Olomouc Humanism, a significant civilizational paradigm gains recognition when, by means of a description of scholarly contacts and influences, historians confirm the membership of a given territory in the European civilizational project and its values. Also, mid-19th - century historians in Moravia developed the framework of the humanist civilizational project. The dispute among them about the origin of Olomouc Humanism was only partially nationalised. ${ }^{7}$ On the part of German-speaking historians, who cooperated with Verein für Geschichte Mährens und Schlesiens, Augustinus's civilizing mission was related to the whole region of Moravia, not particularly to one "national community" living here. They also tried to identify all possible centres that may have transmitted the new intellectual movement. From the 1890s onwards, Karl Wotke and later Gustav Bauch summarized their research in empirically substantial articles. ${ }^{8}$ Wotke's articles were the first to emphasise the Olomouc humanists' European ties and show that at the beginning of the sixteenth century Olomouc was not some "Barbarenlande" but rather "ein Musensitz ersten Ranges," ${ }^{\prime 9}$ on which the attention of the whole of what was at that time the literary world was concentrated. This attachment is illustrated by the fact that Wotke made a short edition of the correspondence between the Olomouc bishop Stanislav Thurzo and a humanist cultural hero: no less than Erasmus of Rotterdam. ${ }^{10}$

Wotke depicted the life-time of Augustinus as the dawn of Humanism in Moravia ("das Morgenlicht der humanistischen Ausbildung in Mähren") and at the same time, as the short-lived Golden Age of local intellectuals ("Augustin

7 In this perspective, we can agree with the recent analysis made by David Kalhous, according to which a distinctly nationalist interpretation can only seldom be found on the pages of Zeitschrift des Vereins für Geschichte Mährens und Schlesiens at the turn of the century. David Kalhous, "Osudy jednoho časopisu. Zeitschrift des deutschen Vereins für die Geschichte Mährens und Schlesiens", in Německá mediavistika v českých zemích do roku 1945, ed. František Šmahel and Pavel Soukup (Praha: Filosofia, 2004), 97.

8 Karl Wotke, "Augustinus Olomucensis (Augustinus Käsenbrot von Wssehrd)", Zeitschrift des deutschen Vereins für die Geschichte Mährens und Schlesiens 2, 1898, 47-71; Karl Wotke, "Der olmützer Bischof Stanislaus Thurzo von Bethlenfalva (1497-1546) und dessen Humanistenkreis", Zeitschrift des deutschen Vereins für die Geschichte Mährens und Schlesiens 3, 1899, 337-388; Gustav Bauch, "Zu Augustinus Olomucensis", Zeitschrift des deutschen Vereins für die Geschichte Mährens und Schlesiens 8, 1904, 119-136.

9 Wotke, "Augustinus Olomucensis", 58.

10 Wotke, "Augustinus Olomucensis", 58 and 66; Wotke, "Der olmützer Bischof Stanislaus Thurzo", 376f. 
und sein Bischof Stanislaus Thurzo verstanden es, die Aufmerksamkeit des gesamten literarischen Welt auf Mähren, ja auf Olmütz zu lenken, was nach ihnen leider niemandem mehr gelungen ist. "). ${ }^{11}$ He then considers Augustinus not only as"der grösste Humanist Mährens" and "Förderer der neuen Geistesrichtung" but also as "ein echter Sohn der Renaissance" devoting himself to studying, writing letters, collecting ancient coins and drinking in symposia. ${ }^{12}$ What is also striking is that Wotke reduced all connections of Augustinus' work to late medieval literature. He devoted considerable space to Dialogus in defensionem and Augustinus's allegedly last work Antilogion published in Vienna in 1512 ("So finden wir unseren Dompropst wieder am Ende seines Lebens mit einem streng humanistischen Thema beschäftigt; er ist also seiner Jugendliebe nicht untreu geworden. $\left.{ }^{\prime \prime}\right) .{ }^{13}$

The roots of a nationalist approach are visible in the discussion in Czechoslovak historiography from the early 1930s onwards concerning the question of Augustinus's ethnicity and the extent to which Humanism in Olomouc can be interpreted as a part of Czech intellectual history. Needless to stress, Augustinus's original surname, Käsenbrot, which was also his father's surname, gave relatively little room to Czech nationalist historians. But what about his mother? As regards the minimal source evidence remaining after her, we know only her first name, Markéta, and her brother's name, Ondřej Ctiborův. Czech historians involved in the discussion came to an agreement that she must have been "of Czech origin" and taught Augustin Czech as his mother tongue. ${ }^{14}$

\section{The search for the place that transmitted Humanism to Moravia}

Although Wotke already mentioned the relationships of the Olomouc and Vienna humanists, in papers written from the late 1950s onwards there is a striking emphasis on the "non-German" bonds of Olomouc scholars, specifically on the transmission from Polish and Slovak regions. ${ }^{15}$

11 Wotke, "Augustinus Olomucensis", 66.

12 Wotke, "Augustinus Olomucensis", 65-66.

13 Wotke, "Augustinus Olomucensis", 65-66.

14 See for instance: Václav Nešpor, "O původu moravského humanisty dr. Augustina Olomouckého", Český časopis historický 38, 1932, 541-546. For Augustinus's knowledge of the Czech language and that he was "a Czech", see Vincenc Prasek, "'Augustin doktor' a Olomoučané", Časopis Matice moravské 26, 1902, 30-42. Information on Augustinus's Czech mother could be found in very recent works too; Historiografie Moravy a Slezska, Vol. 1, ed. Ivo Barteček (Olomouc: Univerzita Palackého, 2001), 14.

15 Petrů and Hlobil, Humanismus a raná renesance, 27; Eduard Petrů, “Olomoucký humanismus a jeho polské podněty", in Slavistický sborník olomoucko-lublinský (Praha: SPN, 1974), 27f; Humanistická konference 1966, ed. Jaroslav Vorel (Praha: Kabinet pro studia řecká, římská a latinská, ČSAV, 1966), 101f; Josef Macůrek, “Turzonowie na Morawach i na Śląsku na końcu XV I w pierwzsej połowie XVI wieku. Z historii stosunków czesko-polskich w okresie 
Eduard Petrů, more than any other researcher, came forward with the idea of the "openness" of Olomouc to European intellectual influences, based on the continuity of "humanist efforts" in Olomouc from the time of Johannes Noviforensis's episcopacy (1364-1380). ${ }^{16}$ This interpretation anticipated elements of cultural transmission: even in this early phase, the Moravian metropolis appears to have had ties to Italy and seems to have been open to cultural influences. Augustinus was an especially important author here, because of being "connected to the best of European Humanism." At the same time, however, Petrů emphasised the idea of the indigenous persistence and continuity of Humanism in Moravia with minimal external influence. From the point of view of the concept of the representation of cultural transfers, it is interesting that the bond with Buda (and also with Vienna, as will be discussed below) as secondary intellectual centres brings in the question of the primary centre, Italy, as the cradle of humanist civilisation. Developing Petrù's framework, Czech scholars in the early 1990s emphasised this strong link to the very heart of Renaissance Humanism.

From the mid-1990s, on the other hand, Peter Wörster drew attention to the affinity of Olomouc humanists with the intellectual world of Conrad Celtis. ${ }^{17}$ This thesis is widely accepted in German research today ${ }^{18}$ and has slowly spread also in Czech research. ${ }^{19}$ If we leave aside the administrator bishop Jan Filipec and his Buda contacts, according to Wörster there is no link

humanizmu," Śląnski kwartalnik historyczny Sobótka 14, 1959, 25-47; Josef Macůrek, "Humanismus v oblasti moravsko-slezské a jeho vztahy ke Slovensku v druhé polovině 15. a počátkem 16. století," in Humanizmus a renesancia na Slovensku v 15. a 16. storočí, ed. Ludovít Holotík and Anton Vantuch (Bratislava: Slov. vydav. akadémie věd, 1967), 335f.

16 Petrů and Hlobil, Humanismus a raná renesance, 14-16; Eduard Petrů, Vzdálené hlasy (Olomouc: Votobia, 1996), 196f and 222; Eduard Petrů, “Olomoucká literatura nebo literatura v Olomouci?," Historická Olomouc a její současné problémy 4, 1983, 273 f.

17 Peter Wörster, "Der olmützer Humanistenkreis unter Stanislav Thurzo," in Studien zum Humanismus in den böhmischen Ländern, Bd. 11, ed. Hans-Bernd Harder and Hans Rothe (Köln and Wien: Böhlau, 1988), 52f; Peter Wörster, Humanismus in Olmütz. Landesbeschreibung, Stadtslob und Geschichtsschreibung der ersten Hälfte des 16. Jahrhunderts (Marburg: Elwert, 1994), 47f; Peter Wörster, "Breslau und Olmütz als humanistische Zentren vor der Reformation," in Humanismus und Renaissance in Ostmitteleuropa vor der Reformation, ed. Winfried Eberhard and Alfred A. Strnad (Köln, Weimar and Wien: Böhlau, 1996), $222 \mathrm{f}$.

18 Hans Bernd Harder, "Zentren des Humanismus in Böhmen und Mähren," in Studien zum Humanismus in den böhmischen Ländern, Bd. 11, ed. Hans-Bernd Harder and Hans Rothe (Köln and Wien: Böhlau, 1988), 29; Franz Machilek, "Konrad Celtis und die Gelehrtensodalitäten insbesondere in Ostmitteleuropa," in Humanismus und Renaissance in Ostmitteleuropa vor der Reformation, ed. Winfried Eberhard and Alfred A. Strnad (Köln, Weimar and Wien: Böhlau, 1996), 151; Franz Machilek, "Der Olmützer Humanistenkreis," in Der polnische Humanismus und die europäischen Sodalitäten, ed. Stephan Füssel and Jan Pirozyński (Wiesbaden: Harrassowitz, 1997), 114f.

19 Ivo Hlobil, “K diskusi o Stanislavu Thurzonovi (1471-1540)," Historická Olomouc IX. Tématický sborník př́spěvků zaměřných k otázkám prolínání renesance a humanismu do českých zemí, zoláště na Moravu a do Olomouce, 1992, 51; Vojtěch Cekota, "Z názorů olomouckých humanistů v první polovině 16. století," Studia Comeniana et historica 13, No. 26, 1983, $163 f$. 
to the wider Central European scholarly network until 1497 when Stanislav Thurzo was appointed to the Olomouc episcopal chair. Thanks to his reforms, intellectual traffic could emerge in Olomouc, when the bishopric and two chapters stood in for a regional aristocratic court. As a consequence, there was major interaction with the Viennese court and subsequently the transmission of Celtis's intellectual projects to Moravia. Here Augustinus was considered the crucial agent, the one who was in direct contact with Celtis himself and experienced the model of sodality interaction in Buda. From this point of view, also his works (such as Catalogus episcoporum) are interpreted as a direct part of the Germania illustrata project.

In Wörster's approach, the existence of a sodality of scholars in Olomouc is of particular importance. The dispute about the name of this sodality is in itself symptomatic. While the Czech literature uses the name Societas Maierhofiana (following the humanist K. Apitius, whose membership, like most other information on the sodality, we cannot prove), German-speaking scholars use the term Societas Marcomannica. According to Wörster, thirteen out of twenty-eight humanists active in Olomouc in the time of Thurzo's bishopric studied at Vienna University directly under Celtis's guidance; another ten probably spent some time there between 1497 and $1508 .{ }^{20}$ Augustinus probably also had earlier experience with a model of scholarly cooperation in the context of the sodality, because when he was ViceChancellor at the Buda court he attended meetings of the Sodalitas literaria Ungarorum, which coincidentally broke up shortly after his return to Olomouc.

Letters describing Celtis's alleged second journey to Olomouc in 1504 refer to a local humanists' promise to send a map of Moravia, a versed description of the bishop's city and an appropriate passage to the planned Germania illustrata, which would contain a description of the region Marcomannia (coinciding with the territory of Moravia). According to Wörster, the no longer extant work from the 1490s De origine, moribus et vestitu Hannatarum was also supposed to have originated under the influence of Celtis's project. ${ }^{21}$ Its author Konrad Altheimer, arch-deacon of the Olomouc Chapter and de facto representative administrator, tried to describe, apparently on the basis of inspiration from Tacitus' Germania, the origin and customs of the inhabitants of the Haná region whom he identified with Henets (Veneds). Another one is a historical work about the Olomouc bishops, Catalogus Episcoporum Olomucensium by Augustinus Olomucensis published in 1511 in Vienna. It is rather a rewriting of a work from the 1430s, with an emphasis on the historical uniqueness of the Moravian bishopric, the independence of the

20 Wörster, Humanismus in Olmütz, 47f.

21 Wörster, Humanismus in Olmütz, 95. 
title of the Moravian king and the Marcomanni origin of the Moravian population. ${ }^{22}$

\section{Conclusion}

To sum up my paper, Augustinus is a telling example of a scholar whom modern historians represent as a crucial agent in the process of cultural transfer - in this case the transmission of humanistic civilisatory valuesmostly directly from Italy as its original centre into Moravia. In order to describe his civilising mission, modern historians had to - first of all-classify Augustinus as a humanist and not a medieval author. Although Augustinus's works "oscillated", as Jana Nechutová put it, "between humanistic writing and religious treatises", historians concentrated predominantly on his "pure" humanistic works, such as the Dialogus or his treatise on letter writing. ${ }^{23}$ For instance, his treatise against Waldensians was not edited until 1985. ${ }^{24}$ Historians also applied markedly similar figurative tools to express Augustinus's role as the apostle of the new age. From the 1890s onwards, the paradigm of civilisation influenced German-speaking historians, who developed the tradition of Landespatriotismus and tried to incorporate Moravia into the story of European intellectual progress. As far as the production of national identities is concerned, scholarly discussions addressed primarily the place from where Humanism was imported to Olomouc. All answers to this question - be it directly Italy, Vienna, Buda, Poland or "Slovakia" (i.e. Upper Hungary) or even the reduction of external influences - were used in the name of particular national communities. In the next step, Czech scholars of the interwar period paid special attention to Augustinus's ethnicity, so that they could connect his civilizing mission with the period's national efforts. Although these readings are still influential, the question is how future scholars should rewrite the history of Olomouc Humanism.

22 Peter Wörster, "Zwei Beiträge zur Geschichtsschreibung in Olmütz in der ersten Hälfte des 16. Jahrhunderts," in Studien zum Humanismus in den böhmischen Ländern, Bd. 17, Teil III. Die Bedeutung der humanistischen Topographien und Reisebeschreibungen der humanistischen Zeit bis Zeit Balbíns, ed. Hans-Bernd Harder and Hans Rothe (Köln, Weimar and Wien: Böhlau, 1993), 39f; Wörster, Humanismus in Olmütz, 152.

23 Augustin Olomoucký, Obrana básnictví 1492, ed. Jana Nechutová (Brno: Blok, 1987), 10.

24 Augustinus Olomucensis, "Tractatus de secta Vadensium," ed. Jana Nechutová and Magda Rösslerová, Sborník prací Filosofické fakulty brněnské univerzity, series E 30, 1985, 133-147. 


\section{APPENDIX ONE}

\section{Poems by Augustinus Moravus Olomucensis}

This chapter includes the poems written by Augustinus Moravus. All poems are published with classical orthography and modernised punctuation. Wherever possible, URL links to digital resources have been included to facilitate the access to primary sources.

\section{Selected bibliography}

Ábel, Jenő. "Magyarországi humanisták és a dunai tudós társaság." In Értekezések a Magyar Tudományos Akadémia Nyelv-és Széptudományi Osztálya köréból, VIII, 21-32. Budapest: Magyar Tudományos Akadémia, 1880.

Augustini Olomucensis Dialogus in defensionem poetices. Edidit Karel Svoboda. V Praze: Nákladem České akademie věd a uměni, 1948.

Bauch, Gustav. "Zu Augustinus Olomucensis." Zeitschrift des deutschen Vereins für die Geschichte Mährens und Schlesiens 8 (1904), 119-136.

Celtis, Konrad. Der Briefwechsel des Konrad Celtis, gesammelt, herausgegeben und erläutert von Hans Rupprich, Veröffentlichungen der Kommission zur Erforschung der Geschichte der Reformation und Gegenreformation, Humanistenbriefe, III. Bd. München: C. H. Beck, 1934.

Ekler, Péter. “'Epistolaris itaque formula attenuato stilo ducetur potissimum...' Az ideális stílusnem kérdése Augustinus Moravus Olomucensis De modo epistolandijában." In Convivium Pajorin Klára 70. születésnapjára, ediderunt Enikő Békés et Emericus Tegyey, 75-81. (Classica - Mediaevalia - Neolatina VI.) Societas Neolatina Hungarica, Sectio Debreceniensis; Institutum Doctrinae Litterarum Academiae Scientiarum Hungaricae. Debrecen-Budapest, 2012.

Gastgeber, Christian. Augustinus Moravus und seine Beziehungen zum Wiener Humanistenkreis. [See the article in the present volume.]

Kowalska-Urbankowa, Zofia. Mikołaja Rozembarskiego traktat z roku 1499 o pochodzeniu Tatarów: studium krytyczne i edycja traktatu. De Nicolao Rosembergio eiusque Explanatione compendiosa de situ, moribus et diversitate Sciticarum genitium anno MCDXCIX scripta. Kraków: Nakładem Uniwersytetu Jagiellońskiego, 1993.

Miggiano, Gabriella. “Galeotto Marzio da Narni. Profilo biobibliografico (II)." Il Bibliotecario 33-34 (1992): 93.

Olahus, Nicolaus. Hungaria et Atilla. Edited by Adam Franz Kollar. Vienna: Trattner, 1763.

Wotke, Karl. "Augustinus Olomucensis (Augustinus Käsenbrot von Wssehrd)." Zeitschrift des deutschen Vereins für die Geschichte Mährens und Schlesiens 2 (1898), 47-71. 


\section{Ad populum de anni oeconomis}

In: Augustinus Moravus, In annum Christi 1492 prognosticon. Venice, 1491. (GW 3059), fol. aii

Secondary literature

Bauch, "Zu Augustinus Olomucensis", 121.

\section{Ad populum de anni oeconomis ${ }^{1}$}

Nunc Cytherea suum felicius extulit astrum,

Cum Iove quae supero sceptra superba tenet.

Falcifer adversam vibret licet undique falcem.

Imperiis dominae ${ }^{2}$ flectitur ille tamen.

Liber ab Eois gravidis en ipse racemis

Advenit, et flavo caespite vincta Ceres:

Vos quoque ad obsequium dominae ${ }^{3}$ properantius ite,

Laetior hic vobis totus ut annus eat.

\section{2}

\section{Ad eundem epigramma}

In: Augustinus Moravus, In annum Christi 1492 prognosticon. Venice, 1491 (GW 3059), fol. [av]

Secondary literature

Bauch, "Zu Augustinus Olomucensis", 122.

\section{Ad eundem ${ }^{4}$ epigramma}

Qui patria virtute nites, gravitate Catonem

Exprimis, et Numam religione ${ }^{5}$ refers $^{6}$

economis ed. 1491

domine ed. 1491

3 domine ed. 1491

4 enndem ed. 1491. "Ad eundem": i. e. "Ad Andream Stiborium". Augustinus lost his father, Aegidius very early. Augustinus, however, received a very good education through his uncle on his mother's side, Andreas Stiborius (Ctiborius) the canon of Olomouc, who died in 1496. His name appears in different forms (Ctiborius-Stiborius) but he should not be confused with the Viennese scholar Andreas Stiborius (ca. 1470-1515).

5 relligione ed. 1491

6 The text shows parallels with István Báthory's (d. 1493) epitaph: “Qui curios vita vicit, probitate Catones // Aequavitque Numam, religione Dei: // Nam coluit verum prisca pietate tonantem...", cf. János Kalmár and Barnabás Szalontai, "A Báthoriak címeres kőemlékei," in 
Quo pietas fortisque manet constantia, virtus Integra, et antiquae nobilitatis honos,

Macte animo seu quum gravioribus unda procellis

Presserit, hostiles concieritque manus,

Accipe, et id nostri quam primum perfer ad aures

Principis, officii cura sit ista tui:

„Haec meus Ausoniis vates tibi mittit ab oris,

Plurima missurus, si valuisset, erat."

\section{3}

\section{Ad libellum}

In: Augustinus Moravus. Dialogus in defensionem poetices. Venice, 1493. (GW 3057), [fol. $1^{\mathrm{v}}$ ]

Secondary literature

Wotke, "Augustinus Olomucensis...", 54-55.

Edition

Augustini Olomucensis Dialogus in defensionem poetices, 11.

\section{Ad libellum}

I, liber, et nitidas celerem te confer ad arces

Praesulis, et docti principis ante fores!

Quid dubitas, ne te tetricae discrimina frangant

Turbae, vel rigidi probra supercilii?

An scombris tunicas renuis, thurique cucullos,

Pascere vel scabras sordidulus tineas?

An te difficiles remorantur cardine postes?

Nulla mora est, licet hinc officiosus eas.

Non est qui ignavos teneat foveatque clientes,

Gaudeat aut vastis turgidus agminibus.

Quin potius sanctos illic mirabere mores,

Nec, qui difficilem se tibi praestet, erit.

Verum ut sacratis primum tete vultibus offers,

Concidis et docti flaminis ante pedes,

Excipiet pronum castis amplexibus, inde

Perleget et docto proteget ingenio.

Dum tamen a sacris manibus tractabere, praesens

Ista velim memori pectore verba feras:

A Nyíregyházi Jósa András Múzeum Évkönyve 2 (1959), 69. We are grateful to Richárd Horváth for his helpful private communication. 
„Dant alii fulvi certatim dona metalli,

Gemmas et Tyrio vellera tincta fuco,

Concretas glacies Massylaque robora et orbes

Raraque Erythraei munera quaeque soli:

Iste perexiguo tibi me properavit honore,

Iussit et insignem nominis esse tui.

Quod licet exiguum testetur muneris auctor,

Addidit ast mentis pignora firma suae."

I, liber, et nitidas celerem te confer ad arces

Praesulis, et docti principis ante fores!

\section{4}

\section{De Veneris et Martis congressu hexastichon ad Vulcanum}

In: Augustinus Moravus. Iudicium anno Domini 1494. Rom, 1494. (GW 3060), fol. 3.

De Veneris et Martis congressu hexastichon ${ }^{7}$ ad Vulcanum

Mulciber occulta cur non retinacula nectis?

Prodis et incestos iam quoque concubitus?

Gradivus thalamos repetit, pulchramque Dionem,

Atque cupita ferus gaudia solus habet;

Sic nobis blandum Veneris comprimitur astrum.

Disturba incestas, Mulciber, insidias!

\section{5}

\section{Ad populum tetrastichon}

In: Augustinus Moravus. Iudicium anno Domini 1494. Rom, 1494. (GW 3060), fol. $6^{\mathrm{v}}$

$$
\text { Ad populum tetrastichon }{ }^{8}
$$

Fatorum seriem caelique volumina paucis

Explicui, miseri mortales discite, et iras

Has superum castis precibus placate: Manent haec

Certa quidem, sed quae superi tamen omnia versent.

7 hexasticon ed. 1494

8 tetrasticon ed. 1494 
In: Augustinus Moravus. De modo epistolandi. Venice, 1495. (GW 3058), fol. Diii $^{\mathrm{v}}$

Secondary literature and editions

Bauch, "Zu Augustinus Olomucensis", 126.

Ekler, " 'Epistolaris itaque formula attenuato stilo ducetur potissimum...' Az ideális stílusnem kérdése...", 75-81.

online: http://daten.digitale-sammlungen.de/ db/0003/bsb00039345/images/

\section{Ad librum}

Quo properas, tam parve liber? Quo pergis inepte?

Curque fugis vatis scrinia tuta tui?

An non tot nasos metuis? Tot denique ronchis

Naribus? Et tetricos tot tibi rhinoceros?

Qui simulac patulas audax captaveris auras

Teque feres turba praetereunte legi,

Te lacerent digitisque notent verbisque fatigent

Acribus, et putri te quoque dente petant.

$\mathrm{Si}$ sapis ergo cave calidae te credere turbae,

Nec nisi paucorum limina docta subi!

Grammaticos etiam fugies ludique magistros,

Haec tibi, crede mihi, turba nocere potest.

Nil istis levius, nihil est petulantius illis,

Utraque iudicio pestis acerba meo.

Sed properas monitusque tui perferre parentis

Negligis, audaci laberis atque pede:

I felix faveasque bonis, latrantibus "ite,"

Dixeris "impuri, longius ite, canes!"

\section{7 \\ Ad eundem}

This dedicatory epigram survives in the manuscript (Vienna, ÖNB. cod. 3482) of the De situ, moribus et diversitate Scythicarum gentium by Nicolaus von Rosenberg, the Polish envoy (orator) to the court of Emperor Maximilian I (1498).

In this epigram, Augustinus almost surely imitates the Laus Panonniae of Janus Pannonius ("Magna quidem nobis haec gloria, sed tibi maior, // nobilis ingenio, patria, facta meo"). 
Secondary literature

Ábel, "Magyarországi humanisták és a dunai tudós társaság”, 30.

\section{Editions}

Olahus, Nicolaus, Hungaria et Atilla, 201.

Kowalska-Urbankowa, Mikołaja Rozembarskiego traktat z roku 1499 o pochodzeniu Tatarów..., 67.

Augustini Moravi Olomucensis serenissimi Hungariae regis secretarii tetrastichon ad eundem ${ }^{9}$

Inter Sarmatiae proceres, Nicolae, refulges,

Nobilitate, opibus, viribus, ingenio,

Non ${ }^{10}$ patriae acceptum referens: sed plurima debet ${ }^{11}$

Sarmatia ingenio splendida facta tuo.

\section{8}

"Hic tibi, sed caute, praesentes collige flores"

Augustinus Moravus probably wanted to publish in Vienna the De incognitis vulgo of Galeotto Marzio (1427-c. 1497), a mostly theological and often heretical work of this Umbrian humanist, who often engaged in conflicts with church authorities. Augustinus's intentions might have been thwarted because of the "dangerous" contents of the book, a fact that is hinted at in this paratextual epigram.

Secondary literature

Ábel, “Magyarországi humanisták és a dunai tudós társaság”, 31.

Edition

Miggiano, "Galeotto Marzio da Narni. Profilo biobibliografico (II)", 93.

Hic tibi, sed caute, praesentes collige flores,

Neve animum subeant mixta venena, cave.

Nam passim invenies opobalsama iuncta cicutis,

Et mala Cecropiis toxica nexa favis,

Quae neque barbarici pellant medicamina regis,

Nec de Phasiacis gramina lecta iugis,

Sed Christi sincera fides, quam fallere quavis

Arte vel ingenio fraus inimica nequit.

9 i.e. Nicolaus Rosenberg

10 Hoc ed. 1763

11 debet ed. 1763; debes ms. 
9

[Ad Conradum Celten]

(Vienna, about 1497)

Secondary literature

Ábel, "Magyarországi humanisták és a dunai tudós társaság”, 30.

Bauch, "Zu Augustinus Olomucensis", 126-127.

Rupprich, Der Briefwechsel des Konrad Celtis, 300-301.

For this poem most recently, see the article by Christian Gastgeber in the present volume.

\author{
Augustinus Olomucensis ${ }^{12}$ regis Pannoniae secretarius ${ }^{13}$ \\ Celtis Pegaseas sacro ex Helicone Camoenas \\ Vexit ad Austriaci rura beata soli. \\ Salve igitur, Phoebi criniti sancte sacerdos, \\ Celtis, Germanae gloria rara ${ }^{14}$ togae, \\ Et vos laurigerae, cultissima turba, sorores, \\ Tu quoque inaurata, pulcher Apollo, lyra. \\ Quae vobis genitus Morava gente poeta \\ Carmina dat, tenui sint licet orsa modo, \\ Perpetui, quaeso, sint vobis pignus amoris. \\ Haec sint parva licet, mens pia magna facit.
}

10

Threni neglectae Religionis ad Vladislaum Pannoniae Boemiaeque regem invictissimum

In: Sebastiano Giustiniani, Oratio magnifici et clarissimi d. Sebastiani Iustiniani oratoris Veneti ad serenissimum dominum Vladislaum Pannoniae et Bohemiae regem. Leipzig, 1500. (GW M15600), fol. B2 ${ }^{\mathrm{v}}-\mathrm{B} 3^{\mathrm{v}}$.

online: http://diglib.hab.de/inkunabeln/202-69-quod-1/start.htm

Augustinus doctor: Threni ${ }^{15}$ neglectae Religionis ad Vladislaum

Pannoniae Boemiaeque regem invictissimum

Regia progenies, genus alto ex sanguine divum, Ardua cum virtus pectore fixa manet,

\footnotetext{
12 Olomocensis Ábel, 1880; Rupprich, 1934

13 Re. Pann. Secr. Ábel, 1880; Re. Pan. Sec. Gastgeber, 2015

14 magna Bauch, 1904

15 treni ed. 1500
} 
Cui quoque sacrato fulget clementia vultu, Candida simplicitas, inviolata fides.

Ingenium Pallas, validos Bellona lacertos

Cui dedit, et gratum Cynthius eloquium,

Iuppiter ast artes pacis, Mars horridus arma

Pictaque victrici signa referre manu.

En ego, quae totum fueram celebrata per orbem,

Religio illa parens intemerata deum,

Regibus imperitans terraque marique verenda,

Culta fide aëreis sic quoque vecta plagis,

Sub iuga Hyperboreos populos, Rhodanumque rapacem,

Argolicos revocans per freta longa duces,

Eridanum Tiberimque, Tagum Meroemque, Niphatem, ${ }^{16}$

Undeque ${ }^{17}$ septena Nilus oberrat aqua,

Pulsa vagor propriis regnis latumque per orbem,

Vix datur in certo conquievisse loco.

Sic modo (proh superum pietas) neglecta per omnes

Gentesque et populos dilanianda feror,

Quaeque olim invictos reges moderabar et urbes,

Exul in ignotas hospes oberro domos,

Tristibus aerumnis lacrimans sparsisque capillis,

Horrida et iratis unguibus ora notans.

Heu mihi, nam vasto me barbarus hostis in orbe

Persequitur, miris conficit atque modis.

Nec superest de tot peragrati partibus orbis,

Qua ${ }^{18}$ mihi stet rutum posse referre pedem ${ }^{19}$ :

Graecia nam capta est, capta et Nabatheia regna ${ }^{20}$

Atque Amphionia moenia structa Chely ${ }^{21}$,

Assyriae segetes, Pactoli ${ }^{22}$ nobilis unda,

Hinc Solyma ${ }^{23}$, et quicquid dives Iduma ${ }^{24}$ tenet,

Caelicolum spoliatur honos. Pia numina ${ }^{25}$ Christi

Ipsaque populis iura verenda dabam.

Ridemur superum, Mahumet properantur honores

Et recutita ${ }^{26}$ pubes iam prope cuncta tenet:

Sive hoc ira deum fatique volubilis ordo,

Seu peperit numini - proh - scelerata fames,

16 Nyphatem ed. 1500. Cf. Vergil, Georg. 3, 30; Horace, Carm. 2, 9, 20.

17 undique ed. 1500

18 Quia ed. 1500

19 cf. Propertius, 3, 15, 14. "Nescit vestra ruens ira referre pedem."

20 i.e. Arabia

21 i.e. Thebes

22 The River Pactolus, cf. Horace, Epod. 15, 20; Pliny the Elder, Nat. Hist. 5, 110; Solinus, 40, 10.

23 Hierosolyma (Jerusalem)

24 Palestine, cf. Lucan, 3, 216; Valerius Flaccus, 1, 12.

25 numima ed. 1500

26 retutita ed. 1500 . The word 'recutita' is likely to refer to circumcision. Cf. Tertullian, $A d$ nationes, $1,14,1$. 
Ipsa igitur tanto sub pondere fessa malorum

Maesta parens quam sim, Vladislae, vides?

En matris ${ }^{27}$ miserere tuae, grata ubera primum

His manibus quondam quae tibi praestiteram,

Te quoque fonte sacro lotum lustralibus undis

Tot tandem populis imperitare dedi.

Forsitan ignotos vultus miraris, et ora

Atque habitus, laceras horridulasque comas

Membraque tam vario tenuata errore viarum,

Hospita dum terris profuga facta feror.

Barbarus heu Turcus solitos mihi ademit honores

Et laceram, ut cernis, carpere iussit iter.

Hinc matris miserere, precor, miserere tuorum,

In praedam totiens quos ferus ille trahit.

Hoc Christus iubet ipse tuus, iubet arbiter orbis,

Hic modo, qui Romae moenia celsa tenet.

Cernis, ut invicto procedat robore Gallus

Hunc contra socia et iungere signa parat?

Adriaco Veneti mittunt et $a b$ aequore patres

Atque tua exposcunt prospera vela sequi,

Insignes pietate viri, quorum inclita virtus

Dexteritasque animi cognita saepe fuit,

Nunc terraque marique prement, huic classe potenti

Incumbent ${ }^{28}$. Tardas tu modo rumpe moras,

Tu modo rumpe moras, quaeso, tunc ${ }^{29}$ auspice Christo

Te duce iam tandem ${ }^{30}$ barbara turba cadet.

Telos

Augustinus doctor

11

Eiusdem Augustini decastichon

In this paratextual epigram, Augustinus warns his readers to follow the examples of the good bishops of his diocese, and not to be influenced by the life of Bavarus and Mrazo, whom Augustinus blamed with sacrilege and gluttony.

27 matrix ed. 1500

28 intumbent ed. 1500

29 tuamque ed. 1500

30 tamdem ed. 1500 
In: Augustinus Moravus. Catalogus episcoporum Olomucensium. Vienna: Hieronymus Vietor, Johann Singriener, d. Ä., 1511. (VD16 K 8), fol. A2v

Secondary literature

Rothkegel, Martin. Der lateinische Briefwechsel des Olmützer Bischofs Stanislaus Thurzó: eine ostmitteleuropäische Humanistenkorrespondenz der ersten Hälfte des 16. Jahrhunderts. (Hamburger Beiträge zur Neulateinischen Philologie), Münster: LIT Verlag, 2007, 64-65., 101-104.

Wörster, Peter. Humanismus in Olmütz. Landesbeschreibung, Stadtlob und Geschichtsschreibung der ersten Hälfte des 16. Jahrhunderts, 145-155. (Kultur- und geistesgeschichtliche Ostmitteleuropa-Studien; Bd. 5), Marburg: N. G. Elwert Verlag, 1994, 145-155.

\section{Edition}

Augustini Olomucensis episcoporum Olomucensium series, quam recensuit, continuavit, notisque historico-chronologicis illustravit Franciscus Xav. Richter, ss. theologiae bacalaureus, historiae universalis professor emeritus, nunc Caesareo-Regiae Universitatis Olomucensis bibliothecarius et archiepisc. consist. consil. tit. Olomucii: characteribus Aloysii Skarnitzl, 1831, XIV.

\section{Eiusdem Augustini decastichon}

Clauditur hoc parvo series numerosa libello

Pontificum, per quos gratia larga venit

Christicolis ${ }^{31}$, quis sancta fides et mysticus ordo

Hoc numero (ut cernis) sacra regenda dedit.

Nec te vel Bavarus moveat, vel Mrazo prophanus, ${ }^{32}$

In spinas flores degenerare solent.

Illorum potius mireris candida facta,

Quos decorat priscae religionis honos,

Nam vitae meritis redolet fulgetque beatque,

Vilescit vitiis pontificalis apex.

31 Cristicolis ed. 1511

32 Bavarus (Jan/Johannes V. Bavor, bishop of Olomouc: 1199-1201) and Joannes Mraz (Jan XI. Mráz/Mrazo, bishop of Olomouc: 1397/1398-1403) were two bishops who were blamed with sinful behaviour (gluttony and sacrilege) by Augustinus. 


\title{
Valentin Eck's Panegyricus in Honour of Augustinus Moravus Olomucensis
}

\author{
(Cracow: Florian Ungler, Wolfgang Lern, [1513])
}

To the best of our knowledge, Valentin Eck's poem has not been published in a modern edition yet. In 1898 Karl Wotke issued a section of the work originally printed around 1513. Surviving copies of the Panegyricus seem to be extremely rare (three copies are known: Kraków, Biblioteka Jagielońska, Cim. 5538; Wrocław, Ossolineum, XVI. Qu. 3593 and Strängnäs, Cathedral Library, Q. 304, the last originally from the Jesuit College of Olomouc).

Although the poem is not written by Augustinus himself, the rich contents and the rare availability of the original print seem to justify its inclusion to our volume.

Valentin Eck (ca. 1494-1556) was born in Lindau (South Bavaria). He studied in Leipzig in 1508, together with Rudolf Agricola Junior. He moved to the University of Cracow in 1511. Eck left Cracow in 1517 and accepted the post of headmaster at the town school of Bártfa (Bartfeld, Bardejov).

The Panegyricus in laudem Augustini Moravi (published in Cracow: Florian Ungler, Wolfgang Lern, 1513) is a unique source about the learning and cultural interests of Augustinus Moravus, written by Valentinus Eck, the young Bavarian humanist, probably during his sojourn in Olomouc in 1510 or 1511 as a guest of Augustinus. This panegyric of 285 lines praises the Moravian scholar and his library, and gives a detailed account of the humanistic group that was formed around Augustinus in Olomouc. Eck's description of Augustinus's library, which included a number of classical and post-classical authors (books of the Greek Stoa, the Old and the New Testament, Homer's Iliad and Odyssey, Lucan, Statius, Silius Italicus, Ovid, Paulus Orosius, Florus, Fulgentius the Mythographer, Livy, Dionysius of Halicarnassus, Isidore of Seville, Quintilian, Justinian; and his verses resemble Tibull's, Virgil's and Cicero's writings), is a particularly precious source, as it provides a telling proof of his cultural and literary preferences, as well.

Eck prefaced the main work with a dedicatory letter to Sigismund Glotzer, and inserted a brief panegyric verse to him following the main work. He ended the book with a short poem in honour of Johannes Tulner, the vicarius of Olomouc. In his letter to Sigismund Glotzer, Eck praises the canon for his 
learning and his virtues and asks him to accept the gift of his poem written in honour of their common patron, Moravus. ${ }^{1}$

We are grateful to the Wrocław Ossolineum for making the full text of the print (XVI. Qu. 3593) available to the National Széchényi Library free of charge and giving permission for publishing the full text. The poem and the texts preceding and following it are given in classical orthography.

\section{Secondary literature}

Truhlář, Josef. Humanismus a humanisté v Čechách za krále Vladislava II. (Rozpravy Č. Akademie Fr. Josefa, III. 3. 4.) V Praze: Č. Akademie Fr. Josefa, 1894, 180-181.

Wotke, Karl. "Augustinus Olomucensis (Augustinus Käsenbrot von Wssehrd)." Zeitschrift des deutschen Vereins für die Geschichte Mährens und Schlesiens, 2 (1898), 61-64.

Glomski, Jacqueline. Patronage and Humanist Literature in the Age of the Jagiellons. Toronto: University of Toronto Press, 2007, 104, 107-108.

Valentini Eckii Philyripolitani panegyricus in laudem praestantissimi viri doctoris Augustini Moravi praepositi Olomunczensis et Brunnensis, necnon Pragensis atque utriusque ecclesiae Vratislaviensis canonici editus ${ }^{2}$

Magistri Ioannis Solfa ${ }^{3}$ ad Valentinum Eckium carmen Phalaecium ${ }^{4}$

Cur blandos retices amice versus,

Describis quibus optimi patroni,

Virtutes celeberrimas abunde?

Non sunt, quos metuas, amice, ronchi,

Non sunt rhinocerotici furores,

Non sunt lividulae gravesque sannae,

Augustine, decus peritiorum,

Fotor Palladiae pius catervae,

1 Jacqueline Glomski, Patronage and Humanist Literature in the Age of the Jagiellons (Toronto: University of Toronto Press, 2007), 104, 107-108.

2 aeditus ed. 1513

3 On Johannes Benedicti Solfa (1483-1564), see Aleksander Birkenmajer, "Prelekcja wstępna Jana Solfy z r. 1513," in Archiwum Komisji do Badania Historii Filozofii w Polsce, t. 2. (Kraków, 1921), 162-169; Waldemar Koźuszek, Jan Benedykt Solfa, lekarz polskiego odrodzenia (Wrocław: PWN, 1966); Tomasz Jaworski, “Jan Benedykt Solfa (1483-1564): humanista, nadworny lekarz ostatnich Jagiellonów," In Ludzie Środkowego Nadodrza: wybrane szkice biograficzne (XII-XX wiek) (Zielona Góra: Wydaw. „Verbum”, 1998), 190-193.

4 phaleutium ed. 1513 
Quam tu muneribus tuis honestas.

Non torrens Fabii loquela docti,

Non vis maxima Caesaris benigni,

Succincto Menelaus aut labello,

Nestor suaviloquo tuum palato

Quiret dinumerare, et hunc, et illum

Partum continuo labore, nisu

Fulgorem ${ }^{5}$ nitidum, novum aut vetustum.

Has laudes numeris tamen ligatis

Vultu suspicias, precor, sereno.

Valentinus ${ }^{6}$ Eckius Philyripolitanus clarissimo viro Sigismundo Gloczer ${ }^{7}$ canonico Olomuncensi s. p. d.

Cogitanti mihi cui potissimum amicorum has meas primitias nuncupatim ascriberem, subque eius tutela atque praesidio in lucem ederem ${ }^{8}$, occurristi tu omnium primus observandissime Sigismunde, cui hoc quantulumcunque opusculum probatum iri minime dubitavi. Propterea quod te in lectitandis poetarum carminibus et studiosum atque avidum cognoscerem, tum etiam quod pro comperto habeam compluscula cuiusvis facultatis monumenta hac potissimum de causa a multis saepius legi, quia viris et litteratis et prudentibus omnique virtute praeditis sint dedicata. Quis enim ignorat omne virtutum decus in te et splendere, et enitescere? Quippe qui Isocratis iucunditatem, Caesaris pulchritudinem, Demosthenisfacundiam, Antigonis mansuetudinem, Titi comitatem, Traiani iustitiam, et (ut caeteros volens praeteream) Cyri liberalitatem rite possideas, quoniam multis et praeclaris virtutibus undequaque es circumsaeptus, quae admissae (veluti apum examen ${ }^{9}$ redolenti thymo) in sacro tuo pectore residunt, quae mihi amplam atque divitem scribendi materiam suggererent, atque iustum volumen copiose admodum implerent, si evagari me in extollendis tuis virtutibus vel ingenioli mei teneritudo permitteret, vel ingenuus pudor tuus. Hoc tamen unum addidisse non verebor, tibi omnium virtutum ianuas ${ }^{10}$ esse apertas, quia in te mansuetudo, facilitas, modestia atque munificentia adeo indissolubili ${ }^{11}$ vinculo conglutinatae sunt, ut nulla illarum virtutum ab altera quibuscumque adversitatibus segregari queat. Sed quid plura? quoniam tuarum virtutum

5 Perhaps fulgentem, ?

6 Valetinus ed. 1513

7 Siegmund Glotzer, canon of Olomouc, born in Siebeneichen. He was the executor of Moravus' last will. See Glomski, Patronage..., 104.

8 aederem ed. 1513

9 axamen ed. 1513

10 ianuuas ed. 1513

11 iudissolubili ed. 1513 
praeconia aliubi enarrare institui, ergo inpraesentiarum ${ }^{12}$ Lacones potius quam Atticos insequar.

Quare, dignissime vir, te maiorem in modum rogo, ut hunc libellum (qui communis $^{13}$ nostri patroni laudes non plene et amplo, ut aiunt, ore, sed vix titulo tenus attingit) hilari vultu serenaque fronte suscipias! Munusculum est parvum et gracile, sed certe affectu grande, quod nostrum haud dubie amorem tanquam glutino tenacissimo indissolubiliter innodabit. Dii itaque faxint, ut istud sit perpetuum pignus ac monumentum meae erga te observantiae. Vale et me beneficentissimo amplissimoque et nunquam sine honoris titulo a me nominando, doctori Augustino Musarum Musiphilorumque patrono liberalissimo plurimum commenda. ${ }^{14}$ Iterum vale. Gracchoviae ex Germanorum contubernio VI. Idus Augusti.

\section{Valentini Eckii Philyripolitani panegyricus in laudem eminentissimi doctoris Augustini Moravi conditus}

\section{Praefatio}

Regia si mecum, vir quam celeberrime, dona

Pondero, quae tribuit dextera docta mihi,

Nulla potest tantum molis perferre statera,

Iusta hoc si saltem lance probatur onus.

$\mathrm{Si}$ vero ingenuos nitor depingere honores

Te quibus efflictim, ${ }^{15}$ doctor opime, colo,

Nulla voluntati est similis (mihi crede) papyrus,

Pectoris affectum qua reserare queam.

Si vero meritas intendo psallere laudes,

Gloria mortalis displicet usque tibi.

Non petis et nequeo rubro de littore conchas

Donare, aut gemmas, aurifer Herme, tuas.

Hoc igitur laeto parvum, rogo, pectore carmen

Suscipe, Thespiadum fautor amice domus.

Dent alii fulvum Pactoli ${ }^{16}$ ex gurgite munus

Aut Tyrio infectos murice rite sinus

Indica vel donet ${ }^{17}$ quod habet formica metallum,

12 inpaesentiarum ed. 1513

13 comunis ed. 1513

14 comenda ed. 1513

15 efflictim: cf. Plautus, Casina, prol. 49, Apuleius, Asinus aureus, 5, 6, 7.

16 Interestingly, Augustinus had mentioned the River Pactolos earlier in his poem entitled Threni neglectae religionis (1500). It is also noteworthy that later Eck also wrote a poem entitled Threni neglectae religionis (1518). Eck is likely to have been familiar with Augustinus's Threni.

17 Pliny the Elder, Nat. Hist. 11, 36, 111, "Indicae formicae cornua Erythris in aede Herculis fixa miraculo fuere. Aurum hae cavernis egerunt terra in regione septentrionalium Indorum, qui Dardae vocantur." 
Mygdonio cuius marmore ${ }^{18}$ tecta nitent.

Ast ego, quos fructus ardenti Iulius astro

Produxit, dono, vir generose, tibi,

Quos nunc pacato, vir quam doctissime, vultu

Suscipe, dona tibi mox meliora dabo.

Non etenim poterant rutilo sub sidere ${ }^{19}$ Cancri

Candida de nostro lilia rure dari.

Nam decus omne novi coxerunt fortiter agri

Saeva Molorchaei ${ }^{20}$ sideris $^{21}$ astra modo.

Hos etenim nostro flores decerpsimus agro

Dum nimium rapidus tunderet arva Canis ${ }^{22}$,

Quomque Leo ignivomis saeviret rictibus ardens,

Et Procyon saevas funderet ore faces,

Tempore quo fontes siccantur, et arva liquore

Privantur, Cererem et messor in arva petit,

Fasciculos avidus Corydon quo tempore largos

Colligit, hiberno ${ }^{23}$ ut tempore vivat ovans.

Sed me dentata segetes abscindere falce

Sidera $^{24}$ vulnifici prohibuere Canis,

Nanque adeo exussit nostros calor invidus agros,

Ut nullo flagrans flore nitescat humus.

Quare age combustos placido nunc pectore flores

Accipe, in autumno dulcia vina dabo,

Quom mea rorifero complentur rura liquore,

Et placidum accipient arvula nostra favum. ${ }^{25}$

Tuncque tibi Lesbi mittam de collibus uvas,

Et de Cretaeo donula monte feram. ${ }^{26}$

\section{Panegyrici initium}

Hactenus exiguo contentus carmine mentes

Traiectas Gnidia modulatus arundine, parvo

Versiculo ac molli diversa epigrammata buxo,

18 Ovid, Heroides, 15, 142. "Quae mihi Mygdonii marmoris instar erant."

19 sydere ed. 1513

20 Molorchus was a vine grower in Nemea, who received Hercules as his guest on his way to killing the Nemean lion. Hence, the Molorchaeum sidus is the zodiac sign of Leo.

21 syderis ed. 1513

22 'Canis': name of a constellation, referring to the time of Canicula.

23 hyberno ed. 1513

24 sidera ed. 1513

25 savum ed. 1513

26 seram ed. 1513 
Sed nunc tempus erit graviori insurgere cantu

Et de fluctifrago trepidantem pellere navem

Litore et antennis validas firmare triremes,

Ex quo doctiloqui celebranda est gloria vatis,

Cui chorus Aonidum famulatur, et alta Maronis

Buccina, Parnassi nemus ac memorabile collis.

Sed mihi Chrysocomi ${ }^{27}$ iam non pia numina divi

Sunt tentanda, ratem placido quom flamine nostram

Phoebaeus flectit vates Olomuntius, unus

Qui mihi Tiphys ${ }^{28}$ erit, Palinuro ${ }^{29}$ doctior. Ergo

Musa refer (quamvis magno haec dicenda Maroni

Smyrnaeoque ${ }^{30}$ forent) quae sit modo gloria vatis,

Culta Moravini quem fausto sidere ${ }^{31}$ rura

Progenuere agri castae de ventre parentis.

Urbs est ingenti disiungens pondere silvam ${ }^{32}$

Hercyniam $^{33}$ Austriacis foelix Olomuncia ab oris,

Hic ubi cum triplici circundat flumine clarum

Urbis opus ${ }^{34}$ Mora spumantem lapsurus ad Histrum, ${ }^{35}$

Quem fama est sacras olim coluisse sorores

Et per Marcomanum campos fudisse liquores

Gorgoneos ${ }^{36}$, quondam ceu per Boiontia ${ }^{37}$ passim

Rura Medusaeo fuderunt gurgite lymphas.

Hic, inquam, puerum gravida quom bellula mater

Phoebaeum ex alvo fudit, mox culta sororum

Turba novenarum ${ }^{38}$ sua crura manusque ligarunt

Fasciolis, veluti dicunt strinxisse poetam

Mercurio genitore satum nymphaque, nitentis

Quae coeli cursus vario modulamine signat.

Hic etiam fama est Charites cunabula circum

Proiecisse rosas, violis ac gramine molli

27 i.e. Apollo

28 the helmsman of the Argo ship, cf. Vergil, Eclogae, 4, 34. Ovid, Heroides, 6, 48. Valerius Flaccus, $2,390$.

29 the helmsman of Aeneas's ship, cf. Vergil, Aeneis, 5, 871; 6, 337-341.

30 Smyrna: a celebrated maritime city of Ionia; according to some, the birthplace of Homer.

31 sydere ed. 1513

32 sylvam ed. 1513

33 Herciniam ed. 1513

34 something that is the size of a town, cf. Vergil, Aeneis, 5, 119; Ovid, Fasti, 6, 643; Statius, Silvae, $2,2,31$.

35 Hystrum ed. 1513

36 Gorgonęos ed. 1513

37 Baeontia ed. 1513

38 nouennarum ed. 1513 
Obdurum stravisse solum, texisse coronam, Laureolam capiti et pueri imposuisse novelli, Oscula et ingenuis multum impressisse labellis. Hinc est, quod graciles dum vix sua labra loquelas Reddebant, vanos coepit contemnere ludos, Quos iuvenes ardent primis tractare sub annis, Ligneolo placuit nec tunc equitare caballo,

Sive Morae per aquas tumidi meditarier altas Piscibus insidias lento tunc vimine inanes, Alta per Hercynii placuit nec rura sagaces Hortari catulos nemoris. Nam praeda volucrum Et quicquid Sophiae iuvenes deflectit ab arce, Ingratum: eximium teneris vergebat in annis Doctrinae ad culmen, rudibusque elementa figuris Sculpta affectabat manibus tractare tenellis, Ac eadem bibulis cupiens inarare bacillo, Pulveribusque notas passim formare rotundas Coeperat, et si quos priscorum forte libellos Occlusos reperit vatum, reserare solebat Atque per ignotos rudibus discurrere labris Codiculos, veluti infantes ${ }^{39}$ persaepe videmus Non intellectis verba effutire labellis.

Sed postquam maior successit temporis aetas, Et sua vocali resonabant pondere labra, Mox laeto gravitas illuxit in ore senilis, Ingeniumque novis maturum splenduit annis, Atque verecundos lustrabat bellula vultus Gratia, purpureo et regnabat in ore venustus Et lepor et gravitas, veluti splendere rosetis Paestanis ${ }^{40}$ aiunt graciles floresque rosasque. Sed ne tam claro virtus in corpore abesset, Cirrhaeus ${ }^{41}$ flexit Musarum ad culmen Apollo Cor iuvenile, simul Sophiae instigavit ad artes Inde per antiquae duxit rarissima Dirces Regna, ubi sternacis monstri gravis ungula quondam Gorgoneos rupit fontes sacrosque liquores: Hic sua lustrali madefecit gurgite labra.

Illico multisonis coepit sufflare Camoenas

Vocibus, et streperam suavi ore implere monaulon ${ }^{42}$,

39 insantes ed. 1513. cf. Janus Pannonius, Panegyricus in Guarinum, 40-47.

40 cf. Vergil, Georg., 4, 119; Propertius, 4, 5, 61; Ovid, Metam., 15, 708; Martial, 5, 37, 9; 12, 31, 3.

41 Cyrrhaeus ed. 1513

42 Martial, 14, 64, 2. 
Haud secus ac Tyrias dulci qui carmine turres

Erexit vates, vel qui modulamine tigres ${ }^{43}$

Crudeles mulsit, gelidis ac rupibus Haemi

Frondosam evulsit bibulis radicibus ornum.

Hinc est, qui priscos potis est superare poetas:

Non tantum Ausonios, verum quos Graecia magnis

Laudibus astriferi coeli super astra locavit.

Nam sua non cedunt Smyrnaeo carmina vati,

Quamquam illum septem celebrarunt laudibus urbes

Multisonis. Certe sic sors tulit hunc generosa,

Ut Clarii a teneris pulsaret limina divi

Annis et tetricae studiis haereret opimis

Palladis, hinc duros perpessus saepe labores,

Atque aerumnali (nam sic petit ardua virtus)

Cum studio insomnes duxit noctesque diesque.

Immensis etenim celebres sudoribus artes

Gaudent, et duros sua dant ad culmina cursus.

Nunc ad Pierios fontes, et ad alta nitentis

Dogmata rhetorices vatumque poemata gressus

Flectebat celeres, Samii quoque clara parentis

Scripta tulit cupidis labris, ac caetera dona,

Vel quae Socratico manarunt flumine quondam,

Vel quae Stoa tulit, vel magna Academia libris ${ }^{44}$

Cecropiis sancto dederat modulamine quondam.

E quibus abstrusos sensus, praeceptaque sacra

Excerpsit, vegetasque acies infixit in omnes

Artes, degustans avidis documenta labellis

Omnia, quae prisci quondam docuere parentes,

Non aliter sapidi quam mellis provida nutrix

Arboream subiens vernali tempore silvam,

Singula purpurei depraedans germina veris

Iamque $^{45}$ rosas graciles, violas nunc flore rubentes

Delibans, donec castas impleverit alas,

Sic per Socraticas vates Olomuntius undas

Flectebat teneris gressus quoque pectora in annis,

Hinc est, quod nulli priscorum carmine vatum

Cedit, sed cunctos quotquot veneranda vetustas

Laudibus extollit, superat modulamine suavi.

Sic erat Andinus, sic blandi scriptor amoris

43 tygres ed. 1513

44 Valentin Eck imitated this part from Janus Pannonius's Panegyricus in Guarinum Veronensem, $172-175$, just like lines $44-55$ from the $40-51$ of the Guarino-panegyric.

45 ianque ed. 1513 
Paelignus, binis vel vates captus ocellis, Quem propter varium dicunt aenigma sagacem Spiritulum caecis Stygiae immisisse paludis Fluminibus. Talem veteres dixere Tibullum, Quom Nemesim facili laudavit carmine nympham, Sic etiam vates fuerat, cui Lesbia dulce Miscet opus, tenero qui scripsit carmine Amores ${ }^{46}$, Et cui lascivo toties pede, Cynthia, blandis Te modulis infers, et caeco corda poetae Igne premis; talem veteres dixere Melissum, Daedala cui flavi stipatrix nomina mellis Indidit; haud tantum micuit de sanguine vates Cretus Apollineo ${ }^{47}$, varios qui condidit alti Et Phoebi et Lunae cursus, quoque mystica lusit Dogmata coelesti multum placitura cohorti. Sed labor est tenui cunctos numerare poetas, Carmine quos superat, quando modulamine Phoebum, Eloquio Marcum, sancta virtute Catonem, Et probitate Numam, Crassum gravitate, loquela Mercurium, annosum prudenti Nestora corde, Ac pietate Titum, Traianum lance fideli Aequat. Nam variae virtutes corpore in uno Stipanturque viri circum praecordia, fulget Virtutum omne decus, quod raro in corpore pulchro Cernitur, et corvo virtus est rarior albo, Incolit ingenuos pulchri quae corporis artus. Ille etenim vates Olomuntius omnia servat Munera virtutum, nam magnus in ore redundat Et lepor et gravitas, excelsae et gratia fronti Tanta est, ut verbis satis explicare valebit Nemo hominum, superet magnum licet ore Maronem. Ardua nam probitas pulchre est coniuncta venustis Artubus, ac veluti si quando pulchra rosetis Lilia purpureis miscentur floribus, aut si Vina sub auratis resplendent Massica poclis, Plus dulcoris habent, ardorem vasa bibendi Incutiunt; nitido sic splendens corpore virtus Gratior esse solet, digna et cum laude perenni Vatibus extolli qui Phoebi dona frequentant. ${ }^{48}$ Sed quid plura cano, quid frustra extendo Camoenam,

46 a direct reference to Ovid's work, written in elegiac couplets

47 i.e. Orpheus

48 frequantant ed. 1513 
Quom sua quadrifido virtus sit notior orbe,

Quam poterit nostro dici modulamine parvo?

Nemo etenim ignorat, quantas virtute pararit

Divitias, ut nunc opibus superare Darium

Possit, et Attalicas iam longe vincere gazas,

Et quicquid Pactolus habet, Tagus, Hermus, Hydaspes,

Nam sibi tot census Cerealis rite quotannis

Slesia persolvit, necnon ferus incola saltus

Hercynii, dulci celebrisque Moravia Baccho,

Atque aliae multae gentes, tot pondera fulvi

Persolvunt auri certo pro tempore messis,

Quas vix ingenti possem memorare melodo.

Hinc est, quod Phrygio sua nunc cum marmore clara

Tecta reformantur, celsis ubi tollit in alta

Sidera verticibus splendens Olomuncia turres:

Ah, quam pulchra domus vivaci picta colore,

Qualem vix pinxit multum laudatus Apelles,

Ingenio cuius Paphiae formosa puellae

Corpora mortalem dicunt sumpsisse colorem!

Inclyta Lysippi taceat nunc signa vetustas,

Protogenisque simul tabulas, ac marmora gnavi

Praxitelis! Frustra iactat nunc Zeuxidis ${ }^{49}$ uvas

Graecia, Parrhasii velum, statuasque Myronis, ${ }^{50}$

Namque Augustini domus ardua fulta columnis

Marmoreis tales praesentat imagine formas,

Ut quis posse loqui credat, suspendere gressus

Atque movere modo, nec non imitarier ore

Sermones hominum, vivosque ostendere vultus,

Quae si pertenui vellem pictasmata ${ }^{51}$ metro

Enumerare, diem Phoebus depelleret orbe,

Antea quam possem summatim attingere cantu.

Hic etenim Herculeos admirarier ausus,

Quo modo Lernaeo mordax in gurgite pressa

Hydra sit, ac torvus Nemea regione Molorcho

Impulsore leo clava mactatus acerbe,

Vulnificus post haec longo certamine captus

Sus Erymanthaeis multum contrarius agris,

Et quo tergeminum vicit certamine regem

Geryonem, cuius Latias armenta per oras

49 Zeusidis ed. 1513

50 Mironis ed. 1513. For the Greek sculptors, see e.g. Pliny the Elder, Nat. Hist., 35, 36, 66 (Zeuxis), 67 (Parrhasius), 40, 133 (Praxiteles).

51 pyctasmata ed. 1513 
Egit ovans, post haec licet admirarier arcum, Laetiferum quo tunc traiecit viscera magna Stymphalidum, Libyae ${ }^{52}$ mox et quo Marte gigantem Obdura tellure satum demiserit Orco,

Aurea et Hesperidum depresso mala dracone Detulit ex horto victor, quo robore tandem Cerberon et Stygio custodem extraxerit antro. Omnia vivaci quae sunt pictasmate ${ }^{53}$ scripta, Atque alia excultis pulchre fabricata figuris, Scribere praesenti quae non modulamine possum,

Nam maior celebrandus erit thesaurus in aede, Quae scimus veterum ereptum de fonte virorum. Hic etenim latitant monumenta fidelia vatum, Quae de Cecropiis magno sunt tracta labore Fontibus, ac olim quae Stoa superba reliquit. Hic etiam libri latitant, qui pulchra duarum Dogmata suffundunt legum, sophiaeque liquores, Inclyta Smyrnaei latitant hic scripta poetae, Quae Danaum palmas resonant et Pergama bello Capta decennali, nec non errore maritum

Penelopes longo diversa per aequora ductum, Hic et Lucani perplexa poemata vatis Sunt, quae grandiloquo pandunt modulamine saeva Arma per Emathias turmas Macedumque phalanges, Aemulus Andini vocali carmine vates Statius armigeri hic claros super astra labores Aeacidis tollit, grandi quoque sidera cantu Pulsat et hinc vates magna, qui Punica voce Bella canit, Libyae ${ }^{54}$ nec non scelerata cohortis Facta, subit blandi Paelignus lusor amoris Corpora quo nullus Latiali carmine vates Aptius in varias cecinit mutata figuras. O felix vates Cypriae, ni caeca puellae Dogmata tam facili lusisses carmine, et aulam Caesaream tanto coluisses tempore, ab oris Ausoniis numquam Scythicum relegatus ad axem, Credo, fores, sed te forsan sic fata tulere, Ut nimium ardentes sentires pectore flammas. Sed quid plura loquor? Scripti genus hic latet omne, Quicquid in historia, sacris quoque legibus, altis 
Dogmatibus sophiae prisci cecinere parentes.

Hic etenim Paulus ${ }^{55}$ pandens ab origine mundi

Tempora nascentis, Florus, Fulgentius atque

Lacteus eloquii fons, ${ }^{56}$ hic est Livius, omnem

Historiae palmam merito qui vendicat ore

Romuleo, ${ }^{57}$ post hunc Dionysius ${ }^{58}$ arte disertus

Eloquioque potens, nulli sermone secundus

Veriloquo tandem flagrans Isidorus in arte,

Quintilianus item, doctus quoque Iustinianus.

Sed labor est tenui monumenta insignia vatum

Omnia nunc versu memorare et pandere cantu,

Quom sint hic propria vates Olomontius arte,

Quos dedit altisonis labris nitidisque Camoenis,

Qui redolent Phoebum, qui spirant arte Tibullum,

Nasonem sapiunt, referunt ac ore Maronem,

Et, quod praetereo, Ciceronem dogmate spirant.

Ergo te, celebris, cessa iactare, vetustas,

Atque tuos atavos vocali tollere in astra

Laude, quod ingentem veterum struxere librorum

Congeriem, nam docta tuos melioribus astris

Posteritas patres superat, maiora sequentis

Temporis extruxit nisus monumenta virorum,

Quamvis Romuleas Xerxes perduxit ad aedes

Priscorum quondam monumenta fidelia vatum,

Quae mox Argolicas modico non pondere ad oras

Rex Syriae (facta Romanis pace) reduxit,

Et quamvis Paulus superato rege superbo

Persarum Romam vexit generosa parentum

Scripta, quibus multum decorata est Martia sedes.

O felix, nimium felix Olomuntia, talem

Cui fortuna virum tribuit, qui Martia tecta

$\mathrm{Nec}$ non Argolicos ingenti rite penates

Thesauro veterum excellit de fonte virorum

Collecto! $\mathrm{O}$ felix genitor materque beata,

Qui tantum fausto genuistis sidere natum,

Quo duce nunc tamen florens Olmuntia crevit,

Ut iam consilio, iustis quoque legibus, omnem

Priscorum palmam teneat! Nam lege Solonem

Atque Numam superat, Mosen magnumque Lycurgum,

55 Paulus Orosius (c. 375-after 418 AD)

56 Cf. Hieronymus, Epistolae, (3) 53, 1. “T. Livium lacteo eloquentiae fonte manantem".

57 Rhomuleo ed. 1513

58 Dyonisius ed. 1513, i.e. Dionysius of Halicarnassus 
Ergo extende tuas cristas Olomuncia felix,

Atque superbificas extolle e pulvere laudes,

Quom tibi sit vates Traiano iustior, olim

Quem tamen celebres vatum cecinere libelli.

Ille tuus superat Gracchos ${ }^{59}$ virtute potentes

Ac probitate Titum, Crassum bonitate nitentem,

Nam dat divitias multis, ut vivere fausti

Rite queant, inopem pulchre et deducere vitam.

Ille poetarum fautor celeberrimus, omnem

Qui tollit maesta de sollicitudine mentem,

Unde suum crescit decus, et sua gloria vivet

Aeternum, nunquam Phrygios moritura per annos,

Et suus aethereas tandem migrabit ad aedes

Spiritus, et summi Paradisi gaudia cernet.

Hoc precor efflictim meritis ut tanta rependet

Dona suis supera Christus qui regnat in arce!

Eiusdem Valentini ad humanissimum virum Sigismundum Gloczer canonicum Olomunczensem, archidiaconum Znaimaviensem atque praepositum in Olberentzkirch. carmen Asclepiadeum ${ }^{60}$

Lesboum cupiens tangere barbiton

De, Sismunde, tua, vir celeberrime,

Virtute, Aoniis nescio quis iugis

Me pellit, quae mihi flumina denegat

Parnassi, reor hoc Pieridum deas

Attentare, tuas ne mea carmina

Defoedant nitidas voce protervula

Laudes, namque tuo pectore gloria

Ingens nunc residet, quae petit arduos

Smyrnaei modulos, Vergilii tubam

Et Flacci cytharam, sed mea, proh, dolor

Conspersit modico labra Polymnia

Cum rore, et tenues voce superbula

Condo versiculos, ergo piissime

Contentus modico vir, rogo, carmine

Sis nunc, mellifluo mox pede candidam

Virtutem trifidi per spatium soli

Divulgabo tuam. Nunc bene consule.

59 Grachos ed. 1513

60 For Gloczer, see n. 7. 


\section{Carmen Ioannis Lupuli Bodmanensis ${ }^{61}$ in Circumforaneum autoris obtrectatorem}

Torvo quid laceras, tu garrule, pectora vatis

Morsu? quid vexas haec rabidisque labris?

Tergemino laedis vatem ceu Cerberus ore,

Nec dubitas labris aspera ferre tuis.

Proh pudor! in faciem te dulcia verba proferre

Mortifera et dorso figere tela suo,

Thersitae merito similis sine mente locuto,

Et sensu, mordax, Tantalus alter eris.

$O$ prius insignem (teneris qui talia lusit

Anniculis) vatem considerato, precor.

Nam quater hic quinos nondum compleverit aevi

Autumnos, resonans quicquid Apollo tenet.

Quid senio, aut faciet Parcis ducentibus annos,

Ingenium vatis, quom iuvenile modo

Talia, tum tantae iam carmina scripserit artis,

Quae vix grandiloquus luserit ipse Maro?

Perspicuas molli et libantem Castalii ore

Fontis iam lymphas, Letifer, ipse sape.

Cuius Pieridum Daphnaea tempora lauro

Ornavit coetus, perfide, nosce virum.

Plus Maecenatem nunc horre temporis atque

In cuius laudes nymphula nostra fluit.

Hunc, quem fama patrem, virtus, titulique perennes

Quemque virum insignem docta Minerva canit.

Omnes quadrifidi huc accersit munere doctos

Mundi, perfugium iure vocantque patrem.

Atque suos celeri repetit pede turba penates

Doctorum, et laudem nunc sine fine canunt.

Desine vipeream nunc fundere pectore tabem,

Opprime nunc fauces, aut meliora fare. ${ }^{62}$

Aut stimulante modos reddet te musula iambo,

Flavus Apollo simul spicula figet eius.

61 Johann Wölfflin von Bodman (Johannes Lupulus Bodmanensis) has published a few paratexts in books printed in Cracow (e.g. Johannes a Lasco: Oratio ad Pont. Max. Leonem X in obedientia, Cracow, Ungler, 1513; Stephan Münzer (Monetarius) Cremnicensis, Epitoma musices, Cracow, 1515 - in which Eck published a poem, too, Stanisław Zaborowski: Orthographia, 1518). Wölfflin and Eck came from the same region (around the Bodensee) to Cracow.

62 The $2^{\text {nd }}$ person singular imperative of 'for, fari'. 
Eiusdem Valentini Ekii ad summae integritatis virum Ioannem Tulner vicarium Olomunczensem ${ }^{63}$ carmen Sapphicum extemporaneum

Hic benignorum solet esse vatum

Mos, Ioannes venerande, caris

Quom viris quicquam resonare dulci

Carmine tentant:

Aut canant magni generis parentes

Candidos, pulchri niveos vel artus

Corporis, laudent fragiles vel alto

Pondere gazas.

Sed quid imprimis dubius recensem,

Quom decus, virtus, honor et venustas,

Non inaequali tua corda luce

Iamque decorant.

Ergo ne tantum gracili decoris

Voce defoedam, reprimo Camoenas,

Donec infundet mihi plus canenti

Roris Apollo.

Ioannis Lupuli Bodmanensis ad sollertes artis impressoriae magistros Florianum Unglerium et Volfgangum Lern ${ }^{64}$ carmen extemporaneum

Croca fuit quondam gelido collata sub axe

Causa librorum saepe vitata viris.

At nunc huic laudem, decus ornatumque tulisti

Volfgange, insigni cum comite ipse tuo,

Illimis pulchro circumlita littera cultu

Non haec Aldinis cederet arte notis,

Non Iunonigenae ${ }^{65}$ tenuissima vincere nati

Stamina nunc possunt subtilitate notas.

63 Eck ended the book with a short poem in honour of Johannes Tulner, the vicar (vicarius) of Olomouc.

64 Lẹrn ed. 1513; Florian Ungler (?-1536) and Wolfgang Lern (15-16 ${ }^{\text {th }}$ cent.): printers in Cracow.

65 'Iunonigena': Vulcanus, cf. Ovid, Metam., 4, 173. Not even the finest threads made by Vulcanus can compare to the letter-types in subtlety. 



\section{APPENDIX THREE}

\section{Augustinus Moravus Olomucensis (1467-1513)}

\section{Selected Bibliography}

Contents

I) Texts

1. Primary sources. Old books. Printed editions

a) Augustinus's own independent works

b) Texts issued and published by Augustinus, and other publications that Augustinus contributed to

2. Modern textual publications

a) Publications of Augustinus's letters

II) Bibliography

1. Main studies, encyclopaedia entries, book chapters and sections, and further minor textual publications about the life and work of Augustinus

2. Further selected bibliography for Augustinus and his age

I) Texts

1. Primary sources. Old books. Printed editions

Abbreviations

GW = Gesamtkatalog der Wiegendrucke (http://www.gesamtkatalogderwiegendrucke.de/)

VD16 = Verzeichnis der im deutschen Sprachbereich erschienenen Drucke des 16. Jahrhunderts (http://vd16.de/)

a) Augustinus's own independent works

Augustinus Moravus. Dialogus in defensionem poetices. Venice: [Paul Friedenperger], 1493. (GW 3057)

Augustinus Moravus. De modo epistolandi. Venice: Simon Bevilaqua, 1495. (GW 3058)

Augustinus Moravus. In annum Christi 1492 prognosticon. [Venice: Johann Hamann, after 13 November 1491.] (GW 3059)

Augustinus Moravus. Iudicium anno Domini 1494. [Rom: Andreas Fritag, after 1 Januar 1494]. (GW 3060)

Augustinus Moravus. De secta Waldensium. Olomouc: Konrad Baumgarten, 1500. (GW 3061)

Augustinus Moravus. Catalogus episcoporum Olomucensium. Vienna: Hieronymus Vietor, Johann Singriener, d. Ä., 1511. (VD16 K 8) ${ }^{1}$

1 For further editions of the Catalogus, see Ralf Georg Czapla, "Augustinus Moravus," in Deutscher Humanismus 1480-1520. Verfasserlexikon, Bd. 1, A-K, herausgegeben von Franz Josef Worstbrock, 61-72. (Berlin, New York: De Gruyter, 2008), col. 68. 
Duplex confessio Valdensium ad regem Ungariae missa. Augustini de Olomucz ... epistolae contra perfidiam Valdensium. Eiusdem ... binae litterae ad regiam maiestatem de heresi Valdensium. Excusatio Valdensium contra binas litteras doctoris Augustini. Iacobi Zigleri ex Landau Bavariae contra heresim Valdensium libri quinque ... Leipzig: Heinrich Kuna, Melchior Lotter, d. Ä., 1512. (VD16 Z 442)

b) Texts issued and published by Augustinus, and other publications that Augustinus contributed to

Avantius, Hieronymus. Emendationes in Catullum et Priapea... Edited by Augustinus Moravus. Venice: Johannes Tacuinus, 1495. (GW 3098)

Blanchinus, Johannes. Tabulae caelestium motuum earumque canones. Edited by Augustinus Moravus. Venice: Simon Bevilaqua, 1495. (GW 4410)

[Augustinus Moravus.] "Threni neglectae religionis ad Vladislaum Pannoniae Boemiaeque regem invictissimum." In Sebastiano Giustiniani, Oratio magnifici et clarissimi d. Sebastiani Iustiniani oratoris Veneti ad serenissimum dominum Vladislaum Pannoniae et Bohemiae regem, fol. B2v-B3v. Leipzig: Wolfgang Stöckel, 1500. (GW M15600)

Augustinus Moravus. "Exhortatoria in impressionem tabularum astronomicarum Alfonsi Regis." In King Alphonse, Tabulae astronomicae, edited by Johannes Lucilius Santritter, fol. a2r. Venice: Johann Hamann, 1492. (GW 1258)

Antilogion Guarini et Poggii de praestantia Scipionis Africani et C. Iulii Caesaris, nuper doctissimi Augustini Moravi cura in lucem editum. Vienna: Hieronymus Vietor, Johannes Singrenius, 1512. (VD16 G 3856)

\section{Modern textual publications}

Augustini Olomucensis episcoporum Olomucensium series, quam recensuit, continuavit, notisque historico-chronologicis illustravit Franciscus Xav. Richter, ss. theologiae bacalaureus, historiae universalis professor emeritus, nunc Caesareo-Regiae Universitatis Olomucensis bibliothecarius et archiepisc. consist. consil. tit. Olomucii: characteribus Aloysii Skarnitzl, 1831.

Augustinus Olomucensis. "Tractatus de secta Valdensium", edited by Jana Nechutová and Magda Rösslerová, Sborník prací Filosofické fakulty brněnské univerzity. Řada E-archeologicko-klasická 30 (1985): 133-147.

Augustini Olomucensis Dialogus in defensionem poetices. Edidit Karel Svoboda. V Praze: Nákladem České akademie věd a umění, 1948.

Augustin Olomoucký. Obrana básnictví 1492. Edited by Jana Nechutová. Brno: Blok, 1987.

a) Publications of Augustinus Moravus Olomucensis's letters

Bohuslai Hassensteinii a Lobkowicz epistulae. Ediderunt Jan Martínek et Dana Martínková. Leipzig: Teubner, 1969-1980, tom. 2. Epistulae ad familiares, num. 42 (39-42.), num. 55 (67-68.)

Der Briefwechsel des Konrad Celtis, gesammelt, herausgegeben und erläutert von Hans Rupprich, Veröffentlichungen der Kommission zur Erforschung der Geschichte der Reformation und Gegenreformation, Humanistenbriefe, III. Bd. München: C. H. Beck, 1934. [301. (Nr. 180), 307-308. (Nr. 181), 311. (Nr. 184), 318. (Nr. 189), 322. (Nr. 192), 386-387 (Nr. 231), 566. (Nr. 313), 571-572 (Nr. 317), 575-576 (Nr. 320), 581-582 (Nr. 325), 582-583. (Nr. 326), 584-585. (Nr. 327).] 
Ábel, Jenő. "Magyarországi humanisták és a dunai tudós társaság." In Értekezések a Magyar Tudományos Akadémia Nyelv-és Széptudományi Osztálya köréból, VIII, 21-32. Budapest: Magyar Tudományos Akadémia, 1880. [110-111. (Nr. 1), 111. (Nr. 2), 111-112. (Nr. 3), 112. (Nr. 4), 112-113. (Nr. 5), 113. (Nr. 6), 113-114. (Nr. 7), 114. (Nr. 8), 114-115. (Nr. 9), 115-116. (Nr. 10)]

II) Bibliography

1. Main studies, encyclopaedia entries, book chapters and sections, and further minor textual publications about the life and works of Augustinus

Certain studies include poetry and other texts written by Augustinus Moravus. In these cases, the titles of Augustinus's works and texts are given in square brackets.

Ábel, Jenő. "Magyarországi humanisták és a dunai tudós társaság." In Értekezések a Magyar Tudományos Akadémia Nyelv-és Széptudományi Osztálya köréból, VIII, 21-32. Budapest: Magyar Tudományos Akadémia, 1880.

Augustinus Olomucensis. In Rukovět' humanistického básnictví v Čechách a na Moravě. Enchiridion renatae poesis Latinae in Bohemia et Moravia cultae. Založili Antonín Truhlář a Karel Hrdina. Pokračovali Josef Hejnic a Jan Martínek. Vol. I. Praha: Academia, 1966, 111-116.

Bauch, Gustav. "Zu Augustinus Olomucensis", Zeitschrift des deutschen Vereins für die Geschichte Mährens und Schlesiens 8 (1904): 119-136. [Ad populum de anni oeconomis, 121; Ad eundem [=ad Andream Stiborium] epigramma, 122; Augustinus's letter to Andreas Stiborius (in De modo epistolandi), 123-124.; Ad librum (in De modo epistolandi), 126; Ad Conradum Celten, 127.]

Bohuslai Hassensteinii a Lobkowicz epistulae. Ediderunt Jan Martínek et Dana Martínková. Leipzig: Teubner, 1969-1980, tom. 2. Epistulae ad familiares, 214-215.

Czapla, Ralf Georg. "Augustinus Moravus." In Deutscher Humanismus 1480-1520. Verfasserlexikon, Bd. 1, A-K, herausgegeben von Franz Josef Worstbrock, 61-72. Berlin, New York: De Gruyter, 2008.

Ekler, Péter. "Adatok Augustinus Moravus Olomucensis (1467-1513) életéhez." In Források és hagyományképek, edited by Ágnes Stemler, 100-109. Budapest: Országos Széchényi Könyvtár-Gondolat Kiadó, 2014. (Bibliotheca Scientiae \& Artis, 5)

Ekler, Péter. "Augustinus Moravus Olomucensis levele Laki Thuz Jánosnak." Magyar Könyvszemle 128 (2012): 478-480. [Augustinus's letter to Johannes Laki Thuz, 479-480.]

Ekler, Péter. "Classical Literature as a Model and Standard in the 'De Modo Epistolandi' of Augustinus Moravus Olomucensis." In Investigatio Fontium: Griechische und lateinische Quellen mit Erläuterungen. Beiträge der Tagung Klassisches Altertum Byzanz - Humanismus der XI. Ungarischen Konferenz für Altertumswissenschaft, edited by László Horváth, 159-169. Budapest: ELTE Eötvös József Collegium, 2014. (Antiquitas - Byzantium - Renascentia; 10.)

Ekler, Péter. "'Epistolaris itaque formula attenuato stilo ducetur potissimum...' Az ideális stílusnem kérdése Augustinus Moravus Olomucensis ‘De modo epistolandi'jában." In Convivium Pajorin Klára 70. születésnapjára, ediderunt Enikő Békés et Emericus Tegyey, 75-81. Societas Neolatina Hungarica, Sectio Debreceniensis; Institutum Doctrinae Litterarum Academiae Scientiarum Hungaricae. Debrecen Budapest, 2012. (Classica - Mediaevalia - Neolatina VI.). [Augustinus's letter to Heinrich Oswein (in De modo epistolandi); Ad librum (in De modo epistolandi), 80-81.] 
Gaisser, Julia Haig. “Catullus.” In Catalogus Translationum et Commentariorum: Mediaeval and Renaissance Latin translations and commentaries. Annotated lists and guides, vol. 7., editor in chief Virginia Brown, associate editors Paul Oskar Kristeller and F. Edward Cranz, 232-239. Washington, DC: The Catholic University of America Press, 1992. [preface by Augustinus, 233-234.]

Hausmann, Frank-Rutger. "Carmina Priapea." In Catalogus Translationum et Commentariorum: Mediaeval and Renaissance Latin translations and commentaries. Annotated lists and guides, vol. 4., editor in chief F. Edward Cranz, associate editor Paul Oskar Kristeller, 433-439. Washington, DC: The Catholic University of America Press, 1980. [preface of Augustinus, 434-435.]

Hlobil, Ivo, and Eduard Petrů. Humanism and the Early Renaissance in Moravia. Olomouc: Votobia, 1999, 37-40, 157-161, 176-181.

Lencek, Rado. L. "Humanism in the Slavic Cultural Tradition with Special Reference to the Czech Lands." In Renaissance Humanism: Foundations, Forms, and Legacy, edited by Albert Rabil, Jr., vol. 2, 360-361. Philadelphia: University of Pennsylvania Press, 1988.

Martínek, Jan. "De Bohuslai Hassensteinii et Augustini Moravi epistulis." Zprávy Jednoty klasických filologů 4, 1962: 1-13, 96-108.

Mikó, Árpád. "Az olomouci Alberti-corvina - Augustinus Olomucensis könyve." Mữvészettörténeti Értesítő 34, no. 1-2. (1985): 65-72.

Petrů, Eduard. "Augustin Olomoucký a česká epistolografie." In Česká literatura. Časopis pro literární vědu. Praha: Ústav pro českou literaturu AV ČR, 49 (2001): 564-571.

Rothkegel, Martin. Der lateinische Briefwechsel des Olmützer Bischofs Stanislaus Thurzó: eine ostmitteleuropäische Humanistenkorrespondenz der ersten Hälfte des 16. Jahrhunderts. (Hamburger Beiträge zur Neulateinischen Philologie), Münster: LIT Verlag, 2007, 64-65., 101-104. [Augustinus's letter to Stanislaus Thurzó, 101-102.]

Wotke, Karl. "Augustinus Olomucensis (Augustinus Käsenbrot von Wssehrd)." Zeitschrift des deutschen Vereins für die Geschichte Mährens und Schlesiens 2 (1898): 47-71. [Ad libellum (in Dialogus in defensionem poetices), 54-55.; Augustinus's letter to King Vladislaus II, 66-70.]

Wörster, Peter. Humanismus in Olmütz. Landesbeschreibung, Stadtlob und Geschichtsschreibung der ersten Hälfte des 16. Jahrhunderts, 145-155. (Kultur- und geistesgeschichtliche Ostmitteleuropa-Studien; Bd. 5), Marburg: N. G. Elwert Verlag, 1994.

2. Further selected bibliography for Augustinus and his age

Ankwicz-Kleehoven, Hans. Der Wiener Humanist Johannes Cuspinian. Gelehrter und Diplomat zur Zeit Kaiser Maximilians I. Graz-Köln: Hermann Böhlaus Nachf., 1959.

Arnold, Paul. "Die goldene Schale (Patera) des Augustin Kesenbrot und ihre Veränderungen im 18. Jahrhundert." In Jahrbuch der Staatlichen Kunstsammlungen Dresden 26 (1996-1997): 87-98.

Babinger, Franz. Der mährische Humanist Stephan Taurinus und sein Kreis. Würzburg: Werkbund-Druckerei, 1944.

Bajger, Matyáš Franciszek. "Bratr, někdy biskup Jan Filipec (1431-1509) a knihy okolo něj." Problematika historických a vzácných knižních fondů Čech, Moravy a Slezska 19 (2010): 115-144. 
Baletka, Tomáš. “Dvůr olomouckého biskupa Stanislava Thurza (1497-1540), jeho kancelář a správa biskupských statků." Sborník archioních prací 54, no. 1 (2004): 3-236.

Baletka, Tomáš. "Gli inizi dell'episcopato di Stanislav Thurzo, vescovo di Olomouc, e la curia di Roma." Bollettino dell'Istituto Storico Ceco di Roma, edited by Zdeňka Hledíková. Praha: Commissione dell'Istituto Storico Ceco di Roma 7 (2010): 4146.

Baletka, Tomáš. “Osobnost olomouckého biskupa Stanislava Thurza (1497-1540)." Historická Olomouc 17 (2009): 57-64.

Bauch, Gustav. "Analekten zur Biographie des Bischofs Johann IV. Roth." In Studien zur schlesischen Kirchengeschichte. Breslau 1907, 97-101. (Darstellungen und Quellen zur schlesischen Geschichte. Herausgegeben vom Verein für Geschichte Schlesiens. Dritter Band.)

Bauch, Gustav. "Beiträge zur Literaturgeschichte des schlesischen Humanismus. VI." Zeitschrift des Vereins für Geschichte und Alterthum Schlesiens 38 (1904): 318-319.

Bauch, Gustav. Geschichte des Breslauer Schulwesens vor der Reformation. Breslau, 1909. (Codex diplomaticus Silesiae 25.)

Becker, Rainald. "Der Breslauer Bischof Johannes Roth (1426-1506) als 'instaurator veterum' und 'benefactor ecclesiae suae'. Eine Variation zum Thema des Humanistenbischofs." Römische Quartalschrift für christliche Altertumskunde und Kirchengeschichte 96 (2001): 100-123.

Beránek, Karel. “Památka na Jana Filipce v Státním ústředním archivu v Praze." In Ars baculum vitae, edited by Vít Vlnas and Tomáš Sekyrka, 52-55. Praha: Národní galerie, 1996.

Berkovits, Ilona. “Az Esztergomi Ulászló-graduale." Magyar Könyvszemle 65, no. 4 (1941): 342-353.

Boccaccio, Giovanni. Genealogy of the Pagan Gods. Edited and translated by Jon Solomon. Cambridge, MA and London: Harvard University Press, 2011. (The I Tatti Renaissance Library 46.)

Bohuslaus Hassensteinius baro a Lobkowicz. Epistolae. Accedunt epistolae ad Bohuslaum scriptae, edidit Augustinus Potuček (Bibliotheca scriptorum medii recentisque aevorum. Saecula XV-XVI.) Budapest: Egyetemi Nyomda, 1946.

Bohuslaus Hassensteinius a Lobkowicz. Opera poetica, ed. Marta Vaculínová. Monachii et Lipsiae: In aedibus K. G. Saur, 2006.

Boldan, Kamil, and Emma Urbánková. Rekonstrukce knihovny Bohuslava Hasištejnského $z$ Lobkovic. Katalog inkunábulí roudnické lobkovické knihovny. Praha: Národní knihovna České republiky, 2009, 194-195. (num. 62); 264-265. (num. 195).

Bónis, György. A jogtudó értelmiség a Mohács elötti Magyarországon. Budapest: Akadémiai Kiadó, 1971, 311.

Bonorand, Conradin. Aus Vadians Freundes- und Schülerkreis in Wien. St. Gallen: Verlag der Fehr'schen Buchhandlung, 1965. (Vadian-Studien. Untersuchungen und Texte, 8.)

Böhme, Johann Gottlob, and Wilhelm Ernst Tentzel. De Augustino Olomucensi et patera eius aurea ... commentariolus. Accedit eiusdem paterae delineatio a Guil. Ern. Tenzelio. Dresdae; Lipsiae, 1758.

Bunyitay, Vince. A váradi püspökség története. I. A váradi püspökök a püspökség alapitásától 1566. évig. Nagyvárad, 1883, 319-321. 
Cekota, Vojtěch. "Z názorů olomouckých humanistů v první polovině 16. století." Studia Comeniana et historica 13, no. 26 (1983): 163-168.

Celtis, Konrad. Conrad Celtis, Oden, Epoden, Jahrhundertlied. Libri Odarum quattuor, cum Epodo et Saeculari Carmine (1513), übersetzt und herausgegeben von Eckart Schäfer. Tübingen: Gunter Narr Verlag, 2008. (NeoLatina 16.)

Celtis, Konrad. Der Briefwechsel des Konrad Celtis, gesammelt, herausgegeben und erläutert von Hans Rupprich. München: C. H. Beck, 1934. (Veröffentlichungen der Kommission zur Erforschung der Geschichte der Reformation und Gegenreformation, Humanistenbriefe, III. Bd.)

Celtis, Konrad. Fünf Bücher Epigramme von Konrad Celtes, herausgegeben von Karl Hartfelder. Berlin: Calvary, 1881. (Ndr. Hildesheim: Olms, 1963.)

Čermák, Miloslav. "V roce 1513 zemřel Augustin Olomoucký." Střední Morava: vlastivědná revue, Olomouc: Memoria, 19, no. 36 (2013): 116-118.

Chlíbec, Jan. "Medallions with the Portraits of Ladislav z Boskovic and his Wife Magdaléna z Dubé a Lipého." In Matthias Corvinus, the King. Tradition and renewal in the Hungarian royal court 1458-1490, edited by Péter Farbaky and András Végh, 277-278. Budapest: Budapest History Museum, 2008.

Cracolici, Stefano. "The Art of Invective." In Petrarch: A Critical Guide to the Complete Works, edited by Victoria Kirkham and Armando Maggi, 255-262, 440-449. Chicago: The University of Chicago Press, 2009.

Curtius, Ernst Robert. Evropská literatura a latinský středověk. Praha: Triáda, 1998, 152153.

Cuspinianus, Iohannes. Johann Cuspinians Briefwechsel, gesammelt, herausgegeben und erläutert von Hans Ankwicz v. Kleehoven. München: C. H. Beck'sche Verlagsbuchhandlung, 1933. (Veröffentlichungen der Kommission zur Erforschung der Geschichte der Reformation und Gegenreformation, Humanistenbriefe, II. Bd.)

Csáky, Moritz. “Die 'Sodalitas litteraria Danubiana'. Historische Realität oder poetische Fiktion des Conrad Celtis?" In Die österreichische Literatur. Ihr Profil von den Anfängen im Mittelalter bis ins 18. Jahrhundert, Teil 2, herausgegeben von Herbert Zeman, 739-758. Graz: ADEVA, 1986.

Csapodi, Csaba. The Corvinian Library. History and Stock. Budapest: Akadémiai Kiadó, 1973. Nr. 115.

Csapodi, Csaba. “Die erhalten gebliebenen Bücher des Johann Filipec (Pruis), Bischof von Grosswardein." Gutenberg-Jahrbuch (1975): 338-340.

Csapodi-Gárdonyi, Klára. Die Bibliothek des Johannes Vitéz. Budapest: Akadémiai Kiadó, 1984.

De Nava, Ludovica. "L'epistola di Girolamo Avanzi ad Agostino Moravo di Olomuc." Lettere italiane 45 (1993): 402-426.

Fedeles, Tamás. “Egy Jagelló-kori humanista pályaképe: Csulai Móré Fülöp (1476/14771526)." Levéltári Közlemények 78/2. (2007): 35-84.

Feuchter, Jörg et al. "Cultural Transfers in Dispute: An Introduction." In Cultural Transfers in Dispute: Representations in Asia, Europe and the Arab World since the Middle Ages, edited by Jörg Feuchter, Friedhelm Hoffmann and Bee Yun, 15-37. Frankfurt am Main and New York: Campus Verlag, 2011.

Flood, John. Poets Laureate in the Holy Roman Empire: A Bio-bibliographical Handbook, L-R. Vol. 3., 1104-1105. Berlin - New York: De Gruyter, 2006. 
Foltýnová-Mikulcová, Pavlína. “Jan Filipec, diplomat ze sklonku středověku." Dějiny a současnost 21, no. 1 (1999): 11-15.

Gajdoš, Vševlad Josef OFM. "Z dejín františkánskej knižnice v Skalici." In Skalica v minulosti a dnes, edited by Ján Buchta, Ján Sloboda, and Zora Viestová, 224-232. Bratislava: Obzor, 1968.

Gastgeber, Christian. "Die Erschließung neuer Quellen. Der Zugang zum Griechischen im Wiener Humanismus." In Ars - Artes - Artisten - Wissenschaft. Die Universität Wien im Humanismus, herausgegeben von Thomas Maisel und Christian Gastgeber, im Druck. Wien: Präsens Verlag, 2014. (Singularia Vindobonensia 4.)

Gastgeber, Christian und Elisabeth Klecker (Hrsg.). Iohannes Cuspinianus (1473-1529). Ein Wiener Humanist und sein Werk im Kontext. Wien: Präsens Verlag, 2013. (Singularia Vindobonensia 2.)

Gastgeber, Christian. Miscellanea Codicum Graecorum Vindobonensium II. Die griechischen Handschriften der Bibliotheca Corviniana in der Österreichischen Nationalbibliothek. Provenienz und Rezeption im Wiener Griechischhumanismus des frühen 16. Jahrhunderts. Wien: Verlag der Österreichischen Akademie der Wissenschaften, 2014. (Veröffentlichungen zur Byzanzforschung 34.)

Genthon, István. “Egy budai humanista aranycsészéje." Tanulmányok Budapest múltjából III (1934): 130-143.

Glomski, Jacqueline. Patronage and Humanist Literature in the Age of the Jagiellons. Toronto: University of Toronto Press, 2007.

Graciotti, Sante. "Tradizione testuale e tradizione letteraria nell' Antilogion Guarini et Poggii di Augustinus Moravus." In Italia e Boemia nella cornice del Rinascimento europeo, edited by Sante Graciotti, 131-152. Firenze: Leo S. Olschki Editore, 1999.

Graf-Stuhlhofer, Franz. Humanismus zwischen Hof und Universität. Georg Tannstetter (Collimitius) und sein wissenschaftliches Umfeld im Wien des frühen 16. Jahrhunderts. Wien: WUV-Universitätsverlag, 1996.

Hajdukiewicz, Leszek. “Die Krakauer Universität zur Zeit der frühen Renaissance." In The Jagiellonian University in the Evolution of European Culture, edited by Jerzy Wyrozumski, 25-48. Kraków: Secesja, 1992.

Harder, Hans Bernd. "Zentren des Humanismus in Böhmen und Mähren." In Studien zum Humanismus in den böhmischen Ländern, Bd. 11, edited by Hans-Bernd Harder and Hans Rothe, 21-37. Köln and Wien: Böhlau, 1988.

Hlaváček, Petr. Čeští františkáni na přelomu středověku a novověku. Praha: Academia, 2005.

Hlobil, Ivo, and Eduard Petrů. Humanism and the Early Renaissance in Moravia. Olomouc: Votobia, 1999.

Hlobil, Ivo, and Eduard Petrů. Humanismus a raná renesance na Moravě. Praha: Academia, 1992.

Hlobil, Ivo. “Jan Filipec a studia Jana z Kunovic." Vlastivědný věstník moravský 42, no. 3 (1990): 403-404.

Hlobil, Ivo. “K stavebněhistorické analýze tovačovského zámku." In Morava na prahu nové doby, edited by František Hýbl, 110-112. Přerov: Muzeum Komenského, 1995.

Hlobil, Ivo. “Morava a uherská (italská) renesance za Matyáše Korvína.” Časopis Matice moravské 110, no. 2 (1991): 325-338. 
Hlobil, Ivo. "Úvodní glosy k nástěnné malbě pozdní gotiky a rané renesance na Olomoucku." In Od gotiky k renesanci III., Olomoucko, edited by Ivo Hlobil and Marek Perůtka, 406-429. Olomouc: Muzeum umění, 1999.

Hoffmann, Edith. Régi magyar bibliofilek. Budapest: Magyar Bibliophil Társaság, 1929, 122-124.

Horváth, Richárd and Tibor Neumann. Ecsedi Bátori István. Egy katonabáró életpályája, 1458-1493. Budapest: MTA BTK Történettudományi Intézet, 2012, 127. (Magyar történelmi emlékek. Értekezések)

Hutten, Ulrich. Ulrichi Hutteni equitis Germani opera, quae reperiri potuerunt omnia, ed. Eduardus Böcking, vol. 1, Epistolae Ulrichi Hutteni equitis item ad eundem deque eodem ab aliis ad alios scriptae. Leipzig: Teubner, 1859 (Ndr. 1963).

Jakubec, Ondřej. “Olomoučtí biskupové jako renesanční mecenáši?.” In Pro arte. Sborník k poctě Ivo Hlobila, edited by Dalibor Prix, 261-270. Praha: Artefactum, 2002.

Janál, Rudolf. "Stanislav Thurzo z Bethlenfalvy a Morava ve stycích se světem uherským a polským v posledních letech 15. a 1. pol. 16. stol." PhD diss., Palacký University in Olomouc, 1949.

Kalhous, David. "Osudy jednoho časopisu. Zeitschrift des deutschen Vereins für die Geschichte Mährens und Schlesiens." In Německá mediavistika v českých zemích do roku 1945, edited by František Šmahel and Pavel Soukup, 95-105. Praha: Filosofia, 2004.

Kalous, Antonín. "Boskovice urai Mátyás király diplomáciai és politikai szolgálatában." Századok 141 (2007): 375-389.

Kalous, Antonín. "Církev a biskupství." In Dějiny Olomouce 1, edited by Jiř́ Šmeral, 216-238. Olomouc: Univerzita Palackého, 2009.

Kalous, Antonín. "Itineráŕ Jana Filipce (1431-1509)." Sborník prací historických (Acta Universitatis Palackianae Olomucensis, Historica) 34 (2008): 17-44.

Kalous, Antonín. "Jan Filipec v diplomatických službách Matyáš Korvína." Časopis Matice moravské 125, no. 1 (2006): 3-32.

Kalous, Antonín. "Spor o biskupství olomoucké." Český časopis historický 105, no. 1 (2007): 1-39.

Kasza, Péter. Egy korszakváltás szemtanúja. Brodarics István pályaképe. Pécs-Budapest, 2015, 29-34.

Kipf, Johannes Klaus. "Johannes Langer von Bolkenhain." In Deutscher Humanismus, Verfasserlexikon 1480-1520. Bd. II. L-Z, Lieferung 1., ed. Franz Josef Worstbrock, 27-31. Berlin-New York: Walter de Gruyter, 2009.

Kipf, Johannes Klaus. "Sigismund Buchwald." In Deutscher Humanismus, Verfasserlexikon 1480-1520, Bd. I. A-K, hrsg. v. Franz Josef Worstbrock, 296-299. Berlin-New York: Walther de Gruyter, 2008.

Kiss, Farkas Gábor. "Franciscus Pescennius Niger Báthory Miklós váci püspök udvarában és a Scholasticum Orosianae iuventutis dramma," Magyar Könyvszemle 129 (2013): 265-281.

Kiss, Farkas Gábor. “Vitéz és Janus után: a latin nyelvű irodalom Mátyás uralkodásának második felében és a Jagelló-korban." In Magyar irodalom, főszerk. Gintli Tibor. Budapest: Akadémiai Kiadó, 2010, 74-75. (Akadémiai kézikönyvek)

Klaniczay, Tibor. Alle origini del movimento accademico ungherese. A cura di Amedeo Di Francesco, Judit Papp, Orsolya Száraz. Presentazione di István Monok. Premessa di Amedeo Di Francesco. Alessandria: Edizioni dell'Orso, 2010, 89-90. 
Klaniczay, Tibor. "Celtis und die Sodalitas Litteraria per Germaniam." In Respublica Guelpherbytana, ed. August Buck, Martin Bircher and Paul Raabe, 79-105. Amsterdam: Edition Rodopi, 1987. (Wolfenbütteler Beiträge zur Renaissanceund Barockforschung. Bd. 6.)

Klaniczay, Tibor. A magyarországi akadémiai mozgalom elötörténete. Budapest: Balassi, 1993, 50-77.

Klecker, Elisabeth. "Hieronymus Balbus." In Deutscher Humanismus 1480-1520. Verfasserlexikon, Band 1, A-K, hrsg. v. Franz Josef Worstbrock, 109-115. BerlinNew York: De Gruyter, 2008.

Kolár, Jaroslav. "Dva světy humanistického dialogu." Slavia - časopis pro slovanskou filologii 65, no. 3 (1996): 347-351.

Konečný, Lubomír. "Augustine Käsenbrot of Olomouc, His Golden Bowl in Dresden, and the Renaissance Revival of "Poetic" Bacchus." Artibus et Historiae 24, no. 48 (2003): 185-197.

Kouřil, Miloš. "Augustin Olomoucký, 1467-1513." In Historiografie Moravy a Slezska, edited by I. Barteček, 13-20. Olomouc: Univerzita Palackého v Olomouci, 1, 2001.

Králík, Oldřich. "Dvě zprávy o olomouckých humanistech." Časopis Matice moravské 68, no. 3-4 (1948): 283-327.

Králík, Oldřich. "Moravský humanista Wolfgang Heiligmaier." Listy filologické 72, no. 2 (1948): 191-202.

Křenková, Zuzana. "K nejstarším dějinám a stavebnímu vývoji kláštera františkánů observantů v Olomouci." Vlastivědný věstník moravský 62, no. 2 (2010): 152-169.

Kronthal, Berthold and Heinrich Wendt. Politische Correspondenz Breslaus im Zeitalter des Königs Matthias Corvinus. Breslau, 1894. (Scriptores rerum Silesiacarum 14.)

Leiner, Wolfgang. "Dedikation." In Historisches Wörterbuch der Rhetorik. Vol. 2., ed. Gert Ueding, 452-457. Tübingen: Max Niemeyer Verlag, 1994.

Machilek, Franz. "Georgius Sibutus Daripinus und seine Bedeutung für den Humanismus in Mähren." In Studien zum Humanismus in den böhmischen Ländern, edited by Hans-Bernd Harder and Hans Rothe, 207-241. Köln-Wien: Böhlau, 1988.

Machilek, Franz. "Konrad Celtis und die Gelehrtensodalitäten insbesondere in Ostmitteleuropa." In Humanismus und Renaissance in Ostmitteleuropa vor der Reformation, edited by Winfried Eberhard and Alfred A. Strnad, 137-155. Köln, Weimar and Wien: Böhlau, 1996.

Machilek, Franz. "Der Olmützer Humanistenkreis." In Der polnische Humanismus und die europäischen Sodalitäten, edited by Stephan Füssel and Jan Pirozyński, 111-135. Wiesbaden: Harrassowitz, 1997.

Macůrek, Josef. “Turzonowie na Morawach i na Śląsku na końcu XV I w pierwzsej połowie XVI wieku. Z historii stosunków czesko-polskich w okresie humanizmu." Śląnski kwartalnik historyczny Sobótka 14 (1959): 25-47.

Marosi, Ernő (Hrsg). Auf der Bühne Europas. Der tausendjährige Beitrag Ungarns zur Idee der Europäischen Gemeinschaft. Budapest: Forschungsinstitut für Kunstgeschichte der Ungarischen Akademie der Wissenschaften-Balassi Kiadó, 2009, 86-87.

Martínek, Jan. "Ke kritice a datovaní básníckého díla Bohuslava z Lobkovic." Listy filologické - Folia philologica 103 (1980): 235.

Martínek, Jan-Dana Martínková. “Žádost moravské šlechty papeži Alexandru VI. o potvrzení Bohuslava z Lobkovic olomouckým biskupem." Listy filologické - Folia philologica 102, no. 2/3 (1979): 145-147. 
Martínková, Dana. “Ohlas vynálezu knihtisku v naší latinsky psané literatuře." In Kniha a knihtisk v českých zemích od husitství do Bílé hory, edited by Josef Polišenský and František Šmahel, 151-167. Praha: Academia, 1970.

Měštánek, Tomáš. Biskup Jan Filipec (1431-1509) a středoevropská politika. Zlín: Krajská Knihovna Františka Bartoše, 2003.

Miggiano, Gabriella. "Galeotto Marzio da Narni. Profilo biobibliografico (II)," Il Bibliotecario 33-34 (1992): 93.

Mikó, Árpád. "Il De re aedificatoria e la corte di re Mattia Corvino." Nuova Corvina 16 (2004): 71-76.

Mikó, Árpád. “Leon Battista Alberti De re aedificatoriája és Mátyás király udvara.” In "És az oszlopok tetején liliomok formáltattak vala." Tanulmányok Bibó István 70. születésnapjára, szerk. Tóth Áron, 67-72. Budapest: CentrArt Egyesület, 2011.

Mikó, Árpád. A reneszánsz Magyarországon. Budapest: Corvina, 2009, 63-64. (Stílusok - korszakok)

Minařík, Klemens OFM. “Příspěvek k životopisu Jana Filipce." Sborník Historického kroužku 28 (1927): 61-67, 127-134.

Monok, István. "A Bibliotheca Corviniana és a nyomtatott könyvek." Magyar Könyoszemle, 124. (2008): 264.

Müller, Gernot Michael. Die »Germania generalis« des Conrad Celtis. Studien mit Edition, Übersetzung und Kommentar. Tübingen: Max Niemeyer Verlag, 2001. (Frühe Neuzeit, Bd. 67.)

Nešpor, Václav. "O původu moravského humanisty dr. Augustina Olomouckého." Český časopis historický 38 (1932): 541-546.

Petrů, Eduard (ed. and trans.). Humanisté o Olomouci. Praha: Památník národního písemnictví, 1977.

Petrů, Eduard. “Olomoucký humanismus a jeho polské podněty." In Slavistický sborník olomoucko-lublinský, 27-38. Praha: SPN, 1974.

Petrů, Eduard. "Societas Maierhofiana." Historická Olomouc a její současné problémy 3 (1980): 183-189.

Prasek, Vincenc. "'Augustin doktor' a Olomoučané.” Časopis Matice moravské 26 (1902): 30-42.

Pumprla, Václav. "Poznámky k zámecké knihovně Ctibora Tovačovského z Cimburka." In Morava na prahu nové doby. Sborník príspěvků z konference konané 22. - 23. června 1994 u př́ležitosti úmrtí Ctibora Tovačovského z Cimburka, edited by František Hýbl, 69-70. Přerov: Muzeum Komenského, 1995.

Ritoók-Szalay, Ágnes. "Der Humanismus in Ungarn zur Zeit von Matthias Corvinus." In Humanismus und Renaissance in Ostmitteleuropa vor der Reformation, edited by Winfried Eberhard, 151-171. Köln: Böhlau, 1996.

Robert, Jörg. "Celtis, Konrad." In Deutscher Humanismus 1480-1520. Verfasserlexikon, Band 1, A-K, hrsg. v. Franz Josef Worstbrock, 375-427. Berlin, New York: De Gruyter, 2008.

Robert, Jörg. Konrad Celtis und das Projekt der deutschen Dichtung. Tübingen: Niemeyer, 2003.

Rothkegel, Martin. “Nepřátelé-přátelé umění. Obrazoborectvía renesanční sběratelství v mikulovské křtěnecké reformaci (1526-1536)." In Sborník Regionálního muzea v Mikulově, edited by Stanislava Vrbková, 118-134. Mikulov: Regionální muzeum v Mikulově, 2008. 
Rothkegel, Martin. “Ungarn und die Türkenkriege im Spiegel der Briefe des Olmützer Bischofs Stanislaus Thurzó aus den Jahren 1501-1540." Comenius-Jahrbuch 20 (2012): 109.

Ryba, Bohumil. "Filip Beroaldus a čeští humanisté." In Zpráva o činnosti městského musea v Č. Budějovicích za léta 1932 a 1933, 1-39. České Budějovice: Karel Fiala, Městské museum, 1934.

Saktorová, Helena. Turzovské knižnice. (Osobné knižné zbierky a knihy dedikované členom rodu Turzovcov). Martin: Slovenská národná knižnica, 2009, 171.

Schirrmeister, Albert. "Vadian, Joachim." In Deutscher Humanismus 1480-1520. Verfasserlexikon, Bd. 2, hrsg. von Franz Josef Worstbrock. Berlin, New York: De Gruyter, 2013. Sp. 1177-1237.

Šimák, Josef Vítězslav. "»Series« Augustina Olomouckého. (Př́spěvek k dějinám českého dějepisectví)." In Český časopis historický, edited by Josef Pekař, Historický klub 37, no. 3-4, (1931): 584-593.

Šmahel, František. "Die Anfänge des Humanismus in Böhmen." In Humanismus und Renaissance in Ostmitteleuropa vor der Reformation, edited by Winfried Eberhard, 189-214. Köln: Böhlau, 1996.

Sottili, Agostino. “Der Bericht des Johannes Roth über die Kaiserkrönung von Friedrich III." In Deutsche Handwerker, Künstler und Gelehrte im Rom der Renaissance, edited by Stephan Füssel and Klaus A. Vogel, 46-100. Wiesbaden: Harrasowitz Verlag, 2000. (Pirckheimer Jahrbuch, Bd. 15/16)

Sottili, Agostino. "The Humanist Education of Johannes Roth, the Prince-Bishop of Breslau." In id., Humanismus und Universitätsbesuch: Die Wirkung italienischer Universitäten auf die Studia Humanitatis nördlich der Alpen, 396-412. Leiden: Brill, 2006.

Storchová, Lucie. "Latinský humanismus." In Dějiny Olomouce, Vol. 1, edited by Jindřich Schulz, 303-308. Olomouc: Univerzita Palackého, 2009.

Storchová, Lucie. Paupertate styloque connecti. Utváření humanistické učenecké komunity v českých zemích. Praha: Scriptorium, 2011.

Storchová, Lucie. “The Role of Trans/National Meta/Narratives in Representations of Cultural Transfer: The Case of European and Bohemian Renaissance Humanism/s." In Processes of Cultural Exchange in Central Europe, 1200-1800, edited by Veronika Čapská et al., 35-75. Opava: European Social Fund - Silesian University in Opava, 2014.

Struever, Nancy. "Petrarch's 'Invective contra medicum': An Early Confrontation of Rhetoric and Medicine." Modern Language Notes 108 (1993): 659-679.

Svoboda, Karel. "Augustina Olomouckého 'Dialog na obranu básnictví." Listy filologické / Folia philologica 69 (1942): 20-33.

Svoboda, Karel."Il dialogo 'In difesa della poesia' di Agostino da Olomouc." Lettere italiane 8 (1956): 34-49.

Szörényi, László. “L'influenza della Farsaglia di Lucano sull'epopea tardo-umanista latina in Ungheria; Stephanus Taurinus: Stauromachia." Neohelicon 27, no. 2 (2000): 97-111.

Tangl, Karlmann. “Johann I. Rott (1468-1482)." In Reihe der Bischöfe von Lavant, edited by Karlmann Tangl, 175-197. Klagenfurt: Johann Leon Verlag, 1841.

Tringli, István. "Az 1481. évi szlavóniai közgyűlés." In Tanulmányok Borsa Iván tiszteletére, edited by Enikő Csukovits, 301-302, 307-308, 310-311. Budapest: Magyar Országos Levéltár, 1998. 
Truhláŕ, Josef. Humanismus a humanisté v Čechách za krále Vladislava II. V Praze: Č. Akademie Fr. Josefa, 1894. (Rozpravy Č. Akademie Fr. Josefa, III. 3. 4.)

Véber, János. "Az idősebb Filippo Beroaldo és Váradi Péter barátsága könyvajánlások tükrében." Magyar Könyvszemle 122 (2006): 397-419.

Vorel, Jaroslav (ed.). Humanistická konference 1966, edited by Jaroslav Vorel. Praha: Kabinet pro studia řecká, římská a latinská, ČSAV, 1966.

Wakounig, Marija and Simoniti, Primož. Humanismus bei den Slovenen: slovenische Humanisten bis zur Mitte des 16. Jahrhunderts, 289-293. Wien: Verlag der Österreichischen Akademie der Wissenschaften, 2008. (Zentraleuropa-Studien, 11.)

Worstbrock, Franz Josef. “Johannes Roth." In Deutscher Humanismus 1480-1520. Verfasserlexikon, Bd. 8., 269-275. Berlin - New York: Walther de Gruyter, 1992.

Worstbrock, Franz Josef. "Taurinus, Stephanus (Stierochs, Stieröxel)." In Deutscher Humanismus 1480-1520. Verfasserlexikon, Bd. 2, L-Z, hrsg. von Franz Josef Worstbrock, 1052-1058. Berlin, New York: De Gruyter, 2013.

Wotke, Karl. "Augustinus Olomucensis (Augustinus Käsenbrot von Wssehrd)." Zeitschrift des deutschen Vereins für die Geschichte Mährens und Schlesiens 2 (1898): 47-71.

Wotke, Karl. “Der Olmützer Bischof Stanislaus Thurzó von Béthlenfalva (1497-1540) und dessen Humanistenkreis." Zeitschrift des deutschen Vereins für die Geschichte Mährens und Schlesiens 3, no. 4 (1899): 337-388.

Wörster, Peter. "Breslau und Olmütz als humanistische Zentren vor der Reformation." In Humanismus und Renaissance in Ostmitteleuropa vor der Reformation, edited by Winfried Eberhard and Alfred A. Strnad, 215-227. Köln, Weimar and Wien: Böhlau, 1996.

Wörster, Peter. "Der olmützer Humanistenkreis unter Stanislaus Thurzó." In Studien zum Humanismus in den böhmischen Ländern, edited by Hans-Bernd Harder and Hans Rothe, 21-37, Köln-Wien: Böhlau, 1988.

Wörster, Peter. "Von Handschriften-und Büchersammlungen zu neuen humanistischen Werken: einige Beobachtungen zwischen Olmütz und Großwardein." In Buchund Wissenstransfer in Ostmittel- und Südosteuropa in der Frühen Neuzeit, edited by Detlef Haberland and Tünde Katona, 177-181. München: R. Oldenbourg, 2007.

Wörster, Peter. "Zwei Beiträge zur Geschichtsschreibung in Olmütz in der ersten Hälfte des 16. Jahrhunderts." In Studien zum Humanismus in den böhmischen Ländern, Bd. 17, Teil III. Die Bedeutung der humanistischen Topographien und Reisebeschreibungen der humanistischen Zeit bis Zeit Balbins, edited by Hans-Bernd Harder and Hans Rothe, 35-49. Köln, Weimar and Wien: Böhlau, 1993.

Zaccaria, Vittorio. “La difesa della poesia nelle 'Genealogie' del Boccaccio." Lettere italiane 38 (1986): 281-311. 


\section{INDEX}

A

Ábel, Jenő 12-16, 18, 157, 162-163, 185

Adamik, Tamás 10

Aegidius 29

Aegidius Moravus (father of Augustinus) 104, 158

Aesculapius 84

Aesticampianus, Johannes Rhagius see Rack, Johannes

Agricola, Rudolfus (Rudolf Agricola Junior/ Wasserburgensis) 36, 167

Agrippa, Cornelius Henricus 36

Albano, Iustus de 19

Alberti, Leon Battista 48, 186, 192

Albucius 82

Albumasar 85

Alcibiades 94

Alcinous 28

Alfonso X of Castile, the Wise 80, 82-84, 110, 184

Altheimer, Konrad 155

Amaseo, Girolamo 38

Angyal, Endre 7

Ankwicz von Kleehoven, Hans 24-25, 29, 186, 188

Anthony Musa 82

Anzelewsky, Fedja 87-88

Aperbach (Eberbach/Aperbacchus), Petreius 27

Apitius, Christophorus 155

Apollo 12, 84, 89, 110, 142, 144-146, 163, 172$173,180,181$

Apollodorus 85

Apuleius, Lucius 12, 39, 41, 53, 87, 170

Aragona, Federico d' 16

Arbenz, Emil 29

Aristotle 12, 118

Augustine of Hippo 71-76, 78

Augustinus Moravus Olomucensis 1, 3-6, 8-29, 42, 47-48, 51, 55, 61, 63, 65-72, 74-75, 77-91, 93-99, 101-102, 104-110,
113-115, 138-141, 149, 151-163, 165-168,

170, 183-187, 189, 194-195, 205, 208, 215

Augustus (emperor) 144

Aulus Gellius see Gellius, Aulus

Avantius, Hieronymus 15, 75, 81, 184, 188

Avanzi, Girolamo see Avantius, Hieronymus

Avicenna 48, 58

\section{B}

Babinger, Franz 140, 186

Bacchus 15, 17, 144, 176, 191

Badensis, Jacobus (Jakob II von Baden) 38

Badius Ascensius, Jodocus 39

Bajger, Matyáš Franciszek 5, 45, 49-50, 56, 186, 215-216

Baker, Patrick 83

Bakócz, Tamás 41

Balbi, Girolamo see Balbus, Hieronymus

Balbus, Hieronymus (Balbi, Girolamo) 11, 13-14, 21, 52, 69, 74-75, 113, 191

Baletka, Tomáš 59, 139, 187

Balogh, István 90

Barteček, Ivo 153, 191

Bartók, István 10

Bartoniek, Emma 115-116, 126, 129, 132

Basil the Great 116

Basilius Magnus see Basil the Great

Basilius, Johannes 110

Bassareus 5, 77, 84-85, 93-99

Báthory, István 158

Báthory, Miklós 86, 107, 190

Bauch, Gustav 64-66, 90, 101-102, 105, 152, 157-158, 161, 163, 185, 187

Bausi, Francesco 77

Bavarus, Jan (Johannes V Bavor) 165-166

Beatrix, queen of Hungary 120, 123-124, 129, 134, 137

Beatus Rhenanus 139

Bebel, Heinrich 87

Beck, Erasmus see Pinifer, Erasmus

Becker, Rainald 78, 187 
Békés, Enikő 4, 10, 69, 102, 157, 185

Bellinati, Claudio 84

Bellomo, Manlio 35

Bellona 91, 164

Beránek, Karel 49, 187

Berkovits, Ilona 56, 187

Bernard of Clairvaux (Ps) 48

Bernhaupt (Schwenter), Pangratz 87

Beroaldo, Filippo the Elder 5, 31, 35-42, 48, 53, 79, 101, 108-111, 193-194, 207

Beroaldo, Vincenzo 38, 109

Besicken, Johannes de 16

Bessarion 6, 28-29, 113-122, 124, 126, 133, 137-138, 215

Bianchini, Giovanni see Blanchinus, Johannes

Bircher, Martin 66, 191

Birkenmajer, Aleksander 168

Bisticci, Vespasiano 135

Blanchinus, Johannes (Bianchini, Giovanni) $37,81,82,105,107,184$

Boccaccio, Giovanni 31, 77, 86-88, 91, 187, 194

Boëthius 87

Boger, Heinrich 31

Boháček, Miroslav 33

Boka, László 9

Boldan, Kamil 10, 50, 187

Bolkenhain, Johannes see Langer von Bolkenhain, Johannes

Bollbuck, Harald 10

Bolonyai, Gábor 109

Bonfini, Antonio 51, 53-54, 57-58, 94, 113

Bonomo, Francesco 11

Bonomo, Pietro 11

Bononius, Hieronymus 82

Boorius Caetianus, Georgius 21-22

Borkowska, Urszula 51

Bornemisza, Pál 38

Borsa, Gedeon 12, 38, 118

Borsa, Iván 193

Boskovic, Ladislav z (Ladislaus of Boskovice) 79-80, 188

Boskovic, Prothasius z (Prothasius of Boskovice) 45, 47, 51, 55, 58, 140

Bottari, Guglielmo 83

Böcking, Eduardus 28, 190

Bracciolini, Poggio 26-27, 62, 87, 184, 189

Brizzi, Gian Paolo 36

Brodaricius (Brodarics, Brodarius), Stephen 41, 190

Brown, Virginia 75, 81, 186

Brunori, Lia 115

Brutus 104
Brutus, Joannes Michael (Bruto, Gian Michele) 47

Bubryák, Orsolya 114

Buchta, Jan 57, 189

Buchwald, Sigismund 64-65, 190

Buck, August 42, 66, 191

Bunyitai, Vincze 47, 52, 54, 57

Busche, Hermann von dem 31

Bydžova a Kunovic, Duchek z 55

Bylica, Martyn 127

\section{C}

Caesar, Caius Iulius 26-27, 41, 104, 111, 169, 177,184

Calcagnini, Celio 113

Calcaterra, Carlo 31

Calderinus, Domitius 19

Calentius, Elisius (Calenzio, Elisio) 15

Calfurnio, Giovanni see Calphurnio, Giovanni

Callimachus 143

Calliope 145

Calphurnio, Giovanni 111

Canter, Andreas 31

Canter, Jakob 31

Capistran, St John 48, 53, 55

Capitani, Ovidio 37

Čapská, Veronika 150, 193

Caragounis, Chrys C. 19

Carbo, Girolamo 76

Carducci, Giosuè 35

Castello, Francesco da 120-121, 123-124, 128$129,133,135$

Catull 15, 75, 81-82, 143, 184, 186

Celsus 85

Celtis, Konrad 11-24, 36, 52, 64, 66-67, 86-87, 93, 96-99, 102, 140-141, 154-155, 157, $163,184,188,191-192$

Ceres 89, 158

Cermann, Regina 120-122, 126-127, 130-131

Cervinus, Aelius Lampridius 89

Charles IV (emperor) 56

Charles V (emperor) 39, 114

Chesserius, Michael see Kesserü, Mihály

Chlíbec, Jan 80, 188

Christ 16, 28, 47, 53, 58, 73, 89-90, 141, 146, $158,162,164-165,179,183$

Chrysostomus, St John 116

Cicero 97, 104, 167, 178

Cilli, Ulrich von 62-63

Ciołek, Erazm 39

Claudian 76

Clement VI (pope) 85 
Clio 98

Collauer (Collawer), Johannes 39

Collimitius, Georg Tannstetter 21, 28, 189

Colliva, Paolo 32-35, 42

Columna, Guido de 121, 132-133

Copernicus, Nicolaus 36

Cornelius ze V̌̌ehrd, Viktor 51

Corvinus see Matthias Corvinus

Costa, Emilio 42

Cracolici, Stefano 77, 188

Crassus 104, 175, 179

Crecelius, Wilhelm 83

Crijević, Ilija see Cervinus, Aelius Lampridius

Ctiborius / Stiborius, Andreas 61, 78, 104, 153, 158

Ctiborův, Ondřej see Ctiborius, Andreas

Curtius, Ernst Robert 71, 82, 188

Cuspidius (Spieß), Henricus 11

Cuspinianus, Johannes 11, 24-27, 29, 186, 188-189

Czapla, Ralf Georg 11, 14-15, 65, 78, 101, 183, 185

Cziráki, Zsuzsanna 61

Cs

Csáky, Moritz 11, 66, 188

Csapodi, Csaba 48, 115, 122, 126, 128-130, 132, 188

Csapodi-Gárdonyi, Klára 47, 49-50, 119, 121, $126,132,188$

Csehy, Zoltán 5, 69, 216

Csulai Móré, Fülöp (Philippus Cyulanus) 41, 188

\section{D}

d'Este, Borso 138

d'Este, Ippolito 113

Damascenus, Johannes 116

De Nava, Ludovica 81, 188

Denis, Michael 90

Diana 144

Diomedes 86-87

Dionysius of Halicarnassus 167, 178

Dionysus Grammaticus 97-99

Dixon-Kennedy, Mike 99

Dobossy, László 7

Dronke, Peter 87

Dubé a Lipého, Magdaléna z 80, 188

Dubravius, Johannes (Jan) 46, 139-141

Duchek z Bydžova a Kunovic see Bydžova a Kunovic, Duchek z

Duellius, Raymundus 62
E

Eberhard, Winfried 45, 52, 59, 154, 191-194

Eck, Valentin 6, 90, 144, 167-170, 174, 180-181

Ekler, Péter 3-5, 10, 41, 61, 66, 69, 101-103, 118-119, 157, 161, 185, 216

Elbel, Petr 10

El-Kholi, Susann 90

Ellinger, Georg 31

Elsner, Jakob 121, 131

Endlicher, Stefan 79

Ennius Klatovský, Šimon 144-145

Epicure 47

Erasmus of Rotterdam 19, 89, 139-142, 152

Erdődy (Bakócz), János 41

Erdődy (Bakócz), Pál 41

Eyb, Albrecht von 62

F

Fabian, Claudia 136

Fabri, Johannes 146

Fabrizio-Costa, Silvia 108

Farbaky, Péter 80, 115, 124, 188

Farkas, Gábor Farkas 10

Fasoli, Gina 32

Fauerhane, Henning 31

Fedele, Cassandra 101, 106-107

Fedeles, Tamás 10, 101-102, 188

Ferdinand I (emperor) 39, 140, 142, 145-146

Feuchter, Jörg 149-150, 188

Fiano, Francesco da 88-89

Ficino, Marsilio 84, 98

Filipec, Jan (Filipecz, Pruis) 5, 45-59, 140, 154, 186, 188-190, 192, 207

Finger, Richard 32-33, 36

Fischer, Andreas see Pisciculus, Andreas

Flood, John 64, 188

Florus, Lucius Annaeus 167, 178

Fógel, József 69

Foltýnová-Mikulcová, Pavlína 48, 189

Fonte (Fontius), Bartolommeo della 90

Forderer (Kühorn), Johannes 39

Földesi, Ferenc 117-119, 126, 133

Francesco, Amedeo Di 9, 190

Francia, Stephanus de 42

Franck, Sebastian 31

Frati, Lodovico 38, 40

Frederick III (emperor) 62, 64, 193

Freher, Marquard 46

Friedländer, Ernst 38, 40

Friedrich III see Frederick III

Frölinkint, Jakob 31

Fuchs, Martina 114 
Fulgentius the Mythographer 87-89, 91, 167, 169,178

Füssel, Stephan 62, 154, 191, 193

\section{G}

Gaiado, Enrico 39

Gaisser, Julia Haig 75, 81, 186

Gajdoš, Vševlad Josef 57, 189

Galavics, Géza 114

Galenus 85

Galeotto Marzio 51, 69, 94, 157, 162, 192

Gamillscheg, Ernst 47, 122

Gánóczy, Antonius 57

Garin, Eugenio 37-38, 40-41

Garzoni, Giovanni 37

Gąsiorowski, Antoni 53

Gastgeber, Christian 5, 9, 11, 14, 18-19, 24, 90 , $117,157,163,189,215-216$

Gatti, Giovanni 117-118

Gellius, Aulus 37-39

Gerlic, Henryk 102

Germanus, Nicolaus 19

Gillert, Karl 89

Giustiniani, Sebastiano 90, 163, 184

Glomski, Jacqueline 144, 168-169, 189

Glotzer, Siegmund 167, 169

Gorgias 84

Gossinger, Sigmund 39

Göschl (Iglaviensis), Martin 141

Graf-Stuhlhofer, Franz 28, 189

Graman, Richard 38

Gregory of Nazianze see Nazianzenus, Gregorius

Gregory the Great 72

Greiderer, Vigilius 47, 57

Grenzmann, Ludger 88

Grieger, Rudolf 45-47, 55, 58-59

Grimm, Heinrich 27

Guarino of Verona 27, 174

Guitman, Barnabás 10, 101-102

Gullano, Giuseppe 90

Guthmüller, Bodo 80

\section{H}

Hadrian (emperor) 85

Hadrianus of Vilhartice see Vilhartice, Hadrianus of

Haimo of Halberstadt 47

Haller, Wilhelm (IV) 131

Han, Nicolaus 19

Hankins, James 98

Hapák, József 133
Harder, Hans Bernd 59, 140-141, 154, 156, 189, 191, 194

Hartfelder, Karl 19, 188

Hasištejnský z Lobkovic, Bohuslav (Bohuslaus Hassenstein-Lobkowitz / Bohuslaw Hassenstein von Lobkowicz (Lobkowitz) 7, 41, 46, 51, 58-59, 66-67, 69-70, 74, 79, $90,102,109,113,187,191$

Haye, Thomas 88

Heiligmaier, Wolfgang 141, 191

Heimburg, Gregor 62-63, 78

Heitzmann, Christian 121

Hejnic, Josef 101, 139, 142, 145-146, 185

Helmrath, Johannes 83

Hercules 76, 88, 144, 170-171, 176

Herding, Otto 89

Hermann, Hermann Julius 122, 128

Hesiod 87

Hess, Andreas 118

Hevesy, André de 130

Hewen, Wolfgang de (Wolfgangus Hebenensis) 39

Hieronymus see Jerome

Hippocrates 85

Hlaváček, Petr 51, 55, 57-58, 189

Hlobil, Ivo 10, 45, 48, 49, 51-52, 55, 58, 101, 139-142, 151, 153-154, 186, 189-190

Hodějovský of Hodějov, John 142, 145

Hoffmann, Edith 48, 56, 133, 190

Hoffmann, Friedhelm 149-150, 188

Hohenlohe, Sigmund von 38

Holborn, Annemarie 89

Holborn, Hajo 89

Holl, Lienhart 19

Holotík, Ludovít 46, 154

Homer 28, 142-143, 167, 172

Horace 93, 96, 97, 143, 146, 164

Horváth, László 101, 185

Horváth, Richárd 10, 159, 190

Hörsch, Markus 51

Hrabanus Maurus 64

Hrdina, Karel 101, 185

Hunoldus of Roermond 83

Hunyadi family 130

Hus, John 19

Huszti, József 116

Hutten, Ulrich von 27-28, 36, 190

Hýbl, František 52, 189, 192

I

Iob, Leonardus 116

Isidor of Seville 72, 88, 167, 178 
Isocrates 120, 122, 133, 169

Ittzés, Máté 109

\section{J}

Jakob II von Baden see Badensis, Jacobus

Jakubec, Ondřej 51, 190

Janál, Rudolf 140, 190

Janus Pannonius 45, 51, 63, 74-76, 161, 174

Jaworski, Tomasz 168

Jerome 104

Joachimsohn, Paul 78-79

Johannes de Zredna 47, 49-51, 62-63, 117-121, 123-124, 127, 130-133, 135, 137-138, 188, 190

Johannes Rabensteinensis see Rabensteinensis, Johannes

John the Evangelist 116

Juhász, László 7

Jupiter 51, 87, 89, 91, 144, 210

Just, Jiří 10

Justinian 167

Juvenal 76, 81

K

Kalhous, David 152, 190

Kalmár, János 158

Kalous, Antonín 10, 45, 48, 52, 54, 58, 79, 190

Kalousek, Josef 46

Kaňák, Miloslav 46

Kapistrán, Jan see Capistran, St John

Karl V see Charles V

Kaster, Robert A. 98

Kasza, Péter 10, 190

Kecskeméti, Gábor 4, 8-9

Keil, Heinrich 86

Kesserü, Mihály (Michael Chesserius) 38, 41

Kibre, Pearl 32, 34-35, 37

King Matthias see Matthias Corvinus

Kipf, Johannes Klaus 61, 64-65, 190

Kirkham, Victoria 77, 188

Kiss, Farkas Gábor 3-5, 10, 16, 77, 101, 107, 190, 215-216

Kittel, Balthasar 31

Kitzscher, Johannes von 39

Klaniczay, Tibor 7, 9, 66, 69, 75, 116-117, 190191

Klatovský, Šimon Ennius see Ennius Klatovský, Šimon

Klecker, Elisabeth 13-14, 24, 189, 191

Knod, Gustav C. 39-40

Kohout, Štěpán 10

Kolářová, Jana 6, 139, 216
Kollar, Adam Franz 157

Kolmanová, Simona 10

Kopernikus, Nikolaus see Copernicus, Nicolaus

Koquovicki, Johannes 39

Koroknay, Éva 120-121, 127, 132

Korvín, Matyáš see Matthias Corvinus

Kostowski, Jakub 55

Kovács, Endre 7

Kovács, Eszter 10

Kowalska-Urbankowa, Zofia 157, 162

Koźuszek, Waldemar 168

Körmendy, Kinga 56

Krachenberg, Johannes 11, 14

Krafft, Karl 83

Králík, Oldřich 140-141, 191

Kramer, Johannes 19

Krautter, Konrad 39

Křenková, Zuzana 55, 191

Kristeller, Paul Oskar 64, 186

Kronos see Saturn

Kronthal, Berthold 65, 191

Krumlow, Alexander von 40

Krumlow, Martin von 40

Kubes, Jiř́i 10

Kunovic, Jan z 49, 52-53, 189

Kühorn, Johannes see Forderer, Johannes

L

Ladislas II see Vladislav II

Ladislaus V Postumus (king of Hungary) 62

Laelius 4, 77, 84, 93-95, 208

Landino, Cristoforo 72

Landis da Capodistria, Pietro de 42

Lang, Vincenz (Eleutherius Longinus) 39

Lang, Wolfgang 21

Langer von Bolkenhain, Johannes 64, 190

Lantsch, Georg 21

Lapis, Dominicus de 19

Lasco, Johannes a 180

Lazzarelli, Ludovico 64

Leiner, Wolfgang 64, 191

Lern, Wolfgang 167, 181

Livy 82, 167

Lobkowicz (Lobkowitz), Bohuslaw Hassenstein von see Hasištejnský z Lobkovic, Bohuslav

Locher, Jakob 31, 39

Logus, Georgius 141, 143, 145-146

Louis I (king of Hungary) 56

Louis II (king of Hungary) 113

Lucan 29, 127, 164, 167, 177, 193 
Ludwig II see Louis II

Luna 89, 175

Lupulus Bodmanensis, Johannes see Wölfflin von Bodman, Johann

Luther, Martin 36

\section{M}

Macek, Josef 45

Machilek, Franz 52, 140, 154, 191

Macrobius 85, 87, 91, 98

Macůrek, Josef 46, 51, 153-154, 191

Maecenas 144, 146

Maggi, Armando 77, 188

Maisel, Thomas 14, 189

Malagola, Carlo 32-34, 36, 38, 40, 42

Manfredus, Hieronymus 19

Marbod von Rennes see Marbodus Redonensis

Marbodus Redonensis 25

Marek, Jindřich 10

Mareş, Elizabeth 40

Mareş, Martin 40-41

Marosi, Ernő 9, 191

Marrasio, Giovanni 72

Mars 91, 98, 164

Martial 173

Martianus Capella 139

Martínek, Jan 67, 69-70, 101-102, 139, 142, 145, 184-186, 191

Martínková, Dana 7, 50, 67, 102, 184-185, 191-192

Mary Magdalene 65, 84

Mary see Virgin Mary

Mat'a, Petr 9

Mathusalem 53

Matthias Corvinus, king of Hungary 5, 18, 22-23, 29, 45, 47-48, 50, 52, 56, 62, 65, 79-80, 113-120, 122-124, 126-128, 130131, 133, 135-136, 138, 188-192

Mátyás király see Matthias Corvinus

Maximilian I (emperor) 15-17, 24, 27, 39, 84, $146,161,186$

Mazal, Otto 122

Mazurkiewicz, Roman 10, 101-102

Mela, Pomponius 81

Menander 87

Menna, Mirko 108

Mercury (Mercurius) 15, 17, 28, 91, 172, 175

Mersich, Brigitte 122

Měštánek, Tomáš 54, 192

Miggiano, Gabriella 157, 162, 192

Migne, Jacques-Paul 48

Mikó, Árpád 9-10, 48, 101, 114, 128, 133, 186, 192
Milius (Aemilius), Iulius 11, 13

Miodońska, Barbara 57

Mitsiou, Ekaterini 117

Molorchus 171

Monfasani, John 10, 101, 117-119

Monok, István 9-10, 190, 192

Moravy, Pavel z 54

Moser, Michael 10, 101

Moses 89, 178

Mraz, Joannes (Jan XI Mráz/Mrazo) 165-166

Murawiec, Wiesław F 57

Mureşan, Dan Joan 117

Murmellius, Johannes 83

Murrho, Sebastian 28, 114, 138

Muses 15, 17, 21, 24, 27-28, 74, 170, 172-173

Mutianus Rufus, Conradus 89-90

Müller, Gernot Michael 13, 192

Münzer (Monetarius), Stephen (Cremnicensis) 180

N

Nausicaa 28

Nazianzenus, Gregorius 116

Nechutová, Jana 156, 184

Negri, Francesco see Niger, Franciscus

Neideck, Georg von see Neydecker, Georgius

Neithart Fuchs (Neidhart the Fox) 16

Nešpor, Václav 153, 192

Neumann, Tibor 10, 190

Neuß, Heinrich von 39

Neydecker, Georgius (Georg von Neideck) 11

Niederkorn-Bruck, Meta 14

Niger, Franciscus 80, 86, 107, 113, 190

Nitsch, Gregor 21-22

Novaković, Darko 89

Noviforensis, Johannes 154

Noviomagensis, Henricus Joannes 39

O

Odofred 36

Odysseus see Ulysses

Olahus, Nicolaus 157, 162

Oleśnicki, Zbigniew 88-89

Origen 47

Orosius, Paulus 167, 178

Orpheus 87, 98, 175

Oseuen, Henricus (Heinrich/Henryk Oswein/ Oseven) 65-68, 101-103, 185

Ostrowski, Stanisław 39

Osvaldus de Hungaria (Osvaldo de Ungheria) 41-42

Oswein/Oseven, Heinrich see Oseuen, Henricus 
Otmar, Iohannes 15

Ovid 37, 71, 75, 79, 97, 167, 171-173, 175, 181

\section{$\mathbf{P}$}

Pajorin, Klára 69, 102, 157, 185

Pallas Athene 91, 146, 164

Pannonius, Janus see Janus Pannonius

Pantz, A von 55

Papp, Judit 9, 190

Parrhasius 176

Paul II (pope) 117

Pavlovský, Stanislaus 51

Perotti, Niccolò 117

Perůtka, Marek 190

Petrarch 31, 77-78, 85, 91, 188, 193

Petronius 87

Petrů, Eduard 101, 139-142, 144, 151, 153-154, $186,189,192$

Peuerbach, Georg 63, 122, 127

Peutinger, Konrad 36, 39

Pfändtner, Karl-Georg 122, 126

Pfarrer von Kahlenberg 16

Phaedrus 84

Phaëton 89

Philippus cosmographus 13

Phoebus 12, 15, 17, 24, 142, 146, 163, 172, 175176,178

Piana, Celestino 41-42

Picardus, Barnabas 19

Piccolomini, Eneas Silvius 62, 72, 74, 88-89

Pico della Mirandola, Giovanni Francesco 39

Pietro Lombardi, Paola di 136

Pilnáček, Josef 53

Pini, Antonio I. 33, 36-37

Pinifer (Beck), Erasmus 11

Pirozyński, Jan 154, 191

Pisciculus (Fischer), Andreas 141

Pišna, Jan 10

Plaisant, Maria Luisa 88-89

Plato 12, 18, 76, 84, 87, 91, 94, 98, 115-118, 138

Plautus 82, 170

Pliny the Elder 39, 81-82, 139, 164, 170, 176

Pliny the Younger 111, 138

Plutarch 51

Pócs, Dániel 115, 124, 138

Poggio see Bracciolini, Poggio

Polich von Mellerstadt, Martin 90

Polišenský, Josef 50, 192

Poliziano, Angelo 38

Pompeius Trogus 82

Pop, Ioan-Aurel 117

Popović, Mihailo 117

Potuček, Augustin 7, 70, 187
Prasek, Vincenc 153, 192

Praxiteles 176

Pražak, Richard 7

Preiser-Kapeller, Johannes 117

Prix, Dalibor 51

Propertius 81, 108-110, 164, 173

Proserpine 89

Prostějov, Filip of 54-55

Prostějov, Mikuláš of 54

Proxenus a Sudetis, Simon 7

Ptolemaeus, Claudius 18-23, 120, 122, 128129, 206

Pumprla, Václav 52, 192

Puppi, Lionello 84

Pythagoras 47

Q

Quinqueecclesiis, Osvaldo de see Osvaldus de Hungaria

Quintilian 103-104, 111, 167, 178

R

Raabe, Paul 66, 191

Rabensteinensis, Johannes 7

Rack, Johannes (Johannes Rhagius Aesticampianus) 39

Rad, Ludwig 62

Rädle, Fidel 90

Ranatinus, Georgius 141

Rangoni, Gabriel 51

Ransanus, Petrus 49, 57

Reger, Iohannes 19

Regiomontanus, Johannes 118, 120-124, 126131, 133, 135

Réthelyi, Orsolya 114

Rhagius Aesticampianus, Johannes see Rack, Johannes

Rhenanus, Beatus see Beatus Rhenanus

Ricci, Milena 136

Richter, Franciscus Xaverius 69, 151, 166, 184

Rill, Gerhard 58

Rippur, Reinhard von 21

Ritoók-Szalay, Ágnes 48, 192

Robert, Jörg 14, 87, 192

Robin, Diana 107

Rose, Anna 5, 31, 35-37, 108-109, 216

Rosenberg, Nicolaus von 161-162

Rosenberg, Peter von (Petr z Rožmberka) 109

Rosenberg, Ulrich von (Oldřich z Rožmberka, Ulrichus de Rosis) 40-41, 79, 109-110

Rosenberger, Iohannes 12, 19

Rosselli, Francesco 120-121, 124, 126-128, 133, 135 
Rotenhan, Sebastianus a 39

Roth, Johannes 5, 59, 61-68, 78-79, 102-103, $105,187,193-194$

Rothe, Hans 59, 140-141, 154, 156, 189, 191, 194

Rothkegel, Martin 46, 59, 140-146, 166, 186, 192-193

Rovného, Václav z 40-41

Rožmberka, Oldřich z see Rosenberg, Ulrich

Rožmberka, Petr z see Rosenberg, Peter von

Rozsondai, Marianne 136

Rösslerová, Magda 156, 184

Rubrius 82

Rufus, Conradus Mutianus see Mutianus Rufus, Conradus

Rupprich, Hans 11-16, 18, 21-22, 102, 157, 163, 184, 188

Rüdesheim, Rudolf von 62

Ryba, Bohumil 7, 40, 53, 78-79, 193

\section{S}

Sabellico, Marcantonio 14, 83

Sallust 82

Salutati, Coluccio 88

Sambucus, Joannes 58

Samek, Bohumil 48, 53, 55

Sannig, Bernard 49

Santritter, Johannes Lucilius 80, 83, 86, 110, 184

Saturn (Kronos) 21, 87-88, 209

Scarperia, Jacobus Angelus de 122

Schäfer, Eckart 23, 96, 188

Schedel, Hartmann 19

Schedel, Hermann 63

Schellenberg, Johannes 113

Schirrmeister, Albert 83, 193

Schlechta, Iohannes (Jan Šlechta ze V̌̌ehrd) $11,13,19,22,51,66-67,69,74,76,113$, 139

Schleinitz, Ernst de see Sleinic, Arnošt

Schlelein, Stefan 83

Schulz, Jindřich 151, 193

Schürer, Matthias 28, 115

Schwenter, Pangratz see Bernhaupt (Schwenter), Pangratz

Scipio (Stäber), Bartholomeus 11

Scipio, Publius Cornelius Africanus 26-27, 184

Scudieri, Magnolia 115

Selden, John 22

Šembera, Alois Vojtěch 79

Semele 144

Seneca the Younger 76, 85, 104
Seznec, Jean 89

Sibutus, Georgius (Daripinus) 140, 191

Sibutus, Georgius 140, 191

Siculo, Grifo 72

Silius Italicus 167

Silvani, Paolo 33-36

Šimek, Frantíšek 46

Simon, Alexandru 117

Simoniti, Primož 62, 194

Simor, János 56

Sinapinus, Martin 21-22, 141

Singrenius, Johannes see Singriener, Johann

Singriener, Johann 25-26, 28-29, 166, 183

Skála of Doubravka, John see Dubravius, Johannes

Škunca, Stanislaus 89

Šlechta of Všehrdy, Jan see Schlechta, Iohannes

Sleinic, Arnošt (Ernst de Schleinitz) 41

Šmahel, František 47, 50, 58, 152, 190, 192-193

Šmeral, Jiří 48, 190

Smrcz, Ádám 5, 93, 216

Socrates 174

Sol (Sun) 89

Sola, Joseph Nicola 89

Solfa, Johannes Benedicti 168

Solinus 164

Solomon, Jon 77, 187

Soltész, Zoltánné (Elisabeth) 56

Sorbelli, Albano 31-32

Sottili, Agostino 61-62, 78, 193

Soukup, Pavel 152, 190

Spekner, Enikő 115124

Spieß, Heinrich see Cuspidius, Henricus

St Catherine 35

St Martin 35

St Nicolaus 35

St Francis 49

Stäber, Bartholomeus see Scipio, Bartholomeus

Stabius, Johannes 11

Statius, Publius Papinius 81, 167, 172, 177

Stäuble, Antonio 88

Steffen, Walter 32-33, 36

Stein, Eitelwolf vom 39

Stein, Marquardus vom 39

Stemler, Ágnes 66, 185

Stiborius, Andreas see Ctiborius, Andreas

Stieröxel, Stephan see Taurinus, Stephanus

Storchová, Lucie 6, 142, 145-146, 149, 151, 193, 216

Strnad, Alfred A 154, 191, 194

Struever, Nancy 77, 193

Stuchs, Georg 19 
Studničková, Milada 10, 57

Sturlinius Smalcaldia (Sturnus, Iohannes) 11, 74

Sturnus, Johannes see Sturlinius Smalcaldia

Suetonius 108-109, 111

Sulpicius 111

Svatoš, Martin 10

Svoboda, Karel 61, 78, 84, 85, 94, 103, 157, 184, 193

Swola, Iohannes de 21

$\mathrm{Sz}$

Szalontai, Barnabás 158

Száraz, Orsolya 9, 190

Szeder-Niemann, Monika 113

Szemerei, Péter 9

Szende, Katalin 124

Szilágyi, Emőke Rita 5, 61, 101-103, 216

Szovák, Kornél 10

Szörényi, László 29, 193

Szydłowiecki, Paweł 39

\section{T}

Tacitus, Cornelius 16, 18, 82, 155

Tacuinus, Iohannes 15, 81, 184

Takács, Imre 133

Takács, László 10

Tangl, Karlmann 61, 193

Tannstetter, Georg see Collimitius, Georg Tannstetter

Taurinus, Stephanus (Stierochs, Stieröxel) 7, 26, 29, 140-141, 186, 193-194

Tegyey, Imre 69, 102, 157, 185

Teichmann, Lucius 57

Tertullian 139, 164

Themistocles 111

Theogenes 82

Thetis 98

Thomas Aquinas 47

Thuróczi, János 50

Thurzo (Thurzó), Alexius 143

Thurzo (Thurzó), Johannes 27, 29, 53, 140, 142-143

Thurzo (Thurzó), Stanislaus 6, 22, 46, 50-51, 53, 59, 139-147, 152-155, 166, 186-187, $190,193-194$

Tibull 167, 175, 178

Timaeus 84

Tiresias 88, 210

Toldy, Ferenc 47

Tolhopf, Johannes see Tolophus, Johannes

Tolophus (Tolhopf), Johannes 11

Tomasini, Giacomo Filippo 107
Tomicki, Piotr 39

Tortellius, Johannes 82

Tournoy, Gilbert 52

Tovačovský z Cimburka, Ctibor 51-52

Török, Gyöngyi 56

Trapezuntius, Georgius 76, 118-119, 120-121, $123,128-129,131-133$

Trebizond, Georg of see Trapezuntius, Georgius

Trombetti Budriesi, Anna Laura 36

Tröster, Johannes 62

Truhlář, Antonín 61, 87, 90, 101, 185

Truhláŕ, Josef 45-47, 53, 58, 109, 168, 194

Tuate, Fileno dalle 38

Tulner, Johannes 167, 181

Turre, Petrus de 19

Tüske, László 4, 9

\section{U}

Ueding, Gert 64, 191

Ullman, Berthold Louis 88

Ulsenius, Theodoricus (Dietrich) 11

Ulysses 28

Ungler, Florian 167, 180-181

Ursinus Velius, Caspar 141-146

\section{V}

Vaculínová, Marta 9-10, 70, 101, 187

Vadianus, Joachim 24, 26-29, 86-87, 187, 193

Vadius, Angelus 19

Valerius Flaccus 164, 172, 179

Valla, Giorgio 14

Valla, Lorenzo 62-63

Vantuch, Anton 46, 154

Váradi, Péter 37-38, 41, 194

Várdai, Ferenc 38

Varro, Marcus Terentius 111

Vartemberka, Jan z see Wartenberg, Johannes von

Vartemberka, Ladislav z see Wartenberg, Wladislaw von

Véber, János 10, 194

Végh, András 80, 115, 124, 188

Veitmíle, Krištof see Weitmühl, Christophorus de

Venus 21, 88

Verő, Mária 114

Vietor, Hieronymus 25-28, 166, 183-184

Vilém II of Pernstein 46, 49

Vilhartice, Hadrianus of 141

Vilhartice, Wenceslaus of 141

Vincentino, Augustino 19 
Virgil 47, 97, 142, 144, 167

Virgin Mary 64, 89

Vischer, Peter the Younger 10, 87-88

Vitéz, János (Johannes) see Johannes de Zredna

Vladislav II (king of Bohemia and Hungary) 19, 46-47, 62, 66, 69, 89-90, 109, 113-114, $163,165,168,184,186,194$

Vlnas, Vít 49, 187

Vogel, Klaus A. 62, 193

Vorel, Jaroslav 153, 194

Vrbková, Stanislava 140, 192

Vulcanius Olomutius, Valentinus (Valentin Schmidt or Kovář, called Vulcanius) 53

Vulcanus 181

Vyskočil, Jan K. 57

\section{W}

Waitmyl (Weitmühl), Christoforus de see Weitmühl, Christophorus von

Wakounig, Marija 62, 194

Wartenberg, Johannes von (Jan z Vartemberka) 40-41

Wartenberg, Sigmund von 40

Wartenberg, Wladislaw von (Ladislav z Vartemberka) 40

Watt, Joachim von see Vadianus, Joachim

Wehli, Tünde 133

Weidmann, Konrad 14

Weitmühl, Benedictus 41

Weitmühl, Christophorus von 11, 41

Wels, Volhard 90

Wenceslai de Olmucz, Walentinus (=Vulcanius, Valentinus?) 53

Wendt, Heinrich 65, 191

Werthern, Dietericus a 39

Wimpfeling, Jakob 31

Wimpina, Konrad 90
Winterburg, Iohannes 12

Wladislaus II see Vladislav II

Wolff, Thomas der Jüngere 39

Wolfgangus Hebenensis see Hewen, Wolfgang de

Wolkan, Rudolf 89

Worstbrock, Franz Josef 11, 26, 61, 63-65, 78, 87, 91, 101, 183-185, 190, 191-194

Wotke, Karl 140-141, 152-153, 157-159, 167168, 186, 194

Wölfflin von Bodman, Johann (Johannes Lupulus Bodmanensis) 180

Wörster, Peter 45, 59, 140-141, 154-156, 166, 186, 194

$X$

Xenophon 136

Y

Yun, Bee 149-150, 188

Z

Zaborowski, Stanisław 180

Zaccaria, Vittorio 77, 194

Zápolya, John 146

Zeman, Herbert 11, 66, 188

Zeuxis 176

Zierotin, Jan of, the Elder 47

Zinner, Ernst 118, 122, 124, 126, 128

Zoltán, András 10

Zvole, Johannes of 141

Žytek, Jakub 10

Zs

Zsupán, Edina 5, 113, 118, 121, 129, 136, 215216 


\section{ILLUSTRATIONS}

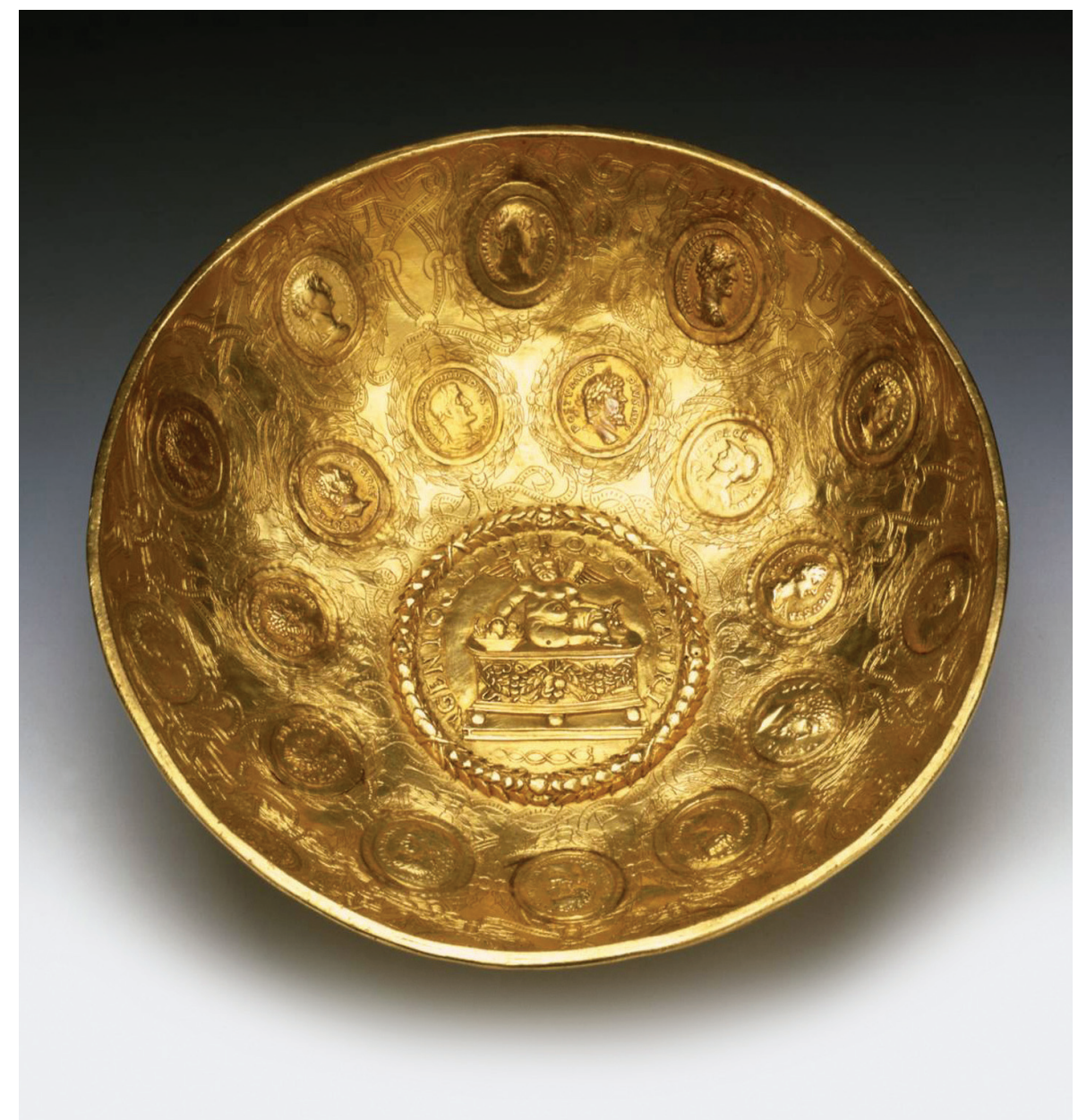

Augustinus Moravus's golden bowl.

Staatliche Kunstsammlungen, Dresden, Grünes Gewölbe, Inv. Nr. IV/40 


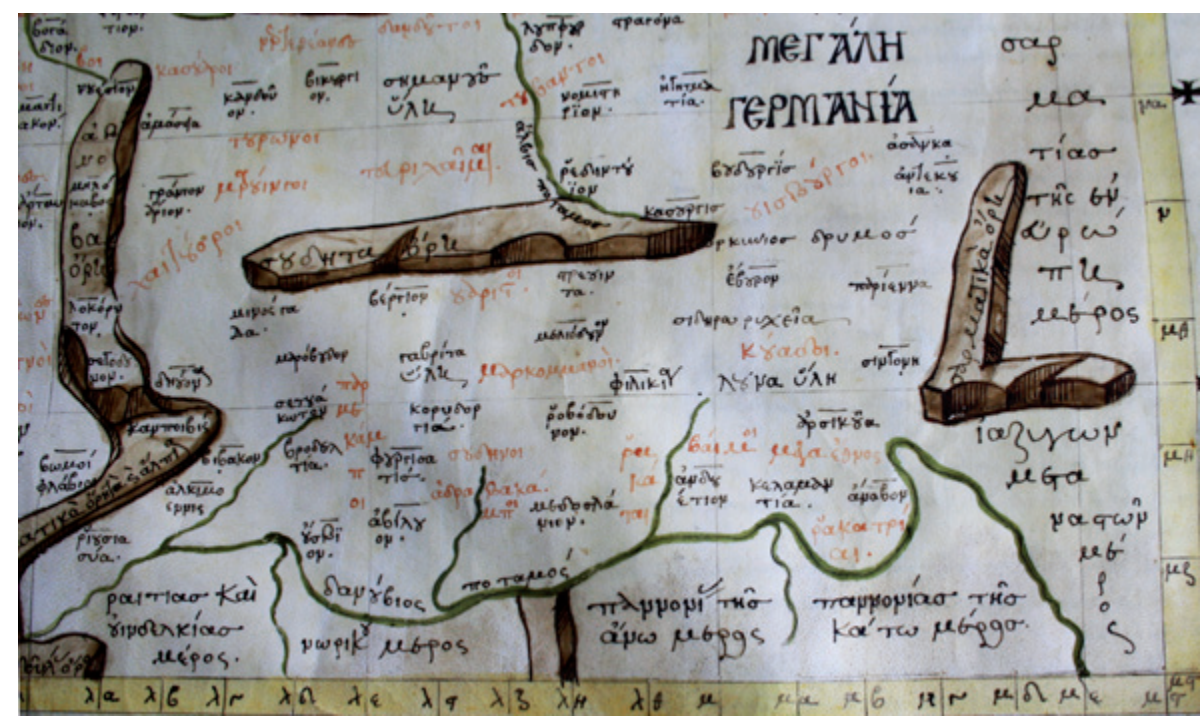

Abb. 3: Baífuot auf der Ptolemaios-Karte der Bibliotheca Corviniana (Wien, ÖNB, Cod. hist. gr. 1 , f. $56^{\text {r) }}$

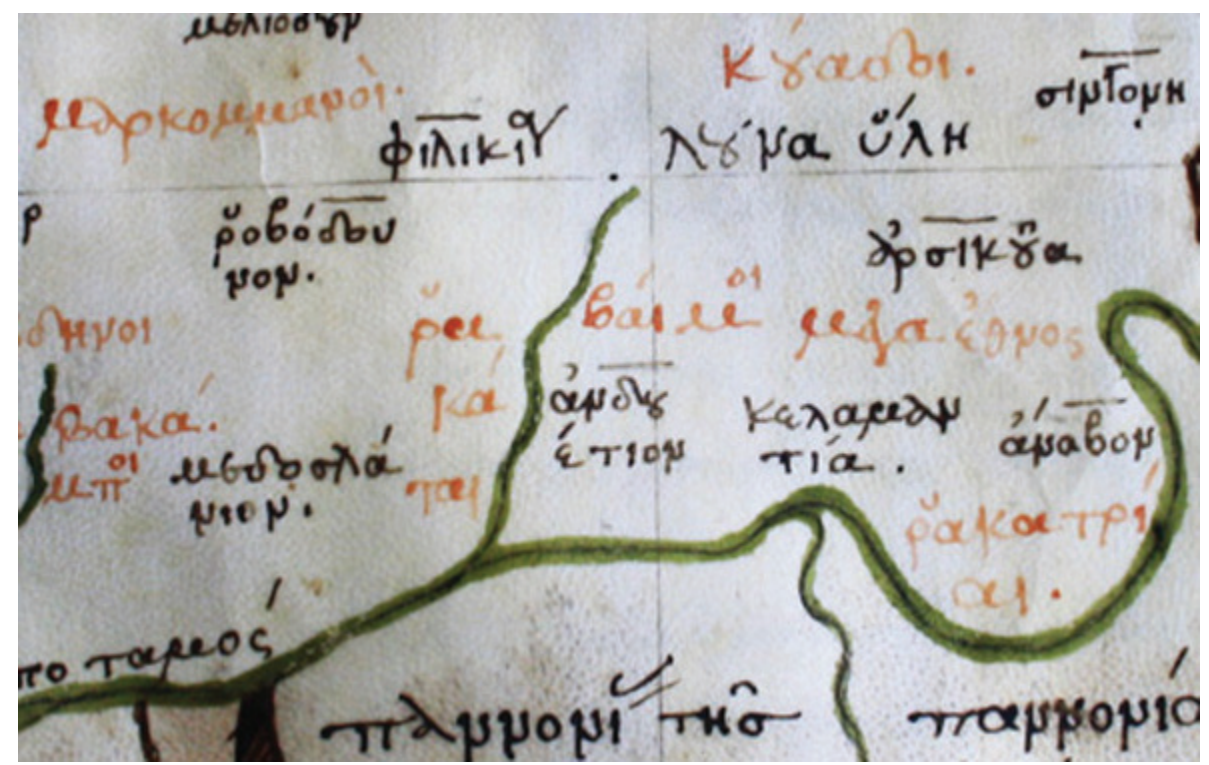

Abb. 4: Detailausschnitt: Baí $\mu$ oı auf der Ptolemaios-Karte der Bibliotheca Corviniana (Wien, ÖNB, Cod. hist. gr. 1, f. 56 ${ }^{\text {r }}$ 


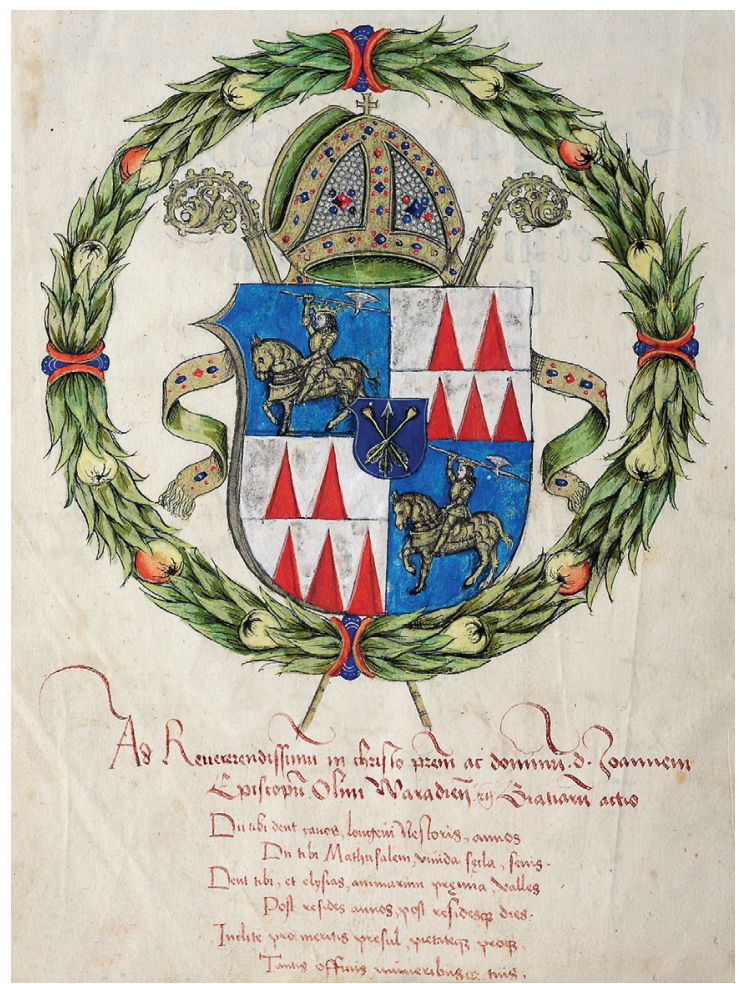

Fig. 2. The panegyric coat-of-arms of Filipec accompanied with an encomium in verses in a book owned by Valentinus Vulcanius in Cracow. (Beroaldo, F., Commentarii in Asinum aureum. 1500. Front flyleaf. Książnica Cieszyńska, Cieszyn [Poland], T III 31.)
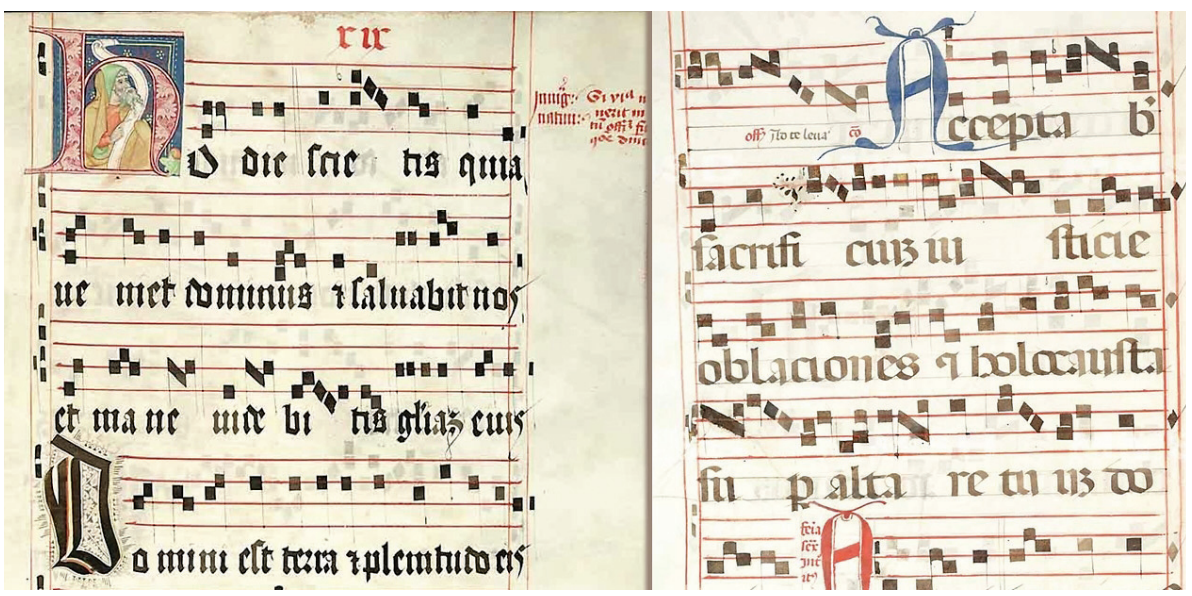

Fig. 3. Graduale pro choro commissioned by Filipec for Franciscans (Research Library in Olomouc, M IV 3). The script gothica formata changes to rotunda and back several times in the volume. 


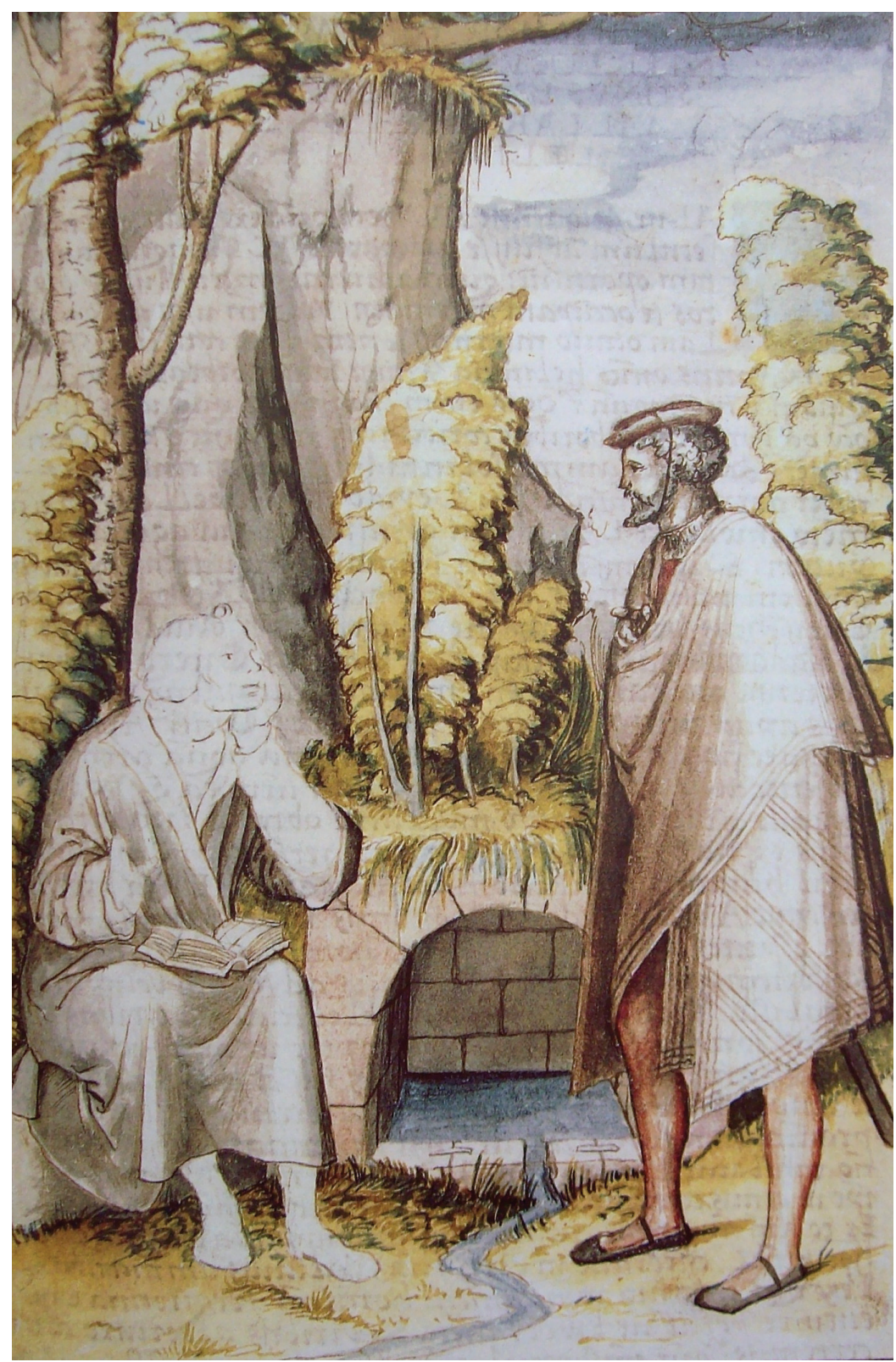

Fig. 1. The meeting of Augustinus (sitting) and Laelius (standing) near Padua. Apologia poetarum, Berlin, St. Bibl., ms. lat. fol. $335,9^{\text {r }}$ 


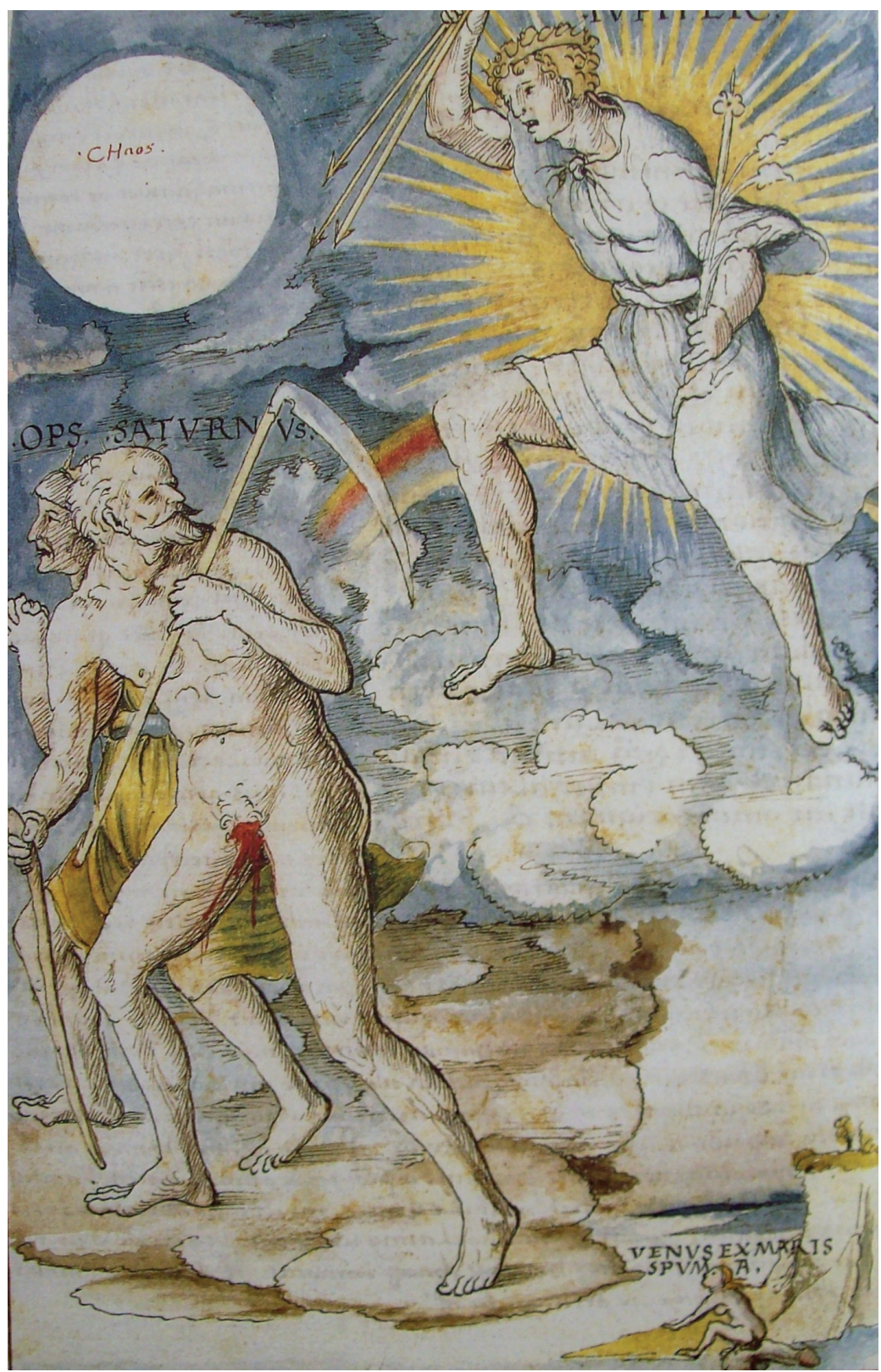

Fig. 2. "Exul Saturnus regnis fugiens arma Iovis".

Apologia poetarum, Berlin, St. Bibl., ms. lat. fol. 335, 15v 


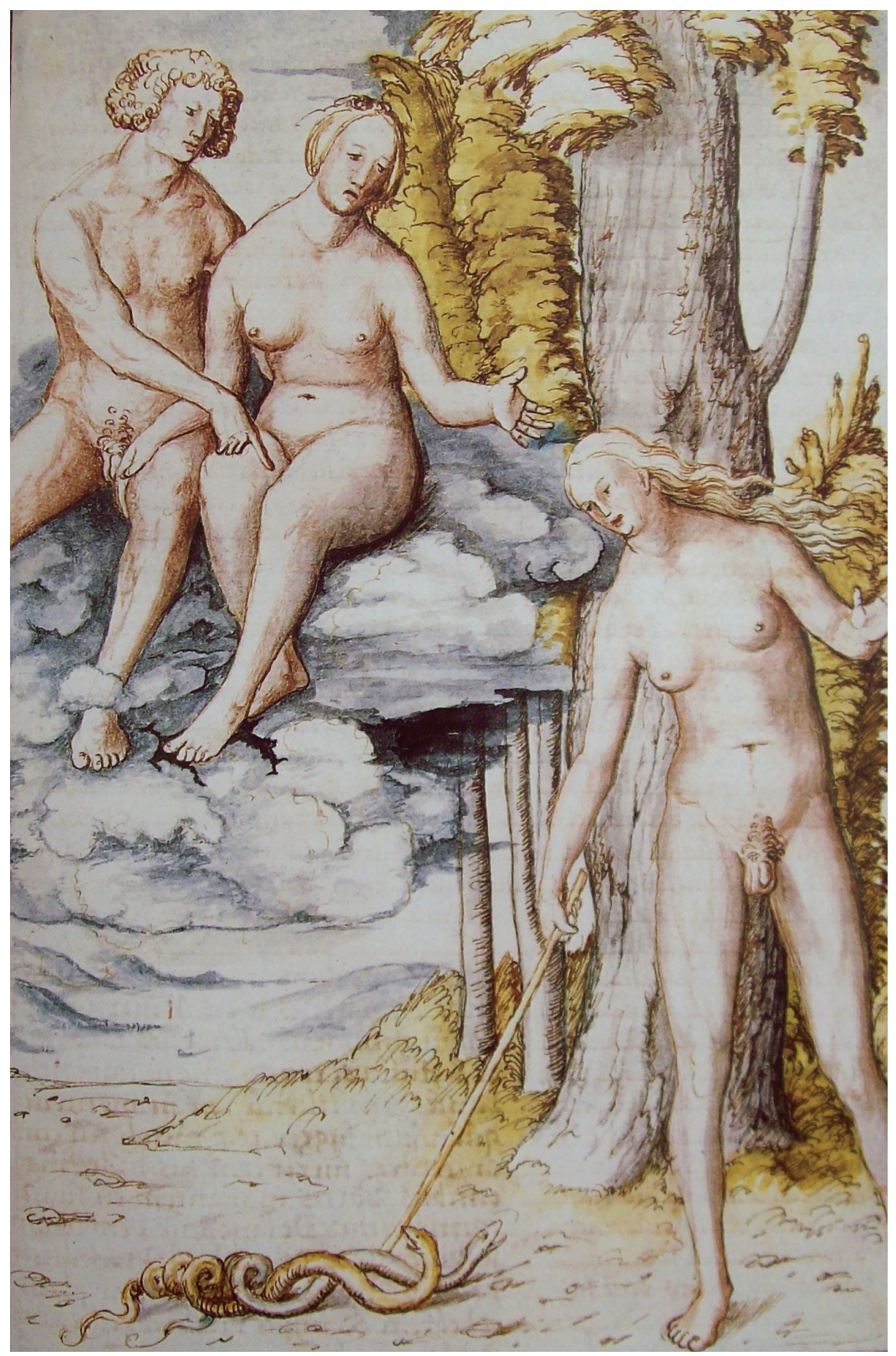

Fig. 3. "Iupiterque Iuno certant Thiresia iudice". Apologia poetarum, Berlin, St. Bibl., ms. lat. fol. 335, $22^{\mathrm{r}}$ 


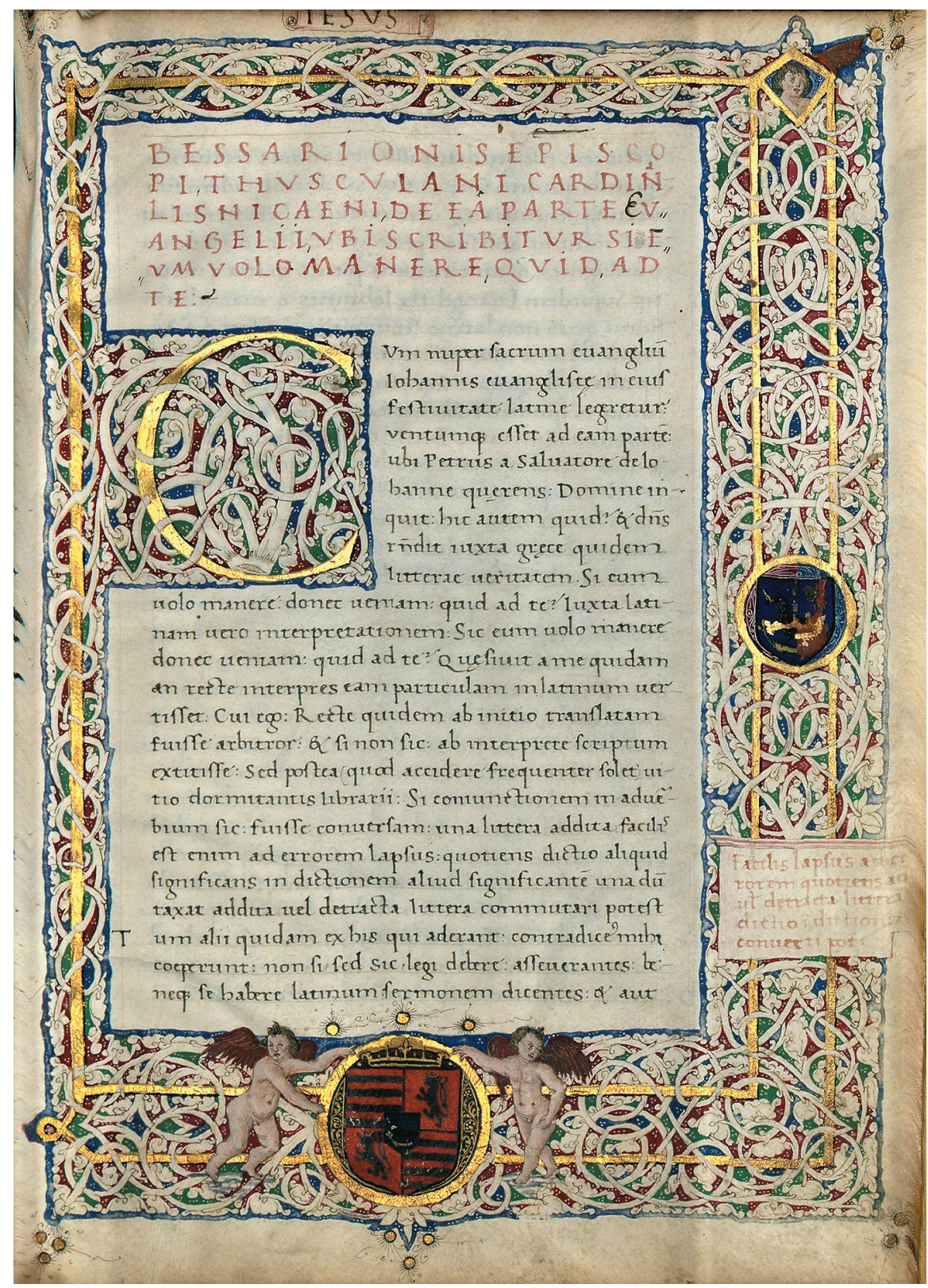

Abb. 1: Budapest, OSZK, Cod. Lat. 438., f. $1^{\mathrm{r}}$ 


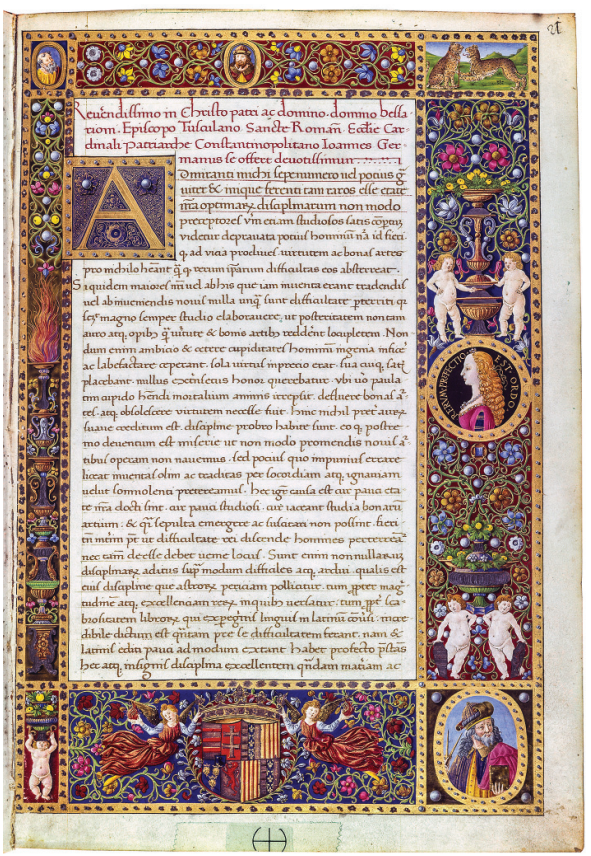

Abb. 2: Wien, ÖNB, Cod. 44, f. $1^{\mathrm{r}}$

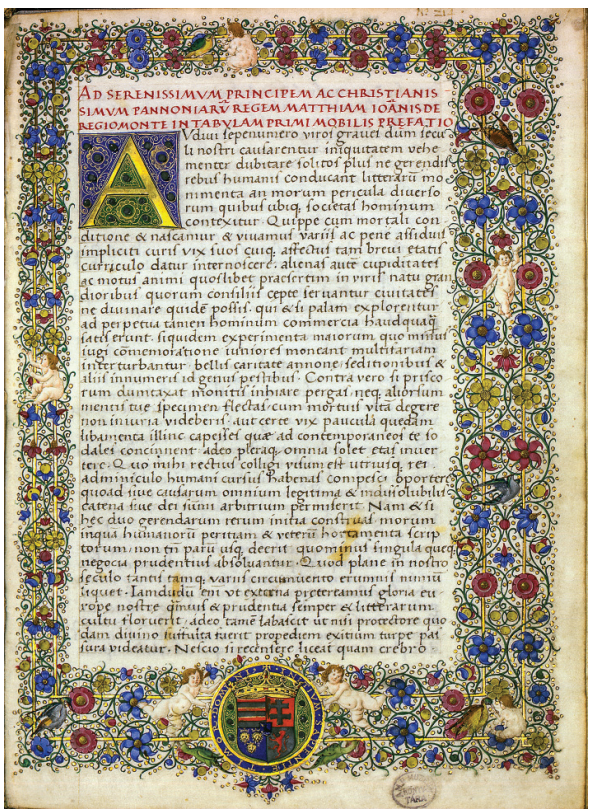

Abb. 4: Budapest, OSZK, Cod. Lat. 412., f. $1^{\mathrm{r}}$

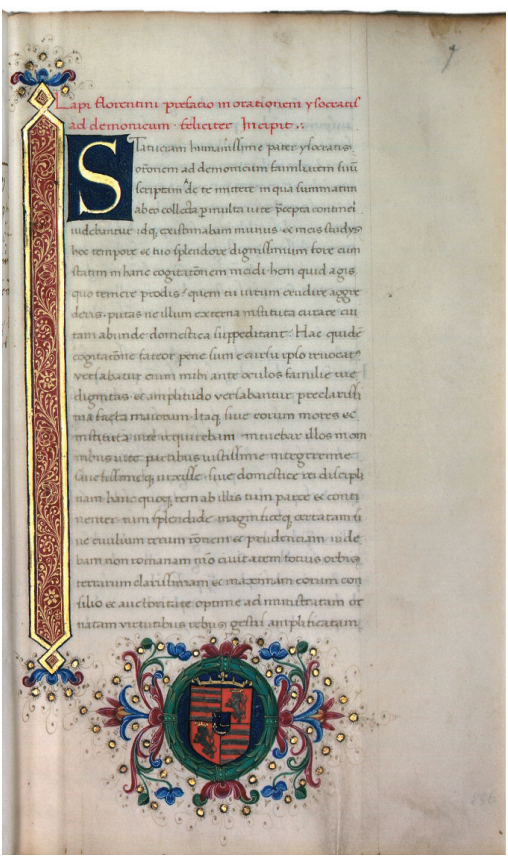

Abb. 3: Budapest, OSZK, Cod. Lat. 430., f. $1^{\mathrm{r}}$

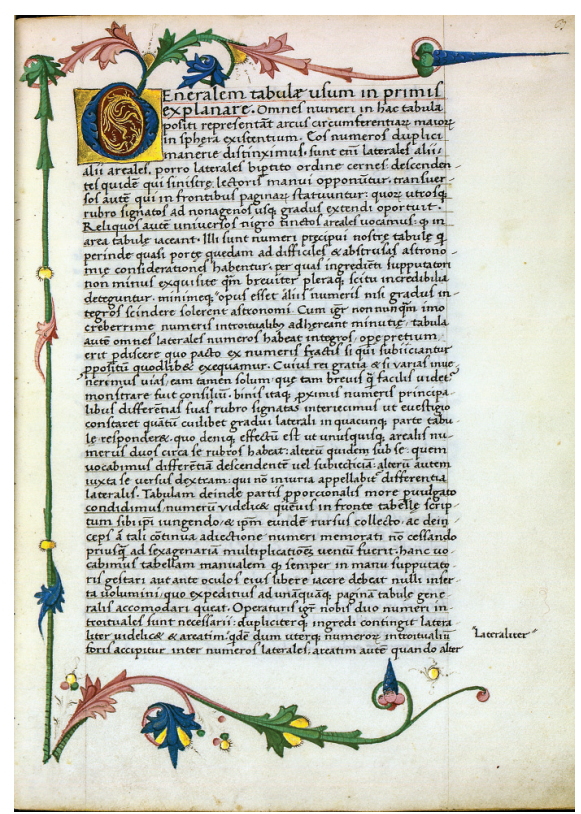

Abb. 5: Budapest, OSZK, Cod. Lat. 412., f. $3^{r}$ 


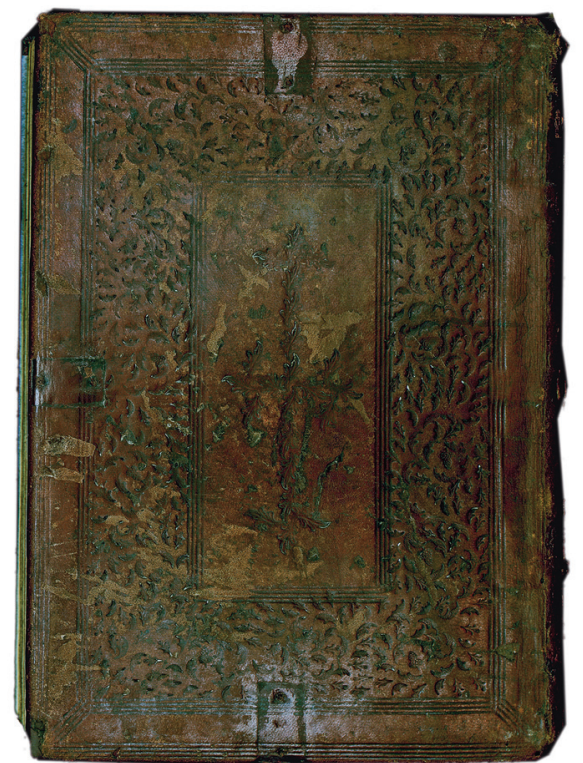

Abb. 6: Budapest, OSZK, Cod. Lat. 412., Hinterdeckel (Gruppe-Egidus?)

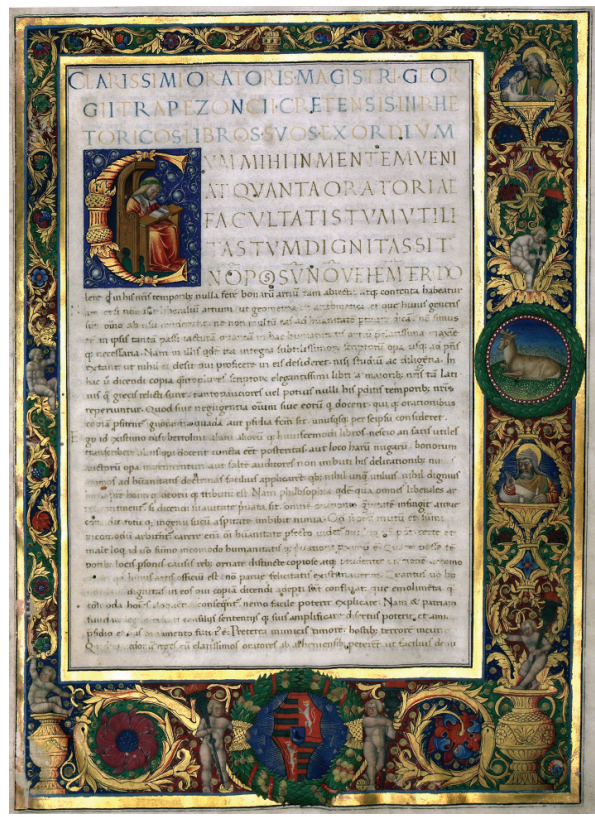

Abb. 8: Budapest, OSZK, Cod. Lat. 281., f. $1^{\text {r }}$

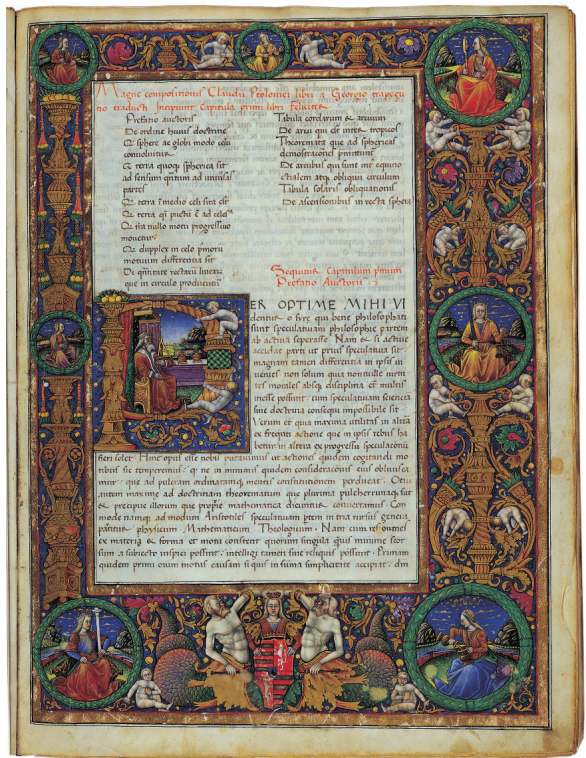

Abb. 7: Wien, ÖNB, Cod. 24, f. $1^{\text {r }}$

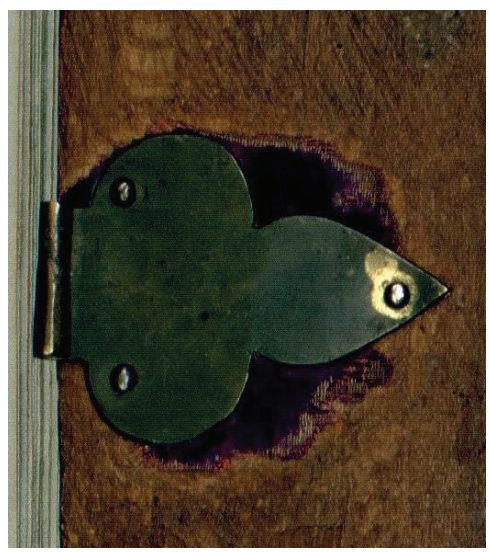

Abb. 9: Budapest, OSZK, Cod. Lat. 281., Hinterdeckel (Detail) 


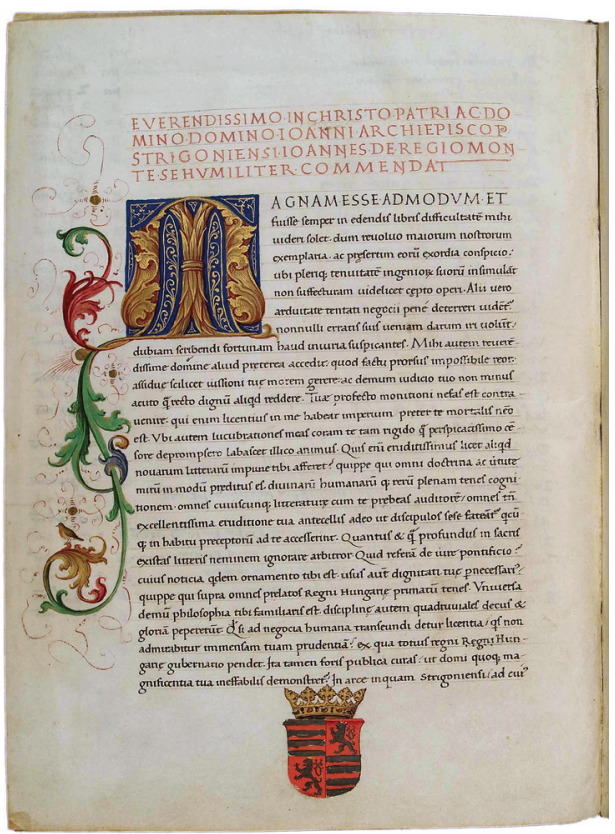

Abb. 10: Wolfenbüttel, HAB, Cod. Guelf. 69.9 Aug. $2^{\circ}$, f. $^{\mathrm{v}}$

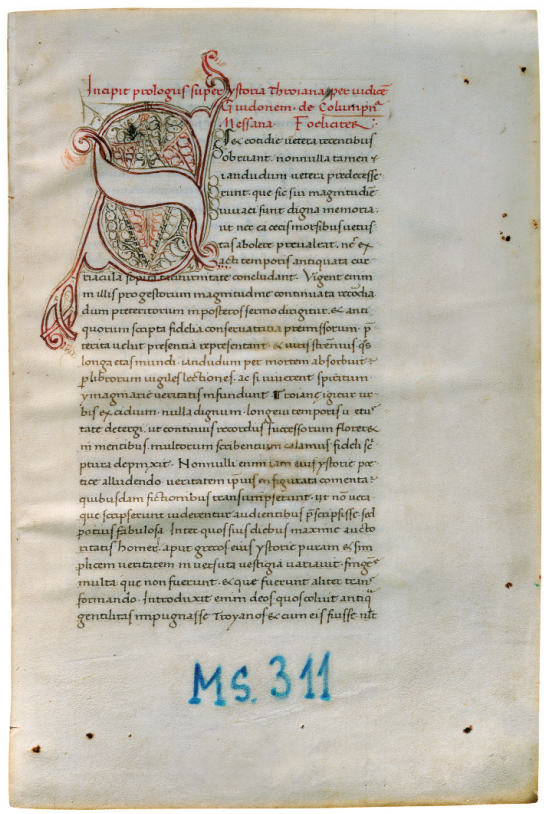

Abb. 12: Kalocsa, Bibliothek der Kathedrale, Ms. 311, f. $1^{\mathrm{r}}$

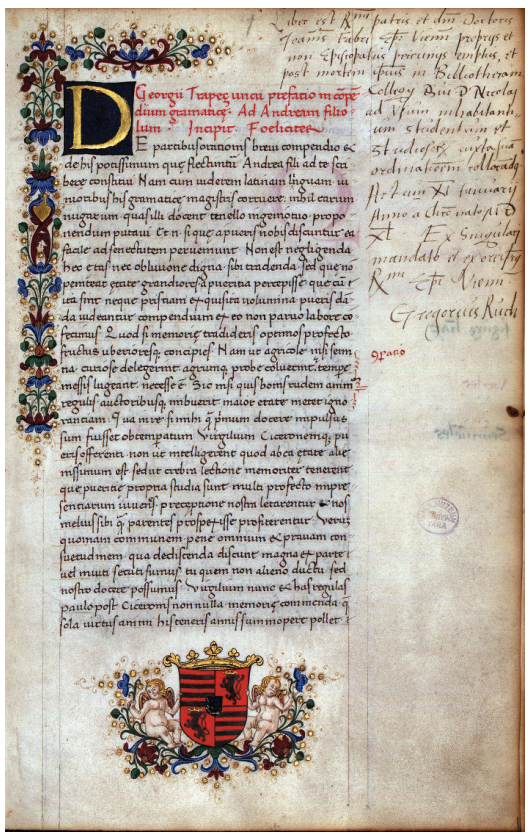

Abb. 11: Budapest, OSZK, Cod. Lat. 428., f. $1^{\mathrm{r}}$

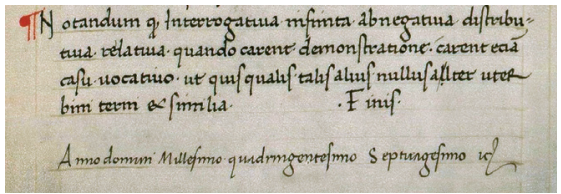

Abb. 13: Budapest, OSZK, Cod. Lat. 428., f. $42^{\mathrm{r}}$ (Detail)

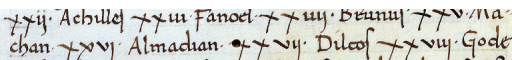

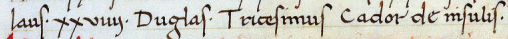
Ditre lubsum feat facts.

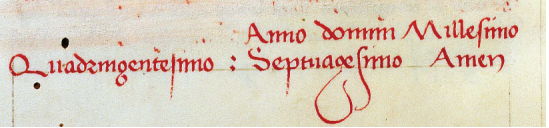

Abb. 14: Kalocsa, Bibliothek der Kathedrale, Ms. 311, f. $167^{\mathrm{v}}$ (Detail) 


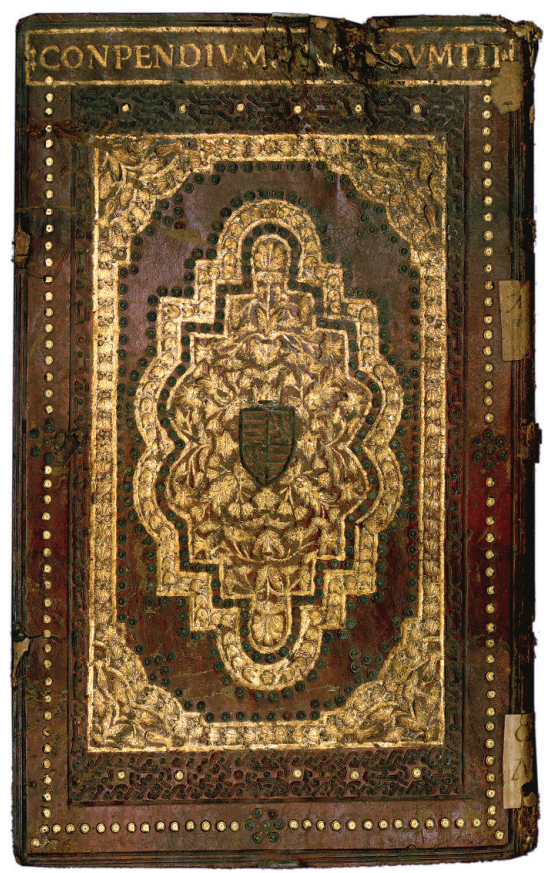

Abb. 15: Budapest, OSZK, Cod. Lat. 428., Hinterdeckel

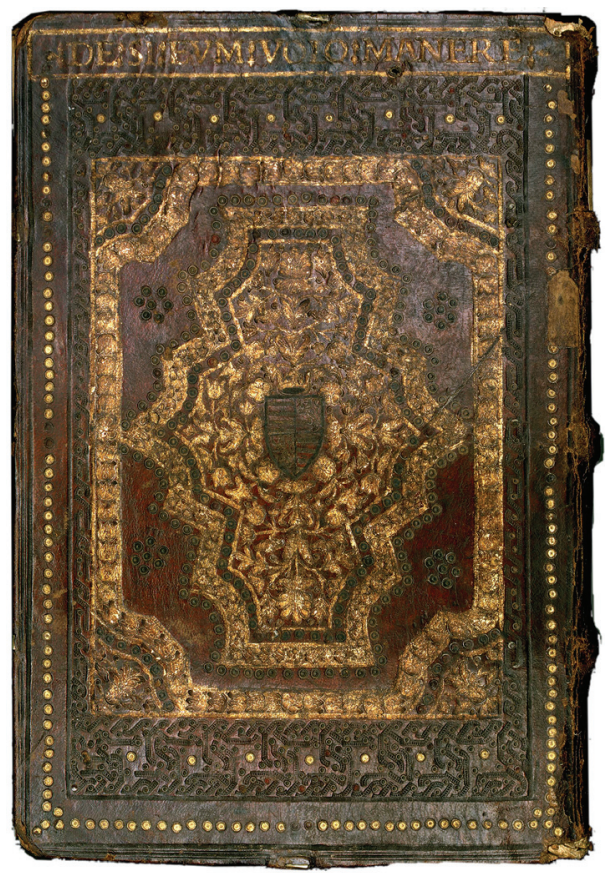

Abb. 16: Budapest, OSZK, Cod. Lat. 438., Hinterdeckel

\section{List of Illustrations}

Augustinus Moravus's golden bowl

Abb. 3-4.

(Christian Gastgeber: Augustinus Moravus und seine Beziehungen zum Wiener Humanistenkreis) . . . . . . . . . . . . . . . . . . . . . 206

Fig. 2-3.

(Matyáš Franciszek Bajger: Discovering Relationships between Jan Filipec and Humanism)

Fig. 1-3.

(Farkas Gábor Kiss: Augustinus Moravus and the Transmission of Ancient Wisdom in the Context of Poetry)

Abb. 1-16.

(Edina Zsupán: Bessarion immer noch in Buda?

Zur Geburt der Bibliotheca Corvina) ... 


\section{AUTHORS AND THEIR AFFILIATIONS}

Matyáš Franciszek Bajger

University of Ostrava, University Library

Ostrava, Czech Republic

Zoltán Csehy

Comenius University in Bratislava

Bratislava, Slovakia

Péter Ekler

National Széchényi Library, Old and Rare Books

Budapest, Hungary

Christian Gastgeber

Österreichische Akademie der Wissenschaften, Institut für Mittelalterforschung,

Abteilung Byzanzforschung

Vienna, Austria

Farkas Gábor Kiss

MTA-ELTE Research Group on Humanism in East Central Europe

Budapest, Hungary

Jana Kolářová

Palacký University

Olomouc, Czech Republic

Anna Rose

Berlin, Germany

Ádám Smrcz

Eötvös Loránd University, doctoral student

Budapest, Hungary

Lucie Storchová

Institute of Philosophy, Academy of Sciences of the Czech Republic

Praha, Czech Republic

Emőke Rita Szilágyi

Institute for Literary Studies, Research Centre for the Humanities, Hungarian

Academy of Sciences

Budapest, Hungary

Edina Zsupán

National Széchényi Library, Head of Department of Academic Affairs

Budapest, Hungary 